NUREG/CR-3408

PNL-4788

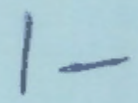

\title{
Organohalogen Products from Chlorination of Cooling Water at Nuclear Power Stations
}

Prepared by R. M. Bean

Pacific Northwest Laboratory

Operated by

Battelle Memorial Institute

Prepared for

U.S. Nuclear Regulatory

Commission 


\section{NOTICE}

This report was prepared as an account of work sponsored by an agency of the United States Government. Neither the United States Government nor any agency thereof, or any of their employees, makes any warranty, expressed or implied, or assumes any legal liability of responsibility for any third party's use, or the results of such use, of any information, apparatus, product or process disclosed in this report, or represents that its use by such third party would not infringe privately owned rights.

\section{Availability of Reference Materials Cited in NRC Publications}

Most documents cited in NRC publications will be available from one of the following sources:

1. The NRC Public Document Room, 1717 H Street, N.W. Washington, DC 20555

2. The NRC/GPO Sales Program, U.S. Nuclear Regulatory Commission, Washington, DC 20555

3. The National Technical Information Service, Springfield, VA 22161

Although the listing that follows represents the majority of documents cited in NRC publications, it is not intended to be exhaustive.

Referenced documents available for inspection and copying for a fee from the NRC Public Document Room include NRC correspondence and ir,ternal NRC memoranda; NRC Office of Inspection and Enforcement bulletins, circulars, information notices, inspection and investigation notices; Licensee Event Reports; vendor reports and correspondence; Commission papers; and applicant and licensee documents and correspondence.

The following documents in the NUREG series are available for purchase from the NRC/GPO Sales Program: formal NRC staff and contractor reports, NRC-sponsored conference proceedings, and NRC booklets and brochures. Also available are Regulatory Guides, NRC reguiations in the Code of Federal Regulations, and Nuclear Regulatory Commission /ssuances.

Documents available from the National Technical Information Service include NUREG series reports and technical reports prepared by other federal agencies and reports prepared by the Atomic Energy Commission, forerunner agency to the Nuclear Regulatory Commission.

Documents available from public and special technical libraries include all open literature items. such as books, journal and periodical articles, and transactions. Federal Register notices, federal and state legislation, and congressional reports can usually be obtained from these libraries.

Documents such as theses, dissertations, foreign reports and translations, and non-NRC conference proceedings are available for purchase from the organization sponsoring the publication cited.

Single copies of NRC draft reports are available free upon written request to the Division of Technical Information and Document Control, U.S. Nuclear Regulatory Commission, Washington, DC 20555.

Copies of industry codes and standards used in a substantive manner in the NRC regulatory process are maintained at the NRC Library, 7920 Norfolk Avenue, Bethesda, Maryland, and are available there for reference use by the public. Codes and standards are usually copyrighted and may be purchased from the originating organization or, if they are American National Standards, from the American National Standards Institute, 1430 Broadway, New York, NY 10018. 


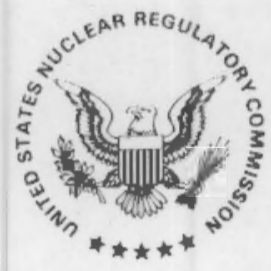

UNITED STATES

NUCLEAR REGULATORY COMMISSION

WASHINGTON, D. C. 20555

January 18, 1984

ERRATA SHEET

for

NUREG/CR-3408

PNL -4788

ORGANOHALOGEN PRODUCTS FROM CHLORINATION

OF COOLING WATER AT NUCLEAR POWER STATIONS

\author{
Prepared by \\ Pacific Northwest Laboratory \\ for the \\ U.S. Nuclear Regulatory Commission
}

The units in Table 6 (page 26) should be expressed in $\mu \mathrm{g} / \mathrm{L}$ (micrograms per liter), and not in $\mathrm{mg} / \mathrm{L}$ as erroneously indicated.

DIVISION OF TECHNICAL INFORMATION

AND

DOCUMENT CONTROL 

NUREG/CR-3408

PNL-4788

RE

\section{Organohalogen Products from Chlorination of Cooling Water at Nuclear Power Stations}

Manuscript Completed: July 1983

Date Published: October 1983

Prepared by

R. M. Bean

Pacific Northwest Laboratory

Richland, WA 99352

Prepared for

Division of Health, Siting and Waste Management

Office of Nuclear Regulatory Research

U.S. Nuclear Regulatory Commission

Washington, D.C. 20565

NRC FIN B2098 


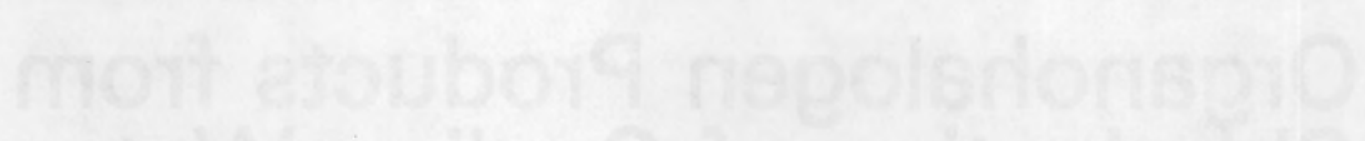

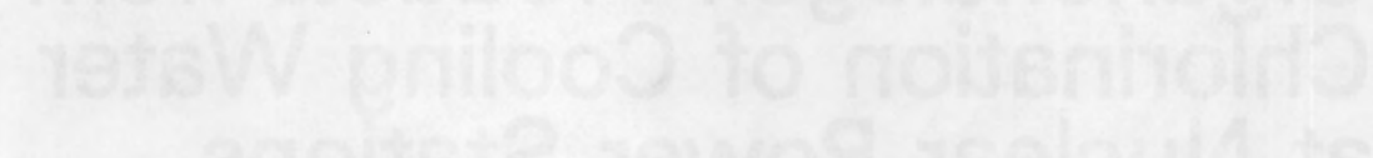

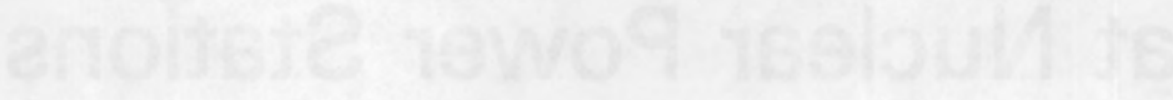




\section{ABSTRACT}

Eight nuclear power units at seven locations in the U.S. were studied to determine the effects of chlorine, added as a biocide, on the composition of cooling water discharge. Water, sediment and biota samples from the sites were analyzed for total organic halogen and for a variety of organohalogen compounds. Haloforms were discharged from all plants studied, at concentrations of a few $\mu \mathrm{g} / \mathrm{L}$ (parts-per-billion). Evidence was obtained that power plants with cooling towers discharge a significant portion of the haloforms formed during chlorination to the atmosphere. A complex mixture of halogenated phenols was found in the cooling water discharges of the power units. Cooling towers can act to concentrate halogenated phenols to levels approaching those of the haloforms. Examination of samples by capillary gas chromatography/mass spectrometry did not result in identification of any significant concentrations of lipophilic base-neutral compounds that could be shown to be formed by the chlorination process. Total concentrations of lipophilic (bioabsorbable) and volatile organohalogen material discharged ranged from about 2 to $4 \mu \mathrm{g} / \mathrm{L}$. Analysis of sediment samples for organohalogen material suggests that certain chlorination products may accumulate in sediments, although no tissue bioaccumulation could be demonstrated from analysis of a limited number of samples. 
SUMMARY

Effective heat transfer is maintained in the cooling systems of many electrical generating plants through periodic treatment of cooling water with chlorine. In view of the many reports in the scientific literature describing the formation of halogenated organic compounds when natural waters are chlorinated, a program of analysis of cooling systems for chlorinated organic products was conducted at eight operating nuclear power units. The objectives of the program were to determine the concentrations of volatile and lipophilic (bioabsorbable) organic halogen compounds found during normal chlorination, to estimate the quantities of these haloorganics discharged by the plants, and to investigate their potential for environmental distribution through analysis of surrounding sediment and biota.

The power units included in this study, their location and sampling dates are:

1. DUANE ARNOLD ENERGY CENTER

Palo, lowa 565 MWe MECHANICAL DRAFT TOWER 26-28 Jun 80
(Cedar River)

2. MILLSTONE NUCLEAR POWER STATION, UNIT \#2

Waterford, Connecticut 830 MWe ONCE-THROUCH COOLING 26-28 Jun 80

(Long Island Sound)

3. ARKANSAS NUCLEAR ONE, UNIT \#1

Russelville, Arkansas 820 MWe ONCE-THROUGH COOLING 18-20 Nov 80

(Dardanelle Reservoir, Arkansas River)

4. ARKANSAS NUCLEAR ONE, UNIT \#2

Russelville, Arkansas 902 MWe NATURAL ORAFT COOLING 18-20 Nov 80

(Dardanelle Reservoir, Arkansas River)

5. EDWIN 1. HATCH NUCLEAR PLANT, UNIT \#2

Baxiey, Georgia 820 MWe MECHANICAL DRAFT COOLING 15-17 Jan 82

(Al tamaha River)

6. BEAVER VALLEY POWER STATION, UNIT \#1

Shippingport, Pennsylvania 885 MWe NATURAL DRAFT COOLING 20-22 Jun 82

(Ohio River)

7. TROJAN NUCLEAR PLANT

Rainier, Oregon 1130 MWe NATURAL DRAFT COOLING 8-10 Sep 82

(Columbia River)

8. PALISADES NUCLEAR GENERATING PLANT

South Haven, Michigan 715 MWe MECHANICAL DRAFT COOLING 15-17 Sep 82

(Lake Michigan) 
Samples were taken of intake and chlorinated discharge water. In the case of tower cooled plants, samples were also taken from the tower basins. Samples were taken for analysis of volatile compounds, principally the haloforms (chloroform, bromoform), for analys is of halogenated phenols, and for analysis of base-neutral organohalogens. A principle sampling procedure involved the adsorption of lipophilic halogenated compounds from water samples onto macroreticular resins. Using this sampling strategy, very large volume samples (100-200 liters) could be taken and conveniently transported to the laboratory for analysis.

Although most of the sampling procedures used for this study had been developed in earlier NRC-sponsored research, some new methods were developed, including methods for analysis of halogenated phenols in water and sediments, and for analysis of volatile halogenated organics in sediments. Analytical procedures for chlorinated organics were performed using a variety of gas chromatographic and mass spectrometric techniques, and microcoulometric measurement of organic halogen.

Analyses of chlorinated plant cooling waters for volatiles showed that the haloform concentrations discharged from plants cooled with towers were lower than expected $(0.5-6 \mu \mathrm{g} / \mathrm{L})$ based on the quantities of chlorine used. Analyses of the exhaust atmospheres from the cooling tower of the E.I. Hatch plant indicated that a considerable fraction of the haloforms were discharged to the atmosphere. Thus, cooling towers, which concentrate many water components, appear to eliminate volatile materials from the water through evaporation. Our data indicated that the Beaver Valley tower discharged lower concentrations of some chlorinated organics, such as trichloroethylene, into the receiving waters than it took in at the intake structure. No evidence was obtained for formation of any volatile halogenated organics other than chloroforms as a result of biocide chlorination.

A complex mixture of chlorinated, brominated and chlorobrominated phenols were found in the chlorinated discharges of most of the plants studied. Halogenated nitrophenols were also found in power plant waters, arising through halogenation of nitrophenols present in the intake waters. The Arkansas facility provided a unique opportunity to compare the halogenated phenol production in a cooling tower with that from a once-through unit, since Arkansas operates both types of units with identical cooling water sources. It was found that the cooling tower discharges significantly higher concentrations of halogenated phenols than the once-through unit because of the higher chlorine usage, and because of the action of the tower to concentrate reactant species. The phenol product distribution in the tower was also different. The highest total concentration of halogenated phenols discharged was found to be $1.4 \mu \mathrm{g} / \mathrm{L}$. 
Few halogenated organic compounds were found in the base-neutral fractions isolated from chlorinated cooling water. Intensive searching of these fractions by capillary chromatography coupled to a mass spectrometer resulted in finding only nine halogenated components which were not also present in the uptake waters. At six of the eight units, no halogenated components were found that were not also in intake samples. Dichlorobenzenes, ubiquitous in the environment, were found at very low $(<0.1 \mu \mathrm{g} / \mathrm{L})$ levels in all intake and discharge samples examined. A previously unreported haloform, dibromoiodomethane, was found in trace concentrations in the discharges (but not intakes) of the Millstone and the Arkansas plants. All evidence we have obtained indicates that most of the halogenated organic material in the baseneutral fraction is polar and non-volatile.

The analyses of sediments from cooling water discharge plumes and control locations indicated that halogenated phenols and other halogenated organic material were present, and the concentrations of these components might be affected by the chlorinated discharges. The evidence for this is not strong however and should be confirmed by other studies. The concentrations of phenols in sediments, when expressed in terms of the organic carbon in the sediment, were tens of parts-per-million. On the other hand, when mussels from the Millstone intake and discharge were examined for halogenated organics, no evidence of bioconcentration of these materials was obtained.

These investigations have shown that both volatile and lipophilic halogenated organic materials are discharged into receiving waters by electrical generating stations that use chlorine as a biocide. The concentrations of individual components are at most a few micrograms per liter (parts-per-billion), and most are formed in much lower concentrations. Cooling towers act to discharge much of the haloform produced by chlorination into the atmosphere through evaporation and drift, while acting to increase the concentrations of halogenated phenols produced. Total concentrations of volatile and lipophilic organohalogen discharged from the power plants studied range from about two to four micrograms chlorine per liter of water. Less than one percent of the chlorine added as biocide is converted to these types of products.

The results of this power plant survey has suggested that further research is needed before a complete assessment of the environmental factors associated with the discharges of organohalogen materials by power plants can be made. Data need to be obtained on the toxicity and potential for bioaccumulation of the brominated and chlorobrominated phenols. More information should be developed concerning the types and concentrations of chlorinated compounds discharged to the atmosphere from cooling towers, and the fate of these discharged materials.

All of the compounds identified and their determined concentrations are listed in the following summary table: 
SUMAARY TABLE Compounds Identified in Samples from Nuclear Power Plants

(All Concentrations in Parts-Per-Billion)

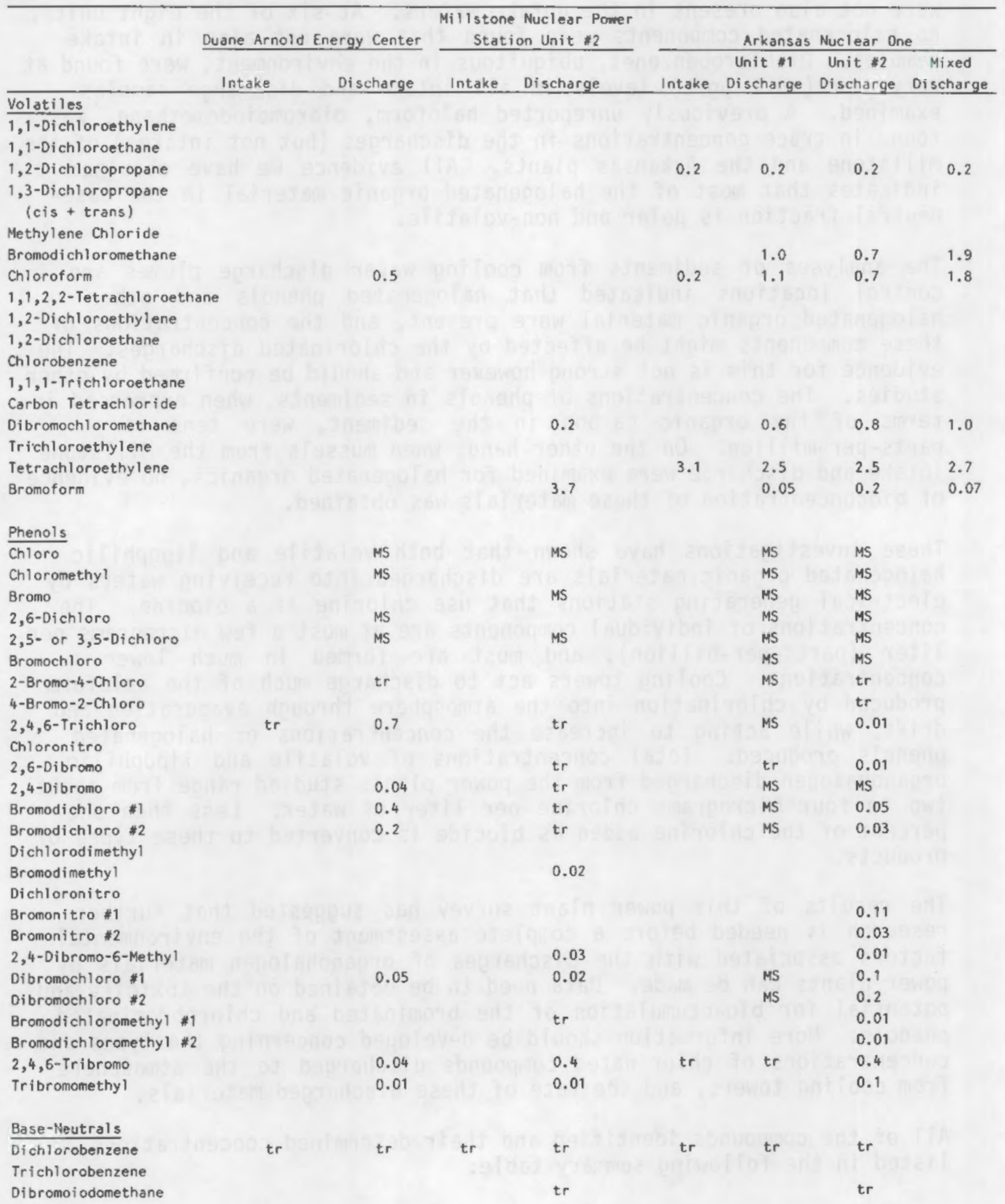




\begin{tabular}{|c|c|c|c|c|c|c|c|}
\hline & \multicolumn{2}{|c|}{ Edwin I. Hatch } & \multicolumn{5}{|c|}{ Beaver Valley Power Station, Unit 11} \\
\hline & & & & Tomer & & Control & Oischarge \\
\hline & Intake & Discharge & Intake & Bosin & Oischarge & Sediment & Sediment \\
\hline \multicolumn{8}{|l|}{ Volatiles } \\
\hline 1,1-0ichloroethylene & & & tr & 0.03 & 0.1 & & \\
\hline 1,1-Dichloroethane & & & 0.01 & & & & \\
\hline \multicolumn{8}{|l|}{ 1,2-Dichloropropane } \\
\hline \multicolumn{8}{|l|}{$\begin{array}{l}\text { 1,3-Dichloropropane } \\
\text { (cis + trans) }\end{array}$} \\
\hline Methylene Chloride & & & 0.1 & 0.1 & 0.4 & 890 & 230 \\
\hline Dichlorobromomethane & & & 0.02 & 0.06 & 0.06 & & \\
\hline Chloroform & & 0.8 & 0.3 & 1.5 & 0.5 & 0.2 & 0.1 \\
\hline \multicolumn{8}{|l|}{$1,1,2,2$-Tetrachloroethane } \\
\hline 1,2-Dichloroethylene & & & 0.1 & & & & \\
\hline 1,2-Dichloroethane & & & 0.02 & & & & \\
\hline \multicolumn{8}{|l|}{ Chlorobenzene } \\
\hline 1,1,1-Trichloroethane & & & 0.1 & & & $\operatorname{tr}$ & 0.2 \\
\hline Carbon Tetrachloride & & & & $\mathrm{tr}$ & $\operatorname{tr}$ & & \\
\hline Chlorodibromomethane & & & 0.3 & 0.1 & 0.1 & & a \\
\hline Trichloroethylene & & & 0.2 & 0.1 & 0.2 & 0.1 & 0.02 \\
\hline Tetrachloroethy lene & & & 0.1 & & & & \\
\hline Bromoform & & & $\operatorname{tr}$ & 0.3 & tr & & \\
\hline \multicolumn{8}{|l|}{ Phenols } \\
\hline$\overline{\text { Chioro }}$ & & MS & MS & & MS & & \\
\hline Chloromethyl & & MS & & & & & \\
\hline Bromo & & MS & & & MS & & \\
\hline 2,6-Dichloro & MS & 0.01 & 0.01 & 0.02 & 0.02 & $\sim 1$ & $\sim 4$ \\
\hline $2,5-$ or $3,5-$ Dichloro & MS & MS & MS & & MS & $\sim 0.3$ & $\sim 2$ \\
\hline Bromochloro & & MS & & 0.02 & 0.01 & & \\
\hline 2-Bromo-4-Chloro & & MS & & 0.01 & 0.01 & & \\
\hline 4-Bromo-2-Chloro & & MS & & 0.01 & $\operatorname{tr}$ & & \\
\hline $2,4,6$-Trichloro & MS & 0.06 & $\operatorname{tr}$ & 0.02 & 0.03 & $\sim 0.3$ & $\sim 1$ \\
\hline Trichloro $\# 2$ & & & & & & $\sim 0.3$ & $\sim 1$ \\
\hline Trichloro $\# 3$ & & & & & & $\sim 0.3$ & $\sim 1$ \\
\hline Chloronitro & & MS & & & MS & & \\
\hline 2,6-Dibromo & & & & 0.02 & 0.02 & & \\
\hline 2,4-0ibromo & & & $\operatorname{tr}$ & 0.05 & 0.03 & & \\
\hline Bromodichloro \#1 & & MS & 0.01 & 0.03 & 0.06 & & \\
\hline Bromodichloro *2 & & MS & & 0.02 & 0.05 & & \\
\hline Dichlorodimethyl & & 0.02 & & tr & tr & & \\
\hline \multicolumn{8}{|l|}{ Bromodimethyl } \\
\hline Dichloronitro & & MS & & & & & \\
\hline Bromonitro $\# 1$ & & MS & & & & & \\
\hline \multicolumn{8}{|l|}{ Bromonitro $* 2$} \\
\hline \multicolumn{8}{|l|}{ 2,4-0ibromo-6-Methy 1} \\
\hline Dibromochloro 1 & & MS & tr & 0.04 & 0.06 & $\sim 0.1$ & $\sim 0.5$ \\
\hline Dibromochloro $* 2$ & & MS & tr & 0.05 & 0.07 & $\sim 0.1$ & $\sim 0.5$ \\
\hline Bromodichloromethyl $* 1$ & & & & & & & \\
\hline \multicolumn{8}{|l|}{ Bromodichloromethyl } \\
\hline 2,4,6-Tribromo & & - & & 0.06 & 0.1 & $\multimap 0.1$ & $\sim 0.5$ \\
\hline Tribromomethy1 & & & & & & & \\
\hline \multicolumn{8}{|l|}{ Base-Neutrals } \\
\hline$\overline{\text { Dichlorobenzene }}$ & tr & $\operatorname{tr}$ & tr & & tr & & \\
\hline Trichlorobenzene & $\operatorname{tr}$ & $\operatorname{tr}$ & tr & & tr & & \\
\hline Dibromoiodomethane & & & & & & & \\
\hline
\end{tabular}




\section{SUMMARY TABLE (Continued)}

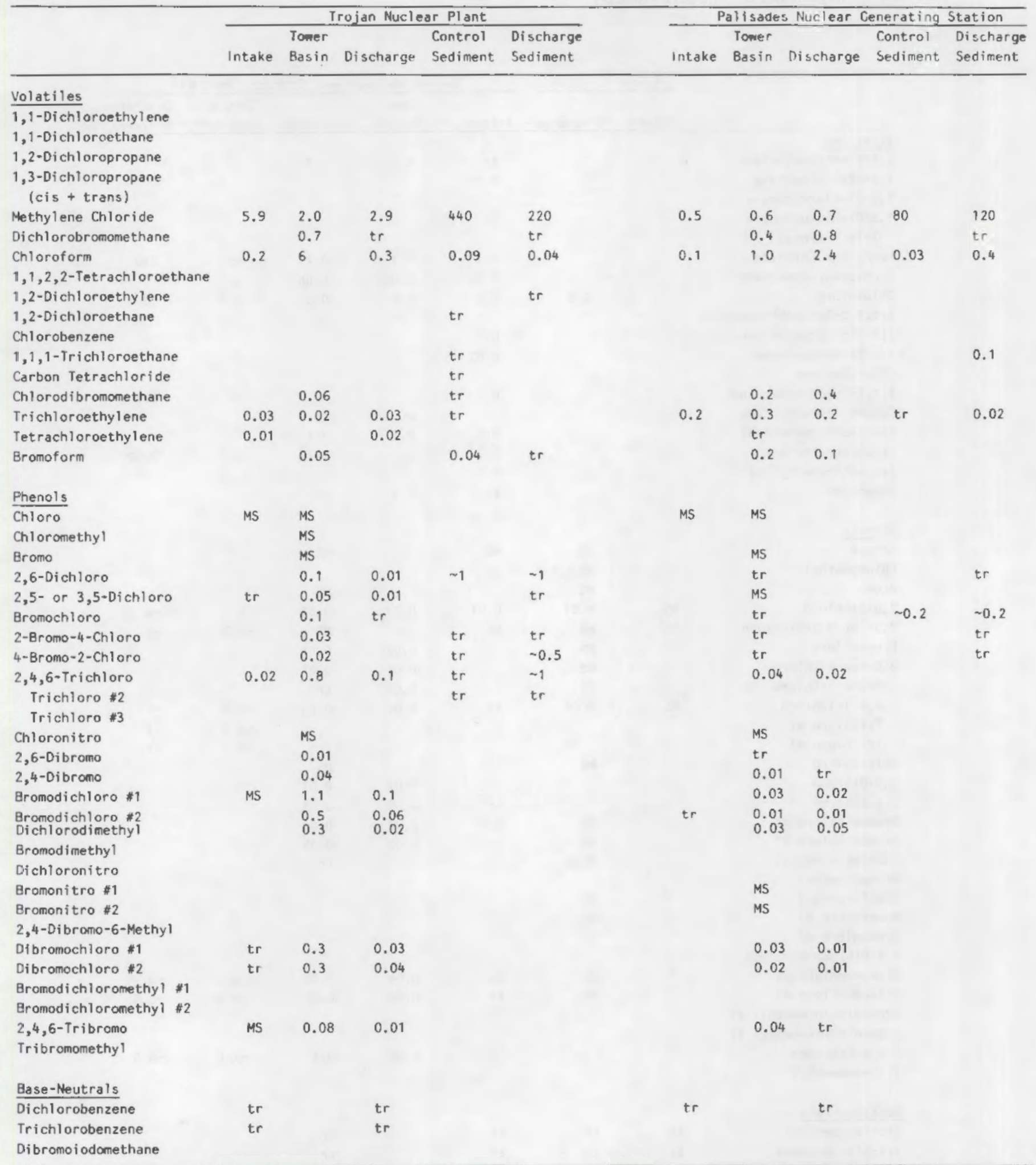

Notes: 1. Data are presented in condensed form; detailed sample analyses are given in the body of this report.

2. Compounds listed were identified by mass spectrometry, except in the determination of volatiles in sediments. These were identified by retention time only.

3. $\operatorname{tr}=$ concentrations detected by electron capture detectors were below 0.1 part-per-billion.

4. MS = identified by CC/MS analysis of XAD-2 extracts, but not folind by electron capture analysis of $1-1$ iter extracts.

5. Phenols in sediments varied widely from sample to sample - concentrations given are estirites only. 
Appendixes

A. Detailed Sampling Procedures and Sample Inventory . . 99

B. Sampling and Analysis of Cooling Tower Atmosphere

for Volatile Halogenated Organics . . . . . 112

C. Total Ion Chromatogram and Spectra of Derivatized

Halogenated Phenols From Trojan Cooling Tower . . 134

D. Spectra of Halogenated Base-Neutral Compounds

Found in Chlorinated Power Plant Water and Not

Found in Nonchlorinated Water . . . . . 147 
TABLE OF CONTENTS

Abstract . . . . . . . . . . . .

Summary . . . . . . . . . . . $v$

List of figures . . . . . . . . . . . . . . . . . . . .

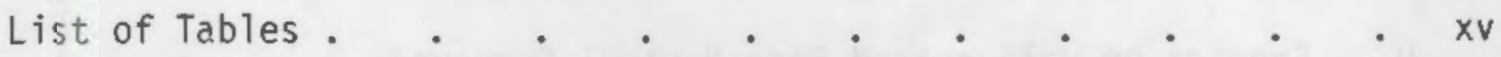

Acknowledgments . . . . . . . . . . xix

1.0 Introduction . $. \quad . \quad . \quad . \quad . \quad . \quad . \quad . \quad .1$

2.0 Sampling at Nuclear Power Units . . . . . . 3

2.1 Sampling Procedures . . . . . . . 3

2.2 Description of Sampling at Individual Power Stations : 6

3.0 Analysis of Power Plant Cooling Waters . . . . . 21

3.1 Anions and Organic Carbon . . . . . . 21

3.2 Haloforms and Other Volatile Halogenated Organics . : 24

3.3 Halogenated Phenols . . . . . . . 28

3.4 Base-Neutral Organohalogen Material and Total
Organic Halogen . . 45

3.5 Sunmary of Organohalogen Concentrations Found at
Nuclear Power Plants and Calculation of Net

4.0 Analysis of Sediments From Discharge Plumes and

Control Sediments • • • • • • •

4.1 Analysis of Sediment for Volatile Organohalogen

Compounds . . . . . . . . . 67

4.2 Analys is of Sediment for Halogenated Phenols: $: \quad$ : 77

4.3 Analysis of Sediment for Base-Neutral and Total . . . 80
Organic Halogen . . 80

5.0 Analysis of Shellfish for Haloform and Organic Halogen . . 86

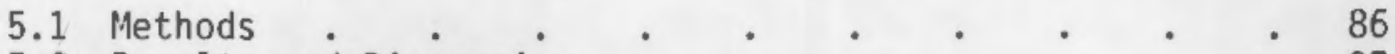

5.2 Results and Discussion . . . . . . . 87

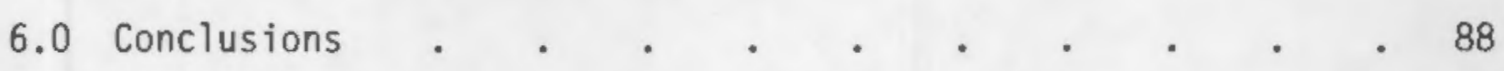

7.0 Recommendations . . . . . . . . . . 90

References . . . . . . . . . . . 93 


\section{LIST OF FIGURES}

1 Arrangement of Equipment for Large Volume Sampling of

Power Plant Water by Adsorption on XAD-2 Resin Columns . . 5

2 Plan of Duane Arnold Energy Center Showing Sampling Locations .

3 Plan of Millstone Nuclear Power Station Showing Sampling Locations .

4 Plan of Arkansas Nuclear One Showing Sampling Locations .

5 Detail of Cooling Water Systems for Arkansas Units \#1 and \#2

6 Plan of Edwin I. Hatch Nuclear Plant Showing Sampling Locations

7 Plan of Beaver Valley Power Station, Unit \#1, Showing Sampling Locations

8 Plan of Trojan Nuclear Plant Showing Sampling Locations .

9 Plan of Palisades Nuclear Generating Plant Showing Sampling Locations . $. \quad . \quad$. . . . . . 18

10 Water Circulation Plan for Palisades Nuclear Generating Plant (from USNRC, 1978) . . . . . . . . . 19

11 Scheme for Analysis of Power Plant Water for Halogenated Phenols . . . . . . . . . . . 29

12 Spectra of Phenols Found in Power Plant Tower Water Samples.

13 Phenols Found in Beaver Valley Discharge Samples . . . 35

14 Electron Capture Capillary Chromatograms of AcetateDerivitized Phenols Found in Trojan Water Samples . . . . 41

15 Electron Capture Capillary Chromatograms of AcetateDerived Phenols Found in Arkansas Water Samples . . . 43

16 Comparison of Halogenated Phenol Distributions From Arkansas Tower and Once-Through Discharge . . . . 44

17 Scheme for Analysis of XAD-2 Extracts for Organic Halogen . 46

18 Modified Purge-andTrap Apparatus for the Determination of Volatiles in Sediments 
19 Chromatograms of Haloform Standards and a Procedural Blank.

20 Chromatograms of Volatile Halocarbon Standards (8 $\mathrm{ng}$ per Component) Analyzed by the Electron Capture Purge-and Trap Technique.

21 Electron Caputre Purge-and-Trap Chromatograms of Beaver Valley Sediment Samples . . . . . . . . 73

22 Electron Capture Purge-and-Trap Chromatograms of Trojan Sediment Samples . . . . . . . . 74

23 Electron Capture Purge-and-Trap Chromatograms of Palisades Sediment Samples . . . . . . . 75

24 Flow Chart for Sediment Extraction and Separation into Acid (Phenol) and Base-Neutral Fraction . . . 77

25 Single Ion Chromatograms Obtained From Chlorinated PCB's in Beaver Valley Discharge Sediment. $M=324,392$ and 426 Correspond to Biphenyls Substituted with 5, 6, 7 and 8 Chlorines $.0 . \quad . \quad . \quad . \quad . \quad .85$ 


\section{LIST OF TABLES}

1 Water Samples Collected at Each Sampling Point . . . 5

2 Description of Sampling Stations . . . . . . 7-8

3 Analys is of Power Plant Waters for Anions and Organic

Carbon . • . . . . . . . . 22

4 Concentration Factors in Cooling Towers at Nuclear

Power Plants . . . . . . . . . . 23

5 Volatile Compounds Searched for in Purge and Trap

Analysis . . . . . . . . . 25

6 Analysis of Water Samples for Volatiles by Purge-and-Trap

(Values Given in $\mathrm{mg} / \mathrm{L}$ of water) . . . . . 26

7 Comparison of Haloform Production: Cooling Towers vs.

Experiments Conducted in 1978-1979 . . . . . . 28

8 Halogenated Phenols Determined to be Present in XAD-2 Extracts

of Chlorinated Power Plant Discharges Using GC/MS . • 33

9 Halogenated Phenols Determined to be Present in XAD-2

Extracts of Power Plants Waters Using GC/MS Analysis . . 34

10 Recovery of Halogenated Phenols From Two-Liter Spiked

Water Samples . . . . . . . . 37

11 Comparison of Electron Capture Analysis with Flame Ionization Analysis. . . . . . . . 37

12 Phenol Recovery From Arkansas Unit \#2 Tower on XAD-2

Resin

13 Analysis of Halogenated Phenols in Methylene Chloride Extracts of Two-Liter Water Samples From Millstone, Arnold, and Arkansas Power Plants . . . . . .

14 Analysis of Halogenated Phenols in Methylene Chloride Extracts of One-Liter Water Samples From Hatch, Beaver Valley, Trojan and Palisades

15a Analysis of XAD-2 Samples for Total Organic Halogen and Haloforms - Duane Arnold

15b Analysis of XAD-2 Samples for Total Organic Halogen and Haloforms - Millstone 
15c Analysis of XAD-2 Samples for Total Organic Halogen and

15d Analysis of XAD-2 Samples for Total Organic Halogen and Haloforms - Edwin Hatch . . . . . . . . 50

15e Analysis of XAD-2 Samples for Total Organic Halogen and Haloforms - Beaver Valley . . . . . .

$15 f$ Analysis of XAD-2 Samples for Total Organic Halogen and Haloforms - Trojan . . . . . . .

$15 \mathrm{~g}$ Analysis of XAD-2 Samples for Total Organic Halogen and Haloforms - Palisades

16 Characteristics of XAD Column Extraction Procedure . . 56

17 Total Non-Volatile Organic Chlorine in Power Plant Waters by Hexane Extraction . . . . . . . 58

18 Total Organic Halogen in Silica Gel Chromatography Fractions From XAD-2 Samples. . . . . . . 59

19 Surmary of Mass Spectral Search for Halogenated Base-Neutral Compounds . . . . . . . . 60

20 Organic Chlorine Found as Haloform, Halophenol and Base/Neutral Material in Power Plants Water. . . . 61

21 Net Discharge of Chlorinated Organics From Nuclear Power Units

22 Estimated Net Daily Oischarge of Haloforms and Halogenated Phenols by Nuclear Power Plants . . . . 66

23 Analysis of Volatile Halocarbons in Bulk Sediment Samples From Power Plant Locations . . . . . . 72

24 Analys is of Volatile Halocarbons in Core Samples at Different Depths.

25 Recovery of Phenols From Trojan Control Sediment . . . 79

26 Analysis of Halogenated Phenols in Sediments Exposed to Power Plant Discharge Plume Versus Control Sediments .

27 Sediment Characteristics at Beaver Valley, Trojan Palisades.

28 Total Halophenol Concentrations in Sediment Samples From Beaver Valley, Trojan, and Palisades 
29a Organic Halogen Content of Sediments From Duane Arnold and Millstone . . . .

$-1$

.

29b Organic Halogen Content of Sediments From Arkansas

30 Total Organic Halogen in Sediments . . . . . . 84

31 Organohalogen in Tissue Samples $\quad . \quad \ldots \quad . \quad . \quad . \quad . \quad 87$ 



\section{ACKNOWLEDGMENTS}

This work was performed for the U.S. Nuclear Regulatory Conmission (NRC) under a Related Services Agreement with the U.S. Department of Energy Contract DE-AC06-76RL0-1830. The author wishes to acknowledge the guidance and assistance provided by Dr. Phillip R. Reed of NRC.

Contributors to this report are:

R. M. Bean

D. A. Neitzel

R. L. Wilson

K. M. McFadden

D. C. Mann

0 . W. Glover

R. N. Lee
Principle Investigator, Staff Scientist Research Scientist Research Scientist Research Scientist Scientist Sr. Technical Specialist Research Scientist

This work would not have been possible without the cooperation of the management, staff, and security personnel of the seven power stations visited by our sampling team, headed by $D$. A. Neitzel. The following individuals were particularly helpful in arranging for the details required for our sampling: Dr. William Renfro, Northest Utilities Service (Millstone); Dr. Dale L. Swindle, Arkansas Power and Light Company (Arkansas Nuclear One); Keith Young, Duane Arnold Energy Center; Howard Rogers, Edwin Hatch Power Plant; Gordon Rich, Portland General Eelctric Company (Trojan); Gerry Veldman, Palisades Nuclear Power Piant; and Jim Wenkhous, Beaver Valley Power Station.

Trade names and registered trademarks are used to assist the reader in replicating the experiments. Their use does not constitute endorsement by Battelle Memorial Institute or the U.S. NRC. 



\section{INTROOUCTION}

Concern has been expressed about the presence of halogenated organic compounds in water since Dowty et al. (1975) detected volatile organochlorine compounds in a New Orleans area municipal water treatment facility. This report was followed with evidence adduced by Rook (1974), Glaze and Henderson (1976), Jolley (1975) and others that the presence of a variety of organohalogen compounds in drinking waters and wastewater effluents is a consequence of current chlorination treatment practices. Halogen-containing organic compounds have been reported to adversely affect aquatic biological species through direct toxic action (Roesijadi et al., 1976), as well as through indirect mechanisms such as interference with reproduction success (Gehrs et al., 1974), and interference with photosynthesis (Eppley et a1., 1976). A number of halogenated organic compounds also have been found to concentrate in the tissues of aquatic organisms (Zitko and Hutzinger, 1976), which in the case of food fish could increase the hazard of these compounds to human health.

About 26,000 tons of chlorine are used annualiy in the U.S. in treatment of cooling water for electricity generating plants (Hamilton, 1978), many of which use natural riverine or estuarine waters for once-through cooling. Seventy-one percent of the once-through cooled power plants in the U.S. regularly use chlorine as a biocide to maintain good heat transfer (USEPA, 1982). Plants that have cooling towers also use chiorine, although the water volumes discharged from these plants are much lower than once-through facilities. Jolley et al. (1978) was one of the first to provide evidence that chlorinated organics were present in chlorinated cooling water discharges. A biological and chemical assessment of power plant chlorination was published (Hall et al., 1981); however, very 1ittle information about halogenated organics was available for inclusion in that assessment.

In response to concerns about the environmental consequences of power plant cooling water chlorination, a project was initiated by the USNRC to study the chemistry, aquatic toxicology, and bioavailability of the products of water chlorination. The studies, initiated in 1976 at Pacific Northwest Laboratory, show that addition of low levels $(2 \mathrm{mg} / \mathrm{L})$ of chlorine to natural waters produced haloforms in concentrations orders of magnitude lower than the $\mathrm{LC}_{50}$ 's measured for a number of fresh and salt water organisms. Biouptake of haloforms by aquatic biota was found to be no more than an order of magnitude greater than ambient water concentrations for most species studied. Chlorination also produced nonhaloform 7 ipophilic organohalogen products in concentrations much lower than the haloforms, al though no evidence was obtained that suggested significant biomagnification of these during chronic exposure of juvenile salmon to chlorinated fresh water. No marked effects were noted in organisms chronically exposed to chlorinated waters, but changes in general condition were observed. The results from the Nuclear Regulatory Commission Program have been presented in six Topical Reports (Bean and Riley, 1980; Anderson and Lusty, 1980; Anderson et al. 
1980; Gibson et al., 1980a, Gibson et al., 1980b; and Bean et al., 1980) and summarized in a Final Report (Bean et al., 1981).

A principle recommendation of the Final Report (Bean et a1., 1981) was to conduct a sampling program at nuclear power stations to verify the concentrations of organohalogen material produced in experimental water chlorination studies, and to determine the effects of plant operations on the quantities and distributions of halogenated products of chlorination. This recommendation was implemented by the Nuclear Regulatory Commission in 1979. The results of these field studies of nuclear power plant discharges are presented in this report.

The primary objectives of the power plant studies were:

- To apply well documented procedures to the sampling and analysis of chlorinated nuclear power plant discharges for organohalogen compounds of environmental concern. These compounds include both volatile and lipophilic organic compounds containing chlorine or bromine.

- To use the qualitative and quantitative data obtained to estimate the quantities of organohalogen components discharged to receiving waters by nuclear power plants as a result of biocide control practices.

- To investigate the environmental distribution of the organohalogens discharged by nuclear power plants through analyses of environmental sediment and biological samples.

The sampling and analytical methods used were developed, for the most part, during the course of the previous program (Bean, 1980) and are not detailed in this report. Methods not previously reported are described in detail. A principal method used for collection of large water samples was the XAD resin adsorption method. This method has been shown by Junk et al. (1974) to be a very effective means for sampling lipophilic organic compounds present in trace quantities in water, and has been documented extensively in the literature (0sterroht, 1974; Van Rossum and Webb, 1978; Dressler, 1979; Picer and Picer, 1980). XAD resins do not efficiently trap all the chlorinated material produced by low level chlorination of natural waters. Glaze et al. (1980) has shown that activated charcoal adsorbs as much as five times more of the organic halogen than does XAD. The nature of the material not adsorbed by XAD resins has been characterized as largely higher molecular weight, humate-derived organic material (Glaze et al., 1982; and Saleh and Mokti, 1983). The focus of the studies reported herein has been on those chlorinated organic compounds that, because of their volatility or lipophilicity, have a potential for causing environmental or health concerns. Thus, the analysis and characterization of the more polar halogenated material that is not adsorbed on XAD resins has not been addressed in these studies. Data presented in this report concerning concentrations and total quantities of total organic halogens discharged from power plants refers to volatile and lipophilic organohalogen material only. 


\section{SAMPLING AT NUCLEAR POWER UNITS}

\subsection{Sampling Procedures}

A primary goal of the sampling task was to obtain water samples for determination of concentrations of halogenated organic material discharged by nuclear power plants during chlorination. Of equal importance was the ability to estimate the contribution of halogenated organics to receiving waters by each power unit. This latter information required knowledge of water flow rates, evaporation losses, concentration factors, chlorination schedules, and other plant operating and design data. To insure that this information was accurate and up-to-date, and that our samplings were conducted at the correct times and locations, preliminary visits were made to each power plant. Normally these visits were made well in advance of the actual sampling trip, although on two occasions (Hatch and Arkansas), the preliminary site inspection was performed the day prior to sampling activities. Prior coordination was also needed in order to establish locations for sediment and biological sampling. These samples were taken to determine relationships between power plant operation and environmental concentrations of organohalogen compounds.

Many of the water sampling procedures used at nuclear power plants were developed during a previous study for the NRC of the effects of low-level chlorination on ten water bodies across the United States (Bean et al., 1980). Therefore, sampling procedures will be described in detail only if they are new, or if they differ significantly from the previous practice. A detailed sampling protocol is provided in the Appendix A.

\subsubsection{Water Samples}

From our previous work (Bean et al., 1980) with low-level chlorination, we learned that large volumes of water $(100-200 \mathrm{~L})$ were required in order to obtain sufficient organohalogen material for analysis. Our method of sampling by adsorption of organics onto XAD-2 resin, after procedures described by Junk et a1. (1974), Suffet et al. (1976), and Glaze et al. (1977), had proven to be a good field method for sampling these large water volumes. However, the long time required to collect these samples (>24 hr) was not compatible with the chlorination schedules of the power plants, which were on the order of an hour or less, and often performed only once a day. To allow us to take a large enough sample within the short time permitted, the sample first had to be collected in a bulk container before adsorption on the XAD resin columns could be performed.

Fifty-five-gallon drums coated with polyvinyl fluoride (PVF) polymer (baked on at $400^{\circ} \mathrm{C}$ ) were used for collection of intake, tower basin, and discharge sampies. The polymer coating was intended to prevent metalcatalyzed reactions of active chlorine during sampling. Prior to taking a chlorinated sample of discharge or tower basin water, the total 
residual oxidant was measured with a portable Fisher-Porter amperometric titrator. The barrel was filled when residual measurements indicated that the residual chlorine target was being approached. The barrel was filled in about 30 minutes after sampling started using a $2.5 \mathrm{gal} / \mathrm{min}$ pump. Only teflon and stainless steel came into contact with the sample during the barrel-filling operation.

During the filling operation, $\mathrm{pH}$ and temperature were recorded, and then an excess of sodium sulfite was added to destroy the active chlorine. Destruction of residual chlorine was performed for two reasons. First, the continued presence of active chlorine during the $X A D-2$ sampling would allow organic substrate to be exposed much longer to high concentrations of oxidant than under actual plant operations, where chlorinated water is rapidly diluted with unchlorinated receiving water. We have found in other studies of chlorinated water (Bean et al., 1982) that chlorinated water continues to generate haloforms for some time after the sample is taken, unless sulfite is added. Whether the same amount of haloform production occurs after extensive dilution in receiving waters is not known, but is unlikely, since a variety of other chlorine-reducing processes take place in natural waters which do not produce haloform (Helz et al., 1983). The second reason for addition of sulfite was to prevent active chlorine from reacting with the organic matrix of the XAD-2 resin to produce chlorinated products. The formation of such products have been demonstrated in previous studies (Bean et a1., 1978).

After addition of sulfite and sufficient $\mathrm{H}_{2} \mathrm{SO}_{4}$ to bring the $\mathrm{pH}$ to 4 , the water was pumped through duplicate sets of two $2.5 \times 22.9 \mathrm{~cm}$ stainless steel columns filled with XAD-2 resin (cleaned by the method of Junk et a1., 1974). The sampling arrangement is shown in Figure 1 . Water flow was adjusted to about $80 \mathrm{~mL} / \mathrm{min}$ for each column set. In addition to the XAD-2 samples, additional water samples were removed from the sample barrel. A listing of these samples is shown in Table 1. Purge-and-trap samples were taken by completely filling septum-capped $125 \mathrm{ml}$ glass vials. Solvent extractions were with two successive $25 \mathrm{ml}$ portions of solvent in a separatory funnel, then stored in glass bottles with teflon-lined caps.

In addition to the samples taken from the barrel, two other types of water samples were taken. Bulk water samples were taken directly from the water source without addition of any reagents. This sample was a contingency sample, and since it had not come into contact with sampling equipment or chemicals, it could be used to eliminate possibilities of contamination by our apparatus. Hexane extracts of water samples taken directly from intake and receiving water bodies were obtained at the first three plants sampled. These samples were not treated with any chemicals before extraction.

Water samples were stored at $0^{\circ} \mathrm{C}$ during sampling operations, shipped to the laboratory on ice by special-service freight, and stored at $4^{\circ} \mathrm{C}$ prior to analysis. 


\section{TABLE 1. Water Samples Collected at Each Sampling Point}

\begin{tabular}{|c|c|c|c|}
\hline Sample & Number & Water Volume & Component Analyzed \\
\hline $\begin{array}{l}\text { XAD-2 columns } \\
(80 \mathrm{~mL} \text { resin })\end{array}$ & $\begin{array}{l}2 \text { sets of } 2 \\
\text { columns in } \\
\text { series }\end{array}$ & 100 to $200 \mathrm{~L}$ & $\begin{array}{l}\text { Total organic chlorine } \\
\text { (Claze et al., 1976) } \\
\text { Base-neutral organic chlorine } \\
\text { B-N's and phenols (GC/MS) }\end{array}$ \\
\hline Purge-and-trap & 3 & $125 \mathrm{~mL}$ & $\begin{array}{l}\text { Volatiles } \\
\text { (Bellar and Lichtenberg, 1974) }\end{array}$ \\
\hline Methylene chloride extracts & 3 & 1 or $2 \mathrm{~L}$ & Halogenated phenols (EC/CC) \\
\hline Hexane extracts ${ }^{(a)}$ & 3 & 1 or $2 \mathrm{~L}$ & Total organic chlorine \\
\hline Bulk water & 3 & $1 \mathrm{~L}$ & Contingency sample \\
\hline Filtered water & 3 & $100 \mathrm{~mL}$ & Inorganic chemistry \\
\hline
\end{tabular}

(a) Hexane extracts of water were also taken from various intake and discharge locations at some power plants. These are referred to as "in situ" samples.

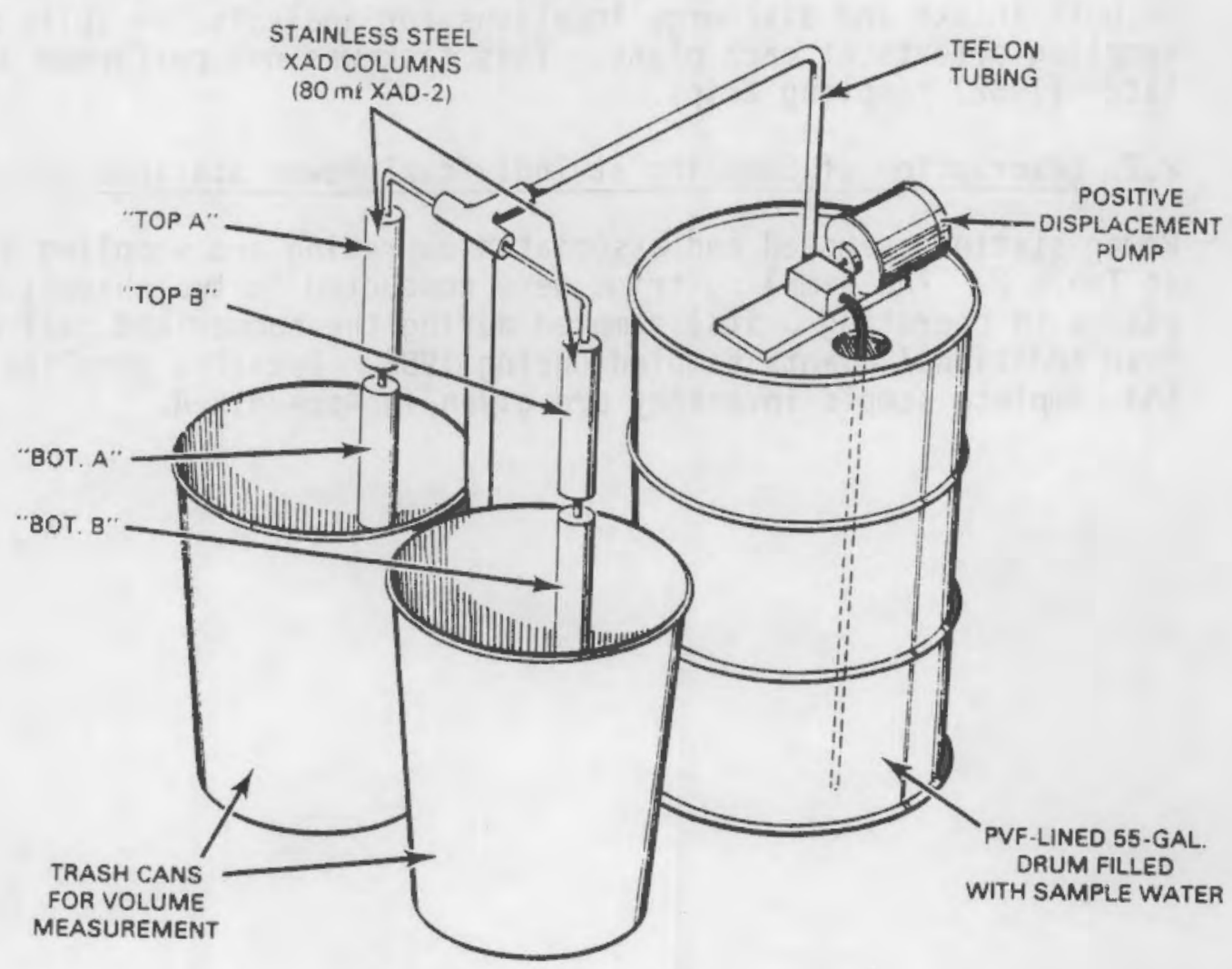

\section{FIGURE 1. Arrangment of Equipment for Large Volume Sampling of Power Plant Water by Adsorption on XAD-2 Resin Columns}




\subsubsection{Sediment Samples}

Sediment samples were taken from discharge and central locations using SCUBA diving equipment. Lexan cylinders were used to collect cores $5 \times 15 \mathrm{~cm}$. At the last three plants sampled, bulk sediment samples were taken from discharge and control locations by hand-scraping surface sediments (top $2 \mathrm{~cm}$ ) from an area of approximately $0.5 \mathrm{~m}^{2}$. The samples were kept at $0^{\circ} \mathrm{C}$ until a freezer could be located to freeze them. They were shipped to the Taboratory on dry ice.

\subsubsection{Biological Specimens}

All biological samples were taken by a trained field biologist (D.A.N.) using SCUBA diving gear. Collection activities were conducted along linear transects established prior to diving to insure adequate coverage of the sampling area. When present, sedentary invertebrates were collected by hand in sufficient quantity to yield $100 \mathrm{~g}$ tissue (wet weight). Samples were preserved and shipped frozen. At the first three locations visited, only one plant (Millstone) yielded sufficient tissue at both intake and discharge locations for analysis, in spite of all-day sampling efforts at each plant. This task was not performed during later (1982) sampling trips.

\subsection{Description of Sampling at Individual Power Stations}

Power stations sampled and associated operating and sampling data are given in Table 2. The sampling trips were conducted in two phases; with three plants (4 operating units) sampled during the summer and fall of 1980, and four additional plants sampled during 1982. Detailed sampling procedures and complete sample inventory are given in Appendix A. 
TABLE 2. Description of Power Stations and Sampling Conditions

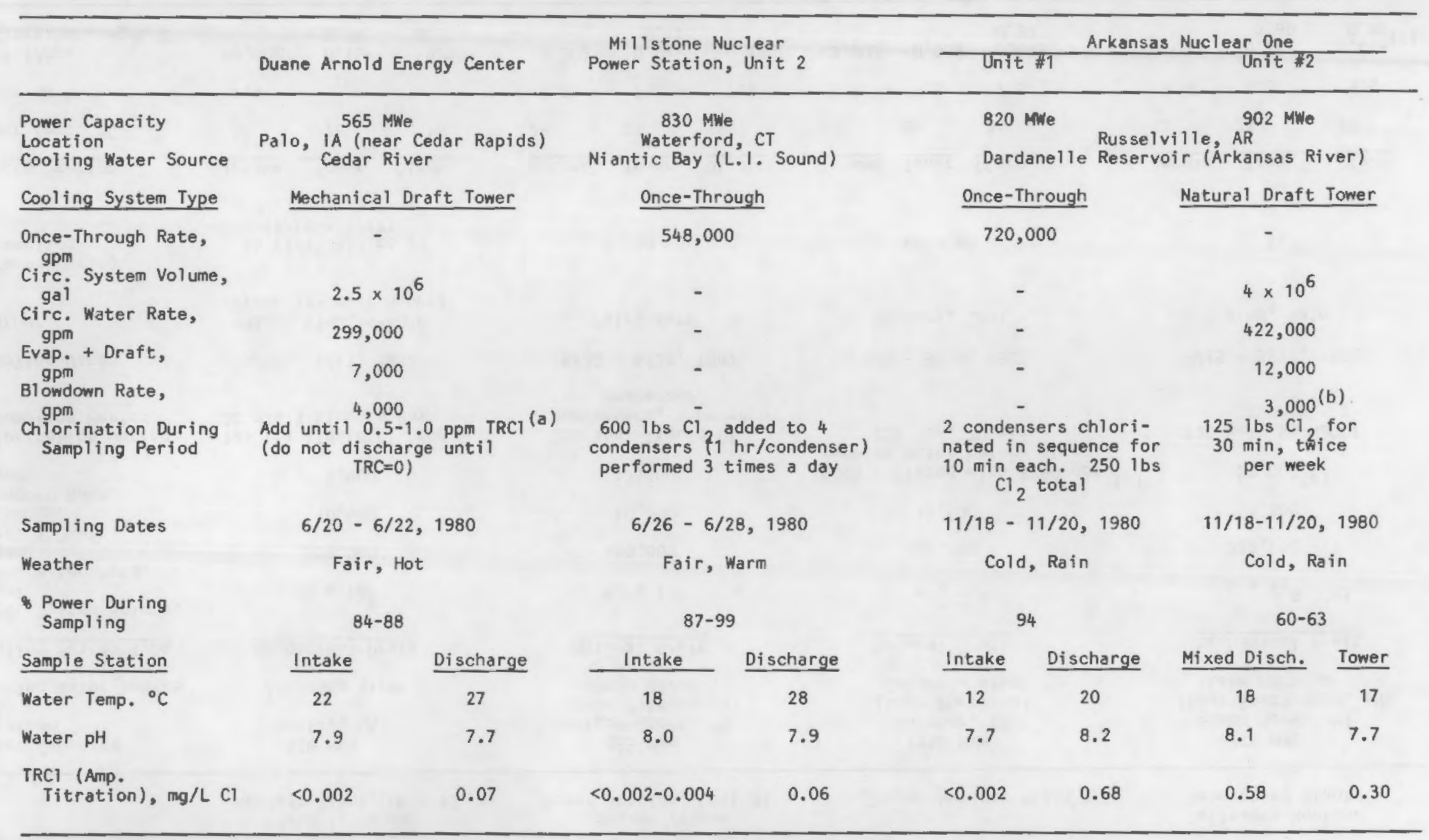

(a) Blowdown flow stopped during chlorination, discharged when residual is $\leq 0.1 \mathrm{mg} / \mathrm{L}$

(b) Discharges into Unit \#1 discharge 
TABLE 2. Description of Power Stations and Sampling Conditions (Continued)

\begin{tabular}{|c|c|c|c|c|c|c|c|c|c|c|c|}
\hline & \multicolumn{2}{|c|}{$\begin{array}{l}\text { Edwin 1. Hatch } \\
\text { Nuclear Plant, Unit \#2 }\end{array}$} & \multicolumn{3}{|c|}{$\begin{array}{l}\text { Beaver Valley } \\
\text { Power Station, Unit \#1 }\end{array}$} & \multicolumn{3}{|c|}{ Trojan Nuclear Plant } & \multicolumn{3}{|c|}{$\begin{array}{l}\text { Palisades Nuclear } \\
\text { Generating Plant }\end{array}$} \\
\hline $\begin{array}{l}\text { Power Capacity } \\
\text { Location } \\
\text { Cooling Water Source }\end{array}$ & \multicolumn{2}{|c|}{$\begin{array}{l}820 \text { MWe } \\
\text { Baxley, GA } \\
\text { Altamaha River }\end{array}$} & \multicolumn{3}{|c|}{$\begin{array}{l}885 \text { Mwe } \\
\text { Shippingport, PA } \\
\text { (near Pittsburgh) } \\
\text { Ohio River }\end{array}$} & \multicolumn{3}{|c|}{$\begin{array}{c}1130 \text { MWe } \\
\text { Rainier, OR } \\
\text { (near Portland) } \\
\text { Columbia River }\end{array}$} & $\begin{array}{l}\text { Sou } \\
\text { (near } \\
\text { La }\end{array}$ & $\begin{array}{l}715 \text { MWe } \\
\text { uth Haven, } \\
\text { r South Be } \\
\text { ake Michig }\end{array}$ & $\underset{\text { and, }}{M \mid}$ (N) \\
\hline Cooling System Type & \multicolumn{2}{|c|}{ Mechanical Draft } & \multicolumn{3}{|c|}{ Natural Draft } & \multicolumn{3}{|c|}{ Natural Draft } & \multicolumn{3}{|c|}{ Mechanical Draft } \\
\hline $\begin{array}{l}\text { Circ. System Volume, } \\
\text { gai } \\
\text { Circ. Water Rate, }\end{array}$ & \multicolumn{2}{|c|}{$12 \times 10^{6}$} & \multicolumn{3}{|c|}{$12 \times 10^{6}$} & \multicolumn{3}{|c|}{$5 \times 10^{6}$} & \multicolumn{3}{|c|}{$5 \times 10^{6} \quad(d)$} \\
\hline & \multicolumn{2}{|r|}{556,000} & \multicolumn{3}{|c|}{480,000} & \multicolumn{3}{|c|}{425,000} & \multicolumn{3}{|c|}{222,000} \\
\hline Blowdown Rate, & \multicolumn{2}{|r|}{10,400} & \multicolumn{3}{|c|}{10,000} & \multicolumn{3}{|c|}{11,500} & \multicolumn{3}{|c|}{7,300} \\
\hline gpm & \multicolumn{2}{|r|}{8,900} & \multicolumn{3}{|c|}{17,500} & \multicolumn{3}{|c|}{$\begin{array}{l}5000 \text { (Diluted with } 8200 \mathrm{gpm} \text { (c) } \\
\text { service water before disch.) }\end{array}$} & \multicolumn{3}{|c|}{$27,000^{(e)}$} \\
\hline $\begin{array}{l}\text { Chlorination During } \\
\text { Sampling Period }\end{array}$ & \multicolumn{2}{|c|}{$\begin{array}{l}125 \text { Ibs liquid } \mathrm{Cl}_{2} \text { for } \\
30 \text { min } 3 \text { times a day }\end{array}$} & \multicolumn{3}{|c|}{$\begin{array}{c}250 \text { lbs. liquid } \mathrm{Cl}_{2} \text {, } \\
\text { condensers, } 1 \mathrm{hr} \text { each } \\
\text { condenser }\end{array}$} & & $0 \mathrm{lbs}, 7$ & $70 \mathrm{~min}$ & \multicolumn{3}{|c|}{$\begin{array}{c}120 \mathrm{gal}, 8 \% \mathrm{NaOCl} \\
40 \mathrm{~min}\end{array}$} \\
\hline Sampling Dates & \multicolumn{2}{|c|}{$1 / 15-1 / 17,1982$} & \multicolumn{3}{|c|}{$6 / 20-6 / 22,1982$} & \multicolumn{3}{|c|}{$9 / 8-9 / 10,1982$} & \multicolumn{3}{|c|}{$9 / 15-9 / 17,1982$} \\
\hline Weather & \multicolumn{2}{|c|}{$\begin{array}{l}\text { Rain, Wind, }<-10^{\circ} \mathrm{C} \\
\text { (River } 12^{\prime} \text { over banks) }\end{array}$} & \multicolumn{3}{|c|}{ Fair, Warm } & & owers, C & $\mathrm{CoO}$ & & Wind, Rair & \\
\hline $\begin{array}{l}\text { 8ower During } \\
\text { Sampling }\end{array}$ & $24(1)$ & $\begin{array}{l}15 / 82) \text { to } 71 \\
6+1 / 17)\end{array}$ & & 90 & & & $65-80$ & & & 96 & \\
\hline Sample Station & Intake & Tower Disch. & Intake & Tower & Disch. & Intake & Tower & Disch. & Intake & Tower & Disch. \\
\hline Water Temp. ${ }^{\circ} \mathrm{C}$ & 5 & 16 & 28 & 27 & 29 & 22 & 24 & 24 & 22 & 25 & 25 \\
\hline Water $\mathrm{pH}$ & 7.4 & - & 7.2 & 7.2 & 7.2 & 7.7 & 7.5 & 7.5 & 7.5 & 5.5 & 5.5 \\
\hline $\begin{array}{l}\text { TRCl (Amp. } \\
\text { Titration, mg/L Cl }\end{array}$ & $<0.002$ & $\begin{array}{l}0.10- \\
0.51\end{array}$ & $<0.002$ & $\begin{array}{l}0.04- \\
0.17\end{array}$ & 0.18 & $<0.002$ & $<0.002$ & $\begin{array}{l}0.44^{-} \\
0.87\end{array}$ & $<0.002$ & $0.28-$ & $\begin{array}{l}0.04- \\
0.86\end{array}$ \\
\hline
\end{tabular}

(c) Blowdown flow stopped during chlorination, discharged when residual is no ionger detectable

(d) Each of two condenser sections are cooled with independent cooling systems: data are for North Tower (west condenser section)

(e) Blowdown mixed in a mixing basin with blowdown from South Tower and with 11,000 gpm dilution before discharge

(f) Sampling location produced high value - actual discharge after complete mixing was $<0.5 \mathrm{mg} / \mathrm{L} \mathrm{Cl}$ 


\subsubsection{Duane Arnold Energy Center}

- Date Sampled: June 20-22, 1980

- Location: Palo, Iowa (Cedar River)

- Cooling System: Mechanical Draft

Duane Arnold Energy Center adds chlorine each evening for approximately an hour. The target concentration for chlorine residual is about one ppm. The chlorinated water is recirculated through the plant with additional water added to compensate for evaporative losses. Discharge (blowdown) of the cooling water is delayed until the residual falls below $0.05 \mathrm{ppm}$. This often requires an eight to twelve-hour closed loop mode of operation. After blowdown is initiated, the plant operates in an open loop mode circulating the water through the entire system once (including cooling towers) before being discharged. There is no biocide added in the open loop mode.

Sampling locations at Duane Arnold are given in Figure 2. Intake samples were collected approximately 20 to 30 meters upstream from the pumphouse. The discharge is a 1-meter diameter concrete culvert which empties into a

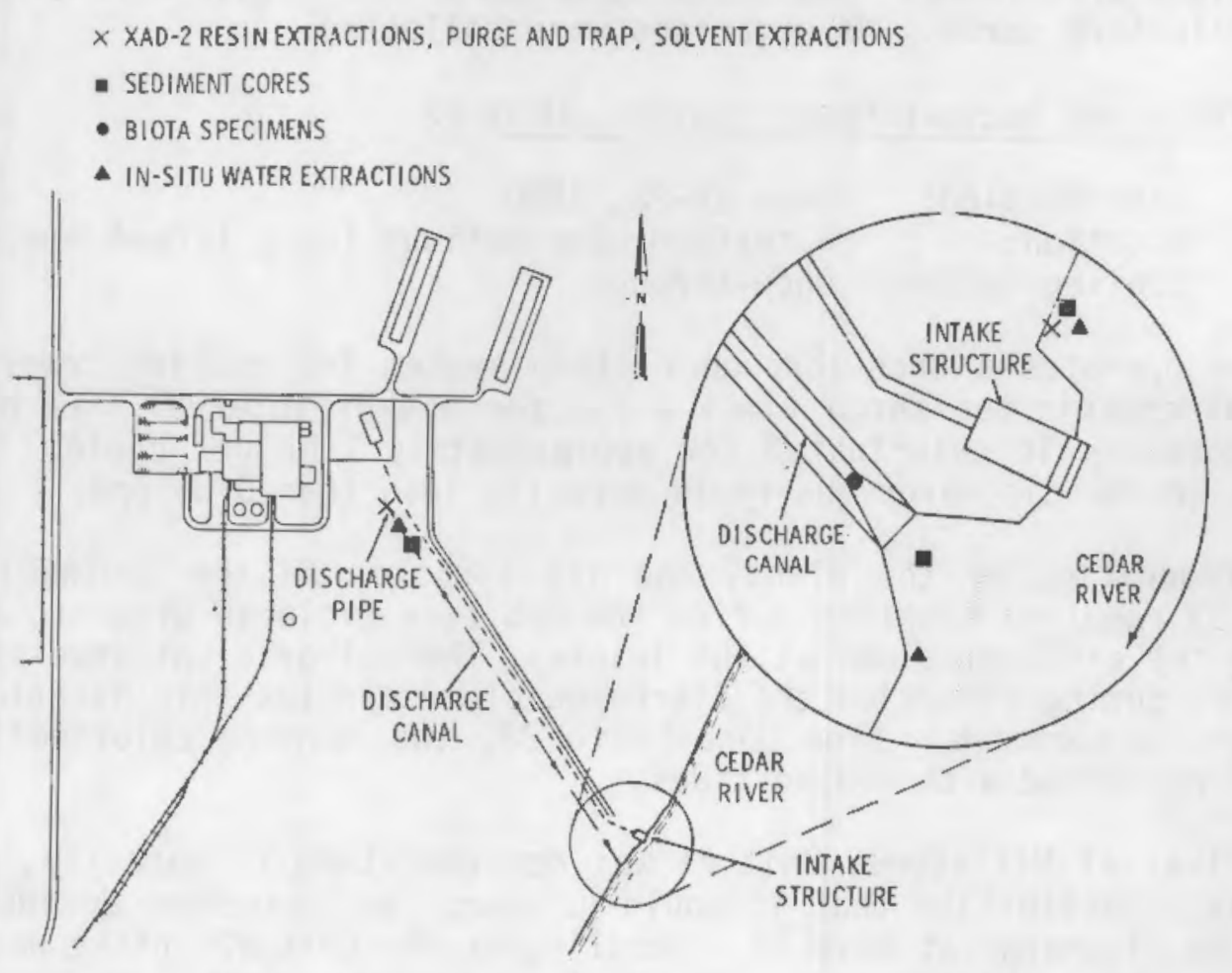

FIGURE 2. Plan of Duane Arnold Energy Center Showing Sampling Locations 
shallow canal outside the security fence. Sampling was conducted at the mouth of the culvert. It was impossible to sample the same water at the intake and discharge because the water was recirculated inside the plant for up to 12 hours prior to discharge. The discharge sample was taken first, then the intake sample.

Three sediment cores were collected at three sites. Intake samples were collected upstream and on the intake side of the river within $50 \mathrm{~m}$ of the site for water sample collection. Samples were collected within $10 \mathrm{~m}$ of the shore in less than $3 \mathrm{~m}$ of water. Receiving-water cores were collected where the discharge canal flows into the river. The depth was less than $3 \mathrm{~m}$. Discharge canal cores were collected from the first sediment closest to the discharge pipe.

The only observed aggregation of biological specimens were in the discharge canal. Bags of these small freshwater clams were collected, which were tentatively identified as fingernail clams, Sphaerium transversum. Visual inspection of the bottom was not possible in the river. The water was very turbid and visibility was very poor. Buckets of sediment were collected from the area where the core samples were taken. These samples were taken at regular transects across the face of the discharge. The sediment was washed through a $0.75 \mathrm{~cm}$ wire mesh screen. No organisms were found. Sediments upstream of the intake were examined while collecting cores. No organisms were collected.

\subsubsection{Millstone Nuclear Power Station, Unit \#2}

- Date Sampled: June 26-28, 1980

- Location: Waterford, Connecticut (Long Island Sound)

- Cooling System: Once-through

Millstone operates a once-through cooling system (no cooling towers). The plant chlorinates three times a day for a 4-hr interval. Each of four condensers is chlorinated for approximately $1 \mathrm{hr}$ per cycle. The residual in the discharge quarry is normally less than $0.05 \mathrm{ppm}$.

The configuration of the plant, and its location on the peninsula (Figure 3 ) required sampling during the ebb tide cycle in order to avoid sampling the effluent plume at the intake. Thermal gradient studies have shown that during floodtide the discharge plume circles into Niantic Bay to the intake structures. From June 26 to 29, the morning chlorination interval coincided with ebbing tides.

Upon arrival at Millstone, Unit \#1 was not operating to capacity, and there was a possibility that it would go down. We therefore decided to sample the discharge at Unit \#2. Sampling at the Unit \#2 intake was not possible without gaining access to the high security area. We took the intake sample at the Unit \#1 intake, outside the security fence, approximately 100 meters from intake at Unit \#2. Residence time of the 


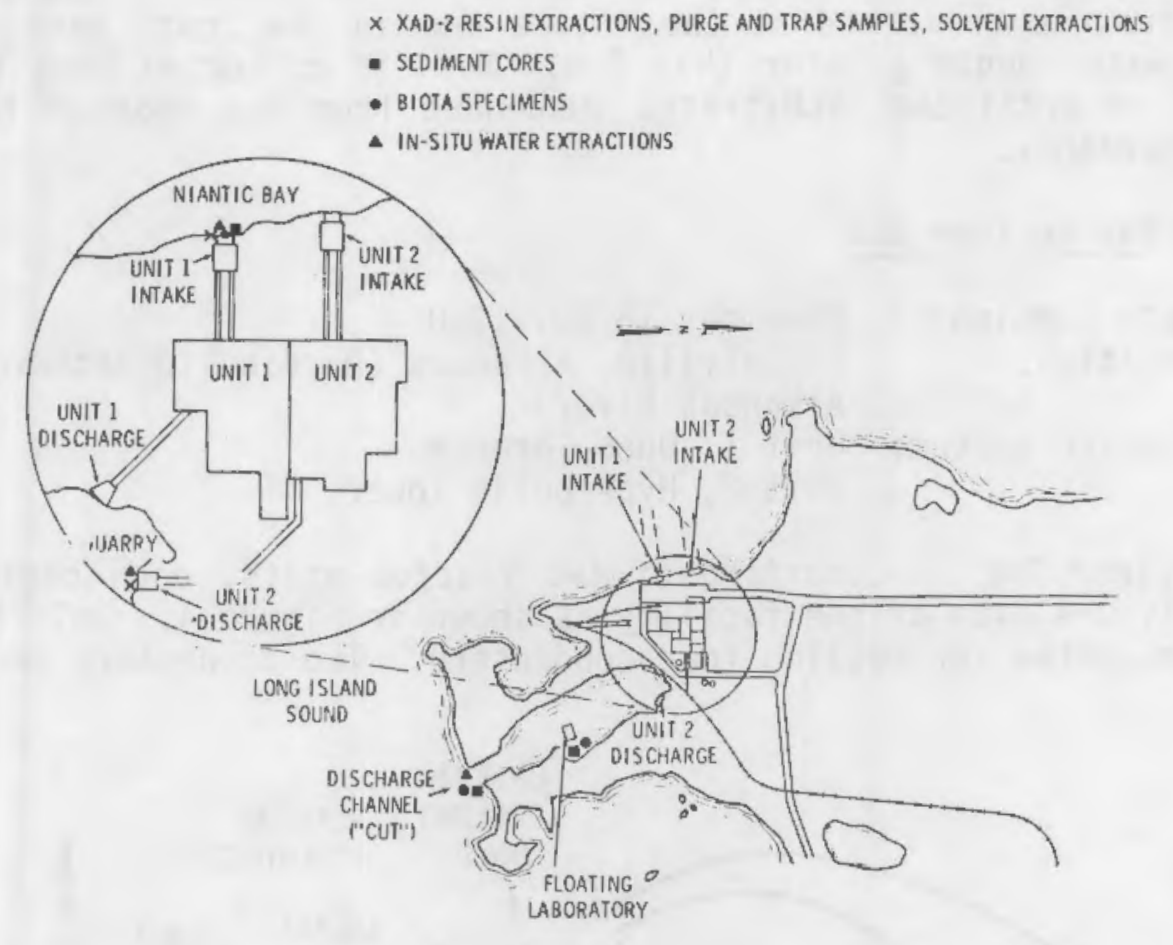

FIGURE 3. Plan of Millstone Nuclear Power Station Showing Sampling Locations

cooling water is about 1 min. The discharge sample was taken first, then the intake sample, with about a 5 to 10 min interval between samplings.

During a second filling of the sample barrel at the intake, an unexpected chlorine-produced residual of 0.002 to $0.004 \mathrm{mg} / \mathrm{L}$ was detected. Since the residual was more than an order of magnitude less than in the discharge, the sample was taken for analysis. It was suggested by Millstone personnel that the residual may have resulted from the intake design. Chlorine is diffused into the seawater in front of the intake pumps, and it is possible that, under the proper conditions, there is diffusion or a backwash out of the intake and into Niantic Bay.

Sediment cores were collected at three sites. Water depth for intake sediment approximately $5 \mathrm{~m}$. Receiving water cores were collected within $50 \mathrm{~m}$ of the "cut" which is the point at which water leaves the discharge quarry and enters Long Island Sound. Water depth was approximately $5 \mathrm{~m}$. Quarry samples were collected between the shore and the Millstone floating laboratory. Water depth was approximately $3 \mathrm{~m}$. 
Blue mussels (Mytilus edulis) were collected at the same locations as sediment. Mussels collected at the intake and in the "cut" were on rocks at a water depth greater than $3 \mathrm{~m}$. Mussels collected from the quarry were on artificial substrates suspended from the side of the floating laboratory.

\subsubsection{Arkansas Nuclear One}

- Date sampled: November 18-20, 1980

- Location: Russelville, Arkansas (Dardanelle Reservoir, Arkansas River)

- Cooling System: Unit 1, Once-Through Unit 2, Hyperbolic Tower

Arkansas Nuclear One is comprised of two reactor units, each cooled independently. A plan of the facility is shown in Figure 4 . Unit \#1 has a once-through system for cooling four condensers. Two condensers are

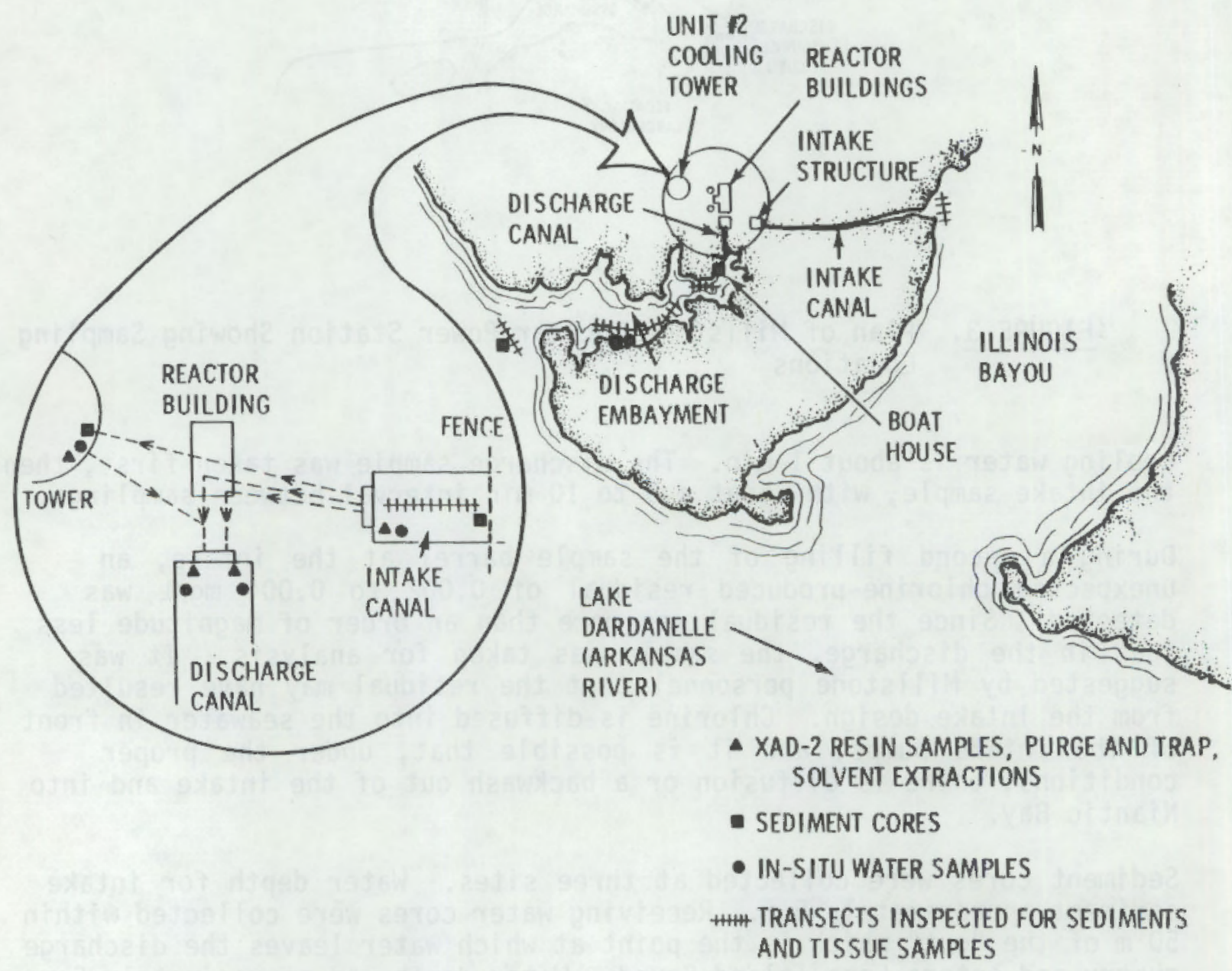

FIGURE 4. Plan of Arkansas Nuclear One Showing Sampling Locations 
chlorinated at a time. Chlorination takes place in the intake bays, behind the trash screens. Unit 2 is cooled by a recirculating closed loop system with a hyperbolic cooling tower. Chlorination, conducted twice weekly, takes place at the condensers and usually continues for $30 \mathrm{~min}$. Both units share a common intake structure and both are chlorinated with chlorine gas. The configuration of Arkansas Nuclear One, with two different cooling system designs sharing a common intake source, presented an excellent opportunity to compare the chemistry resulting from the different temperatures, mineral content, chlorine concentration, and length of chlorine exposure introduced by the design.

The two sides of Unit \#1 condensers (A and B) are completely independent. Each side uses two sets of intake bays, circulation pumps and discharge conduits (Figure 5). The Unit 2 blowdown discharges into the Unit \#1 A condenser flume $40 \mathrm{~m}$ upstream from the mouth of the discharge conduit. The barrier at the end of the discharge conduit has 4 crossover holes but total residual oxidant measurements indicated negligible mixing between the chlorinated cooling water of the $A$ and $B$ condensers.

Purge and trap, solvent extract, and XAD-2 resin samples were collected at 4 sites at the plant: intake (control), Unit \#1 discharge (chlorinated), Unit 2 blowdown (chlorinated), and a mixed discharge (chlorinated) from both

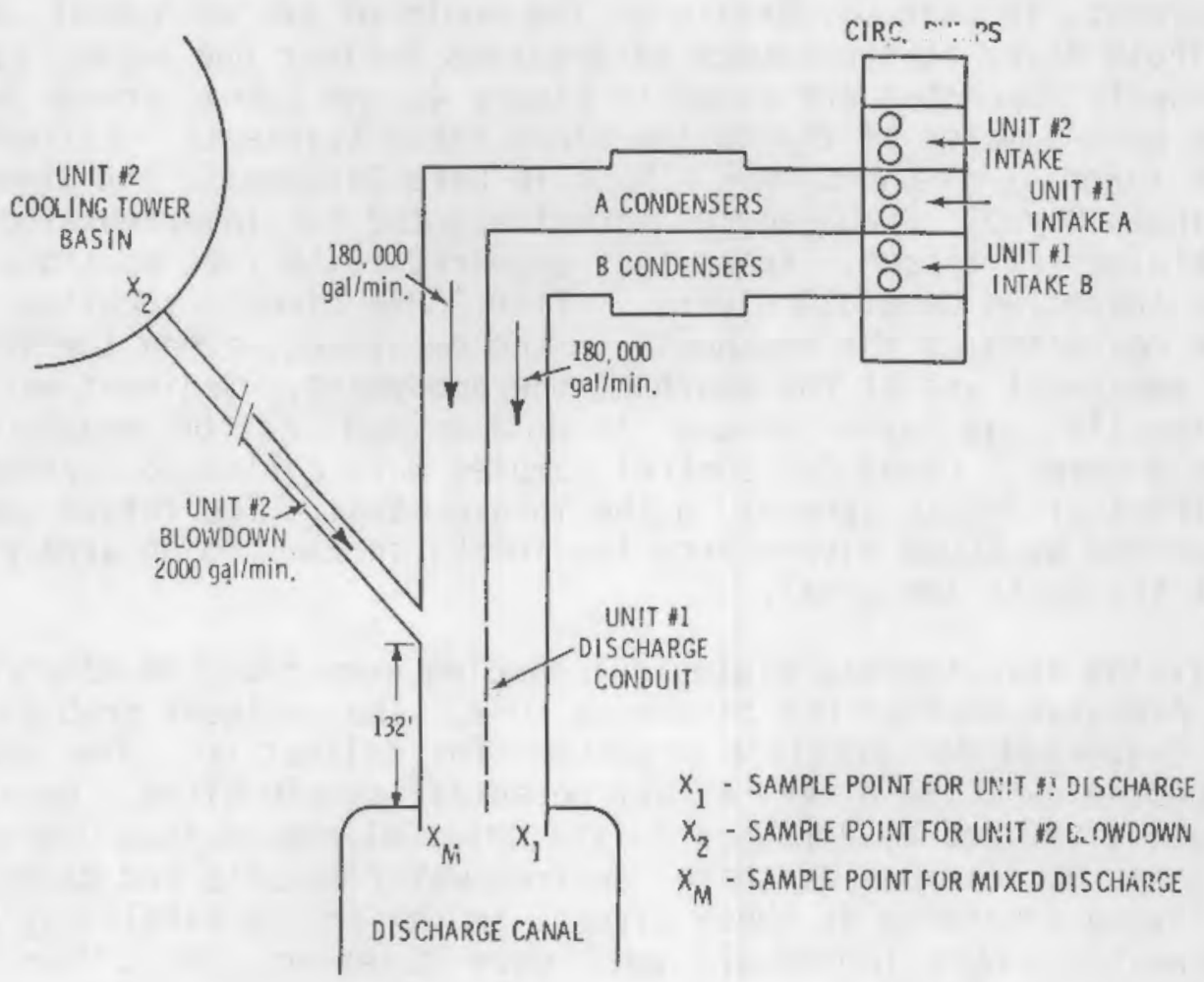

FIGURE 5. Detail of Cooling Water Systems for Arkansas Units \#1 and \#2 
units. The intake sample was taken as close as practicable to the intake structure without being in the high security area. The intake sample was pumped about $1 / 2$ to $1 \mathrm{hr}$ prior to chlorination to ensure the sample would be free of any trace amounts of chlorine resulting from diffusion of chlorine out of the intake bays. The Unit \#1 discharge sample was taken at the mouth of the discharge conduit from the B condensers, which is not mixed with the blowdown from Unit \#2. The XAD-2 sample was taken when a positive residual oxidant reading was detected. The Unit \#2 blowdown sample was taken from the cooling tower basin at the point of discharge. Sampling commenced about 30 minutes after the initial TRO was detected in the basin in order to allow the residual to reach a maximum and to allow time for thorough mixing of the chlorinated water in the closed loop mode. The mixed discharge samples was taken about 1-2 hr after chlorination of Unit \#2 (blowdown of Unit \#2 continued through this time) and during the chlorination of the A condensers of Unit \#1.

Three sediment samples were collected at each of five sites. Sediment was collected from the basin of the cooling tower for Unit \#2. Since the only accessible sediment in the basin was less than $5 \mathrm{~cm}$ deep and had a very fluid consistency, the sediment was scraped from the basin floor and poured into Lexan tubes. The bottom soil in the embayment, Lake Dardenelle and the Illinois Bayou is clay, apparently containing little organic material. Lake Dardenelle and the Illinois Bayou are backwater from the Dardenelle Dam downstream from Arkansas Nuclear One. Under the guidance of personnel from Arkansas Power and Light we inspected the sediments in the discharge embayment, in Lake Dardenelle at the mouth of the embayment, and in the Illinois Bayou at the source of Arkansas Nuclear One intake canal. The transects inspected are shown in Figure 4. An Eckman dredge was used to take grab samples of the bottom along these transects. Fifteen grab samples were taken in the embayment, four in Lake Dardenelle and three in the Illinois Bayou. Grab samples were inspected for invertebrates for sampling of biological tissue. Areas that appeared to be like possible sample sites were inspected by SCUBA divers. After SCUBA diver inspection, core samples were collected at the boathouse in the embayment, along the south shore of the embayment and at the mouth of the embayment. Sediment was not collected in the Illinois Bayou because the bottom could not be penetrated by the sample cores. Cores for control samples were collected approximately $20 \mathrm{~m}$ in front of intake screens in the intake canal. The intake canal bottom was inspected by SCUBA divers from the intake screens to an area near the fence that transects the canal.

No living invertebrate biological samples were found in the vicinity of the Arkansas Nuclear One discharge zone. The sediment grab samples were all inspected for possible organisms for collection. The bottom was inspected by SCUBA divers at all potential sample sites. We also searched a sample site used by Arkansas Polytechnic College to test the effects of Arkansas Nuclear One discharge on freshwater mussels and clams. There were no living specimens at these sites. In the intake canal only three small freshwater clams (Corbicula sp.) were observed. No other living mollusks were found. 


\subsubsection{Edwin I. Hatch Nuclear Plant, Unit \#2}

- Date Sampled: January 15-17, 1982

- Location: Baxley, Georgia (Altamaha River)

- Cooling System: Mechanical Draft

An additional sampling task was performed to measure air flow, temperature, and haloform concentration above a cooling unit before, during, and after a chlorination cycle at the Hatch plant to determine the quantity of volatile chlorinated organics lost to the atmosphere via cooling tower evaporation and drift. A plan of the Hatch plant with sampling locations is shown in Figure 6. This major additional task is described in detail in Appendix $B$.

The sampling at the Hatch facility was complicated by extreme cold (100-year low temperatures prevailed), freezing rain, and 30-40 mile/hr winds. The cold temperatures caused the pipes of the chlorination system to freeze, and added to problems created by an unscheduled shutdown of Unit \#1 turbine. As a result, cooperation which could be afforded us by plant personnel was minimal, causing additional delays in sampling preparations. After four days of effort, sampling of chlorinated water from intake and discharge water commenced on January 15. Sampling of cooling tower air and water for volatile halocarbons was conducted on January 16 and 17 . Sediment samples were not obtained, because the Altamaha River was flooding. Sediment sampling areas were under 20-25 feet of water at river flow rates in excess of 5 feet per second, and conditions were deemed too dangerous for sediment collection. Chlorination of cooling towers was conducted manually because of disabled equipment caused by freezing; hence the

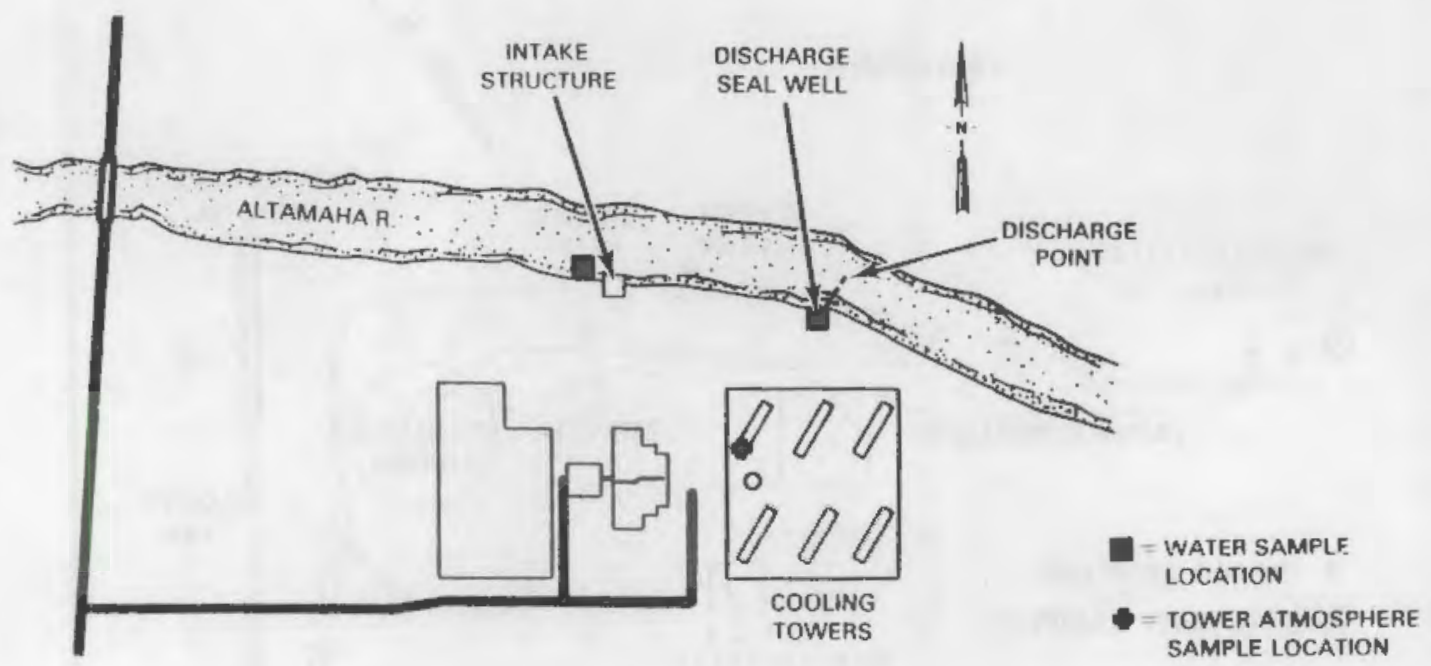

FIGURE 6. Plan of Edwin I. Hatch Nuclear Plant Showing Sampling Locations (Units \#1 and \#2 share common intake and discharge structures) 
quantity of chlorine added could only be estimated. In addition, it was found during the air sampling that there was a constant residual in the cooling tower riser water of $0.1 \mathrm{mg} / \mathrm{L}$ many hours after chlorination. The origin of this residual is not known. Service water, which is used as tower makeup water, was not being chlorinated at the time. A leak of chlorine into the tower from the disabled equipment may have caused the residual. Tower basin water was not sampled at this plant, except for those samples connected with atmospheric sampling.

\subsubsection{Beaver Valley Power Station, Unit \#1}

- Date Sampled: June 20-22, 1982

- Location: Shippingport, Pennsylvania (Ohio River)

- Cooling System: Hyperbolic Tower

The Beaver Valley normally adds gaseous chlorine to each of two condensers for one hour, following a very mild chlorination of their service water. Service water was not chlorinated the day discharge water was sampled. During chlorination, blowdown is continuously discharged without significant dilution directly into the Ohio River. Intake water was sampled $1,000 \mathrm{~m}$ upstream from the intake to avoid the possibility of contaminating the sample with cooling tower overflow which has a shoreline discharge point $800 \mathrm{~m}$ upstream from the intake. Figure 7 shows the locations of sampling points at Beaver Valley. Sediment samples were obtained about $15 \mathrm{~m}$ from shore in about $3 \mathrm{~m}$ of water. Texture of sediment was very fine at the discharge location, but coarse gravel mixed with fines at the intake location. Both bulk sediment and core sediment samples were obtained.

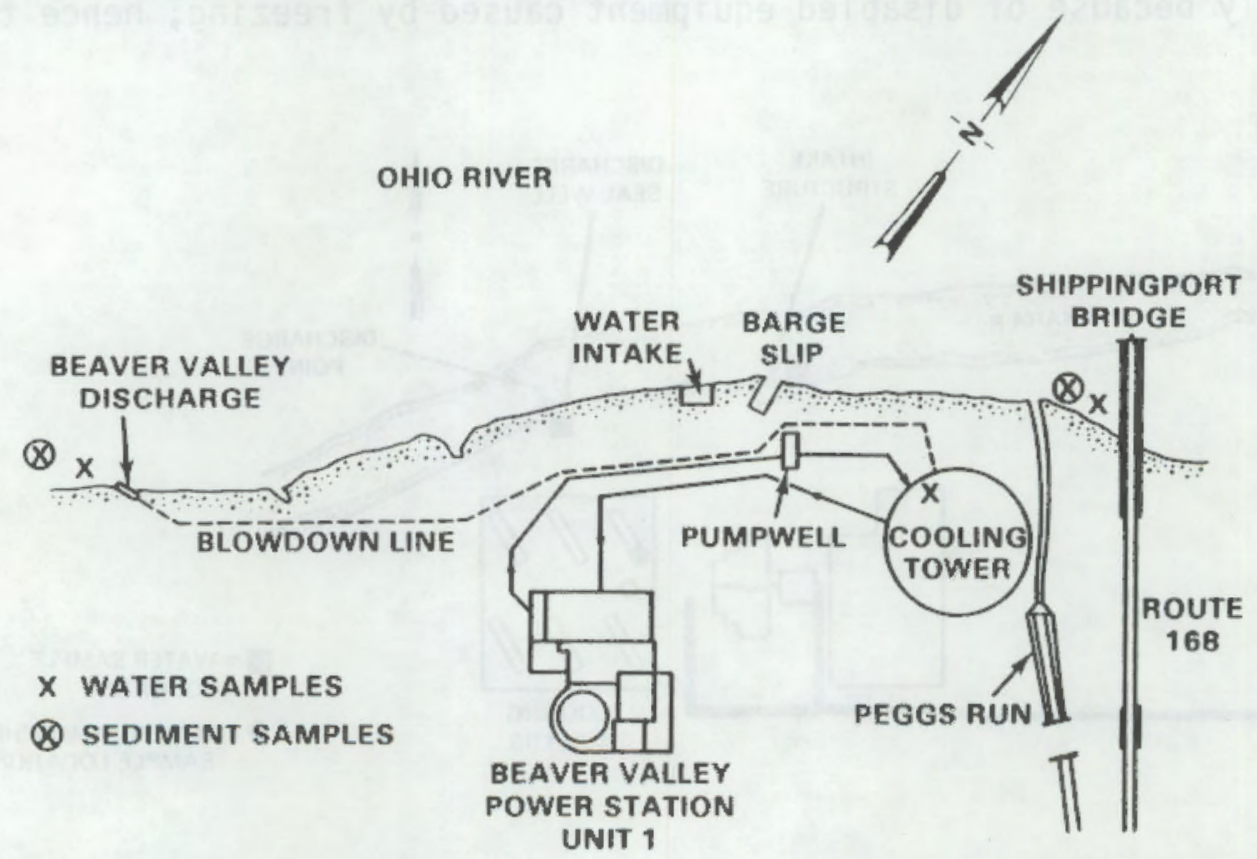

FIGURE 7. Plan of Beaver Valley Power Station, Unit \#1, Showing Sampling Locations 


\subsubsection{Trojan Nuclear Plant}

$\begin{array}{lll}\text { - } & \text { Date Sampled: } & \text { September 8-10, } 1982 \\ \text { - Location: } & \text { Rainier, Oregon (Columbia River) } \\ \text { - Cooling System: Hyperbolic Tower }\end{array}$

Just prior to our arrival at the Trojan plant, a problem in one of the two circulation pumps required a shutdown for about $24 \mathrm{hr}$. The chlorinated discharge was sampled as the plant was coming up to full power. Figure 8 shows the locations of sampling points for both water and sediment. We had been informed that the plant would stay at $60 \%$ power during our sampling; however, the power was between 65 and $90 \%$ during the time the tower was sampled, and between 90 and $100 \%$ for discharge sampling. The cooling tower has a volume of 5 million gallons, and is normally chlorinated for 30 minutes each day. The only chemical normally added to the cooling system other than chlorine is sulfuric acid for $\mathrm{pH}$ control. During chlorination of the cooling water with 250 lbs of gaseous chlorine, blowdown $(5,000 \mathrm{gpm})$ is stopped and is not discharged until the residual is not detectable (to meet zero discharge limits). Service water is chemically dechlorinated prior to discharge, but blowdown is not. During our sampling, chlorination of the circulation system was continued for one hour, $10 \mathrm{~min}$. During discharge, the blowdown is mixed with $8,200 \mathrm{gpm}$ service water. It was not possible to sample actual discharge, which emits from a diffuser in the Columbia River. The chlorinated discharge was obtained from the discharge using a sampling port located at the service water dechlorination, a point after dilution with service water had taken place. Maximum

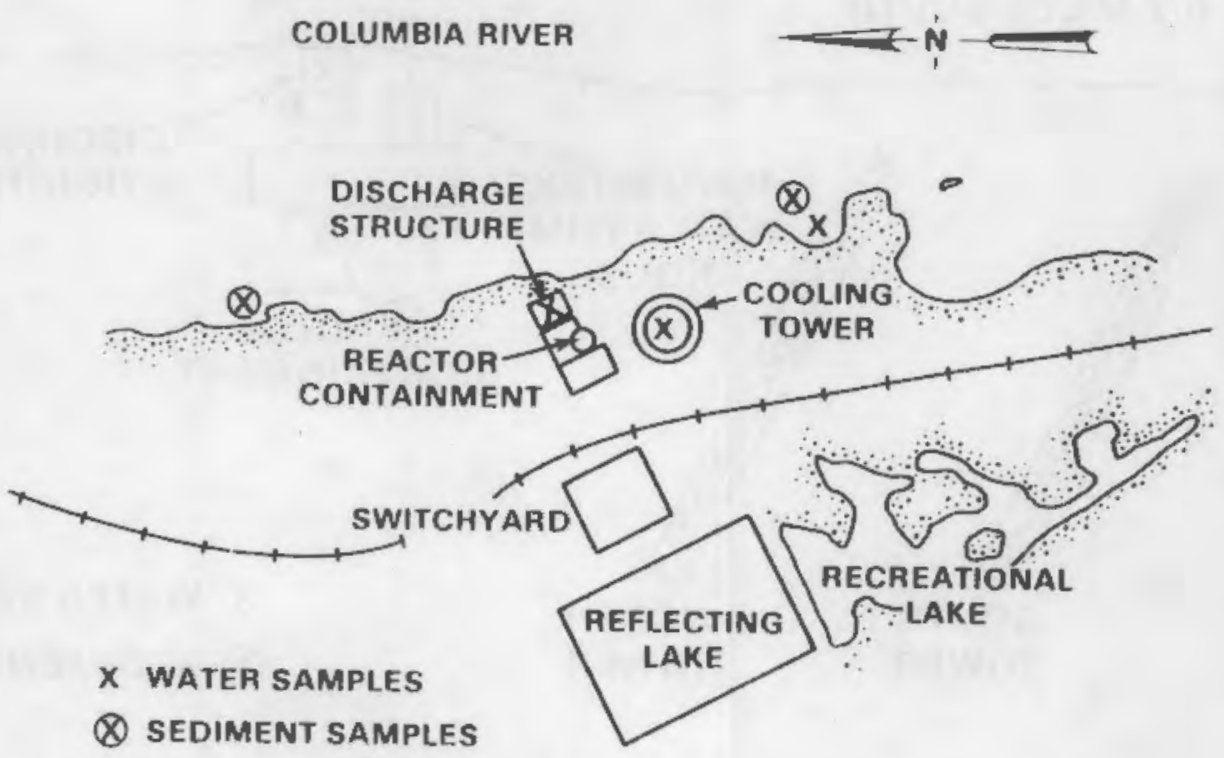

FIGURE 8. Plan of Trojan Nuclear Plant Showing Sampling Locations 
total residual chlorine in the tower basin was $0.87 \mathrm{ppm}$, and was $0.02 \mathrm{ppm}$ in the discharge. It was not physically possible to sample intake water at the intake structure. A sampling point was chosen near a barge-loading facility about $200 \mathrm{~m}$ from the intake. The discharge sediment samples were taken from a radiation monitoring location, where the discharge plume is known to impact the shore. Both bulk and core sediment samples were taken in $3 \mathrm{~m}$ of water about $15 \mathrm{~m}$ from shore.

\subsubsection{Palisades Nuclear Generating Plant}

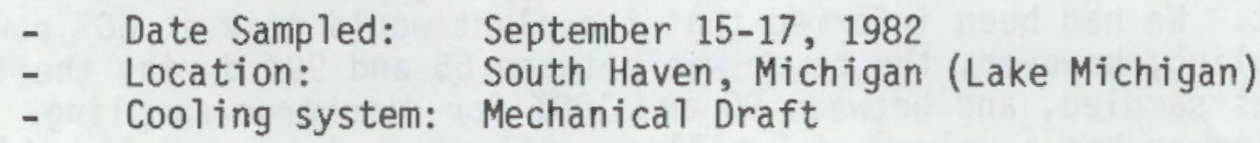

The cooling system at Palisades Nuclear Generating Plant (Figure 9) is very complex. Originally designed as a once-through cooling system, the plant is now cooled with two mechanical draft towers. The tower cooling

\section{LAKE MICHIGAN}

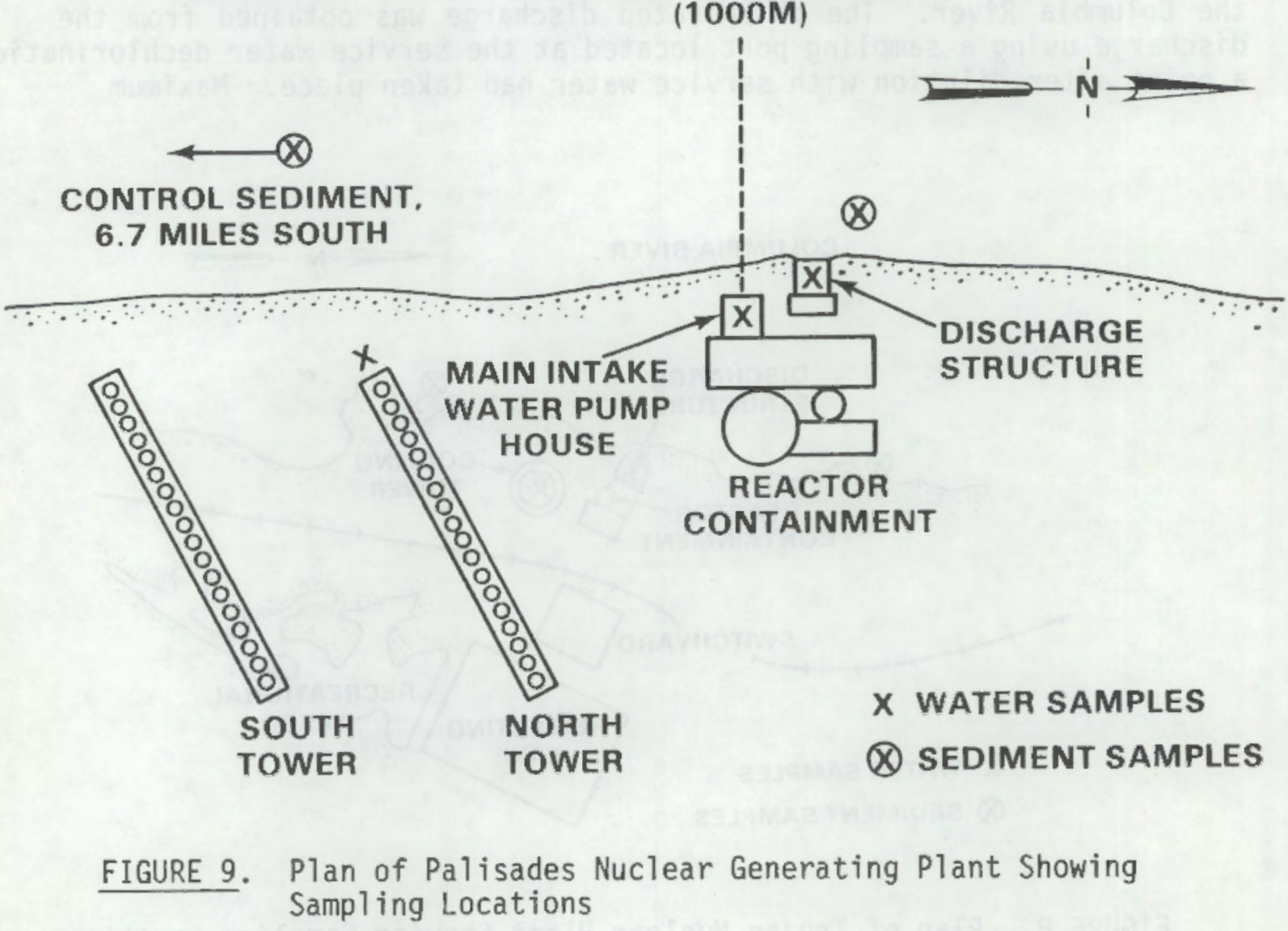


system has been revised extensively. Figure 10 shows the plan of the water circulation as presented in the Final Addendum to the Final Environmental Statement (USNRC, 1978). This design shows dilution water being added to the discharge mixing basin at $60,000 \mathrm{gpm}$ in order to lower the discharge temperature from 2,000 gpm blowdown. In actual practice, $30,000 \mathrm{gpm}$ of dilution water is added directly to each of two sides of the condenser, and for each tower servicing the condenser, $27,000 \mathrm{gpm}$ of blowdown is withdrawn and directed to the discharge mixing basin. Chlorination, performed just in front of the main condenser, is conducted daily for 40 minutes at each circuit. The discharge mixing basin accepts chlorinated blowdown, non-chlorinated blowdown, overflow from the makeup basin, and a variable quantity of additional dilution water. In addition, overflow from the makeup basin enters into the discharge mixing basin at a point opposite the discharge end. Although mixing in the discharge basin appears vigorous, it is apparent from TRC measurements, and from our chemical analyses, that the discharge water available at our access point was not well mixed, and contained a disproportionately high fraction of undiluted blowdown. There was no access for our sampling equipment at the discharge side of the mixing basin. The maximum total residual chlorine measured at the rear of the mixing basin where we sampled was $0.87 \mathrm{ppm}$ while samples taken from the

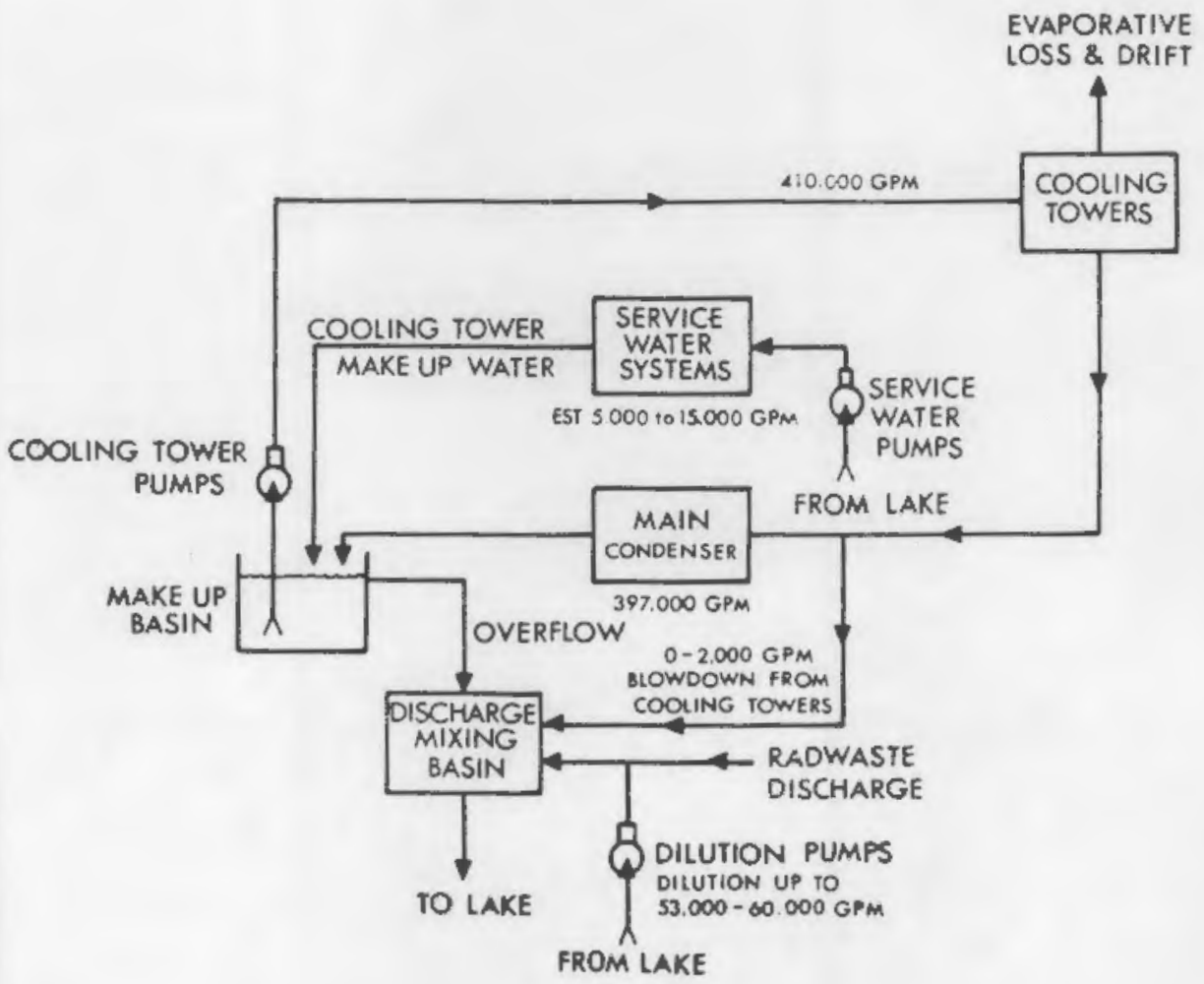

FIGURE 10. Water Circulation Plan for Palisades Nuclear Generating Plant (from USNRC, 1978) 
opposite side and measured by plant personnel did not exceed $0.1 \mathrm{ppm}$. Because the residual discharge limit for Palisades is $0.5 \mathrm{ppm}$, our discharge sample represents a somewhat higher level of chlorination than could be expected to be discharged into Lake Michigan from the Palisades facility.

Sampling of discharge and tower basin was conducted during chlorination of the north cooling tower. Figure 9 shows the sampling locations at the Palisades facility. The intake to the plant is about $1000 \mathrm{~m}$ out into the lake; thus, we drew the intake sample from a valve at the main water intake pump house. Sediment samples were easily obtained $10 \mathrm{~m}$ from shore in $2 \mathrm{~m}$ of water in the discharge plume. A control sediment sample was taken 6.7 miles south of the plant where there was public access to the lake shore. 


\section{ANALYSIS OF POWER PLANT COOLING WATERS}

The goals for the task of power plant water analysis were to identify and measure concentrations of halogenated organics present in chlorinated cooling water discharges, to determine the extent that power plant chlorination contributes to the concentrations of haloorganics discharged, and to estimate the net contribution of power plant chlorination products to the environment.

The first of the following sections discusses the changes in concentrations of anions in cooling waters brought about by plant operations. These measurements have been useful in defining plant conditions at the time of sampling, and also have helped explain some of the organohalogen chemistry observed. The sections following describe the identification and quantification of the volatile, phenolic, and base-neutral organic material, and their relative contribution to the total organic halogen as measured by the XAD-2 adsorption technique first described by Glaze et al. (1977). An important point to keep in mind is that chloramines and other $\mathrm{N}$-chlorinated organic compounds known to be formed by addition of chlorine to natural waters (Weil and Morris, 1949; Saunier and Selleck, 1976) are not determined by the methods employed in these studies; in fact, the addition of sodium sulfite insures the destruction of these active chlorine species during sampling. The chlorinated organic material analyzed are those which can be expected to be reasonably persistent in the environment, and which are lipophilic enough to be adsorbed on XAD-2 resins.

\subsection{Anions and Organic Carbon}

\section{1 .1 Methods}

The analysis of anions by ion chromatography (Dionex Model 16 Ion Chromatograph) have been described previously (Bean et al., 1980). Improvements in instrumentation and in resolution took place between the first set of samples in 1980 and the second set obtained in 1982, and interferences with the analyses in early samples were not a problem in later samples. Organic carbon was determined after removal of inorganic carbonate by acidification. A Dohrman Model DC-80 Carbon Analyzer was used for the determination.

\subsubsection{Results}

The concentration of anions and organic carbon for the various power plant cooling water streams are presented in Table 3 . As one might expect, anion concentrations did not change between intake and discharge of Millstone and Arkansas Unit \#1, which are once-through cooling units. Changes in concentrations of anions were marked in most cooling systems employing cooling towers, because water evaporation from the towers creates a concentrated solution in the tower basins. 
TABLE 3. Analys is of Power Plant Waters for Anions and Organic Carbon (Values Given in $\mathrm{mg} / \mathrm{L}$ of Water)

\begin{tabular}{|c|c|c|c|c|c|c|c|}
\hline & $\mathrm{SO}_{4}{ }^{2-}$ & $\mathrm{F}^{-}$ & $\mathrm{Cl}^{-}$ & $\mathrm{Br}^{-}$ & $\mathrm{NO}_{3}^{-}$ & $\mathrm{PO}_{4}{ }^{3-}$ & Organic C \\
\hline \multicolumn{8}{|l|}{ Duane Arnold } \\
\hline Intake & 215 & (a) & 18 & $<0.2(c)$ & 36 & 0.4 & 12 \\
\hline Discharge & 997 & (a) & 80 & $\leq 1.0$ & 144 & 1.8 & 18 \\
\hline \multicolumn{8}{|l|}{ Millstone } \\
\hline Intake & 2280 & (a) & 16190 & 57.4 & $<1$ & (b) & 1.7 \\
\hline Discharge & 2370 & (a) & 16210 & 57.6 & $<1$ & (b) & 9 \\
\hline \multicolumn{8}{|l|}{ Arkansas } \\
\hline Intake & 66.5 & 0.27 & 126 & 0.19 & 0.22 & 0.05 & 26.3 \\
\hline Unit \#1 Disch. & 74.9 & 0.28 & 125 & 0.18 & 0.08 & 0.06 & 24.3 \\
\hline Unit \#2 Disch. & 903 & 1.25 & 761 & 1.02 & 3.10 & $<0.1$ & 12.9 \\
\hline Mixed Disch. & 86.7 & 0.32 & 138 & 0.17 & 0.27 & -0.07 & 25.2 \\
\hline \multicolumn{8}{|l|}{ Edwin Hatch } \\
\hline Intake & 9.6 & 0.06 & 4.5 & 0.02 & 1.09 & 0.04 & 5.7 \\
\hline Tower & (d) & 0.12 & 11.2 & 0.02 & 0.34 & 0.05 & (a) \\
\hline Discharge & 11.5 & 0.08 & 7.0 & 0.02 & 0.88 & 0.04 & 10.8 \\
\hline \multicolumn{8}{|l|}{ Beaver Valley } \\
\hline Intake & 91 & 0.22 & 27.1 & 0.10 & 6.82 & 0.07 & 2.7 \\
\hline Tower & 103 & 0.25 & 29.2 & 0.08 & 5.66 & 0.18 & 2.5 \\
\hline Discharge & 106 & 0.25 & 29.6 & 0.07 & 4.94 & 0.21 & 14.0 \\
\hline \multicolumn{8}{|l|}{ Trojan } \\
\hline Intake & 8 & 0.09 & 5.6 & 0.01 & 0.86 & 0.08 & 12.9 \\
\hline Tower & 141 & 0.32 & 19.9 & 0.01 & 1.50 & 0.18 & 13.8 \\
\hline Discharge & 23 & 0.12 & 6.0 & 0.01 & 0.80 & 0.09 & 14.4 \\
\hline \multicolumn{8}{|l|}{ Pal i sades } \\
\hline Intake & 23 & 0.12 & 10.2 & 0.02 & 1.07 & 0.03 & 2.1 \\
\hline Tower & 88 & 0.14 & 15.2 & $\leq 0.01$ & 1.06 & $<0.05$ & 2.9 \\
\hline Discharge & 77 & 0.13 & 14.0 & $\leq 0.02$ & 0.99 & $\leq 0.05$ & 9.8 \\
\hline
\end{tabular}

(a) Not determined

(b) Interference by $\mathrm{Cl}^{-}$precluded determination by ion chromatography

(c) Nitrate interfered with $\mathrm{Br}^{-}$analysis

(d) Determined on a purge-and-trap sample to which sulfite had been added, hence $\mathrm{SO}_{4}{ }^{2-}$ analys is is meaningless

Sulfate increases of more than an order of magnitude between intake and cooling tower basin are observed for Arkansas Unit \#2 and Trojan, which can be explained by the practice of adding sulfuric acid in cooling towers to lower the alkalinity. At the Palisades plant, increases in sulfate concentration were detected that were higher than the increases in chloride and fluoride ions in both cooling tower and discharge. This indicates that acid was being used, and that the discharge sample was not diluted particularly well at our sampling point (see Section 2.2.7). The lack of dilution is also indicated by noting that the fluoride and chloride ions are also just slightly less than the tower sample.

The increases in ion concentrations in the cooling tower basin can be used to determine the relative amount that the intake water has been concentrated through the evaporative cooling process. Fluoride ion concentration increases were used to calculate this concentration factor (CF). The results are presented in Table 4 and are compared to the CF's calculated from blowdown and drift specifications. Fluoride ion was not 
determined for the Duane Arnold plant; the CF listed was calculated from chloride ion. Although the addition of chlorine as biocide should make the calculation of CF higher than actual, errors introduced by chlorine addition are minimized in this case because of the relatively large contribution of unchlorinated makeup water to the total ion concentration. As noted in Table 4, the CF given for the Duane Arnold plant is consistent with that calculated from other ions, and is somewhat less than calculations based on phosphate or sulfate. The concentration factor at the Duane Arnold plant based on design data is much lower than achieved by actual plant practice, because blowdown is not discharged for 8 to $12 \mathrm{hr}$ after chlorination, and thus CF is a function of the length of time blowdown is stopped. With the exception of the Duane Arnold plant, CF's measured by ion concentration are in reasonable agreement with the calculated value.

Bromide ion was interfered with by the large concentration of nitrate ion in the Duane Arnold plant cooling system. The other bromide data shows that bromide concentrations in cooling tower basin water were not significantly higher than in intake water except in Arkansas Unit \#2, where the bromide increased about as much as the CF would indicate it should. Bromide was not concentrated in Trojan or Hatch tower basins $(\mathrm{CF}=2$ and 3.6 , respectively); however, initial concentrations were very low. It is possible that at very low bromide concentrations, oxidation of $\mathrm{Br}^{-}$to $\mathrm{Br}_{2}$ by added chlorine results in sufficient losses by reaction with organics and by volatilization to offset the concentrating effect of the tower. Another factor that makes bromine concentration data difficult to interpret with respect to organic reaction products is the possibility of the presence of bromine in the chlorine used as a biocide.

\section{TABLE 4. Concentration Factors (CF) in Cooling Towers at Nuclear Power Plants}

\begin{tabular}{lcc}
\hline & $\begin{array}{c}\text { Determined From } \\
\text { Fluoride Concentration } \\
\text { Ratio (Tower/Intake) }\end{array}$ & $\begin{array}{c}\text { Calculated From } \\
\text { Blowdown and Drift } \\
\text { Discharge Specifications }\end{array}$ \\
\hline Duane Arnold & $4.4^{\text {(b) }}$ & $2.75^{(c)}$ \\
Arkansas Unit \#2 & 4.6 & 5.00 \\
Hatch Unit \#2 & 2.0 & 2.16 \\
Beaver Valley Unit \#1 & 1.1 & 1.57 \\
Trojan & 3.6 & 3.30 \\
Palisades & 1.2 & 1.27 \\
\hline
\end{tabular}

(a) $\quad \mathrm{CF}=\frac{\text { (Blowdown Rate) }+ \text { (Drift and Evap. Rate) }}{\text { Blowdown Rate }}$

(b) Fluoride ion not measured. $C F=4.4$ based on chloride, 4.5 based on phosphate, 4.0 based on nitrate, and 4.6 based on sulfate.

(c) Blowdown is stopped for up to 12 hours to allow $\mathrm{Cl}$ residual to dissipate. This explains the larger measured CF. 
The results for nitrate, phosphate and organic carbon do not lend themselves to facile interpretation. Trends for nitrate and phosphate are not consistent. Nitrate concentration was very high in the Duane Arnold plant discharge, probably because the area is extensively farmed, and the Cedar River is affected by agricultural runoff. All of the discharge samples had higher organic carbon than the intake (exception Arkansas Unit \#1), and many had higher organic carbon in the (diluted) discharge than in the tower. An explanation for this result is not immediately apparent.

\subsection{Haloforms and Other Volatile Halogenated Organics}

\subsubsection{Method}

The purge-and-trap method for analysis of volatile organics in water (Bellar and Lichtenberg, 1974) was documented during previous studies of water chlorination products (Bean et al., 1980). The method is extremely sensitive and can be performed on a few milliliters of water samples with a sensitivity of less than one $\mu \mathrm{g} / \mathrm{L}$ (part-per-bilition). The procedure as used for these studies involves ysing a flow of nitrogen to sparge a $20 \mathrm{~mL}$ water sample into a Tenax polymer trap. The volatiles, adsorbed on the trap, are then heated in a flow of helium directed to a chromatography column, separated by gas chromatography, and analyzed by mass spectrometry.

The mass spectrometric data is then searched for the compounds listed in Table 5 by scanning the appropriate reconstructed single ion mass chromatograms. If a characteristic mass peak is located at the retention time appropriate for a compound of interest (Table 5), the entire spectrum of the compound at that retention time is obtained to confirm its presence in the sample. Quantitation of the identified compounds were made by determining areas under the peaks of appropriate single ion scans and comparing to areas obtained from standards. In a departure from previous practice, bromocyclohexane (retention time, 31.5; characteristic mass, 83) was used as an internal standard. The internal standard was added to the water sample immediately prior to purging the sample with nitrogen. The sensitivity of the method, while always high, varied an order of magnitude depending on the condition of the mass spectrometer source. Thus, the detection limit for most compounds varied between 0.1 and $0.01 \mu \mathrm{g} / \mathrm{L}(\mathrm{ppb})$.

\subsubsection{Results and Discussion}

The volatile analysis of the waters collected at the seven power plants are shown in Table 6 . Bromoform was the principal volatile compound found in the once-through discharge at the Millstone plant. The concentration found, about $4 \mu \mathrm{g} / \mathrm{L}$, is comparable with the $15 \mu \mathrm{g} / \mathrm{L}$ concentrations we have found in other chlorinated seawater samples at Sequim Bay, Washington and San Onofre, California (Bean et al., 1980), and Redondo, California (Bean et al., 1982), if the dilution of the Millstone discharge is taken into account. Millstone chlorinates one of 
TABLE 5. Volatile Compounds Searched for in Purge and Trap Analysis

\begin{tabular}{lcc}
\hline \multicolumn{1}{c}{ Compound } & $\begin{array}{c}\text { Retention Time } \\
\text { (min) }\end{array}$ & $\begin{array}{c}\text { Mass Used } \\
\text { for Search }\end{array}$ \\
\hline 1,1-Dichloroethylene & 10.5 & 61,98 \\
1,1,-Dichloroethane & 11.7 & 63 \\
1,2-Dichloropropane & 17.2 & 63 \\
1,3-Dichloropropane & $17.7,19.0$ & 75 \\
(cis + trans) & 8.3 & 84 \\
Methylene chloride & 16.0 & 85 \\
Dichlorobromomethane & 13.2 & 85 \\
Chloroform & 25.4 & 131,83 \\
1,1,2,2-Tetrachloroethane & 12.5 & 96,98 \\
1,2-Dichloroethylene & 13.8 & 112 \\
Ch-Dichloroethane & 31.3 & 97 \\
Chlorobenzene & 14.8 & 117 \\
Carbon tetrachloride & 15.2 & 127 \\
Chlorodibromomethane & 18.8 & 130 \\
Trichloroethylene & 18.1 & 166 \\
Tetrachloroethylene & 25.5 & 173 \\
Bromoform & 21.7 & \\
\hline
\end{tabular}

four condensers at a time; hence, the effluent is always diluted $4: 1$. The almost exclusive formation of bromoform from chlorination of seawater has been widely reported (Carpenter and Smith, 1978; Bean et al., 1978; Helz and Hsu, 1978). The bromide ion in natural seawater (see Table 3 ) is readily oxidized by added chlorine to bromine, which is the dominant halogen reagent in seawater chlorination. In contrast, chloroform was the only volatile component found in the discharge of the Duane Arnold plant, and was the predominant haloform product at Hatch, Beaver Valley, Palisades, and Trojan facilities. These results are consistent with those reported in our earlier study of ten different water bodies across the U.S. (Bean et al., 1980). The bromine incorporation into the haloform products from both Arkansas Unit \#1 and Unit \#2 was extensive and reflects the relatively high bromide ion concentration found in the cooling waters sampled (Table 3 ).

The data in Table 6 indicates that cooling towers can have an influence on the composition and concentration of haloforms in the discharge. A direct comparison between once-through and tower operation is possible with the Arkansas data. For Unit \#1 the total haloforms ranged from 2.7 to $4.8 \mu \mathrm{g} / \mathrm{L}$ (contribution of haloforms from Unit \#2 can be neglected in the mixed discharge from Unit \#1). For Unit \#2, the unit cooled with a hyperbolic tower, the concentration of haloform was found to be only $2.4 \mu \mathrm{g} / \mathrm{L}$ in spite of the very much higher level of chlorine addition in the tower ( $\sim 4 \mathrm{mg} / \mathrm{L}$, tower; $\sim 0.3 \mathrm{mg} / \mathrm{L}$, once-through). Further, the product distribution of haloforms are different in the discharges from the two Arkansas units: Unit \#2 (tower) has equal concentrations of 
TABLE 6. Analysis of Water Samples for Volatiles by Purge-and-Trap (Values Given in $\mathrm{mg} / \mathrm{L}$ of Water)

\begin{tabular}{|c|c|c|c|c|c|c|c|c|c|c|c|}
\hline \multirow[t]{2}{*}{ Compound } & \multicolumn{2}{|c|}{ Millstone } & \multicolumn{2}{|c|}{ Duane Arnold } & \multicolumn{4}{|c|}{ Arkansas } & \multicolumn{3}{|c|}{ Hatch } \\
\hline & Intake & Discharge & Intake & Di scharge & Intake & $\begin{array}{l}\text { Disch. } \\
\text { Unit \#1 }\end{array}$ & $\begin{array}{l}\text { Disch. } \\
\text { Unit \#2 }\end{array}$ & $\begin{array}{c}\text { Mixed } \\
\text { Discharge }\end{array}$ & Intake & $\begin{array}{l}\text { Tower } \\
\text { Riser }\end{array}$ & Discharge \\
\hline Chloroform & & & $0.4,0.5$ & & $0.15,0.15$ & $1.08,1.05$ & $0.71,0.69$ & $2.04,1.61$ & & $15.61,11.98$ & $0.77 \pm .09$ \\
\hline Bromodichloromethane & & & & & & $1.03,0.97$ & $0.69,0.67$ & $1.90,1.82$ & & $0.61,0.41$ & \\
\hline Dibromochloromethane & & $0.2 \pm 0.1$ & & & & $0.61,0.64$ & $0.74,0.83$ & $1.03,1.04$ & & & \\
\hline Bromoform & & $3.7 \pm 0.6$ & & & & $0.05,0.05$ & $0.19,0.26$ & $0.06,0.07$ & & & \\
\hline 1,2-0ichloropropane & & & & & 0.2 & 0.2 & 0.2 & 0.2 & & & \\
\hline Tetrachl oroethyl ene & & & & & 3.1 & 2.5 & 2.5 & 2.7 & & & \\
\hline
\end{tabular}

1,1-Dichloroethylene 1,2-0ichloroethane 1,1-Dichloroethane Dichloromethane Chloroform

Bromodichloromethane 1,2-Dichloroethylene

1,1,1-Trichloroethane Carbon tetrachloride Dibromochloromethane Trichloroethylene

Tetrachl oroethyl ene Bromoform
Beaver Valley

Intake

tr, tr $0.01,0.01$ $0.03,0.01$ $0.1,0.1$ $0.29,0.26$ $0.01,0.03$ $0.13,0.12$ $0.09,0.09$

$0.04,0.01$ $0.17,0.18$ $0.09,0.09$ $\mathrm{tr},-$

0.03

0.1

1.5

0.15

tr

0.14
0.01
(b)
0.03

0.03

Tower $^{(a)}$ Discharge

$0.12,0.03$

0.7 ,-

$0.06,0.06$

$0.17,0.18$

$6.0,6.3$

$0.6,0.7$

$0.01,-$
$0.09,0.10$

$0.02,0.01$

(b)

(b)

$0.03,0.03$

$0.05,0.06$

$0.01,0.01$

$0.05,0.06$
$0.02,0.02$
$0.53,0.53$
$2.6,3.2$

$0.26,0.24$

tr, 0.01

$0.11,0.14$

$02,0.02$

$0.03,0.02$

$0.02,0.01$
Palisades

Tower

Discharge

(a) Purge-and-trap samples lost through breakage; bulk water sample analyzed (see text)

(b) Between 0.1 and $0.2 \mu$ 
chloroform, bromodichloromethane, and dibromochloromethane, while only the first two predominate in the Unit \#1 discharge. Also, bromoform in Unit \#2 tower is 3 to 4 times the concentration found in the Unit \#1 discharge. The shift in composition toward the brominated haloforms in the tower basin can arise from the higher levels of bromide ion in the Arkansas tower water (Table 3), preferential loss of the more volatile haloforms by evaporation or drift, or a combination of both.

The data in Table 6 suggests that haloform products of chlorination are lost by evaporation in cooling towers. The high concentration of chloroform in the Edwin Hatch tower riser (after chlorination, but before evaporation or complete mixing with tower basin water) is in contrast to the low concentration actually found in the discharge. Further, most of the undiluted tower basin samples (Duane Arnold, E. I. Hatch, Beaver Valley, Palisades) had chloroform concentrations of $1 \mu \mathrm{g} / \mathrm{L}$ or less, while we had previously determined that the range for chloroform production from a variety of chlorinated water samples (Bean et al., 1980) was from 2 to $25 \mu \mathrm{g} / \mathrm{L}$. A direct comparison of haloforms produced from experimental chlorination of natural waters in 1978-1979 and from power plants sampled in 1982 has been made in Table 7 for three cases where the water sources are common. These results indicate that proportionately lower haloform concentrations are produced by the power plants compared with the same water bodies chlorinated without evaporative cooling.

The data in Tables 6 and 7 suggest that a considerable fraction of haloforms produced by biocide chlorination is lost to the atmosphere, therefore, measurement was conducted of the haloform concentrations in the atmosphere above the cooling tower of the Edwin Hatch plant. The protocol, methodology, and experimental results are given in Appendix $B$. The results of this study indicated that over $80 \%$ of the haloform produced was lost to atmosphere in the mechanical draft tower of the Hatch plant. Smith et al. (1983), in a study of three tower cooled fossil-fuel power plants, measured concentrations in tower risers and tower basins. Their data indicated that $20-30 \%$ of the chloroform produced by chlorination is lost to atmosphere per pass through the tower. This observation is consistent with the work of Jolley et al. (1978), who also postulated that much of the haloform for media recirculating cooling towers is lost to the atmosphere.

The data obtained for the non-haloform organohalogen volatiles indicate that in general, the water bodies used for cooling these power plants are relatively free from volatile pollutants. In addition, our data indicate that power plants do not produce non-haloform volatile chemicals at any measurable levels as a result of their biocide operations. The data for the Beaver Valley plant (Table 6) suggest that volatile pollutants in the intake water are lost to the atmosphere during passage through the cooling tower, since dichloroethane, 1,2-dichloroethylene and 1,1,1-trichloroethylene were found in the intake water, but not in cooling tower basin or discharge water. 
TABLE 7. Comparison of Haloform Production:

Cooling Towers Data Versus Experiments Conducted in 1978-1979(a)

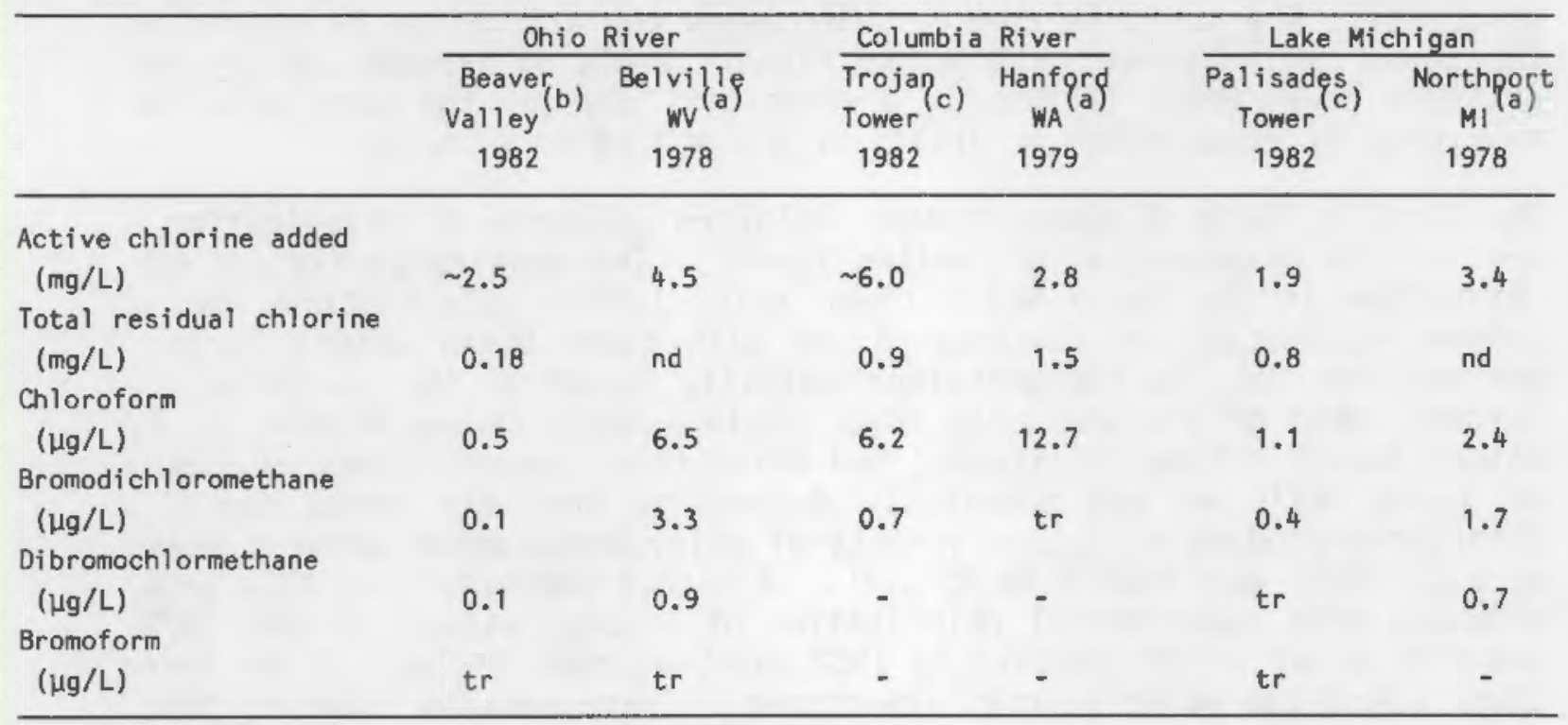

(a) Bean et al., 1980

(b) Undiluted tower blowdown sample

(c) Tower basin sample

The apparent losses of haloforms and possibly other volatile halogenated organics to the atmosphere, might be considered to be a transfer of a potential water problem to one of atmospheric pollution. While the consequences in terms of fate and environmental impact of atmospheric injection of haloforms by cooling towers are not completely known, available data (Dilling et al., 1976; Helz and Hsu,) suggest that the residence time for chloroform in the is only a few days.

\subsection{Halogenated Phenols}

Our previous work (Bean et al., 1980) demonstrated that chlorinated and brominated phenols are among the products of low-level water chlorination. For those earlier studies, phenols were recovered from XAD-2 water extracts by eluting the XAD columns with $0.1 \mathrm{~N}$ sodium carbonate. The phenols were then isolated as their acetates by adding acetic anhydride directly to the carbonate extract after the method of Krijgsman and Van de Camp (1977). Results of these investigations were not quantitative, since neither the extraction efficiency of the XAD column for phenols from the water, nor the recovery efficiency of the carbonate extraction procedure was determined. The data we obtained indicated that phenol concentrations were only a few nanograms per liter of water.

For the present studies of power plant waters, an additional set of methylene chloride extracts were taken in addition to taking large 
volume XAD-2 samples. The plan was to use the XAD extracts to obtain sufficient material for GC/MS identification, and to quantify the phenols in the methylene chloride extracts by electron capture capillary gas chromatography, after Krijgsman and Van de Camp (1977). Although electron capture detection is an extraordinarily sensitive method, quantification of the chromatographic peaks is only possible if the peak identity is known because responses in the electron capture detector vary over many order of magnitude, depending on the number, type and position of the halogen atoms.

The combination of $X A D$ and solvent extraction methods did result in the analysis of a number of phenolic compounds in power plant cooling waters, as reported below. In addition, we learned from our experiments that the sodium carbonate extraction procedure used in the previous study recovered less than $5 \%$ of the halogenated phenols from the XAD columns. Phenols were not recovered when the carbonate extracted columns were subsequently extracted with ether, therefore, it is likely that the XAD-adsorbed phenols were changed to their sodium salts by the carbonate solution, but remained bound to the XAD-2 column. Changes in the XAD-2 extraction procedure (the phenols are first removed with ethyl ether before being isolated as their sodium salts) has eliminated problems of phenol recovery.

\subsubsection{Methods}

The scheme used for isolating halogenated phenols from both XAD-2 and methylene chloride extracts is shown in Figure 11. One- or two-liter water

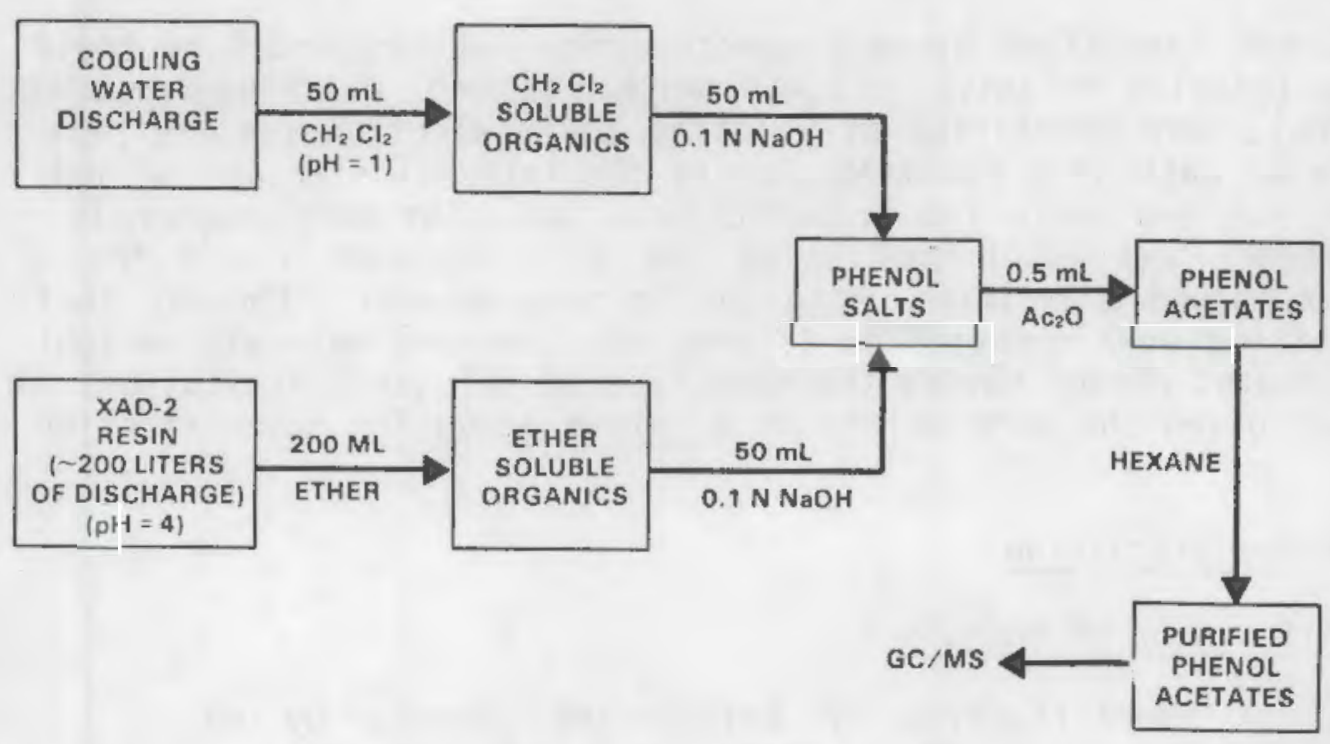

FIGURE 11. Scheme for Analysis of Power Plant Water for Halogenated Phenols 
samples from the PVC-lined sample barrels were extracted twice with $25 \mathrm{~mL}$ Burdick and Jackson methylene chloride after acidification to a $\mathrm{pH}$ of 1 to 2. A large volume water sample taken from the same barrel by pumping through XAD-2 columns was used for both phenol analysis and for the total organic halogen determinations discussed in Section 3.4. The XAD samples were extracted with $200 \mathrm{~mL}$ freshly distilled Mallinckrodt ethyl ether (this is the only ether found to be completely free from chloroform as a contaminant). After subsampling for total organic halogen and haloform analysis, the ether extract was extracted once with $50 \mathrm{~mL} 0.1 \mathrm{~N} \mathrm{NaOH}$. The $\mathrm{NaOH}$ solution was shaken with $0.5 \mathrm{~mL}$ acetic anhydride for one minute, and extracted into $4 \mathrm{~mL}$ hexane, using an additional $\mathrm{mL}$ for a wash. The concentration of $\mathrm{NaOH}$ and the relative proportion of $\mathrm{NaOH}$ and acetic anhydride are critical to good analytical recoveries. The hexane extract, evaporated to one $\mathrm{mL}$ volume in $\mathrm{n}$-heptane was then analyzed for phenols by $\mathrm{GC} / \mathrm{MS}$. As shown in Figure 11, the halogenated phenols are isolated from the methylene chloride extracts using the same acetate derivitization procedure. The final $n$-heptane concentrate is analyzed by electron capture capillary gas chromatography, using 1,3-dichlorobenzene as internal standard.

Chromatographic separation of the phenols was accomplished with a $60 \mathrm{~m}$ SP 2100 fused silica capillary column using a Hewlett-Packard Model $5840 \mathrm{~A}$. gas chromatograph. Conditions were: $70^{\circ} \mathrm{C}$ for $4 \mathrm{~min}$, programming to $250^{\circ} \mathrm{C}$ at $4^{\circ} \mathrm{C} / \mathrm{min}$. Detection of peaks was accomplished either with a Hewlett-Packard 5895 GC/MS system with 7920 disc drive, or with a Hewlett-Packard electron capture detector. Mass spectra were collected from mass 105 to 400 at approximately one second per scan. Most mass spectrometry was performed in the electron impact mode, but some spectra were determined using methane chemical ionization.

Phenolic compounds identified by mass spectrometry and documented by their retention time (usually relative to 2,4,6-trichlorophenol which was present in most samples), were quantified by relating their electron capture peak areas to those of authentic standards, using the internal standard method. Standards were not available for bromodichloro- and dibromochiorophenols. Bromodichlorophenol was quantified using the trichlorophenol, and the dibromochloro compound quantified using the trichlorophenol. Phenols that were not identified were reported as if they had the same molecular weight as the unsubstituted phenol having the same type of halogen substitution. A nitro group was given the same weight as a chloro group for quantification purposes.

\subsubsection{Results and Discussion}

\subsubsection{Identification of Phenols}

Methods used for identification of halogenated phenols by mass spectrometer have been discussed in detail in a previous report (Bean et al., 1980). The phenol acetates give a characteristic spectrum consisting of a molecular ion, $\mathrm{M}^{+}$, and an $\mathrm{M}-42^{+}$ion, which results from a loss of ketene from the acetate. The $M-42^{+}$ion is the same molecular 
weight as the original phenol (before acetylation). An illustration of the spectrum obtained from a halogenated phenol is given in Figure 12, which also illustrates the isotopic distribution patterns that allow for the identification of both the number and types of halogen substitution. Figure 12 shows the isotope pattern for a dibromophenol: i.e., a peak flanked two mass units on either side by peaks about half its height $(M-42=$ $250,252,254 ; M=292,294,296)$. All other possible combinations of chlorine and bromine have different isotopic patterns, permitting the facile assignment of halogen number and type to each phenol. In sum, the isotopic ratio, molecular ion, and $\mathrm{M}-42$ ion are tools for the specific identification of a halogenated phenol when no other substituents are present. The presence of other substituents substantially complicate the task of exact identification of a halogenated phenol.

The phenols identified by GC/MS are listed in Tables 8 and 9 . Examples of the mass spectra obtained from the halogenated phenols found are given in Appendix C. In the 1980 studies (Table 8), only phenol samples from chlorinated water were examined by GC/MS, although both intake and chlorinated waters were analyzed by electron capture gas chromatography. Both intake and discharge XAD-2 samples were examined by GC/MS for the 1982 samples (Table 9). As can be determined from an inspection of the data, a relatively large number of different mono-, di-, and trisubstituted phenols were found in the chlorinated waters. A few spectra were obtained that suggested that tetrahalophenols were also formed, but quality of spectra was not sufficiently good to confirm this. Both bromine and chlorine substitution were found, and molecules with both chlorine and bromine substitution were common. Although most of the compounds found were simple halogenated phenols, methyl-substituted chlorophenols were found in the chlorinated waters of four of the locations studied, and methylsubstituted bromophenols were found at Millstone and Arkansas where the bromide ion concentrations were relatively high. Figure 13 gives an example of the spectra of a methyl-substituted halogenated phenol. Halogenated nitrophenols were also found the chlorinated waters of five of the eight operating units we studied, brominated nitrophenols at two locations (possibly a third) and chiorinated nitrophenols at four locations. Figure 13 gives an example of the spectra obtained from a nitrohalogenated phenol.

In contrast to the chlorinated waters examined, the intake water samples contained a limited number of chlorinated phenols. A few brominated phenols were found in the Trojan intake water and tribromophenol found in the Palisades intake. It is apparent from the GC/MS data that addition of chlorine greatly adds to the number of halogenated phenols in the cooling water systems of the power plants.

In addition to the halogenated phenols listed in Tables 8 and 9 , the GC/MS analysis revealed that non-halogenated phenols were present in all of the intake and chlorinated power plant waters we examined. In addition to phenol itself, unhalogenated mono-, di-, and trimethyl phenols were found in all samples. Figure 13 shows single ion chromatograms obtained from some 

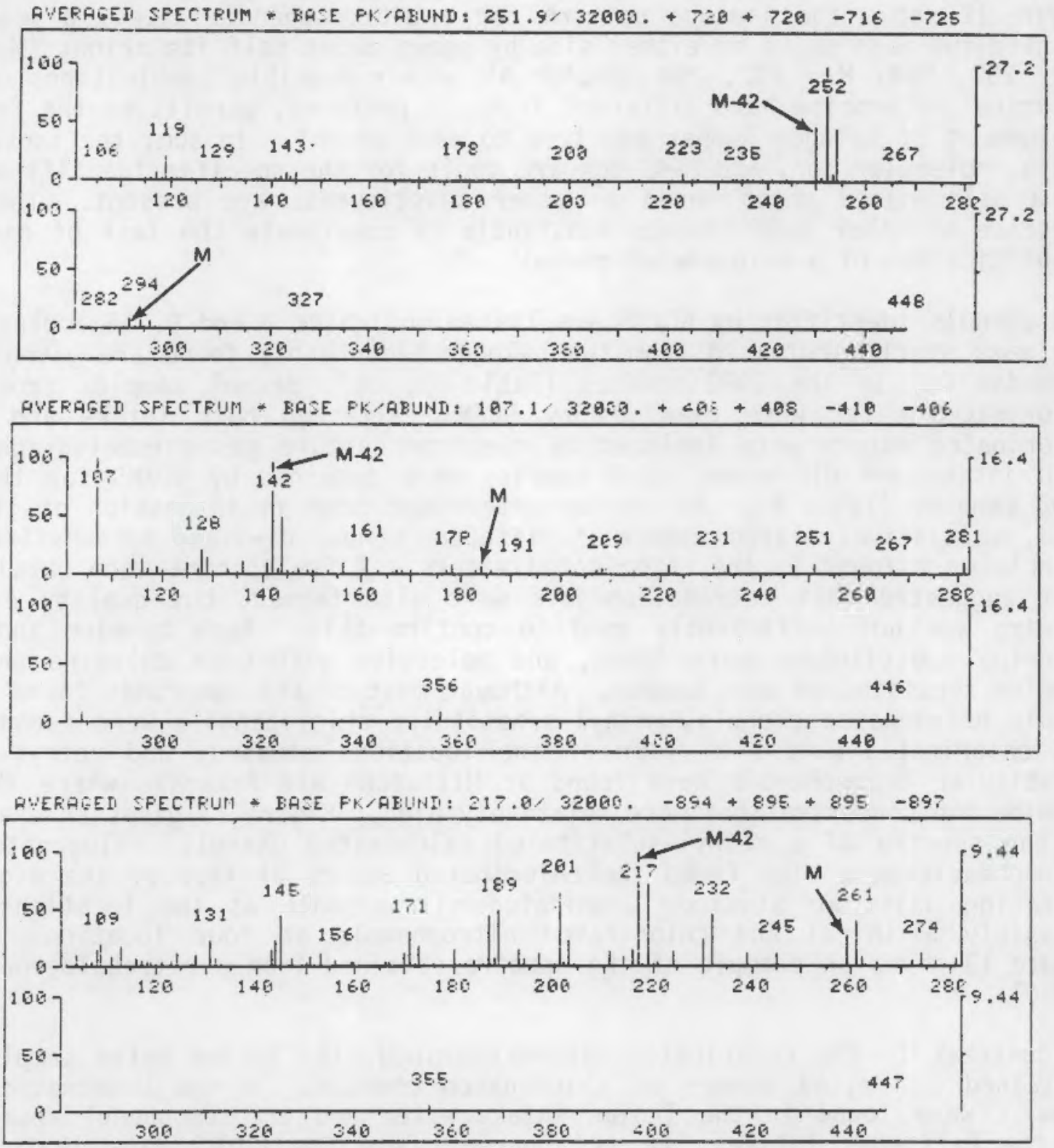

FIGURE 12. Spectra of Phenols Found in Power Plant Tower Water Samples. Top: Dibromophenol Acetate (Trojan), Middle: Chloromethylphenol Acetate (Trojan), Bottom: Bromonitrophenol Acetate (Palisades) 
TABLE 8. Halogenated Phenols Determined to be Present in XAD-2 Extracts of Chlorinated Power Plant Discharges Using GC/MS (1980 Sampling)

\begin{tabular}{|c|c|c|c|c|c|c|c|}
\hline$\#^{(a)}$ & Phenol & Mass & $\operatorname{RRT}^{(b)}$ & $\begin{array}{l}\text { Duane } \\
\text { Arnold }\end{array}$ & Millstone & $\begin{array}{l}\text { Arkansas } \\
\text { Unit } \# 1\end{array}$ & $\begin{array}{c}\text { Arkansas } \\
\text { Unit \#2 (TWR) }\end{array}$ \\
\hline 1 & Monochloro & 128 & $\begin{array}{l}0.688 \\
0.734\end{array}$ & $x$ & $\begin{array}{l}x \\
x\end{array}$ & $\begin{array}{l}x \\
x\end{array}$ & $x$ \\
\hline 2 & Chloromethyl & 142 & 0.830 & $x$ & & $x$ & $x$ \\
\hline 3 & Monobromo & 172 & $\begin{array}{l}0.789 \\
0.844\end{array}$ & & $\stackrel{?}{x}^{(c)}$ & $\dot{?}$ & $\begin{array}{l}x \\
x\end{array}$ \\
\hline 4 & Dichloro & 162 & $\begin{array}{l}0.877 \\
0.848\end{array}$ & $\begin{array}{l}x \\
x\end{array}$ & $x$ & $\begin{array}{l}x \\
x\end{array}$ & $\begin{array}{l}x \\
x\end{array}$ \\
\hline 5 & Bromomethyl & 186 & $\begin{array}{l}0.934 \\
0.952\end{array}$ & & $\begin{array}{l}x \\
x\end{array}$ & $x$ & $x$ \\
\hline 6 & Bromochloro & 206 & $\begin{array}{l}0.980 \\
0.989 \\
0.991\end{array}$ & $x$ & $?$ & $\begin{array}{l}x \\
x \\
?\end{array}$ & $\begin{array}{l}x \\
x\end{array}$ \\
\hline 7 & Trichloro & 196 & 1.000 & $x$ & & $x$ & $x$ \\
\hline 8 & Dibromo & 250 & $\begin{array}{l}1.051 \\
1.088\end{array}$ & $x$ & $x$ & $\begin{array}{l}x \\
x\end{array}$ & $\begin{array}{l}x \\
x\end{array}$ \\
\hline 9 & Bromodichloro & 240 & $\begin{array}{l}1.098 \\
1.108\end{array}$ & & $\begin{array}{l}x \\
x\end{array}$ & $\begin{array}{l}x \\
x\end{array}$ & $\begin{array}{l}x \\
x\end{array}$ \\
\hline 10 & Bromodimethy? & 200 & 1.112 & & $x$ & & 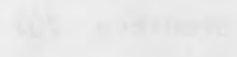 \\
\hline 11 & Bromonitro & 217 & $\begin{array}{l}1.140 \\
1.162\end{array}$ & & & & $\begin{array}{l}x \\
x\end{array}$ \\
\hline 12 & Dibromomethy 1 & 264 & 1.185 & & $x$ & & $x$ \\
\hline 13 & Dibromochioro & 284 & $\begin{array}{l}1.195 \\
1.203\end{array}$ & ? & & $\begin{array}{l}x \\
x\end{array}$ & $\begin{array}{l}x \\
x\end{array}$ \\
\hline 14 & $\begin{array}{l}\text { Bromodichloro } \\
\text { methyl }\end{array}$ & 254 & $\begin{array}{l}1.254 \\
1.261\end{array}$ & & & & $\begin{array}{l}x \\
x\end{array}$ \\
\hline 15 & Tribromo & 328 & 1.297 & $x$ & $x$ & $x$ & $x$ \\
\hline 16 & Dibromonitro $^{(d)}$ & 295 & 1.357 & $?$ & & & $?$ \\
\hline 17 & Tribromomethy1 & 342 & 1.452 & & & & $x$ \\
\hline
\end{tabular}

(a) Number corresponds to chromatographic peaks identified at Arkansas Unit \#2 in Figure 15 (b) Retention time relative to trichlorophenol

(c) ? = molecular $i$ on and retention time consistent with identity, spectra quality too poor to permit definite assignment

(d) Spectra quality too poor to positively identify as a nitrophenol 
TABLE 9. Halogenated Phenols Determined to be Present in XAD-2 Extracts of Power Plant Waters Using GM/MS Analysis (1982 Sampling)

\begin{tabular}{|c|c|c|c|c|c|c|c|c|c|c|}
\hline \multirow[b]{2}{*}{ Phenol } & \multirow[b]{2}{*}{ Mass } & \multirow[b]{2}{*}{$\mathrm{RRT}^{\text {(a) }}$} & \multicolumn{2}{|c|}{ Edwin Hatch } & \multicolumn{2}{|c|}{ Beaver Valley } & \multicolumn{2}{|c|}{ Trojan } & \multicolumn{2}{|c|}{ Palisades } \\
\hline & & & Intake & Discharge & Intake & Discharge & Intake & Tower & Intake & Tomer \\
\hline Monochloro & 128 & $\begin{array}{l}0.688 \\
0.734\end{array}$ & & $\begin{array}{l}x \\
x\end{array}$ & $x$ & $\begin{array}{l}x \\
x\end{array}$ & $x$ & $\begin{array}{l}x \\
x\end{array}$ & $x$ & $x$ \\
\hline Chloromethyl & 142 & $\begin{array}{l}0.786 \\
0.830 \\
0.838 \\
0.870\end{array}$ & & $\begin{array}{l}x \\
x\end{array}$ & & & & $\begin{array}{l}x \\
x\end{array}$ & & \\
\hline Monobromo & 172 & $\begin{array}{l}0.789 \\
0.844\end{array}$ & & $\begin{array}{l}x \\
x\end{array}$ & & $\begin{array}{l}x \\
x\end{array}$ & & $\begin{array}{l}x \\
x\end{array}$ & & $\begin{array}{l}x \\
x\end{array}$ \\
\hline Dichloro & 162 & $\begin{array}{l}0.848 \\
0.877\end{array}$ & $\begin{array}{l}x \\
x\end{array}$ & $\begin{array}{l}x \\
x\end{array}$ & $\begin{array}{l}x \\
x\end{array}$ & $\begin{array}{l}x \\
x\end{array}$ & $x$ & $\begin{array}{l}x \\
x\end{array}$ & $x$ & $\begin{array}{l}x \\
x\end{array}$ \\
\hline Bromochloro & 206 & $\begin{array}{l}0.980 \\
0.989 \\
0.991\end{array}$ & & $\begin{array}{l}x \\
x \\
x\end{array}$ & & $\begin{array}{l}x \\
x \\
x\end{array}$ & & $\begin{array}{l}x \\
x\end{array}$ & & $\begin{array}{l}x \\
x \\
x\end{array}$ \\
\hline Trichloro & 196 & 1.000 & $x$ & $x$ & $x$ & $x$ & & $x$ & $x$ & $x$ \\
\hline Chloronitro & 173 & $\begin{array}{l}1.038 \\
1.056\end{array}$ & & $\begin{array}{l}x \\
x\end{array}$ & & $\begin{array}{l}x \\
x\end{array}$ & & $\begin{array}{l}x \\
x\end{array}$ & & $\begin{array}{l}x \\
x\end{array}$ \\
\hline Dibromo & 250 & $\begin{array}{l}1.051 \\
1.088\end{array}$ & & $?^{(b)}$ & & $\begin{array}{l}x \\
x\end{array}$ & & $\begin{array}{l}x \\
x\end{array}$ & & $\begin{array}{l}x \\
x\end{array}$ \\
\hline Bromodichloro & 240 & $\begin{array}{l}1.098 \\
1.108\end{array}$ & & $\begin{array}{l}x \\
x\end{array}$ & & $\begin{array}{l}x \\
x\end{array}$ & $x$ & $\begin{array}{l}x \\
x\end{array}$ & & $\begin{array}{l}x \\
x\end{array}$ \\
\hline Dichloromethyl & 190 & 1.112 & & $x$ & & & & $x$ & & $x$ \\
\hline Dichloronitro & 207 & 1.142 & & $x$ & & & & $x$ & & \\
\hline Bromonitro & 217 & $\begin{array}{l}1.140 \\
1.162\end{array}$ & & & & & & & & $\begin{array}{l}x \\
x\end{array}$ \\
\hline Dibromochloro & 284 & $\begin{array}{l}1.195 \\
1.203\end{array}$ & & $\begin{array}{l}x \\
x\end{array}$ & & $\begin{array}{l}x \\
x\end{array}$ & & $\begin{array}{l}x \\
x\end{array}$ & & \\
\hline Tribromo & 328 & 1.297 & & & & $x$ & $x$ & $x$ & $x$ & $x$ \\
\hline$u^{(c)}-$ Nitrochlor & & 203 & & 1.290 & & & & & & $x$ \\
\hline U-Monobromo & 230 & $\begin{array}{l}1.279 \\
1.281\end{array}$ & & & & & = & $\begin{array}{l}x \\
x\end{array}$ & & \\
\hline U-Bromonitro & 247 & 1.367 & & & $x$ & $x$ & & $x$ & & \\
\hline U-Bromodichloro & & $\begin{array}{l}264 \\
1.400\end{array}$ & & 1.377 & & & $\begin{array}{l}x \\
x\end{array}$ & $x^{x}$ & $x$ & $x$ \\
\hline U-Trichloro & 256 & 1.381 & & $x$ & & & & & & \\
\hline
\end{tabular}

\footnotetext{
(a) Retention time relative to trichlorophenol

(b) ? = Molecular ion and retention time consistent with identity, spectra quality too poor to permit definite assignment

(c) Unidentified
} 

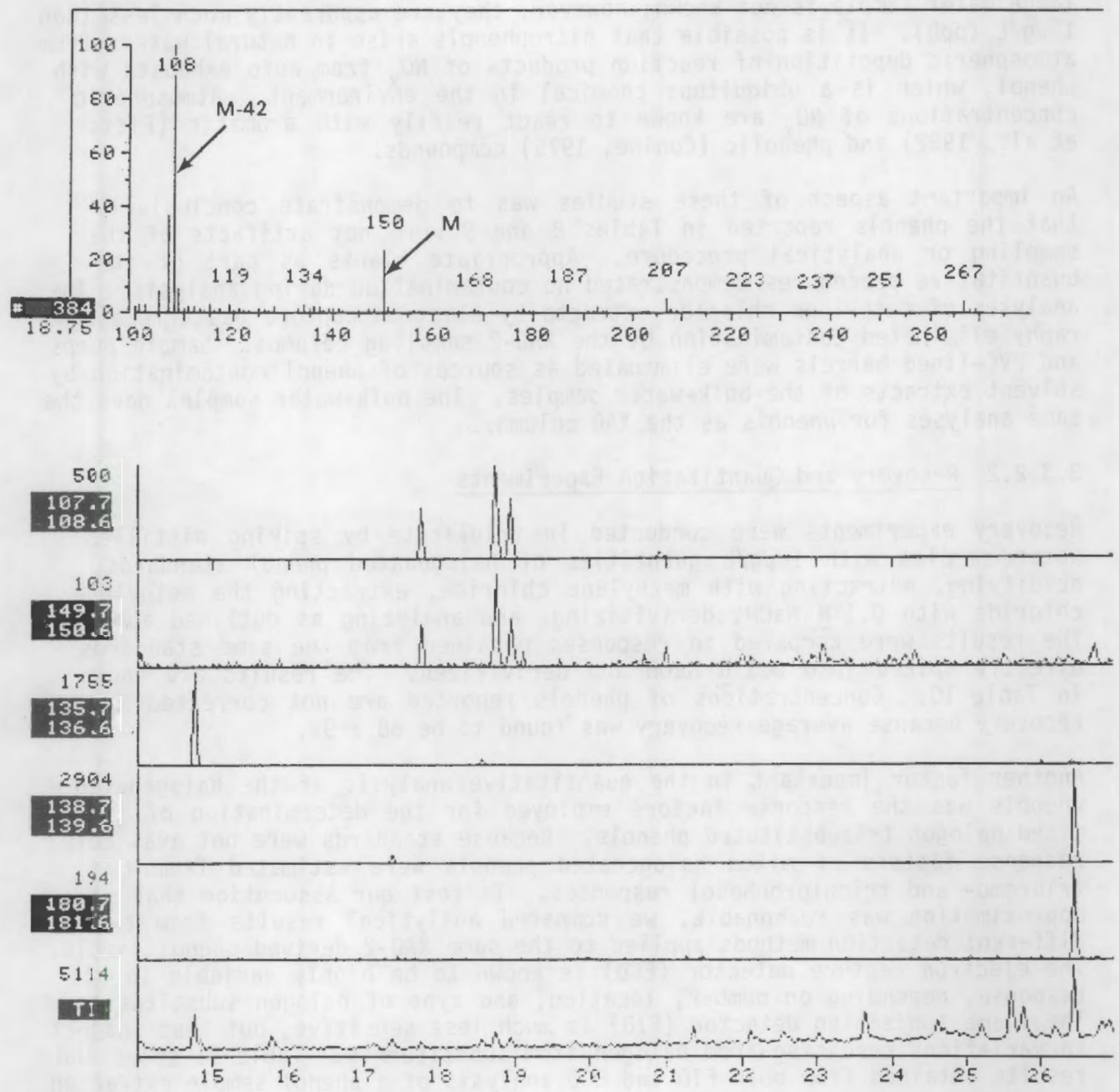

FIGURE 13. Phenols Found in Beaver Valley Discharge Samples. Top: Spectrum of Methylphenol Acetate, Bottom: Single Ion Scans of M-42 and M for Methylphenol Acetates $(108,150)$, M for Phenolacetate (136) and M-42 and M for Nitrophenol Acetate $(139,181)$. 
of these phenol species; nitrophenol was also found in XAD extracts of all waters examined, although in some samples concentrations were not high enough to yield a complete spectrum. Concentrations of nitrophenols found cannot be accurately reported because their adsorption efficiency from the large water sample is not known; however, they are apparently much less than $1 \mu \mathrm{g} / \mathrm{L}(\mathrm{ppb})$. It is possible that nitrophenols arise in natural waters from atmospheric deposition of reaction products of $\mathrm{NO}$ from auto exhausts with phenol, which is a ubiquitous chemical in the exivironment. Atmospheric concentrations of $\mathrm{NO}$ are known to react readily with aromatic (Pitts et al., 1982) and phenolic (Conine, 1975) compounds.

An important aspect of these studies was to demonstrate conclusively that the phenols reported in Tables 8 and 9 were not artifacts of the sampling or analytical procedure. Appropriate blanks as part of the quantitative procedures demonstrated no contamination during analysis. The analyses of methylene chloride extracts by electron capture gas chromatography eliminated contamination by the XAD-2 sampling columns. Sample pumps and PVC-lined barrels were eliminated as sources of phenol contamination by solvent extracts of the bulk-water samples. The bulk-water samples gave the same analyses for phenols as the XAD columns.

\subsubsection{Recovery and Quantitation Experiments}

Recovery experiments were conducted in triplicate by spiking distilled water samples with $1 \mu \mathrm{g} / \mathrm{L}$ quantities of halogenated phenol standards, acidifying, extracting with methylene chloride, extracting the methylene chloride with $0.1 \mathrm{~N} \mathrm{NaOH}$, derivitizing, and analyzing as outlined above. The results were compared to responses obtained from the same standards directly spiked into $0.1 \mathrm{~N} \mathrm{NaOH}$ and derivitized. The results are shown in Table 10. Concentrations of phenols reported are not corrected for recovery because average recovery was found to be $88 \pm 9 \%$.

Another factor important in the quantitative analysis of the halogenated phenols was the response factors employed for the determination of the mixed halogen trisubstituted phenols. Because standards were not available, response factors of mixed halogenated phenols were estimated from the tribromo- and trichlorophenol responses. To test our assumption that this approximation was reasonable, we compared analytical results from two different detection methods applied to the same XAD-2 derived phenol sample. The electron capture detector (ECD) is known to be highly variable in its response, depending on number, location, and type of halogen substituents. The flame ionization detector (FID) is much less sensitive, but less subject to variations resulting from halogen atom substituents. Table 11 shows the results obtained from both FID and ECD analysis of a phenol sample extracted by XAD-2 column adsorption from the Arkansas Unit \#2 cooling tower basin. In both experiments, tribromophenol was used as the analytical standard. The sample had to be concentrated to about $200 \mu \mathrm{L}$ to permit a quantifiable FID response, which detracts from the accuracy of the comparison; however, the experiment shows sufficiently good agreement between the analyses to give confidence in the concentrations reported for the ECD analysis of the mixed trihalogenated phenols. 
TABLE 10. Recovery of Halogenated Phenols From Two-Liter Spiked Water Samples

\begin{tabular}{lcr}
\hline \multicolumn{1}{c}{ Phenol } & $\begin{array}{c}\text { Concentration } \\
(\mu \mathrm{g} / \mathrm{L})\end{array}$ & $\begin{array}{c}\text { Recovery } \pm \text { SD } \\
(\mathrm{n}=3)\end{array}$ \\
\hline 2,6-Dichloro & 1.28 & $87.0 \pm 3.3$ \\
3,5-Dichloro & 1.64 & $77.7 \pm 1.4$ \\
2-Bromo-4-methyl & 1.26 & $99.5 \pm 8.5$ \\
2,4,6-Trichloro & 1.42 & $90.8 \pm 3.3$ \\
3,4,5-Trichloro & 1.74 & $88.6 \pm 5.7$ \\
2,4,5-Trichloro & 1.66 & $90.6 \pm 4.4$ \\
2,3,4-Trichloro & 2.28 & $89.6 \pm 2.4$ \\
2,6-Dibromo-4-methyl & 1.77 & $94.0 \pm 1.4$ \\
p-Bromo & 1.48 & $62.5 \pm 4.2$ \\
2,5-Dichloro & 2.08 & $87.2 \pm 1.3$ \\
2,3-Dichloro & 1.68 & $96.2 \pm 2.9$ \\
3,4-Dichloro & 2.44 & $74.6 \pm 2.0$ \\
2,3,6-Trichloro & 1.78 & $93.0 \pm 0.6$ \\
2,4-Dibromo & 1.32 & $92.5 \pm 0.9$ \\
2,3,5-Trichloro & 1.97 & $94.0 \pm 1.2$ \\
2,6-Dibromo & 1.30 & $92.1 \pm 1.4$ \\
2,4,6-Tribromo & 1.30 & $91.2 \pm 1.5$ \\
& & Average Recovery $88.3 \pm 9.0 \%$ \\
\hline
\end{tabular}

TABLE 11. Comparison of Electron Capture Analys is With Flame Ionization Analysis (Concentrations are $\mu \mathrm{g} / \mathrm{L}$ water)

\begin{tabular}{lll}
\hline \multicolumn{1}{c}{ Phenol } & ECD & FID \\
\hline Bromodichloro 1 & 0.03 & 0.03 \\
Bromodichloro 2 & 0.04 & 0.07 \\
Dibromochloro 1 & 0.07 & 0.04 \\
Dibromochloro 2 & 0.12 & 0.13 \\
2,4,6-Tribromo & 0.23 & 0.17 \\
\hline
\end{tabular}


The efficiency of recovery of phenols on the XAD-2 columns was determined by comparing the quantities of phenols trapped on both top and bottom XAD-2 columns with the phenols recovered using the methylene chloride extraction procedure. The data presented in Table 12 show that the recovery of halogenated phenols on the XAD-2 columns is surprisingly high considering that about $200 \mathrm{~L}$ of water were extracted. About $88 \%$ of the phenols trapped by the $X A D-2$ columns were on the upper column.

\subsubsection{Concentrations of Halogenated Phenols in Power Plant Waters}

The concentrations of phenols determined in the power plant cooling waters at the seven power stations studied are given in Tables 13 and 14. Figure 14 shows chromatograms obtained from the Trojan plant samples that illustrate the results obtained from the methylene chloride extracts. All of the chromatograms were obtained at the same sample concentration and instrument settings, and show the large differences in phenol concentrations observed among the cooling tower sample, diluted discharge sample, and the cooling water intake sample. The several peaks marked "B" in Figure 14 were found to originate in the methylene chloride solvent used for extraction in the field. Fortunately, they did not interfere with the analyses.

The data for Tables 13 and 14 reflect differences in sampling. For the samplings in $1980,2-\mathrm{L}$ samples of water were extracted with methylene chloride for each of two fillings of the sample barrel (the barrel was filled more than once to provide enough water for 200-L XAD samples). Thus, the 1980 data (Table 13) report the mean and standard error obtained from these two samplings, conducted about $24 \mathrm{hr}$ apart. For the

TABLE 12. Phenol Recovery From Arkansas Unit \#2 Tower on XAD-2 Res in

\begin{tabular}{ccccc}
\hline \multicolumn{1}{c}{ Phenol } & $\begin{array}{c}\text { Top } \\
\text { XAD-2 }\end{array}$ & $\begin{array}{c}\text { Bottom } \\
\text { XAD-2 }\end{array}$ & $\begin{array}{c}\text { Total } \\
\text { on XAD-2 }\end{array}$ & $\begin{array}{c}\text { Methylene Chloride } \\
\text { Extract }( \pm S E, n=2)\end{array}$ \\
\hline 2,4,6-Trichloro & 0.01 & $\operatorname{tr}$ & 0.01 & $0.01 \pm 0.01$ \\
Bromodichloro 1 & 0.03 & $\operatorname{tr}$ & 0.03 & $0.05 \pm 0.01$ \\
Bromodichloro 2 & 0.04 & 0.01 & 0.05 & $0.03 \pm 0.01$ \\
Dibromochloro 1 & 0.07 & 0.01 & 0.08 & $0.10 \pm 0.02$ \\
Dibromochloro 2 & 0.12 & 0.02 & 0.14 & $0.20 \pm 0.05$ \\
2,4,6-Tribromo & 0.23 & 0.03 & 0.26 & $0.36 \pm 0.10$ \\
& & & 0.57 & 0.75 \\
\hline
\end{tabular}

\&Recovered by top column: 67\%

\&Recovered by both columns: $76 \%$ 
TABLE 13. Analysis of Halogenated Phenols in Methylene Chloride Extracts of Two-Liter Water Samples From Millstone, Arnold, and Arkansas Power Plants (Concentrations in $\mu \mathrm{g} / \mathrm{L}$ of water)

\begin{tabular}{|c|c|c|c|c|c|c|c|}
\hline \multirow[b]{2}{*}{ Phenol } & \multicolumn{2}{|c|}{ Duane Arnold } & \multicolumn{2}{|c|}{ Millstone } & \multicolumn{3}{|c|}{ Arkansas } \\
\hline & Intake & Discharge & Intake & Discharge & Intake & Unit & Tower \\
\hline $\begin{array}{l}\text { 2-Bromo-4-chloro } \\
\text { 4-Bromo-2-chloro }\end{array}$ & $\begin{array}{l}\text { nd (a) } \\
\text { nd }\end{array}$ & $d^{d(b)}$ & $\begin{array}{l}\text { nd } \\
\text { nd }\end{array}$ & $\begin{array}{l}\text { nd } \\
\text { nd }\end{array}$ & $\begin{array}{l}\text { nd } \\
\text { nd }\end{array}$ & $\begin{array}{l}\text { nd } \\
\text { nd }\end{array}$ & $\begin{array}{l}d \\
d\end{array}$ \\
\hline 2,4,6-Trichloro & tr & $0.68 \pm .08$ & nd & d & nd & nd & $0.01 \pm .00$ \\
\hline $\begin{array}{l}2,4 \text {-Dibromo } \\
2,6 \text {-Dibromo }\end{array}$ & $\begin{array}{l}\text { nd } \\
\text { nd }\end{array}$ & $\begin{array}{c}0.04 \pm .02 \\
\text { nd }\end{array}$ & $\begin{array}{l}\text { nd } \\
\text { nd }\end{array}$ & $\begin{array}{l}\mathrm{tr} \\
\mathrm{tr}\end{array}$ & $\begin{array}{l}\text { (c) } \\
\text { nd }\end{array}$ & (c) & $\begin{array}{c}\text { (c) } \\
0.01 \pm .00\end{array}$ \\
\hline $\begin{array}{l}\text { Bromodichloro } \\
\text { Bromodichloro } \\
\text { Bromodimethyl }\end{array}$ & $\begin{array}{l}\text { nd } \\
\text { nd } \\
\text { nd }\end{array}$ & $\begin{array}{c}0.38 \pm .01 \\
0.15 \pm .02 \\
\text { nd }\end{array}$ & $\begin{array}{l}\text { nd } \\
\text { nd } \\
\text { nd }\end{array}$ & $\frac{d}{d} 0.02 \pm .02$ & $\begin{array}{l}\text { nd } \\
\text { nd } \\
\text { nd }\end{array}$ & $\begin{array}{l}\text { nd } \\
\text { nd } \\
\text { nd }\end{array}$ & $\begin{array}{c}0.05 \pm .01 \\
0.03 \pm .01 \\
\text { nd }\end{array}$ \\
\hline $\begin{array}{l}\text { Bromonitro } \\
\text { Bromonitro } \\
2,4-\text { Dibromo-dimethyl }\end{array}$ & $\begin{array}{l}\text { nd } \\
\text { nd } \\
\text { nd }\end{array}$ & $\begin{array}{l}\text { nd } \\
\text { nd } \\
\text { nd }\end{array}$ & $\begin{array}{l}\text { nd } \\
\text { nd } \\
\text { nd }\end{array}$ & $\begin{array}{l}\text { nd } \\
\text { nd } \\
0.03 \pm .00\end{array}$ & $\begin{array}{l}\text { nd } \\
\text { nd } \\
\text { nd }\end{array}$ & $\begin{array}{l}\text { nd } \\
\text { nd } \\
\text { nd }\end{array}$ & $\begin{array}{l}0.11 \pm .04 \\
0.03 \pm .02 \\
0.01 \pm .00\end{array}$ \\
\hline $\begin{array}{l}\text { Dibromochloro } \\
\text { Dibromochloro } \\
\text { Bromodichloromethyl } \\
\text { Bromodichloromethyl }\end{array}$ & $\begin{array}{l}\text { nd } \\
\text { nd } \\
\text { nd } \\
\text { nd }\end{array}$ & $\begin{array}{l}0.05 \pm .05 \\
\text { nd } \\
\text { nd } \\
\text { nd }\end{array}$ & $\begin{array}{l}\text { nd } \\
\text { nd } \\
\text { nd } \\
\text { nd }\end{array}$ & $\begin{array}{l}0.02 \pm .02 \\
\text { nd } \\
\text { d } \\
\text { nd }\end{array}$ & $\begin{array}{l}\text { nd } \\
\text { nd } \\
\text { nd } \\
\text { nd }\end{array}$ & $\begin{array}{l}\text { nd } \\
\text { nd } \\
\text { nd } \\
\text { nd }\end{array}$ & $\begin{array}{l}0.10 \pm .02 \\
0.20 \pm .05 \\
0.01 \pm .00 \\
0.01 \pm .00\end{array}$ \\
\hline $\begin{array}{l}\text { 2,4,6-Tribromo } \\
\text { Dibromonitro(?) } \\
\text { Tribromomethy1 }\end{array}$ & $\begin{array}{l}\text { nd } \\
\text { nd } \\
\text { nd }\end{array}$ & $\begin{array}{l}0.04 \pm .02 \\
\text { nd } \\
0.01 \pm .01\end{array}$ & $\begin{array}{l}0.01 \pm .00 \\
\text { nd } \\
\text { nd }\end{array}$ & $\begin{array}{l}0.36 \pm .01 \\
\text { nd } \\
0.01 \pm .01\end{array}$ & $\begin{array}{l}\text { tr } \\
\text { nd } \\
\text { nd }\end{array}$ & $\begin{array}{l}\text { tr } \\
\text { nd } \\
\text { nd }\end{array}$ & $\begin{array}{l}0.36 \pm .10 \\
0.04 \pm .01 \\
0.08 \pm .01\end{array}$ \\
\hline Total Phenols & $\operatorname{tr}$ & 1.35 & 0.01 & 0.44 & $\operatorname{tr}$ & $\operatorname{tr}$ & 1.05 \\
\hline
\end{tabular}

(a) nd $=$ not detected

(b) $d$ = detected at the 0.01 level in only one duplicate

(c) Interference from solvent component

1982 data, sample barrels were only filled once, and triplicate 1-L samples were obtained. All replicates for the 1982 samples were analyzed, and the means are reported in Table 14 without accompanying standard deviations, which ranged from $10 \%$ to $30 \%$. The variability for these samples was higher than that reported for the recovery studies (Table 10) because of the necessity to evaporate the samples to $200 \mu 1$ for analysis at the $0.01 \mu \mathrm{g} / \mathrm{L}$ level. Recoveries exceeded $90 \%$.

In general, the results obtained from the methylene chloride extracts confirm the qualitative information obtained from the GC/MS studies (Tables 8 and 9) that the chlorinated waters contain a much larger variety of halogenated phenols than the intake waters. The data in Tables 13 and 14 also demonstrate that the halogenated pheno? concentrations are significantly larger in the chlorinated waters than in intake waters. The largest concentrations of halogenated phenols found was in the Trojan tower basin $(4.25 \mu \mathrm{g} / \mathrm{L})$. The highest phenol concentration discharged directly to the receiving water was from Duane Arnold $(1.35 \mu \mathrm{g} / \mathrm{L})$, followed by Beaver. Valley $(0.67 \mu \mathrm{g} / \mathrm{L})$. Both these plants discharge blowdown without substantial dilution. Based on 
TABLE 14. Analysis of Halogenated Phenols in Methylene Chloride Extracts of 1-Liter Water Samples From Hatch, Beaver Valley, Trojan and Palisades (Concentrations in $\mu \mathrm{g} / \mathrm{L}$ of water)

\begin{tabular}{|c|c|c|c|c|c|c|c|c|c|c|c|c|}
\hline \multirow{2}{*}{ * (a) } & \multirow[b]{2}{*}{ Phenol } & \multicolumn{2}{|c|}{ Hatch } & \multicolumn{3}{|c|}{ Beaver Valley } & \multicolumn{3}{|c|}{ Trojan } & \multicolumn{3}{|c|}{ Palisades } \\
\hline & & Tntake & Disch. & Tntake & Tower & Disch. & Tntake & Tower & Disch. & Tntake & Tower & Disch. \\
\hline $\begin{array}{l}1 \\
2 \\
3 \\
4 \\
5\end{array}$ & $\begin{array}{l}2,6 \text {-Dichloro } \\
2,5 \text { or } 3,5 \text {-Dichloro } \\
\text { Bromochloro } \\
\text { 2-Bromo-4-chloro } \\
\text { 4-Bromo-2-chloro }\end{array}$ & $\begin{array}{l}\text { nd } \\
\text { nd } \\
\text { nd } \\
\text { nd } \\
\text { nd }\end{array}$ & $\begin{array}{l}\text { tr } \\
0.01 \\
\text { nd } \\
\text { nd } \\
\text { nd }\end{array}$ & $\begin{array}{l}\text { nd (b) } \\
0.01 \\
\text { nd } \\
\text { nd } \\
\text { nd }\end{array}$ & $\begin{array}{l}\text { nd } \\
0.02 \\
0.02 \\
0.01 \\
0.01\end{array}$ & $\begin{array}{l}d^{(c)} \\
0.02 \\
0.01 \\
0.01 \\
t r\end{array}$ & $\begin{array}{l}\text { nd } \\
\text { tr } \\
\text { nd } \\
\text { nd } \\
\text { nd }\end{array}$ & $\begin{array}{l}0.13 \\
0.05 \\
0.10 \\
0.03 \\
0.02\end{array}$ & $\begin{array}{l}0.01 \\
0.01 \\
\text { tr } \\
\text { nd } \\
\text { nd }\end{array}$ & $\begin{array}{l}\text { nd } \\
\text { nd } \\
\text { nd } \\
\text { nd } \\
\text { nd }\end{array}$ & $\begin{array}{l}\text { nd } \\
\operatorname{nd}(d) \\
t r \\
d\end{array}$ & $\begin{array}{l}\text { d } \\
\text { nd } \\
\text { nd } \\
\text { tr } \\
\text { nd }\end{array}$ \\
\hline $\begin{array}{r}7 \\
8 \\
9 \\
10 \\
11\end{array}$ & $\begin{array}{l}\text { 2,6-Dibromo } \\
2,4 \text {-Dibromo } \\
\text { Bromodichloro } \\
\text { Bromodichloro } \\
\text { Dichlorodimethyl }\end{array}$ & $\begin{array}{l}\text { nd } \\
\text { nd } \\
\text { nd } \\
\text { nd } \\
\text { nd }\end{array}$ & $\begin{array}{l}\text { nd } \\
\text { nd } \\
\text { nd } \\
\text { nd } \\
0.02\end{array}$ & $\begin{array}{l}\text { nd } \\
\text { d } \\
0.01 \\
\text { nd } \\
\text { nd }\end{array}$ & $\begin{array}{l}0.05 \\
0.02 \\
0.03 \\
0.02 \\
d\end{array}$ & $\begin{array}{l}0.03 \\
0.02 \\
0.06 \\
0.05 \\
\text { tr }\end{array}$ & $\begin{array}{l}\text { nd } \\
\text { nd } \\
\text { nd } \\
\text { nd } \\
\text { nd }\end{array}$ & $\begin{array}{l}0.04 \\
0.01 \\
1.12 \\
0.46 \\
0.27\end{array}$ & $\begin{array}{c}\text { nd } \\
\text { nd } \\
0.13 \\
0.06 \\
0.02\end{array}$ & $\begin{array}{l}\text { nd } \\
\text { nd } \\
\text { nd } \\
\text { d } \\
\text { nd }\end{array}$ & $\begin{array}{c}0.01 \\
\operatorname{tr} \\
0.03 \\
0.01 \\
0.03\end{array}$ & $\begin{array}{c}d \\
\text { nd } \\
0.02 \\
0.01 \\
0.05\end{array}$ \\
\hline $\begin{array}{l}12 \\
13 \\
14 \\
15\end{array}$ & $\begin{array}{l}\text { Dibromochloro } \\
\text { Dibromochloro } \\
\text { Bromo }(M=230) \\
\text { Chloronitro }(M=203)\end{array}$ & $\begin{array}{l}\text { nd } \\
\text { nd } \\
\text { nd } \\
\text { nd }\end{array}$ & $\begin{array}{l}\text { nd } \\
\text { nd } \\
\text { nd } \\
\text { nd }\end{array}$ & $\begin{array}{l}\operatorname{tr} \\
\text { tr } \\
\text { nd } \\
d\end{array}$ & $\begin{array}{l}0.04 \\
0.05 \\
d \\
0.06\end{array}$ & $\begin{array}{l}0.06 \\
0.07 \\
\text { nd } \\
0.09\end{array}$ & $\begin{array}{l}\text { tr } \\
0.05 \\
t r\end{array}$ & $\begin{array}{l}0.25 \\
0.34 \\
0.15 \\
0.22\end{array}$ & $\begin{array}{l}0.03 \\
0.04 \\
0.09 \\
0.02\end{array}$ & $\begin{array}{l}\text { nd } \\
\text { nd } \\
\text { nd } \\
\text { nd }\end{array}$ & $\begin{array}{l}0.03 \\
0.02 \\
\text { nd } \\
0.04\end{array}$ & $\begin{array}{l}0.01 \\
0.01 \\
\text { nd } \\
0.02\end{array}$ \\
\hline 16 & $2,4,6$-Tribromo & nd & nd & nd & 0.06 & 0.11 & nd & 0.08 & 0.01 & nd & 0.04 & $\operatorname{tr}$ \\
\hline $\begin{array}{l}17 \\
18 \\
19\end{array}$ & $\begin{array}{l}\text { Bromonitro }(M=247) \\
\text { Dichlorobromo }(M=264) \\
\text { Dichlorobromo }(M=264)\end{array}$ & $\begin{array}{l}\text { nd } \\
0.01 \\
\text { nd }\end{array}$ & $\begin{array}{l}\text { nd } \\
0.06 \\
\text { nd }\end{array}$ & $\begin{array}{l}\text { nd } \\
0.01 \\
\text { nd }\end{array}$ & $\begin{array}{l}0.02 \\
0.01 \\
0.01\end{array}$ & $\begin{array}{l}0.03 \\
0.04 \\
0.04\end{array}$ & $\begin{array}{l}\text { nd } \\
0.01 \\
0.02\end{array}$ & $\begin{array}{c}0.07 \\
d \\
\text { nd }\end{array}$ & $\begin{array}{l}\text { nd } \\
\text { tr } \\
\text { nd }\end{array}$ & $\begin{array}{l}\text { nd } \\
\text { tr } \\
\text { nd }\end{array}$ & $\begin{array}{l}\text { nd } \\
\text { nd } \\
\text { nd }\end{array}$ & $\begin{array}{l}\text { nd } \\
\text { nd } \\
\text { nd }\end{array}$ \\
\hline Total & Phenols & - & 0.09 & 0.03 & 0.51 & 0.67 & 0.09 & 4.25 & 0.56 & - & 0.25 & 0.14 \\
\hline
\end{tabular}

\footnotetext{
(a) Number refers to chromatographic peak number shown in Fig. 14.

(b) nd $=$ not detected in any of the replicates

(c) $d=$ detected in concentration $<n n 1 \mathrm{lla} / \mathrm{L}$ in some, but not all replicate samples

(d) $\mathrm{tr}=$ detected in concentrations $<0.01 \mu \mathrm{g} / \mathrm{L}$ in all replicates

(e) Duplicate determinations
} 


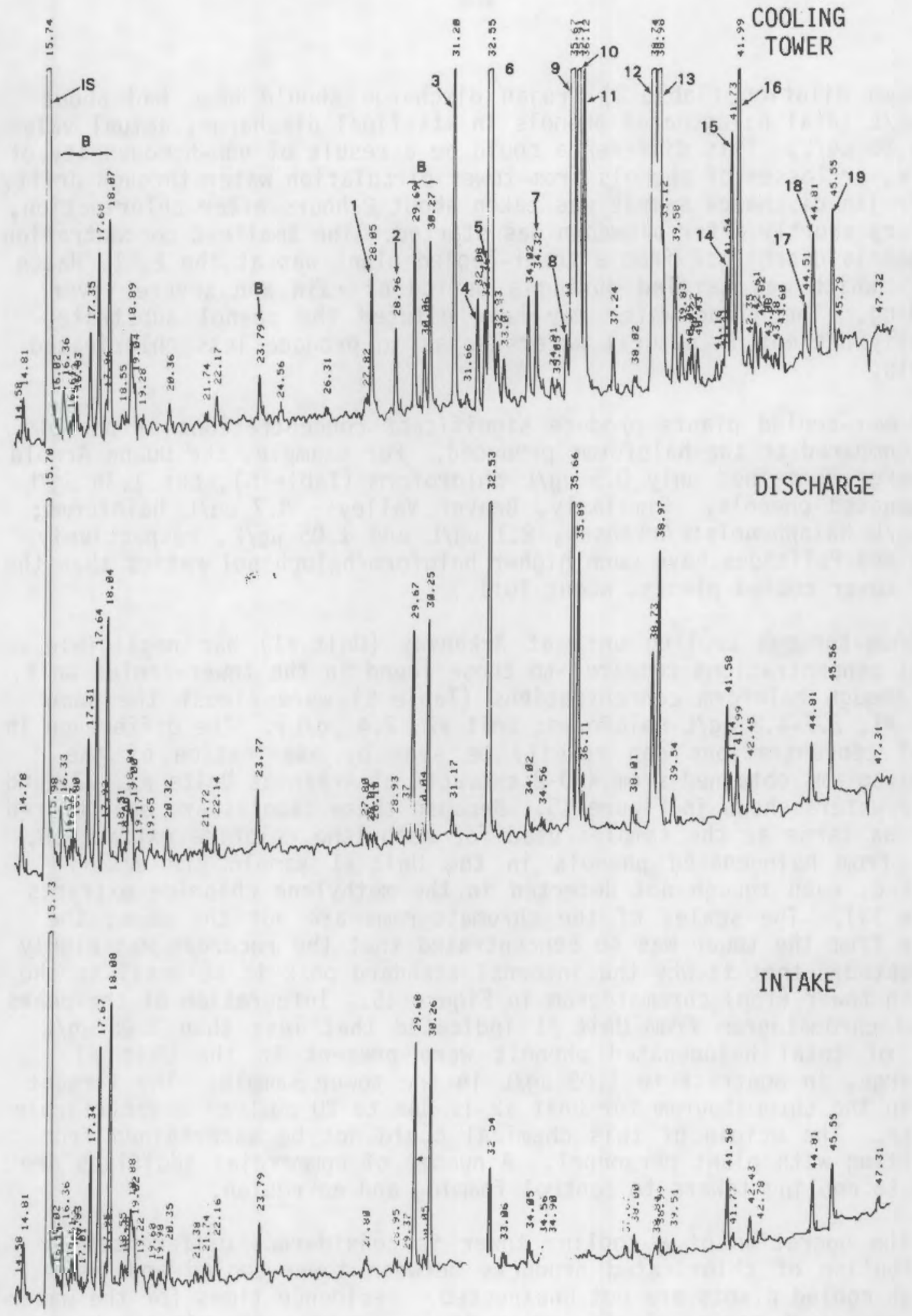

FIGURE 14. Electron Capture Capillary Chromatograms of AcetateDerivitized Phenols Found in Trojan Water Samples. Numbers Refer to Compounds Listed in Table 14. "B" refers to Peaks Found in Blank. IS is the Internal Standard, Dichlorobenzene. 
blowdown dilution (Table 2) Trojan discharge should have had about $1.5 \mathrm{\mu g} / \mathrm{L}$ total halogenated phenols in its final discharge; actual value was $0.56 \mu \mathrm{g} / \mathrm{L}$. This difference could be a result of non-homogeneity of sample, or losses of phenols from tower circulation water through drift. The Trojan discharge sample was taken about 2 hours after chlorination, but very shortly after blowdown was started. The smallest concentration of phenols discharged from a tower-cooled plant was at the E. I. Hatch plant, which was sampled during a period of rain and severe river flooding. The flood water may have diluted the phenol substrate normally present in natural waters so as to produce less chlorinated phenols.

The tower-cooled plants produce significant concentrations of phenols when compared to the haloforms produced. For example, the Duane Arnold discharge contained only $0.5 \mu \mathrm{g} / \mathrm{L}$ chloroform (Table 6), but $1.35 \mu \mathrm{g} / \mathrm{L}$. halogenated phenols. Similarly, Beaver Valley: $0.7 \mu \mathrm{g} / \mathrm{L}$ haloforms; $0.7 \mu \mathrm{g} / \mathrm{L}$ halophenols; Arkansas, $2.1 \mu \mathrm{g} / \mathrm{L}$ and $1.05 \mu \mathrm{g} / \mathrm{L}$, respectively. Hatch and $\mathrm{Pal}$ isades have much higher haloform/halophenol ratios than the other tower cooled plants, about 10:1.

The once-through cooling unit at Arkansas (Unit \#1) had negligible phenol concentrations compared to those found in the tower-cooled unit, even though haloform concentrations (Table 6) were almost the same (Unit \#1, 2.7-4.8 $\mu \mathrm{g} / \mathrm{L}$ haloforms; Unit \#2, 2.4 $\mu \mathrm{g} / \mathrm{L}$ ). The difference in phenol concentrations can readily be seen by examination of the chromatograms obtained from XAD-2 extracts of Arkansas Units \#1, \#2, and intake waters shown in Figure 15. Because these samples are one hundred times as large as the samples used for methylene chloride extraction, peaks from halogenated phenols in the Unit \#1 sample are easily detected, even though not detected in the methylene chloride extracts (Table 13). The scales of the chromatograms are not the same; the sample from the tower was so concentrated that the recorder was highly attenuated: that is why the internal standard peak is so small in the cooling tower (top) chromatogram in Figure 15. Integration of the peaks in the chromatogram from Unit \#1 indicated that less than $0.05 \mu \mathrm{g} / \mathrm{L}$ (ppb) of total halogenated phenols were present in the Unit \#1 discharge, in contrast to $1.05 \mu \mathrm{g} / \mathrm{L}$ in the tower sample. The largest peak in the chromatogram for Unit \#2 is due to $20 \mu \mathrm{g} / \mathrm{L}$ of benzotriazole acetate. The origin of this chemical could not be ascertained from consulting with plant personnel. A number of commercial additives are added to cooling towers to control foaming and corrosion.

When the operation of a cooling tower is considered, differences in distribution of chlorinated products between tower-cooled and oncethrough cooled plants are not unexpected. Residence times for the water in once-through cooled plants are on the order of a few minutes before being discharged into receiving waters, but for cooling tower plants, water residence times are measured in hours since the same water is used over and over again for cooling. In addition, cooling tower water is substantially evaporated during the cooling cycle, so that substrates 


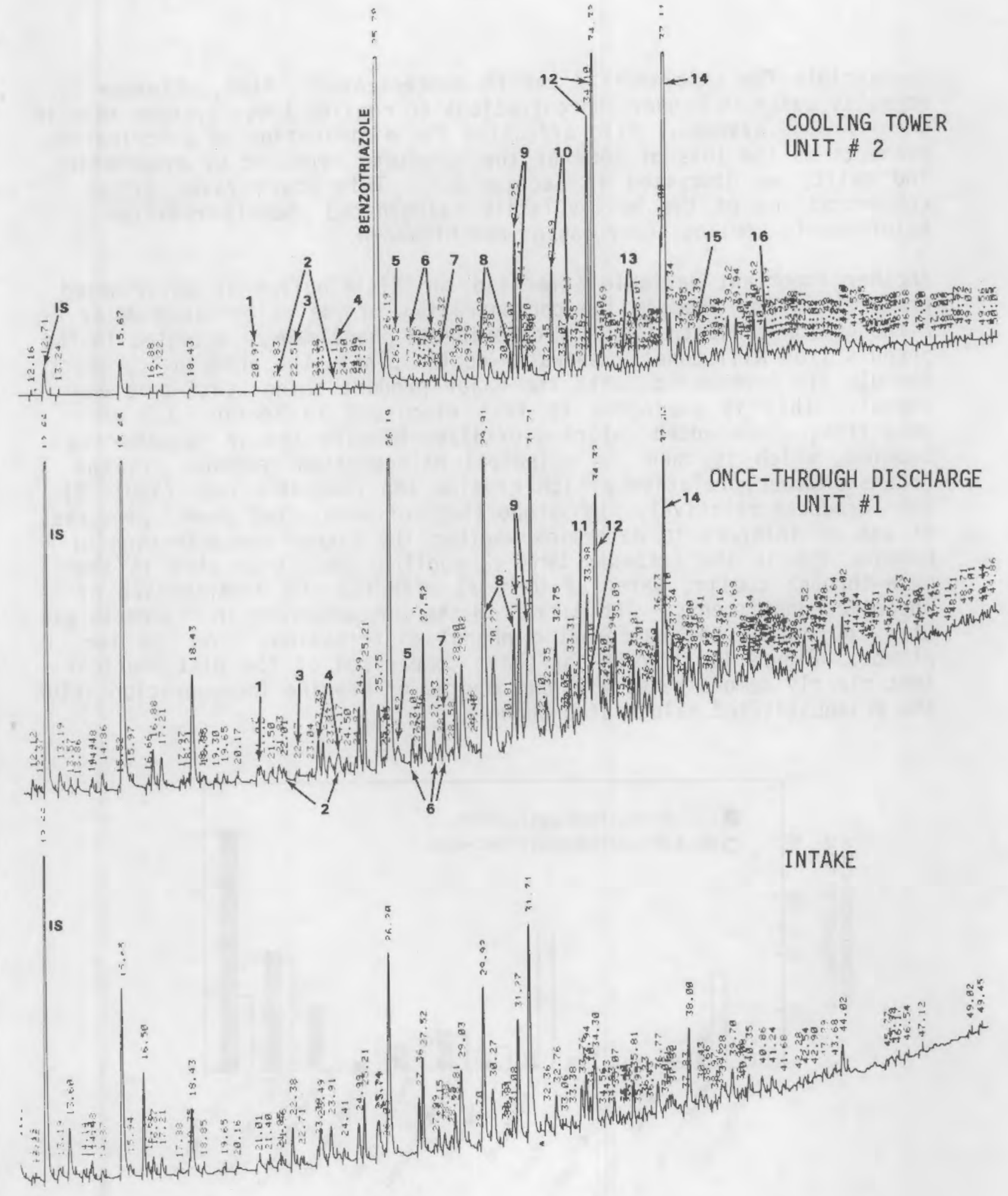

FIGURE 15. Electron Capture Capillary Chromatograms of Acetate-Derived Phenols Found in Arkansas Water Samples. Numbers Correspond to Compounds Listed in Table 8. Size of Internal Standard Peak (15) Indicates Extent of Recorder Attenuation. 
susceptible for chlorination can be concentrated. Also, chlorine is normally added in higher concentrations to cooling tower systems than in once-through systems. Also affecting the distribution of chlorination products is the loss of some of the haloforms produced by evaporation and drift, as discussed in Section 3.2. This would favor higher concentrations of the less volatile halogenated phenols relative to haloforms in cooling tower basins and blowdown.

Another important variable affecting the distribution of chlorinated products is the bromide ion concentration in the chlorinated water. Although low concentrations of chlorinated phenols were detected in the phenols from Millstone, a seawater-cooled plant, the principal product phenols are brominated, with the major product being 2,4,6-tribromophenol. This is analogous to that discussed in Section 3.2 on volatiles, where added chlorine oxidizes bromide ion in seawater to bromine, which is then the principal halogenation reagent. In the Arkansas tower, relatively high bromide ion concentrations (Table 3 ) also produced relatively high proportions of brominated phenol products. It was of interest to determine whether the higher concentration of bromide ion in the Arkansas Unit \#2 cooling tower over that in the once-through cooling water of Unit \#1 affected the distribution of phenolic constituents. The data from the chromatograms in Figure 15 was used to compute the halogenated phenol distributions from the two plants. Figure 16 shows a bar-chart comparison of the distributions that clearly demonstrates a higher degree of bromine incorporation into the trisubstituted halogenated phenols.

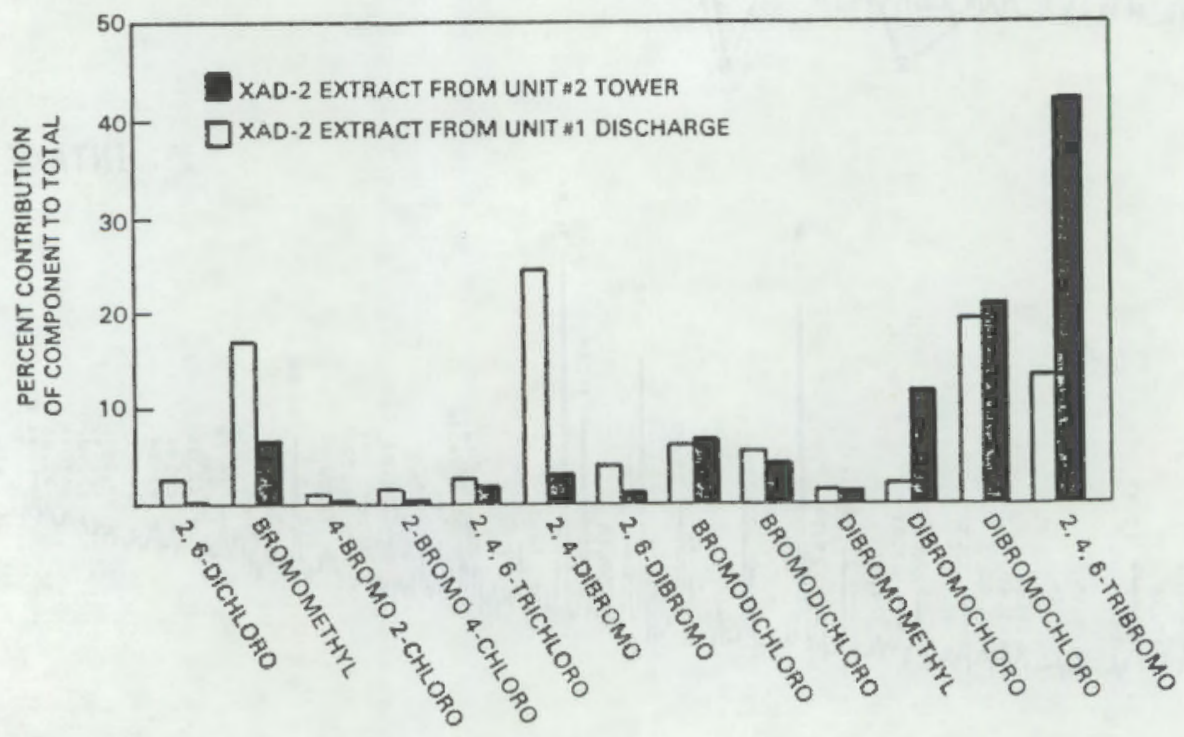

FIGURE 16. Comparison of Halogenated Phenol Distributions From Arkansas Tower and Once-Through Discharge. Total Phenols in Unit \#1 Discharge Were $0.05 \mu \mathrm{g} / \mathrm{L}$. 
Brominated phenol products were found in all but one power plant cooling system (Hatch) even though the concentrations of bromide ion were often very low compared to the concentration of added chlorine. A significant enhancement of the rate of haloform production has been noted when bromide ion is present (Minear and Bird, 1980; 01iver, 1980). It is apparent that this rate of enhancement also applies to halogenated phenol formation in cooling waters.

\subsection{Base-Neutral Organohalogen Material and Total Organic Halogen}

The methods developed for use in these studies (Bean et al., 1980) incorporated the total organic halogen (TOX) concept developed by Glaze et al., (1977) for the characterization of chlorination products for drinking and waste waters. This method involved adsorption of organohalogens from a water sample onto XAD-2 columns, and determining the quantity of halogen adsorbed by microcoulometric analys is of ether extracts of the XAD-2 columns. The haloforms present in the ether extract are analyzed by gas chromatography so that the organic halogen present in the water can be reported as "haloform halogen" and "nonhaloform halogen."

Although we adhered to this methodology for analysis of XAD-2 extracts of power plant waters, our findings that halogenated phenols can contribute significantly to the organic material adsorbed on XAD-2 resin have prompted us to address three categories of organohalogen in chlorinated water; haloform halogen, halophenol halogen, and baseneutral halogen.

\subsubsection{Methods}

Most of the methods for extraction, separation, and analysis of XAD-2 column extracts have been previously documented (Bean et al., 1980), therfore, the methods used for TOX and base-neutral analyses will not be elaborated in detail. The overall scheme is shown in Figure 17. After drying, the ether extract (Mallinckrodt) was subsampled so that the haloforms could be determined by gas chromatography and the total organohalogen determined by microcoulometry. A Dohrmann/Envirotech Microcoulometric Titration System was used for the Tox analysis. After subsampling, the ether sample was extracted with sodium hydroxide to remove phenols, dried again, the volume determined by weighing, and then evaporated using a Snyder column to $2 \mathrm{~mL}$ of $n$-heptane. The heptane concentrate, which contains the base-neutral fraction, was analyzed for organic halogen by microcoulometry. It is then evaporated to $200 \mu \mathrm{L}$ for examination by GC/MS, using the same column and conditions described for phenol acetates in Section 3.3.

Heptane concentrates from three plants were separated on $7 \mathrm{~g}$ of $10 \%$ water deactivated silica gel (100-200 mesh), following the method described in Bean et al. (1980). Chromatographic fractions were obtained by eluting successively with $20 \mathrm{ml}$ portions of n-hexane, $20 \%$ ethyl ether in hexane, and $100 \%$ ethyl ether. All ether used for the chromatography was $25 \%$ water saturated. 


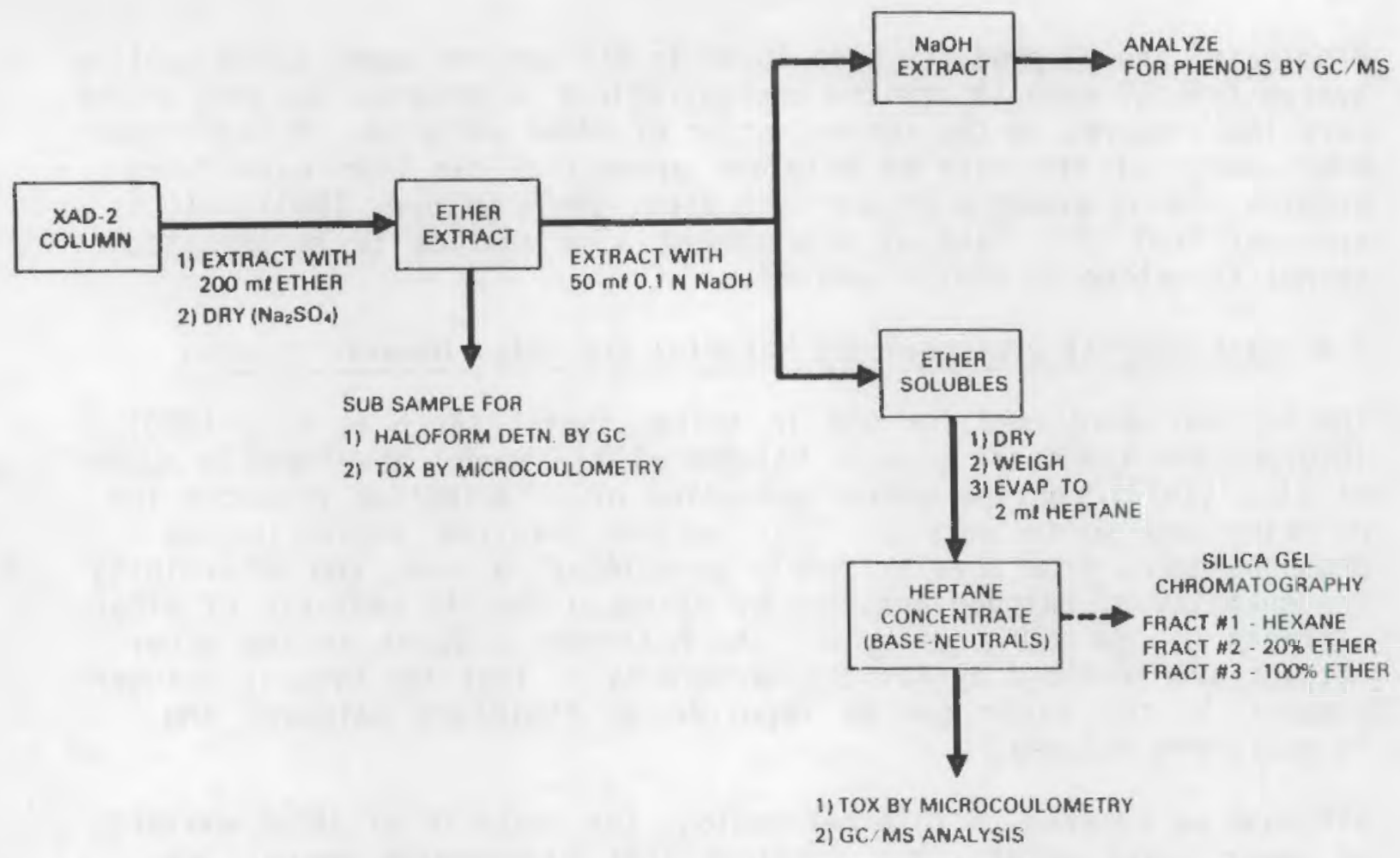

FIGURE 17. Scheme for Analys is of XAD-2 Extracts for Organic Halogen

\subsubsection{Results}

The measurements obtained from the XAD-2 samples from the seven power stations are presented in Table 15 (A through $G$ ). To obtain the data, top and bottom XAD-2 columns (see Figure 1 for XAD column sampling arrangement) were analyzed separately in order to obtain an estimate of the extraction efficiency of the XAD columns. The results from both top and bottom were added together to obtain a total value for the water sample. When both "A" and "B" column sets were analyzed (Figure 1), the results are shown in Table 15 as an average + the standard error (range). Only one set of top and bottom columñs were analyzed for the Beaver Valley, Trojan, and Palisades facilities. Although duplicate top columns were analyzed for the Arkansas site, only one bottom column was analyzed as a check on column efficiency; thus, the average results are reported on the basis of top column only. For Duane Arnold and Millstone, ether extracts of bottom columns were analyzed for haloforms and TOX, but the corresponding heptane concentrates were not obtained.

Although analytical reproduciblity for the haloform determinations in Table 15 were well within $5 \%$, reproducibility of the microcoulometer is highly variable (Bean et al., 1980). The type of variability reported in Table 15 for the microcoulometric TOX measurements was determined largely by the demands of the individual sample. If the instrument 
TABLE 15A. Analysis of XAD-2 Samples for Total Organic Halogen and Haloforms - Duane Arnold

(Concentrations expressed as micrograms per liter of water)

\begin{tabular}{|c|c|c|c|c|c|c|c|c|}
\hline \multirow{2}{*}{ Samp 1} & & \multicolumn{4}{|c|}{ Haloforms in Ether Extract } & \multirow[b]{2}{*}{$\begin{array}{l}\text { TOCl as } \\
\text { Hal of orm }\end{array}$} & \multirow[b]{2}{*}{$\begin{array}{l}\text { TOCl in } \\
\text { Ether Extract }\end{array}$} & \multirow[b]{2}{*}{$\begin{array}{l}\text { TOCl in } \\
\text { Heptane Conc. }\end{array}$} \\
\hline & & $\mathrm{CHCl}_{3}$ & $\mathrm{CHBrCl}_{2}$ & $\mathrm{CHBr}_{2} \mathrm{Cl}$ & $\mathrm{CHBr}_{3}$ & & & \\
\hline \multirow[t]{2}{*}{ Intake A } & $\begin{array}{l}\text { Top } \\
\text { Bottom }\end{array}$ & $\begin{array}{c}0.17 \\
\operatorname{tr}\end{array}$ & - & - & - & 0.16 & $\begin{array}{c}0.99 \pm 0.37 \\
-\end{array}$ & $\begin{array}{l}0.98 \pm 0.05 \\
\text { not determined }\end{array}$ \\
\hline & Total A & 0.17 & - & - & - & 0.16 & 0.99 & \\
\hline \multirow[t]{2}{*}{ Intake B } & $\begin{array}{l}\text { Top } \\
\text { Bottom }\end{array}$ & $\begin{array}{c}0.02 \\
\operatorname{tr}\end{array}$ & - & - & - & 0.02 & $\begin{array}{c}0.99 \pm 0.22 \\
-\end{array}$ & $\begin{array}{l}0.61 \pm 0.07 \\
\text { not determined }\end{array}$ \\
\hline & Total B & 0.02 & - & - & - & 0.02 & 0.99 & \\
\hline \multicolumn{2}{|c|}{ Average Intake \pm S.E. } & $\underline{0.10 \pm 0.07}$ & $=$ & $=$ & $=$ & $\underline{0.09 \pm 0.07}$ & $\underline{0.99 \pm 0.00}$ & 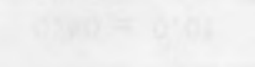 \\
\hline \multirow[t]{2}{*}{ Discharge $A$} & $\begin{array}{l}\text { Top } \\
\text { Bottom }\end{array}$ & $\begin{array}{l}0.41 \\
0.11\end{array}$ & $\begin{array}{l}\text { tr } \\
\text { tr }\end{array}$ & - & - & $\begin{array}{l}0.37 \\
0.10\end{array}$ & $\begin{array}{l}2.25 \pm 0.32 \\
0.24 \pm 0.07\end{array}$ & $\begin{array}{l}1.74 \pm 0.06 \\
\text { not determined }\end{array}$ \\
\hline & Total A & 0.52 & $\operatorname{tr}$ & - & - & 0.47 & 2.49 & \\
\hline \multirow[t]{2}{*}{ Discharge $B$} & $\begin{array}{l}\text { Top } \\
\text { Bottom }\end{array}$ & $\begin{array}{l}0.14 \\
0.09\end{array}$ & $\begin{array}{c}0.01 \\
t . r\end{array}$ & - & - & $\begin{array}{l}0.13 \\
0.08\end{array}$ & $\begin{array}{l}1.23 \pm 0.21 \\
0.14 \pm 0.03\end{array}$ & $\begin{array}{l}2.66 \pm 0.10 \\
\text { not determined }\end{array}$ \\
\hline & Total B & 0.23 & $\operatorname{tr}$ & - & - & 0.21 & 1.37 & \\
\hline \multicolumn{2}{|c|}{ Average Discharge \pm S.E. } & $0.37 \pm 0.14$ & $\underline{\mathrm{tr}}$ & $=$ & $=$ & $0.34 \pm 0.11$ & $1.93 \pm 0.56$ & \\
\hline
\end{tabular}


TABLE 15B. Analysis of XAD-2 Samples for Total Organic Halogen and Haloforms - Millstone

(Concentrations expressed as micrograms per liter of water)

\begin{tabular}{|c|c|c|c|c|c|c|c|c|}
\hline \multirow{2}{*}{\multicolumn{2}{|c|}{ Sample }} & \multicolumn{4}{|c|}{ Hai of orms in Ether Extract } & \multirow[b]{2}{*}{$\begin{array}{l}\text { TOCl as } \\
\text { Haloform }\end{array}$} & \multirow[b]{2}{*}{$\begin{array}{l}\text { TOC1 in } \\
\text { Ether Extract }\end{array}$} & \multirow[b]{2}{*}{$\begin{array}{l}\text { TOCl in } \\
\text { Heptane Conc. }\end{array}$} \\
\hline & & $\mathrm{CHCl}_{3}$ & $\mathrm{CHBrCl}_{2}$ & $\mathrm{CHBr}_{2} \mathrm{Cl}$ & $\mathrm{CHBr}_{3}$ & & & \\
\hline \multirow[t]{3}{*}{ Intake A } & Top & 0.01 & $\operatorname{tr}$ & - & 0.25 & 0.18 & $0.42 \div 0.04$ & \multirow{3}{*}{$\begin{array}{l}0.30 \pm 0.01 \\
\text { not determined }\end{array}$} \\
\hline & Bottom & - & - & - & - & - & $0.39 \pm 0.22$ & \\
\hline & Total A & 0.01 & - & - & 0.25 & 0.18 & 0.81 & \\
\hline \multirow[t]{3}{*}{ Intake B } & Top & - & 0.01 & 0.01 & 0.54 & 0.23 & $1.34 \pm 0.16$ & \multirow{3}{*}{$\begin{array}{l}0.40 \pm 0.01 \\
\text { not determined }\end{array}$} \\
\hline & Bottom & - & - & - & - & - & - & \\
\hline & Total B & - & 0.01 & 0.01 & 0.54 & 0.23 & 1.34 & \\
\hline Average Inta & \pm S.E. & $<\underline{00.01}$ & $<\underline{00.01}$ & $<00.01$ & $\underline{0.40 \pm 0.14}$ & $\underline{0.21 \pm 0.02}$ & $1.08 \pm 0.26$ & \\
\hline \multirow[t]{3}{*}{ Discharge $A$} & Top & 0.11 & 0.01 & 0.09 & 6.03 & 2.70 & $3.42 \pm 0.12$ & \multirow{3}{*}{$\begin{array}{l}2.43 \pm 0.06 \\
\text { not determined }\end{array}$} \\
\hline & Bottom & - & 0.01 & 0.07 & 0.69 & 0.32 & $2.38 \pm 0.89$ & \\
\hline & $\underline{\text { Total A }}$ & 0.11 & 0.02 & 0.16 & 6.72 & 3.02 & 5.80 & \\
\hline \multirow[t]{3}{*}{ Discharge $B$} & Top & $\operatorname{tr}$ & 0.01 & 0.16 & 6.64 & 2.90 & $4.47 \pm 0.17$ & \multirow{3}{*}{$\begin{array}{l}4.37 \pm 0.45 \\
\text { not determined }\end{array}$} \\
\hline & Bottom & - & 0.01 & 0.01 & 6.14 & 0.16 & $0.47 \pm 0.27$ & \\
\hline & Total B & $<0.1$ & 0.02 & 0.17 & 6.78 & 3.06 & 4.94 & \\
\hline \multicolumn{2}{|c|}{ Average Discharge \pm S.E. } & $\leq 0.1$ & $0.02 \pm 0$ & $0.17 \pm 0.01$ & $\underline{6.75 \pm 0.05}$ & $3.04 \pm 0.02$ & $5.37 \pm 0.43$ & \\
\hline
\end{tabular}


TABLE 15C. Analysis of XAD-2 Samples for Total Organic Halogen and Haloforms - Arkansas

(Concentrations expressed as micrograms per liter of water)

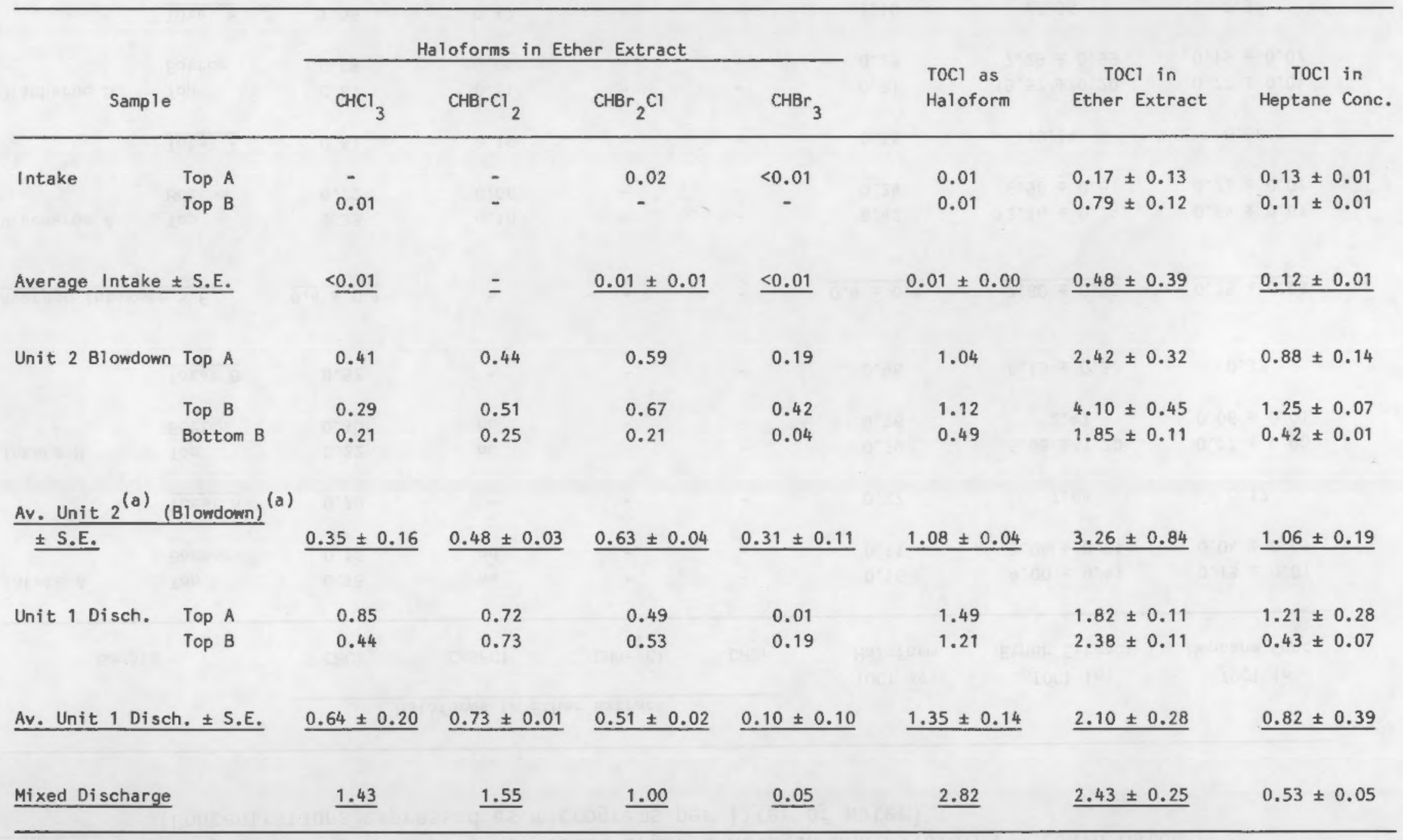

(a) Top only 
TABLE 15D. Analysis of XAD-2 Samples for Total Organic Halogen and Haloforms - Edwin Hatch

(Concentrations expressed as micrograms per liter of water)

\begin{tabular}{|c|c|c|c|c|c|c|c|c|}
\hline \multirow{2}{*}{\multicolumn{2}{|c|}{ Sample }} & \multicolumn{4}{|c|}{ Haloforms in Ether Extract } & \multirow[b]{2}{*}{$\begin{array}{l}\text { TOCl as } \\
\text { Haloform }\end{array}$} & \multirow[b]{2}{*}{$\begin{array}{l}\text { TOC1 in } \\
\text { Ether Extract }\end{array}$} & \multirow[b]{2}{*}{$\begin{array}{c}\text { TOC1 in } \\
\text { Heptane Conc. }\end{array}$} \\
\hline & & $\mathrm{CHCl}_{3}$ & $\mathrm{CHBrCl}_{2}$ & $\mathrm{CHBr}_{2} \mathrm{Cl}$ & $\mathrm{CHBr}_{3}$ & & & \\
\hline \multirow[t]{2}{*}{ Intake A } & Top & 0.18 & nd & - & - & 0.16 & $4.00 \pm 0.41$ & $0.13 \pm 0.01$ \\
\hline & Bottom & 0.12 & nd & - & - & 0.11 & $3.04 \pm 0.21$ & $0.04 \pm 0.01$ \\
\hline 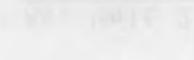 & Total A & 0.30 & - & - & - & 0.27 & 7.04 & 0.17 \\
\hline \multirow[t]{3}{*}{ Intake B } & Top & 0.22 & nd & - & - & 0.20 & $5.68 \pm 1.20$ & $0.27 \pm 0.00$ \\
\hline & Bottom & 0.30 & nd & - & - & 0.26 & 2.47 & $0.06 \pm 0.01$ \\
\hline & Total B & 0.52 & - & - & - & 0.46 & $8.15 \pm 0.52$ & 0.33 \\
\hline \multicolumn{2}{|c|}{ Average Intake $\pm S . E$. } & $0.4 \pm 0.1$ & - & - & - & $0.4 \pm 0.1$ & $7.60 \pm 0.55$ & $0.25 \pm 0.08$ \\
\hline \multirow[t]{3}{*}{ Discharge $A$} & Top & 0.39 & 0.10 & - & - & 0.42 & $12.16 \pm 0.74$ & $0.64 \pm 0.01$ \\
\hline & Bottom & 0.22 & 0.06 & - & - & 0.24 & $6.98 \pm 0.81$ & $0.22 \pm 0.01$ \\
\hline & Total A & 0.61 & 0.16 & - & - & 0.68 & 19.14 & 0.86 \\
\hline \multirow[t]{3}{*}{ Discharge $B$} & Top & 0.81 & 0.11 & - & - & 0.81 & $19.57 \pm 0.20$ & $0.72 \pm 0.04$ \\
\hline & Bottom & 0.28 & 0.06 & - & - & 0.29 & $7.29 \pm 0.99$ & $0.19 \pm 0.02$ \\
\hline & Total B & 1.09 & 0.17 & - & - & 1.10 & 26.86 & 0.91 \\
\hline \multicolumn{2}{|c|}{ Average Discharge $\pm 5 . E$. } & $\underline{0.85 \pm 0.24}$ & $0.17 \pm 0.01$ & - & - & $0.89 \pm 0.21$ & $23.00 \pm 3.86$ & $0.89 \pm 0.02$ \\
\hline
\end{tabular}


TABLE 15E. Analysis of XAD Samples for Total Organic Chlorine and Haloforms - Beaver Valley (Concentrations expressed as micrograms per liter of water)

\begin{tabular}{|c|c|c|c|c|c|c|c|c|}
\hline & \multirow{2}{*}{ Sample } & \multicolumn{4}{|c|}{ Haloforms in Ether Extract } & \multirow{2}{*}{$\begin{array}{l}\text { TOCl as } \\
\text { Hal oform }\end{array}$} & \multirow{2}{*}{$\begin{array}{l}\text { TOCl in } \\
\text { Ether Extract }\end{array}$} & \multirow{2}{*}{$\begin{array}{l}\text { TOCl in } \\
\text { Heptane Conc. }\end{array}$} \\
\hline & & $\mathrm{CHCl}_{3}$ & $\mathrm{CHBrCl}_{2}$ & $\mathrm{CHBr}_{2} \mathrm{Cl}$ & $\mathrm{CHBr}_{3}$ & & & \\
\hline \multicolumn{9}{|l|}{ Intake } \\
\hline & Top & 0.07 & 0.02 & 0.01 & nd & 0.09 & $10.9+0.6$ & $1.14 \pm 0.03$ \\
\hline & Bottom & 0.05 & 0.01 & $\operatorname{tr}$ & nd & 0.05 & $0.7 \pm 0.0$ & $0.32 \pm 0.01$ \\
\hline & Total & 0.12 & 0.03 & 0.01 & - & 0.14 & 11.6 & 1.46 \\
\hline \multicolumn{9}{|l|}{ Tower } \\
\hline & Top & 0.14 & 0.02 & 0.01 & 0.01 & 0.16 & $7.3 \pm 0.0$ & $0.71 \pm 0.01$ \\
\hline & Bottom & 0.10 & $\operatorname{tr}$ & nd & $\operatorname{tr}$ & 0.10 & $1.5 \pm 0.3$ & $0.45 \pm 0.01$ \\
\hline & Total & 0.24 & 0.02 & 0.01 & 0.01 & 0.26 & 8.8 & 1.16 \\
\hline \multicolumn{9}{|l|}{ Di scharge } \\
\hline & Top & 0.18 & 0.07 & 0.03 & 0.01 & 0.39 & $80.3 \pm 6.8$ & $1.66 \pm 0.01$ \\
\hline & Bottom & 0.09 & 0.03 & 0.01 & $\operatorname{tr}$ & 0.12 & $67.1 \pm 1.6$ & $0.31 \pm 0.00$ \\
\hline & Total & 0.27 & 0.10 & 0.04 & 0.01 & 0.51 & 147.4 & 1.97 \\
\hline
\end{tabular}


TABLE 15F. Analysis of XAD Samples for Total Organic Chlorine and Haloforms - Trojan (Concentrations expressed as micrograms per liter of Water)

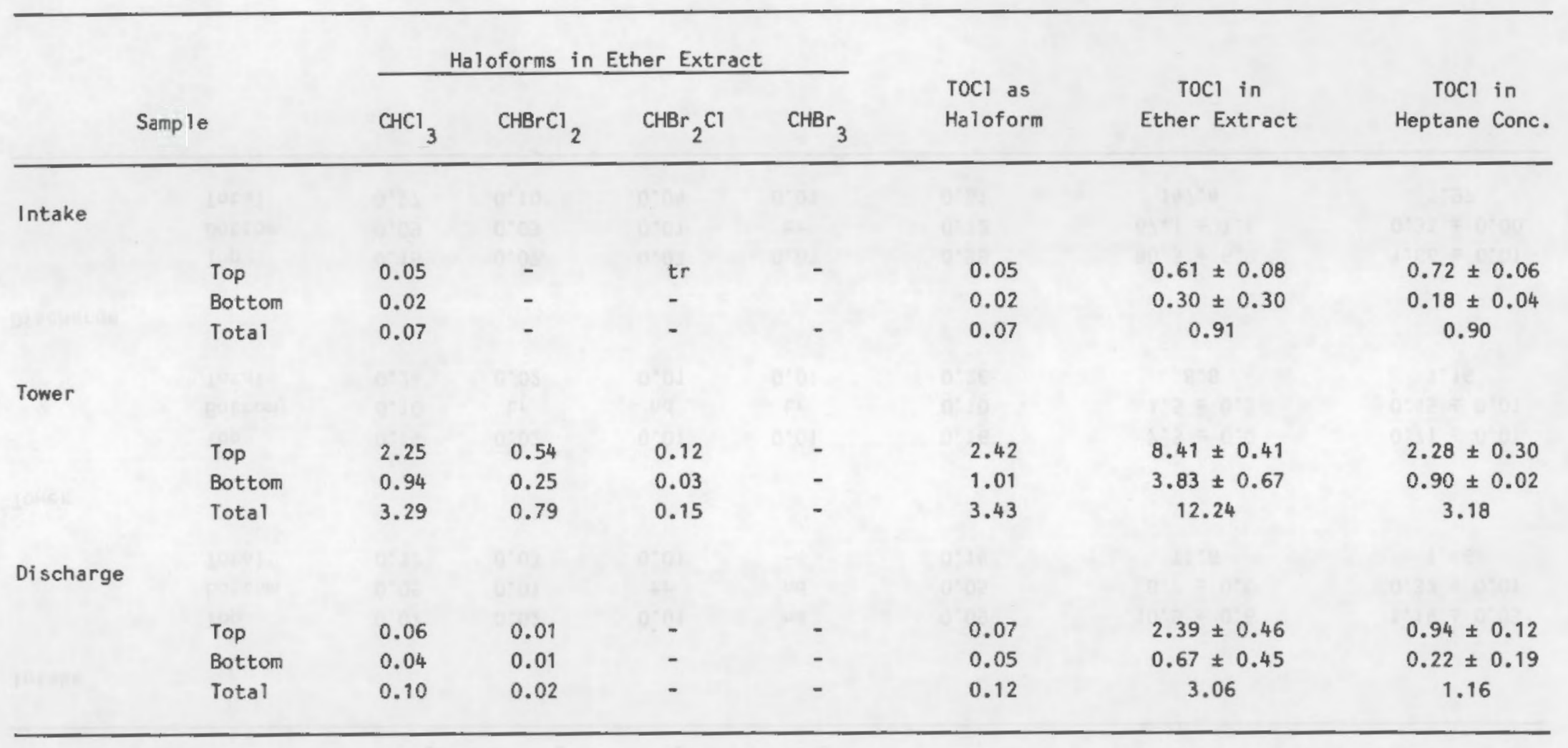


TABLE 15G. Analysis of XAD Samples for Total Organic Chlorine and Haloforms - Palisades (Concentrations Expressed as micrograms per liter of Water)

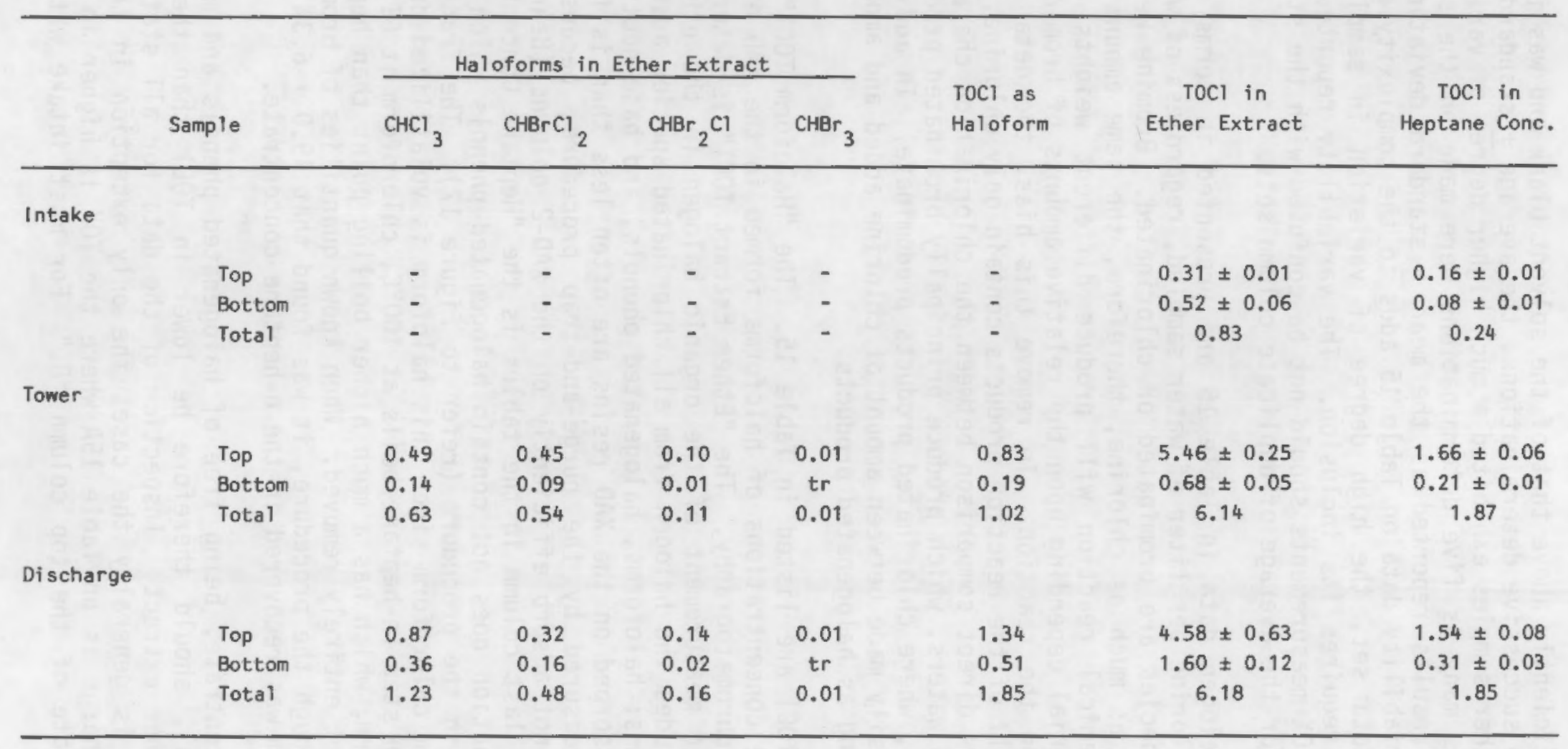


reading was sufficiently above that of the solvent blank and was in good agreement on two successive determinations, the average + standard error is reported. Other samples exhibited a much higher degree of variation; in that case, as many as five determinations were made on the same sample and the results reported as the mean + standard deviation. Although the variability data on Table 15 adds to the complexity of the already large data set, the high degree of variation in sample reproducibility requires its inclusion. The variability reported for the individual Tox measurements should not be confused with the standard error reported for the average of duplicate column sets.

A11 the organohalogen data in Table 15 are presented in terms of micrograms of chlorine per liter of water sampled, regardless of whether the principle species are brominated or chlorinated. Bromine weighs more than twice as much as chlorine, therefore, the same amount of chlorination chemical reaction will produce different weights of halogenated material depending upon the relative amounts of bromine and chlorine entering the reaction. To remove this bias, the data are reported as if all of the reaction products contain only chlorine. This convention allows direct comparison between the chlorination characteristics of marine waters, which produce principally brominated products, and fresh waters, where chlorinated products predominate. In addition, comparison is easily made between amount of chlorine added and amount of chlorine appearing as halogenated products.

Three types of TOCl are listed in Table 15. The "Haloform TOCl" is derived from the concentrations of haloforms formed in the XAD ether extracts by gas chromatography. The "Ether Extract TOC1" is determined by microulometric measurement of the organic halogen in the ether extract and includes the halogen from all chlorinated species adsorbed on the XAD columns; haloforms, halogenated phenols, and base-neutrals. The haloforms adsorbed on the XAD resins are often less than is found when directly measured by the purge-and-trap procedure, because chloroform does not adsorb efficiently on the XAD-2 columns (Bean et al., 1980). The last column in the tables is the "Heptane Concentrate TOC1." This fraction does not contain halogenated phenols which are removed earlier in the procedure (refer to Figure 17). The fraction also is free from chloroform since this haloform is volatilized during the concentration step (n-heptane boils at $100^{\circ} \mathrm{C}$, chloroform at $61.2^{\circ} \mathrm{C}$ ). However, bromoform, which has a much higher boiling point than heptane $\left(149.5{ }^{\circ} \mathrm{C}\right)$, is not entirely removed. When known quantities of bromoform were carried through the procedure, it was found that $49.0 \pm 6.3 \%(n=$ 3 ) of the broform was recovered in the $n$-heptane concentrate.

The heptane concentrate, being free of halogenated phenols and most haloform material, should therefore be lower in TOCl than the corresponding ether extract. Inspection of the data for all stations shows that this is generally the case; the only exception in the chlorinated discharge is on Table 15A where the ToX is higher in the heptane concentrate of the top column "B." For most intake water 
samples, there is fair agreement between values for ether extracts and heptane concentrates. This is to expected because concentrations of phenols and haloforms are low in the intake water and thus their removal has little effect on the TOCl level. The two intake samples, which show little agreement between ether extracts and heptane concentrates, are the Edwin Hatch and Beaver Valley plants. The measured TOCl was unusually high in the ether concentrates of all samples, and could not be accounted for. Analys is of a column used as a "trip blank" revealed an abnormally high TOCl measurement in the ether extract (equivalent to $6 \mu \mathrm{g} / \mathrm{L} \mathrm{TOCl}$ based on $100 \mathrm{~L}$ collected). This material was lost when the sample was evaporated into $n$-heptane, as the data on Tables 150 and $15 \mathrm{E}$ show. Contamination of the columns with methylene chloride during column preparation or transport is a possible explanation. In any event, the contamination of these sample columns did not allow for a valid analysis of the ether extractabie Tox.

The TOCl data on Table 15 is analyzed with respect to efficiency of extraction and reproducibility of duplicates in Table 16. The contaminated ether extracts from Hatch and Beaver Valley are not included in the analysis. The analyses for the ether extracts have been further subdivided into intake and discharge because TOCl concentrations were too low in most intake ether extracts to give accurate data; that is, the variability is due in large part to analytical error rather than column performance variability. The heptane samples were more concentrated, analytical accuracy was higher, therefore, both intake and discharge data are included together. The analys is in Table 16 shows that more than $75 \%$ of the organic chlorine found by analysis of top and bottom columns were found on the top columns, except in the case of ether extracts of intake samples. Agreement between duplicate column extracts was satisfactory, showing an average deviation

\section{TABLE 16. Characteristics of XAD Column Extraction Procedure}

A. Efficiency of Extraction of Organic Chlorine by XAD-2 Columns

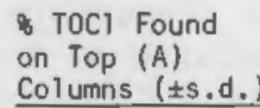

Ether Extracts Tntake Samples $(n=6)$ Discharge Samples $(n=9)$

Base-Neutrals (Heptane Concentrate) Intake and Discharge $(n=14)$
Columns ( \pm s.d.)

$$
50
$$

$78 \pm 21$

$77 \pm 13$
Range of $: T O C l$

Found on Top (A)

Columns

$$
\begin{aligned}
& 32-100^{(a)} \\
& 59-90 \\
& 61-89
\end{aligned}
$$

B. Agreement Between Duplicate Analyses

$\begin{aligned} & \text { Average } 8 \\ & \text { Standard Error } \\ & \text { ( } \pm \text { s.d.) }\end{aligned}$
$\begin{gathered}24 \\ 17^{2} \pm 9 \\ 22 \pm 13\end{gathered}$

Range of \% Standard Error

Ether Extracts

Intake Samples $(n=8)$

Discharge Samples $(n=5)$

Base-Neutrals (Heptane Concentrate) Intake and Discharge Samples

(a) 3 samples were $100 \%$ 
from the mean of about $20 \%$. Data from intake ether extracts would not allow computation of a meaningful standard deviation as indicated by the wide range of values obtained. This variability results from the very low chlorine concentrations in these samples.

Our previous study of the halogenated products from chlorinated natural waters showed that the majority of the organohalogen found on XAD-2 columns was haloform halogen (Bean et a1., 1980). Inspection of the data collected in Table 15 show that, in general, this is not the case for those plants that use cooling towers. A comparison of haloform $\mathrm{TOCl}$ with $\mathrm{TOCl}$ in the ether extract at Duane Arnold, Arkansas Unit No. 2, Trojan, and Palisades shows that a preponderance of the TOCl is not haloform halogen. Comparison of haloform halogen to $n$-heptane concentrate $\mathrm{TOCl}$ leads to the same conclusion at Hatch and Beaver Valley. On the other hand, the two once-through cooled plants have haloform halogen values that account for over half the TOCl in the ether extract. The difference in the haloform halogen/total halogen ratio between the two types of plants is explained by the cooling tower operation as discussed in the previous sections on volatiles and phenols. The towers vent the volatile haloforms while concentrating the nonvolatile nonhaloform halogen-containing components.

\subsubsection{Nature of the Base-Neutral Fraction}

The nature of the nonhalogen, nonphenolic organohalogen material trapped on XAD-2 resins (the base-neutral organohalogen) has been the subject of intense investigation, not only in our laboratories, but in a number of other laboratories as well without marked success. W. H. Glaze has headed a lengthy and diligent research study of the composition of halogenated organics for the Environmental Protection Agency (Glaze, et al., 1982) which focused primarily on chlorinated waste waters. In spite of extensive GC/MS investigations of water chlorinated to levels as high as $2000 \mathrm{mg} / \mathrm{L}$, only a handful of base-neutral components were identified. Many of these were chlorinated hydrocarbons. These would not be expected to be found in measurable concentrations in natural waters chlorinated at $2 \mathrm{mg} / \mathrm{L}$, because of the very low rates observed for aqueous chlorination of aromatic hydrocarbons (Carlson et al., 1975), and because of a general unavailability of hydrocarbon substrate in environmental waters. Another group which has studied the chlorination of seawater is that of J. H. Carpenter. A recent report to the EPA (Carpenter, et al., 1981) reported the formation of some $\mathrm{N}$-bromo amine compounds (these would be destroyed by our addition of sodium sulfite before sampling), but did not report identification of compounds which would fall into the general category of base-neutral organohalogen. In a recent study of three once-through power plants in the Tennessee Valley Authority system, Seaman et al. (1983) reported analysis of the discharge waters for 46 different halogenated compounds, including 12 base-neutral compounds. Only 7 of the 46 compounds were found, and only two (2-chlorophenol and dichlorobenzene) were base-neutrals. We have found dichlorobenzene to be ubiquitous in natural waters at trace 
levels, both in the present studies, and in our studies of natural water chlorination (Bean et al., 1980). All intake and discharge waters examined by GC/MS in this study were found to contain dichlorobenzene.

Thus, there is little information available about the nature of the base-neutral fraction from chlorinated water. Glaze et al. (1980), showed that XAD-2 resin does not collect all the chlorinated organic material from the water; activated charcoal was shown to give much higher values for total organic chlorine than the XAD adsorption method. The analysis of charcoal-adsorbed organohalogen is conducted by combustion of the charcoal pellet because much of the adsorbed material is irreversibly adsorbed. Our use of XAD resins is based upon a large body of evidence presented by Junk et al. (1974) that lipophilic compounds in water, with molecular sizes small enough to be biologically active, and capable of analysis by chromatographic methods, should be retained on XAD-2 columns. XAD columns appear to be intermediate between $n$-hexane and activated charcoal in their ability to remove organohalogenation products from water. Table 17 shows the results obtained from hexane extracts of power plant cooling waters. In all cases, the organic halogen in terms of $\mu \mathrm{g}$ chlorine/L water extracted is less than that found for the XAD-2 columns (compare with ether extracts on Table 15). The environmental "grab" samples were not significantly different from those obtained directly from our sample barrel.

TABLE 17. Total Non-Volatile Organic Chlorine in Power Plant Waters by Hexane Extraction (Values given as $\mu \mathrm{g}$ equivalent chlorine per liter of water \pm range)

\begin{tabular}{|c|c|c|c|}
\hline Power Plant & Sample & $\begin{array}{c}\text { From Sampling } \\
\text { Barre1 }\end{array}$ & $\begin{array}{l}\text { Environmental } \\
\text { "Grab" Sample }\end{array}$ \\
\hline Duane Arnold & $\begin{array}{l}\text { Intake } \\
\text { Discharge } \\
\text { Effluent Plume }\end{array}$ & $\begin{array}{c}n d(a) \\
0.6 \pm 0.2 \\
=\end{array}$ & $\begin{array}{l}\text { nd } \\
0.7^{ \pm} \pm 0.3 \\
0.4(b)\end{array}$ \\
\hline Millstone & $\begin{array}{l}\text { Intake } \\
\text { Discharge } \\
\text { Effluent Plume }\end{array}$ & $\begin{array}{r}0.2(b) \\
1.6 \pm 0.1 \\
=\end{array}$ & $\begin{array}{r}0.5 \pm 0.4 \\
1.6(\mathrm{~b}) \\
0.3(\mathrm{c})\end{array}$ \\
\hline Arkansas & $\begin{array}{l}\text { Intake } \\
\text { Unit } 1 \text { Discharge } \\
\text { Unit } 2 \text { (Twr) Discharge } \\
\text { Mixed Discharge } \\
\text { Effluent Plume }\end{array}$ & $\begin{array}{l}0.6 \pm 0.1 \\
1.2 \pm 1.0 \\
1.0 \pm 0.1 \\
0.5 \pm 0.2 \\
=\end{array}$ & $\begin{array}{l}n d(c) \\
2.8 \pm 2.0(d) \\
0.9 \pm 0.0(d) \\
1.2 \pm 0.7 \\
1.4 \pm 1.1\end{array}$ \\
\hline Hatch & $\begin{array}{l}\text { Intake } \\
\text { Discharge }\end{array}$ & $\begin{array}{l}1.0 \pm 0.1 \\
0.5 \pm 0.1\end{array}$ & \\
\hline Beaver Valley & $\begin{array}{l}\text { Intake } \\
\text { Tower } \\
\text { Discharge }\end{array}$ & $\begin{array}{l}\text { nd } \\
0.6 \pm 0.5 \\
0.4 \pm 0.0\end{array}$ & \\
\hline Trojan & $\begin{array}{l}\text { Intake } \\
\text { Tower } \\
\text { Discharge }\end{array}$ & $\begin{array}{l}\text { nd } \\
0.6 \pm 0.5 \\
0.3 \pm 0.1\end{array}$ & \\
\hline Palisades & $\begin{array}{l}\text { Intake } \\
\text { Tower } \\
\text { Discharge }\end{array}$ & $\begin{array}{l}\text { nd } \\
0.3^{\text {nd }} \pm 0.1 \\
0.3 \pm 0.1\end{array}$ & \\
\hline
\end{tabular}

(a) $\mathrm{nd}=$ not detected in any of the replicate samples

(b) One replicate $(n=3)$ contained less than detectable amounts

(c) Two replicates $(n=3)$ contained less than detectable amounts

(d) One replicate was higher than $10 \mathrm{mg} / \mathrm{L}$ and was discarded from the data set 
Glaze et al. (1980) and Selah and Mokti (1983) have studied the distribution of organohalogen material derived from natural and waste water sources both with respect to polarity and molecular weight. These studies have indicated that the chlorine is distributed throughout a wide size and polarity range. Glaze et al. (1980) have also shown that chlorination dramatically lowers the total amount of organic material that is trapped on XAD-2 resins. Our experiments with silica gel chromatography, summarized in Table 18, indicate that much of the organohalogen material in the n-heptane fraction is relatively polar in nature. About 25\% of the halogen in the Millstone heptane concentrate was recovered in the n-hexane (nonpolar) fraction (Table 18). However, all the bromoform is not removed from the heptane concentrate during the evaporation process; hence, one would expect elution of the nonpolar bromoform in the hexane eluate. Discounting the bromoform content in the Millstone sample, inspection of the data in Table 18 reveals that most of the halogenated organic material in the samples derived from chlorinated water is found in the most polar fraction (100\% ether eluate) or is not recovered from the silica gel column at all.

TABLE 18. Total Organic Halogen in Silica Gel Chromatography Fractions From XAD-2 Samples (Values expressed as micrograms chlorine per liter of water)

\begin{tabular}{|c|c|c|c|c|c|c|c|}
\hline & \multicolumn{6}{|c|}{ Silica Gel Fractions } & \multirow{2}{*}{$\begin{array}{c}\text { TOCl } \\
\text { Recovered }\end{array}$} \\
\hline & Heptane & Conc. & Hexane & $20 / 80$ & Hex/Ether & Ether & \\
\hline \multicolumn{8}{|l|}{ Duane Arnold } \\
\hline Intake & $0.98 \pm$ & 0.05 & - & 0.01 & \pm 0.00 & $0.43 \pm 0.02$ & 45 \\
\hline $\begin{array}{l}\text { Discharge } \\
\text { Millstone }\end{array}$ & $2.66 \pm$ & 0.10 & - & 0.07 & \pm 0.00 & $2.04 \pm 0.31$ & 79 \\
\hline Intake & $0.40 \pm$ & 0.01 & $0.08 \pm 0.02$ & 0.05 & \pm 0.01 & $0.37 \pm 0.03$ & 125 \\
\hline Di scharge & $4.37 \pm$ & 0.45 & $1.13 \pm 0.13$ & 0.24 & \pm 0.03 & $0.48 \pm 0.03$ & 42 \\
\hline \multirow{5}{*}{$\begin{array}{l}\text { Arkansas } \\
\text { Intake } \\
\text { Unit } 2 \text { (Biwdwn) } \\
\text { Unit } 1 \text { Disch. } \\
\text { Mixed Disch. }\end{array}$} & & & & & & & \\
\hline & $0.13 \pm$ & 0.01 & $<0.01$ & 0.08 & $3 \pm 0.00$ & $0.05 \pm 0.00$ & 100 \\
\hline & $0.88 \pm$ & 0.14 & $0.04 \pm 0.00$ & 0.19 & \pm 0.01 & $0.36 \pm 0.20$ & 67 \\
\hline & $1.21 \pm$ & 0.28 & $0.05 \pm 0.00$ & 0.05 & \pm 0.00 & $0.14 \pm 0.01$ & 20 \\
\hline & $0.53 \pm$ & 0.05 & $0.02 \pm 0.00$ & 0.05 & \pm 0.01 & $0.08 \pm 0.01$ & 28 \\
\hline
\end{tabular}

The high degree of polarity found for most of the base-neutral material may be a partial explanation for our failure to elute halogenated products from our chromatographic column during the analys is by GC/MS. Other than the dichlorobenzenes which were found present in all water samples we inspected, very few GC/MS peaks yielding spectra with characteristic halogen isotope clusters. Table 19 summarizes the results of spectral searching of base-neutral fractions for halogenated compounds. As can be seen, few peaks containing halogen clusters were found, and even fewer halogen-containing peaks were found that did not have the same material in the intake sample. Of the compounds found in the search, only one has been tentatively identified. Dibromoiodomethane was found to be present in the Arkansas tower and the Millstone 
discharge at concentrations less than $0.1 \mu \mathrm{g} / \mathrm{L}$. The identity was established by comparison of the spectra (see Appendix D) with the published spectra of dichloroiodomethane (Thomas et al., 1980) which, in addition to the molecular ion, has major fragments corresponding to $\mathrm{I}^{+}$ $(\mathrm{M}=127)$ and $\mathrm{CHCl}_{2}^{+}(\mathrm{M}=83)$. The dibromoiodo compound has $\mathrm{I}^{+}$and $\mathrm{CHBr}_{2}^{+}$ $(M=171)$. The other unidentified components were also found in less than $0.1 \mu \mathrm{g} / \mathrm{L}$ concentrations. Spectra of all base-neutral components found in chlorinated power plant water, but not in intake water are presented in Appendix D.

TABLE 19. Summary of Mass Spectral Search for Halogenated Base-Neutral Compounds

\begin{tabular}{lccc}
\hline Location & $\begin{array}{c}\text { Chromatographic Peaks } \\
\text { Examined for Halogen } \\
\text { Isotope Clusters }\end{array}$ & $\begin{array}{c}\text { Candidates Detected } \\
\text { in Discharge or } \\
\text { Tower Sample }\end{array}$ & $\begin{array}{c}\text { Found in Chlorinated } \\
\text { Water But Not in } \\
\text { in Intake Water }\end{array}$ \\
\hline Duane Arnold & 122 & 5 & 0 \\
Millstone & 97 & 7 & 2 \\
Arkansas Unit $\# 1$ & 34 & 0 & 0 \\
Arkansas Unit \#2 & 127 & $7(a)$ & $7(a)$ \\
Edwin Hatch & 29 & 1 & 0 \\
Beaver Valley & 25 & 1 & 0 \\
Trojan & 36 & 1 & 0 \\
Palisades & 56 & 1 & 0 \\
\hline
\end{tabular}

(a) In two cases, two separate chromatographic peaks were found to have identical spectra

\subsection{Summary of Organohalogen Concentrations Found at Nuclear Power Plants and Calculation of Net Discharges to Receiving Waters}

Sections 3.2 through 3.4 have discussed the individual compounds and types of materials found in chlorinated power plant cooling water discharges. In this section, these findings are summarized in terms of the organic halogen that these discharged materials contain. In addition, the intake and discharge concentrations of organohalogens are combined with plant operating data to estimate the net amount of organohalogen material discharged by each power plant during a typical chlorination cycle.

The data in Table 20 is a summary of the concentrations of volatile, base-neutral, and phenolic organohalogens found in the cooling waters at the seven power plants studied. Volatile organic chlorine concentrations were calculated from the volatiles analys is in Section 3.2. Phenol organic chlorine is derived from the data in Section 3.3. Base-neutral organic chlorine is the "heptane concentrate" data from Section 3.4. In those cases where heptane concentrate organic chlorine 
TABLE 20. Organic Chlorine Found as Haloform, Halophenol and Base/ Neutral Material in Power Plant Water. (Concentrations in $\mu g$ chlorine per liter of water)

\begin{tabular}{|c|c|c|c|c|c|c|}
\hline & $\begin{array}{l}\text { A } \\
\text { Volatile } \\
\text { Organo- } \\
\text { Chlorine }\end{array}$ & $\begin{array}{l}\text { B } \\
\text { Base/Neut. (a) } \\
\text { Organo- } \\
\text { Chlorine }\end{array}$ & $\begin{array}{l}\text { C } \\
\text { Phenol } \\
\text { Organo- } \\
\text { Chlorine }\end{array}$ & $\begin{array}{l}\text { Sum } \\
\text { of } \\
A+B+C\end{array}$ & $\begin{array}{c}T O C 1 \text { in } \\
\text { XAD-2 } \\
\text { Extract }\end{array}$ & $\begin{array}{c}\text { TOCl } \\
\text { Accounted } \\
\text { for by } \\
\text { Ether Extract }\end{array}$ \\
\hline \multicolumn{7}{|l|}{ Duane Arnold } \\
\hline Intake & nd & 1.0 & $\operatorname{tr}(b)$ & 1.0 & 1.0 & 100 \\
\hline Discharge & 0.4 & 2.8 & 0.6 & 3.8 & 1.9 & 50 \\
\hline \multicolumn{7}{|l|}{ Mills stone Unit \#2 } \\
\hline Tntake & nd & 0.5 & $\operatorname{tr}$ & 0.5 & 1.1 & 220 \\
\hline Discharge & 1.7 & 2.9 & 0.1 & 4.7 & 5.4 & 114 \\
\hline \multicolumn{7}{|l|}{ Arkansas } \\
\hline $\begin{array}{l}\text { Tntake } \\
\# 1 \text { (Once-Thru) }\end{array}$ & 0.1 & 0.2 & $\begin{array}{l}\operatorname{tr} \\
\operatorname{tr}\end{array}$ & $\begin{array}{l}0.3 \\
3.0\end{array}$ & $\begin{array}{l}0.6 \\
2.7\end{array}$ & $\begin{array}{r}200 \\
90\end{array}$ \\
\hline $\begin{array}{l}\# 1 \text { (Once-Thru) } \\
\text { \#2 (Tower) }\end{array}$ & $\begin{array}{l}1.9 \\
1.5\end{array}$ & $\begin{array}{l}1.1 \\
1.4\end{array}$ & 0.3 & 3.2 & 4.2 & 131 \\
\hline Mixed Discharge & 3.4 & 0.7 & tr & 4.1 & 3.1 & 76 \\
\hline \multicolumn{7}{|l|}{ Edwin Hatch Unit \#2 } \\
\hline Intake & nd & 0.3 & nd & 0.3 & $(23)^{(c)}$ & - \\
\hline Discharge & 0.7 & 0.9 & $<0.1(.05)$ & 1.6 & (8) & - \\
\hline \multicolumn{7}{|l|}{ Beaver Valley Unit \#1 } \\
\hline Tntake & 1.0 & 1.5 & $\operatorname{tr}$ & 2.5 & $(12)^{(1)}$ & - \\
\hline $\begin{array}{l}\text { Tower } \\
\text { Discharge }\end{array}$ & 1.5 & 1.2 & 0.2 & 2.9 & (9) & - \\
\hline \multicolumn{7}{|l|}{ Trojan } \\
\hline Intale & 0.6 & 0.9 & $<0.1(.04)$ & 1.5 & 0.9 & 60 \\
\hline Tower & 7.3 & 3.2 & 1.7 & 11.2 & 12.2 & 109 \\
\hline Discharge & 2.6 & 1.1 & 0.2 & 3.9 & 3.2 & 82 \\
\hline \multicolumn{7}{|l|}{ Palisades } \\
\hline Intake & 0.7 & 0.2 & nd & 0.9 & 0.8 & 89 \\
\hline Tower & 1.8 & 1.9 & 0.1 & 3.8 & 6.1 & 161 \\
\hline Discharge & 3.5 & 1.9 & 0.1 & 5.5 & 6.2 & 113 \\
\hline
\end{tabular}

(a) Base/neutral TOCl is the TOCl found in the heptane concentrate of the XAD ether extracts after phenols were removed

(b) $\operatorname{tr}=\operatorname{trace}(>0.01 \mu \mathrm{g} / \mathrm{L})$

(c) Beaver Valley and Hatch XAD columns were found to be contaminated with a volatile substance that interferred with TOC determination

or TOCl measurements were not available for bottom XAO columns (see Tables $15 \mathrm{~A}, \mathrm{~B}$, and $\mathrm{C}$ ), the average extraction efficiency determined for the top XAO columns (see Table 16) was used to estimate the total of top and bottom columns. Both TOX and base-neutral data in Table 20 are reported for the sum of top and bottom XAD columns. The concentrations for each of the categories listed are expressed in terms of the quantity of chlorine required to manufacture the material found. For example, $3.7 \mu \mathrm{g} / \mathrm{L}$ of bromoform and $0.2 \mu \mathrm{g} / \mathrm{L}$ dibromochloromethane were found in the Millstone discharge. The quantity of chlorine added to the cooling water, which was used to make those haloforms, was $1.7 \mu \mathrm{g} / \mathrm{L}$ and that figure is reported in Table 20. The same procedure was used to summarize the concentrations of halophenol halogen reported in Table 20. The organic halogen reported for the base-neutral fraction was determined directly by microcoulometer and is also expressed in terms of $\mu \mathrm{g} \mathrm{Cl} / \mathrm{L}$ of water. 
The advantages, in terms of uniformity and intercomparability, of reporting concentrations of organohalogens in terms of $\mu \mathrm{g} \mathrm{Cl} / \mathrm{L}$ have been discussed in Section 3.3. The disadvantages of this method is that the actual quantities of material discharged are not completely represented. For example, the phenol organic chlorine reported in Table 20 is less than half the actual weight of the halogenated phenols found per liter of water analyzed. Concentrations of individual components have been reported in Sections 3.2 through 3.4 of this report.

Non-haloform volatile organohalogen compounds (e.g., trichloroethylene, methylene chloride, etc.) were not included in the summary, Table 20. We found no evidence that these compounds are created by the biocide chlorination process, in either the present study or in our previous studies of chlorinated water (Bean et al., 1980). Concentrations of nonhaloform volatiles were generally much lower than haloforms in discharge waters. An assumption made in Table 20 is that the haloforms originally present in the XAD-2 ether extracts used to isolate the base-neutral fraction were eliminated by evaporation of $n$-heptane during the concentration step. To the extent that some higher molecular weight haloforms remain unevaporated, the organohalogen figures are high. At most locations, the predominant haloform product was the volatile haloform chloroform, hence any errors due to unevaporated haloforms are low. However, Millstone discharge contained bromoform almost exclusively, thus, the organohalogen due to the bromoform in the Millstone heptane concentrate was subtracted from the $n$-heptane concentrate $\mathrm{TOCl}$ and the difference reported as the base-neutral organohalogen.

Because of the different water sources, types of cooling, chlorination practices, and different concentrations of chlorine used, it is difficult to generalize with the data in Table 20. A direct comparison between the discharges of Arkansas Unit \#1 (once-through cooling) and Arkansas Unit \#2 (tower cooling) demonstrates that towers act to evaporate volatile halogenated constituents and concentrate the nonvolatile halogen because only about half the organohalogen was haloform in the Unit \#2 discharge, but two-thirds to three-quarters was haloform in the discharge from Unit \#1. Organohalogen concentrations in both Unit \#1 and Unit \#2 were quite similar considering that chlorine concentration in the Arkansas cooling tower was about five times the concentration used for chlorination of the once-through cooling water. Duane Arnold discontinues blowdown for many hours before discharging from its tower. The result is very low haloform concentrations compared to total organic halogen discharged. Trojan had the highest haloform and halophenol concentrations measured at any plant; they chlorinated at the highest level $(6 \mathrm{mg} / \mathrm{L})$ of all plants studied and for a relatively long period of 70 minutes. The lower concentrations of organohalogen in the discharge of many tower-cooled plants is a result of dilution. Thus, the Arkansas Unit \#2 tower blowdown is less than $1 \%$ of the total discharge from Unit \#1 mixed discharge. Palisades and Trojan dilute their cooling water substantially prior to discharge. Millstone, a once-through marine facility, dilutes its discharge four-fold, because only one of four condensers is chlorinated at a time. Discharge concentrations reported for Palisades are higher than actual because of 
actual quantities of material discharged are not completely represented. For example, the phenol organic chlorine reported in Table 19 is less than half the actual weight of the halogenated phenols found per liter of water analyzed. Concentrations of individual components have been reported in Sections 3.2 through 3.4 of this report.

Non-haloform volatile organohalogen compounds (e.g., trichloroethylene, methylene chloride, etc.) were not included in the summary, Table 20. We found no evidence that these compounds are created by the biocide chlorination process, in either the present study or in our previous studies of chlorinated water (Bean et al., 1980). Concentrations of nonhaloform volatiles were generally much lower than haloforms in discharge waters. An assumption made in Table 20 is that the haloforms originally present in the XAD-2 ether extracts used to isolate the base-neutral fraction were eliminated by evaporation into $n$-heptane during the concentration step. To the extent that some higher molecular weight haloforms remain unevaporated, the organohalogen figures are high. At most locations, the predominant haloform product was the volatile haloform chloroform, hence any errors due to unevaporated haloforms are low. However, Millstone discharge contained bromoform almost exclusively, thus, the organohalogen due to the bromoform in the Millstone heptane concentrate was subtracted from the $n$-heptane concentrate TOCT and the difference reported as the base-neutral organohalogen.

Because of the different water sources, types of cooling, chlorination practices, and different concentrations of chlorine used, it is difficult to generalize with the data in Table 20. A direct comparison between the discharges of Arkansas Unit \#1 (once-through cooling) and Arkansas Unit \#2 (tower cooling) demonstrates that towers act to evaporate volatile halogenated constituents and concentrate the nonvolatile halogen because only about half the organohalogen was haloform in the Unit \#2 discharge, but two-thirds to three-quarters was haloform in the discharge from Unit \#1. Organohalogen concentrations in both Unit \#1 and Unit \#2 were quite similar considering that chlorine concentration in the Arkansas cooling tower was about five times the concentration used for chlorination of the once-through cooling water. Duane Arnold discontinues blowdown for many hours before discharging from its tower. The result is very low haloform concentrations compared to total organic halogen discharged. Trojan had the highest haloform and halophenol concentrations measured at any plant; they chlorinated at the highest level $(6 \mathrm{mg} / \mathrm{L})$ of all plants studied and for a relatively long period of 70 minutes. The lower concentrations of organohalogen in the discharge of many tower-cooled plants is a result of dilution. Thus, the Arkansas Unit \#2 tower blowdown is less than $1 \%$ of the total discharge from Unit \#1 mixed discharge. Palisades and Trojan dilute their cooling water substantially prior to discharge. Millstone, a once-through marine facility, dilutes its discharge four-fold, because only one of four condensers is chlorinated at a time. Discharge concentrations reported for Palisades are higher than actual because of 
the poor mixing of discharged chlorinated water with unchlorinated water existing at our sampling point. Concentrations actually discharged could be as much as $50 \%$ lower than reported.

Concentrations of total organohalogen discharged by the seven power plants can either be calculated by summing up the volatile, base-neutral, and phenolic organohalogen (Table 20, column 4), or directly measured in the XAD-2 column ether extract (column 5). A comparison of these two measures of total organic halogen is given in the last column of Table 20 . The general agreement between these two values is gratifying, particularly when the errors inherent in the determinations are considered. The measurement of Tox in the ether extract is based on a microcoulometric measurement of organic chlorine at the few parts-per-million level, close to the bottom of the useful measurement range. There are errors inherent in the halogen determination for each of the three fractions (volatiles, base-neutrals, phenols) used for the calculation of the TOX. The agreement is not as good for the intake samples where concentrations of TOX determined by each method differ by a factor of two for the first three plants listed in Table 20. The higher figure for the ether extracts may be due to trace quantities of volatile halogen components too low in concentration to be found by the purge-and-trap method, but which collectively add to the TOX adsorbed on the XAD-2 samiple.

The range of halogen concentrations found in the discharges of the power plants was 1.6 to $6.2 \mu \mathrm{g} \mathrm{Cl/L}$ water sampled. To place these discharge concentrations in perspective, we might consider what this means in terms of total quantity discharged. If the maximum concentration found $(6.2 \mu \mathrm{g} \mathrm{Cl/L})$ was discharged at the maximum water discharge rate found for all of the plants studied (Arkansas at $720,000 \mathrm{gal} / \mathrm{min}$ ), the quantity discharged per hour would be about $1 \mathrm{~kg}(2.2 \mathrm{lb})$. Because there already is some organohalogen material in the intake waters, the net discharge would be less.

All of the plants studied discharge organohalogen at considerably smaller rates than $1 \mathrm{~kg} / \mathrm{hr}$. The net discharges (chlorine out less chlorine in) have been estimated using the results in Table 20, plant operating data in Table 2, and, where necessary, analytically deternined tower concentration factors given in Table 4 . The results of these net discharge calculations are shown in Table 21.

The assumptions made in estimating the net discharges for tower-cooled plants were that the quantity of organic chlorine discharged by the plant was the product of the concentration of organochlorine found in the cooling tower basin (or undiluted blowdown) and the volume of the cooling water system (Table 2). The volume of intake water required to create the water present in the cooling water system is much larger than the volume of the cooling water system. This is because of large water losses to evaporation and drift. Thus, the quantity of organohalogen 
TABLE 21. Net Discharge of Chlorinated Organics From Nuclear Power Units (Expressed as grams chlorine per chlorination cycle)

\begin{tabular}{|c|c|c|c|c|c|c|c|c|}
\hline & $\begin{array}{l}\text { Duane } \\
\text { Arnold }\end{array}$ & $\begin{array}{l}\text { Millstone } \\
\text { Unit } \# 2\end{array}$ & $\frac{\text { Arkansas }}{\text { Unit } \# 1}$ & $\frac{\text { Nuclear One }}{\text { Unit } \$ 2}$ & $\begin{array}{l}\text { Hatch } \\
\text { Unit } \# 2\end{array}$ & $\begin{array}{c}\text { Beaver Valley } \\
\text { Unit } \# 1\end{array}$ & Trojan & Palisades \\
\hline $\begin{array}{l}\text { Chlorine added, } \mathrm{kg} \\
\text { Vol., water chlorin., L } \\
\text { Concentration factor }\end{array}$ & $\begin{array}{c}275 \\
9.5 \times 10^{6} \\
4.4\end{array}$ & $\begin{array}{c}270 \\
497 \times 10^{6} \\
1\end{array}$ & $\begin{array}{c}114 \\
54.4 \times 10^{6} \\
1\end{array}$ & $\begin{array}{l}57 \\
15 \times 10^{6} \\
4.6\end{array}$ & $\underset{2}{57} \times(8)$ & $\begin{array}{r}114 \\
45 \times 10^{6} \\
1.1\end{array}$ & $\begin{array}{c}114 \\
19 \times 10^{6} \\
3.6\end{array}$ & $\begin{array}{c}36 \\
19 \times 10^{6} \\
1.2\end{array}$ \\
\hline Haloforms & (1) & & & & & & & \\
\hline $\begin{array}{l}\text { g Cl taken in } \\
\text { g Cl discharged } \\
\text { Net g Cl discharged as }\end{array}$ & $\operatorname{neg}_{4}(a)$ & $\begin{array}{l}\text { neg } \\
840\end{array}$ & $\begin{array}{r}5 \\
103\end{array}$ & $\begin{array}{r}7 \\
23\end{array}$ & $\begin{array}{l}\text { neg } \\
49\end{array}$ & $\begin{array}{l}50 \\
36\end{array}$ & $\begin{array}{r}40 \\
140\end{array}$ & $\begin{array}{l}16 \\
34\end{array}$ \\
\hline $\begin{array}{l}\text { hal of orm } \\
\text { Base-Neutrals } \\
\end{array}$ & 4 & 840 & 98 & 16 & 49 & -14 & 100 & 18 \\
\hline $\begin{array}{l}\text { g } \mathrm{Cl} \text { taken in } \\
\mathrm{g} \mathrm{Cl} \text { discharged } \\
\text { Net g } \mathrm{Cl} \text { discharged as }\end{array}$ & $\begin{array}{l}42 \\
26\end{array}$ & $\begin{array}{r}250 \\
1450\end{array}$ & $\begin{array}{l}11 \\
60\end{array}$ & $\begin{array}{l}14 \\
21\end{array}$ & $\begin{array}{l}27 \\
63\end{array}$ & $\begin{array}{l}75 \\
91\end{array}$ & $\begin{array}{l}60 \\
60\end{array}$ & $\begin{array}{r}4 \\
36\end{array}$ \\
\hline $\begin{array}{l}\text { base + neutrai } \\
\text { Chlorophenols }\end{array}$ & -16 & 1200 & 49 & 7 & 36 & 16 & 0 & 32 \\
\hline $\begin{array}{l}\text { g } \mathrm{Cl} \text { taken in } \\
\mathrm{g} \mathrm{Cl} \text { discharged } \\
\text { Net } \mathrm{g} \mathrm{Cl} \text { di scharged as }\end{array}$ & $\operatorname{neg}_{6}$ & $\begin{array}{r}\text { neg } \\
50\end{array}$ & $\begin{array}{l}\text { neg } \\
\text { neg }\end{array}$ & $\underset{5}{n e g}$ & $\underset{3}{\text { neg }}$ & neg & $\begin{array}{r}\text { neg } \\
30\end{array}$ & neg \\
\hline chilorophenol & 6 & 50 & - & 5 & 3 & 9 & 30 & 2 \\
\hline $\begin{array}{l}\text { Total organochlorine } \\
\text { discharged, } g\end{array}$ & -6 & 2090 & 147 & 28 & 88 & 11 & 130 & 52 \\
\hline $\begin{array}{l}\text { of added chlorine } \\
\text { accounted for }\end{array}$ & 0 & 0.77 & 0.13 & 0.05 & 0.15 & 0.01 & 0.11 & 0.14 \\
\hline
\end{tabular}

(a) neg = negligible quantities

(b) Concentration factor in discharge was found to be 1.3 . Concentration tower basin was calculated by multiplying discharge concentration by $\frac{2}{1.3}$ 
taken in by the plant to create the volume of water actually chlorinated is equal to the product of the cooling water system volume and the concentration factor of the tower system. Therefore:

$$
x_{\text {net }}=\mathrm{Cl}_{\text {twr }} \times V_{\mathrm{CW}}-\mathrm{Cl}_{\text {in }} \times V_{\mathrm{CW}} \times \mathrm{CF}
$$

where $X_{\text {net }}$ is the net quantity of organic halogen discharged (measured as grams of chlorine), $\mathrm{Cl}_{\text {twr }}$ and $\mathrm{Cl}_{\text {in }}$ are the concentrations $(\mathrm{g} / \mathrm{L})$ of organohalogen in tower and intake waters, $V_{C W}$ is the volume of the cooling water system (L) and CF is the tower concentration factor defined in Section 3.1. Since the tower basin concentrations of organic halogen material were not measured at the Hatch plant, the tower concentrations were calculated by the expression:

$$
c_{\text {twr }}=c_{\text {disch }} \times \frac{C F_{\text {twr }}}{C F_{\text {disch }}}
$$

where $C_{\text {twr }}$ and $C_{\text {disch }}$ are organohalogen concentrations in tower and discharge, respectively, and $\mathrm{CF}_{\text {twr }}$ and $\mathrm{CF}_{\text {disch }}$ are the concentration factors determined from fluoride ion measurements (Table 3 ) in tower and discharge, respectively. Calculations for once-through plants were:

$$
x_{\text {net }}=\left(\mathrm{Cl}_{\text {disch }}-C 1_{\text {in }}\right) \times \mathrm{R}_{\mathrm{CW}} \times \mathrm{T}
$$

where $\mathrm{Cl}_{\text {disch }}$ is the organochlorine concentration in the intake $(\mathrm{g} / \mathrm{L})$, $R_{\mathrm{CW}}$ the cooling water flow rate $(\mathrm{L} / \mathrm{min})$, and $T$ is time in minutes.

The assumption made for cooling towers is complicated by the fact that the towers continue to to take in fresh water and lose water through evaporation, drift, and (usually) blowdown during the chlorination period. These perturbations are neglected since the water turnover is only a fraction of the cooling water system volume during the chlorination time.

The results presented in Table 21 indicate that net discharges of organohalogens are generally lower per chlorination cycle from the plants using cooling towers than from plants with once-through cooling. The larger total discharge from the once-through plant at Milistone (2 $\mathrm{kg} / \mathrm{cycle})$ than the fresh water once-through plant at Arkansas $(0.15$ $\mathrm{kg} / \mathrm{cycle}$ ) is partly because of higher quantities of chlorine used and partly because a higher percentage of chlorine was used to produce organohalogen material $(0.77 \%$ vs. $0.13 \%)$. The percentages of chlorine used to produce volatile and XAD-2 adsorbable organohalogens of these 
once-through plants are consistent with our previous studies of natural water chlorination (Bean et al., 1980). Duane Arnold, because of its unique operation appears to remove more chlorine from the Cedar River than it produces from the chlorination process. It should be remembered that several authors (Jolley et al., 1978; Smith, et al., 1983), as well as data included in this report, have presented evidence that a substantial fraction of the haloforms produced in cooling towers are lost through evaporation and drift. Therefore, the percentage chlorine converted to organohalogen compounds could actually be significantly higher for tower-cooled plants, because most towers use higher concentrations of chlorine for longer residence times than once-through plants.

The quantities of halogenated organic material added to the aquatic environment from biocide chlorination at nuclear power plants are quite small when the size of their operations in terms of water use and electrical output is considered. Additional perspective on the quantities of organohalogens discharged from the eight power units studied is presented in Table 22, where the total quantities of haloforms and halophenols produced per normal chlorination day are given. Millstone plant has the highest discharges because it chlorinates three times a day, uses more chlorine per cycle than the other plants, is a once-through cooled plant, and converts a higher percentage of chlorine to chlorinated organics. The total amount of haloforms discharged by Millstone into the open ocean per day of chlorination is estimated to be $5.8 \mathrm{~kg}(13 \mathrm{lb})$ and of halogenated phenols, $0.7 \mathrm{Kg}(1.5 \mathrm{lb})$. Other plants, either because of lower chlorine usage, cooling tower operation, or both, discharge much lower quantities of haloforms and halophenols to the environment.

TABLE 22. Estimated Net Daily Discharge of Haloforms and Halogenated Phenols by Nuclear Power Plants (Expressed as grams/day of chlorination)

\begin{tabular}{lrc}
\hline & Haloforms & Halophenols \\
Duane Arnold & 4 & 13 \\
Millstone Unit \#2 & 5800 & 660 \\
Arkansas Unit \#1 & 141 & $<2$ \\
Arkansas Unit \#2 & 70 & 17 \\
Edwin Hatch Unit \#2 & 160 & 12 \\
Beaver Valley Unit \#1 & 67 & 22 \\
Trojan & 120 & 75 \\
Palisades & 28 & 5 \\
\hline
\end{tabular}




\section{ANALYSIS OF SEDIMENTS FROM DISCHARGE PLUMES AND CONTROL SEDIMENTS}

Sediment cores were taken at the first three power plants for the purpose of determining the feasibility of using total organic halogen measurements to define the area of impact of chlorinated power plant discharge plumes. Several factors led to placing more effort on the sampling and analysis of sediments at the last three power plants sampled. The preliminary results appeared to indicate a positive correlation between sediment location and total organic halogen. Also, we found that halogenated phenols could be a substantial fraction of the chlorinated organic material discharged (Bean et al., 1983) and were shown to be adsorbed on suspended matter (Bean et al., 1982) discharged from a once-through power plant. Further, the observation by Bouwer et al. (1981) (contested later by Flathman and Dahlgren, 1982) that no aerobic conditions could be found for the biodegradation of haloforms, suggested that trihalomethanes might be found in significantly higher concentrations in sediments impacted by power plant discharge plumes than in control sediments. For the more extensive analyses warranted by these developments, bulk samples of sediment were taken in triplicate from both discharge plume and control locations at the Beaver Valley, Trojan, and Palisades power plants in addition to core samples. These samples were analyzed for volatiles, halophenols, and base-neutral halogenated material as described below.

\subsection{Analysis of Sediment for Volatile Organohalogen Compounds}

\subsubsection{Method}

In order to analyze sediment for volatiles, a method was needed which was sensitive to less than $1 \mu \mathrm{g} / \mathrm{L}$ (part-per-billion), and which would permit analysis without excessive disturbance of the sediment sample and without concentration of samples by solvent evaporation. These criteria were required because water analyses (Section 3.2) had shown volatile chiorocarbons to be present in power plant discharges at the $1 \mu \mathrm{g} / \mathrm{L}$ level, and considerations of the relative volatility and water solubility of these compounds suggested that they would not be found in sediments in concentrations much higher than in the water. In addition, excessive sample manipulation or evaporation of sediment solvent extracts would result in unacceptable losses of volatiles.

In view of the above criteria, a modification of the purge-and-trap method used for the analysis of volatile chlorocarbons in water (Section 3.2) was developed for the analysis of sediment. In the usual purgeand-trap method, a water sample is sparged with an inert gas that sweeps the volatiles from the water into a trap containing an organic poiymer, which absorbs the volatiles. Then the trap is heated in a stream of gas which is fed to a chromatographic column for sample analysis by GC/MS. We have modified this method for the analysis of sediments by purging a sediment sample placed in $25 \mathrm{~mL}$ volatile-free water in a manner similar to the water analysis, but at a higher temperature $\left(50^{\circ} \mathrm{C}\right)$ and in the 
presence of uitrasonic energy in order to insure removal of adsorbed volatiles from the sediment sample. The analysis of the volatiles after absorption onto the trap is accomplished by electron capture gas chromatography rather than GC/MS in order to achieve the analytical sensitivity required.

Bulk sediment samples taken in one-quart glass jars were stored at $-70^{\circ} \mathrm{C}$ prior to analysis. They were allowed to thaw at $4^{\circ} \mathrm{C}$ prior to analysis, and the supernatant water removed by pipette. A $10 \mathrm{~g}$ sediment sample was removed by coring with a $13 \mathrm{~mm}$ i.d. glass tube and dropping the core into the preweighed purge apparatus (Figure 18) that was immediately capped and weighed again to determine sample weight. An internal standard (1,3-dibromopropane) was then added in $2 \mu \mathrm{L}$ methanol. The sparger, sintered on the sides of the frit so that air only came from the bottom (Figure 18), was fitted to the purge apparatus, the apparatus placed in the $50^{\circ} \mathrm{C}$ sonicating bath and the trap allowed to collect the purged volatiles for 20 minutes. The trap was then introduced to the electron capture gas chromatograph for thermal desorption and analysis.

The disadvantages of the method are: (1) only about 10 grams of sediment could be analyzed at a time with the apparatus at hand; (2) the method is so sensitive ( $<10$ picograms/gram for many compounds) that it is difficult to obtain a good blank. A flat baseline could not be obtained because of traces of volatiles in our ultra-pure nitrogen

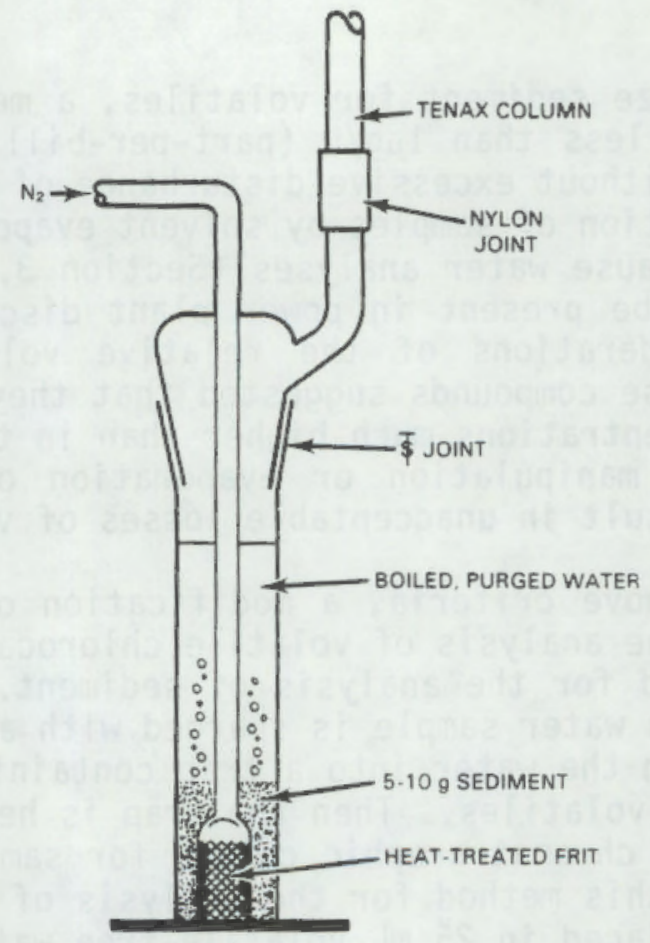

FIGURE 18. Modified Purge-and Trap Apparatus for the Determination of Volatiles in Sediments 
source (Figure 19). Chloroform could only be eliminated from the blank by extensive purging of the system (which contained $25 \mathrm{~mL}$ of ultra-pure water boiled for 30 minutes). Figure 19 also shows a chromatogram obtained from a sediment sample spiked with $1.2 \mathrm{ng}$ of haloform standards. These compounds were of particular interest because of their origin in chlorinated power plant discharges; they are not interfered

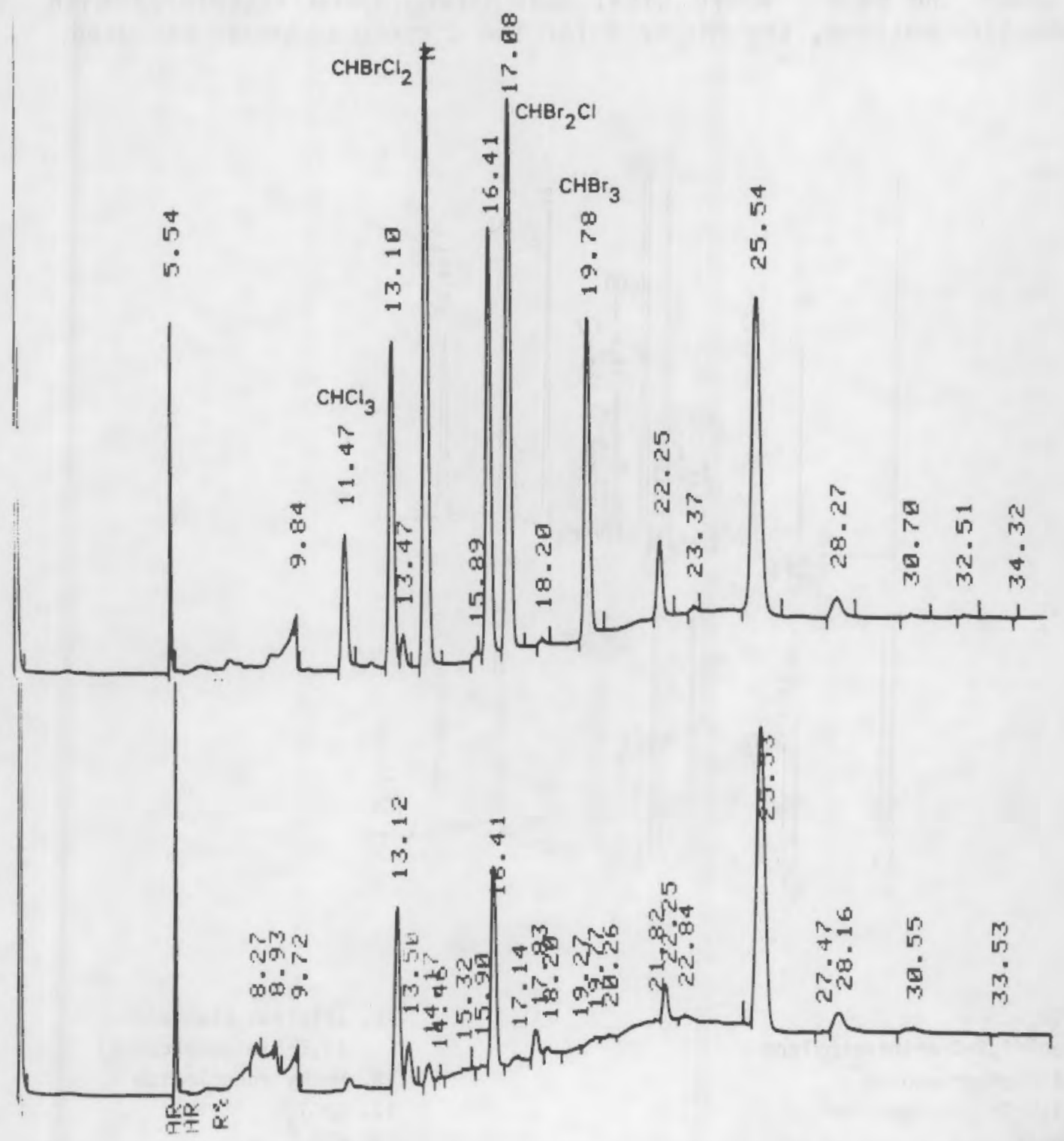

FIGURE 19. Chromatograms of Haloform Standards and a Procedural Blank. Top: Halofrom Standards. $\mathrm{CHCl}_{3}, 1.20 \mathrm{ng}$; $\mathrm{CHBrCl}_{2}, 1.58 \mathrm{ng}$; $\mathrm{CHBr}_{2} \mathrm{Cl}, 1.96 ; \mathrm{CHBr}_{3}, 2,312$. Coefficient of Variation for $\mathrm{n}=5, \mathrm{CHCl}_{3}=4.7 \%, \mathrm{CHBrCl}_{2}=7.1 \%, \mathrm{CHBr}_{2} \mathrm{Cl}=9.5 \%, \mathrm{CHBr}_{3}=18.2 \%$. Recovery from Sediment at These Concentrations was $85 \%$. Bottom: Procedural Blank. 
with by the peaks in the blank. Chromatograms obtained from analytical standards at $8 \mathrm{ng}$ per component are shown in Figure 20. The sensitivities of the compounds to the electron capture detector are highly variable. While methylene chloride is barely evident at this level, carbon tetrachloride gives a very large peak. Some of the components emerge from the chromatographic column at the same time. Fortunately, the responses in the detector of two out of the three co-eluting pairs were about the same. Where cis-1,3-dichloropropene interfered with dibromochloromethane, the response for the dibromo compound was used.
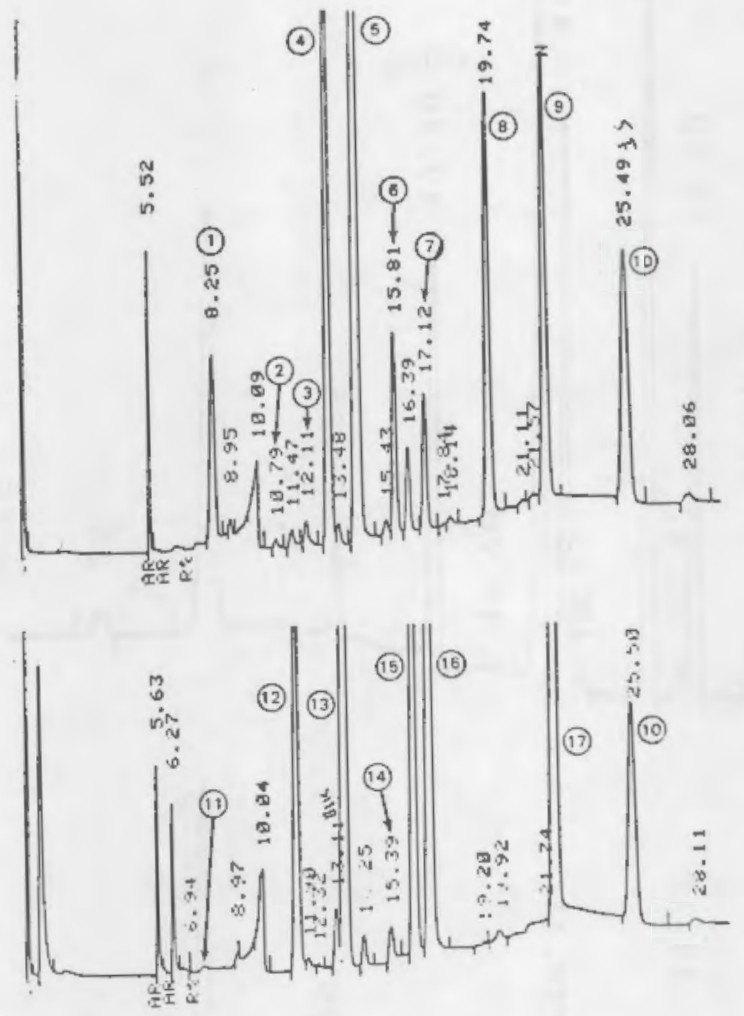

1. $\mathrm{CFCl}_{3}$

2. Trans-1,2-Dichloroethylene

10. Internal Standard (1,3-Dibromopropane)

3. 1,2-Dichloroethane

11. Methylenechloride

4. 1,1,1-Trichloroethane

12. $\mathrm{CHCl}_{3}$

5. $\mathrm{CHBrCl}$

6. Trans-1,3-Dichloropropane

13. $\mathrm{CCl}^{3}$

7. CIS-1,3-Dichloropropane

8. $\mathrm{CHBr}$

9. $1,1,2,2$-Tetrachloroethane

14. 1,2-Dichloropropane

15. Trichloroethylene

16. $\mathrm{CHBr}_{2} \mathrm{Cl}$

17. Tetrachloroethylene

FIGURE 20. Chromatograms of Volatile Halocarbon Standards ( $8 \mathrm{ng}$ per Component) Analyzed by The Electron Capture Purge-and-Trap Technique. 


\subsubsection{Results and Discussion}

The data obtained from bulk sediment samples appear on Table 23. Chromatograms corresponding to the discharge and control sediment analyses for three power plants are shown in Figures 21, 22 and 23. Values for most of the components of interest were well under $1 \mu \mathrm{g} / \mathrm{kg}$ dry sediment (1 part-per-billion) with the exception of methylene chloride and trichlorofluoromethane. Methylene chloride was found at levels between 0.2 and $0.8 \mathrm{mg} / \mathrm{kg}$ (parts-per-million) and appeared in all samples. Trichlorofluoromethane was found at the $1 \mu \mathrm{g} / \mathrm{kg}$ level in four of six locations. We cannot be sure of the identity of the peaks corresponding to these two components because the quantities are too small for GC/MS verification. It is possible that freon was present in the dry ice used to freeze the samples in the field. In any event, these peaks do not appear to be power-plant related, because they were found in both discharge and control sediments.

Core samples were also analyzed for volatiles. Because the possibility of contamination of the bulk sediment samples were indicated when relatively large $(\leq 1 \mathrm{mg} / \mathrm{kg}$ ) concentrations of methylene chloride were found, the cores were sampled by sawing the frozen cores in two, and sampling with the glass core sampler from the sawed ends. By this stratagem, sampling of any contaminants leaking through the core caps into the end portions of the core could be avoided. The results of this analysis are presented in Table 24. Although the peak corresponding to trichlorofluoromethane was found to be absent in all core samples (which indicated that the bulk samples may indeed have been contaminated by refrigeration freons), methylene chloride was again found in the core samples. The only samples that contained more than $20 \mu \mathrm{g} / \mathrm{kg}$ were those taken from the upper portions of the cores, which suggests (but does not conclusively demonstrate) that methylene chloride was actually present in the surface portions of the sediments sampled and were not contaminants.

The data we generated on sediment volatiles does not show any effect from power plant operation. The haloforms, known to be formed from the chlorination of cooling waters, do not predominate in the sediments exposed to the discharge plume and, if present at all, are found in concentrations much less than $1 \mu \mathrm{g} / \mathrm{kg}$. Thus, sediments do not appear to be a major environmental sink for volatile halocarbons. 
TABLE 23. Analysis of Volatile Halocarbons in Bulk Sediment Samples From Power Plant Locations (Concentrations are in micrograms per kilogram of dry sediment)

\begin{tabular}{|c|c|c|c|c|c|c|c|c|}
\hline \multirow[b]{2}{*}{ Component } & \multirow[b]{2}{*}{$\begin{array}{l}\text { Retention } \\
\text { Time }\end{array}$} & \multirow{2}{*}{$\begin{array}{c}\text { Minimum } \\
\text { Detection } \\
\text { Level } \\
(\mu \mathrm{g} / \mathrm{kg})\end{array}$} & \multicolumn{2}{|c|}{ Beaver Valley } & \multicolumn{2}{|c|}{ Palisades } & \multicolumn{2}{|c|}{ Trojan } \\
\hline & & & $\begin{array}{l}\text { Discharge } \\
(n=4)\end{array}$ & $\begin{array}{c}\text { Control } \\
(n=3)\end{array}$ & $\begin{array}{l}\text { Di scharge } \\
\qquad(n=4)\end{array}$ & $\begin{array}{l}\text { Control } \\
(n=3)\end{array}$ & $\begin{array}{l}\text { Discharge } \\
(n=4)\end{array}$ & $\begin{array}{c}\text { Control } \\
(n=2)\end{array}$ \\
\hline Methylene chloride & 6.6 & 20 & $230 \pm 210$ & $890(a)$ & $120 \pm 45$ & $80 \pm 28$ & $220 \pm 200$ & $440 \pm 40$ \\
\hline Trichlorofluoromethane & 8.3 & 0.1 & $1.0-0.7(b)$ & $d(c)$ & nd (d) & nd & $1.7 \pm 0.1(b)$ & $3.2 \pm 3.3$ \\
\hline Trans -1,2-di chl oroethylene & 10.8 & 3.4 & nd & nd & nd & nd & d & nd \\
\hline Chloroform & 11.5 & 0.04 & $0.08 \pm 0.02$ & $0.15 \pm 0.11(b)$ & $0.04 \pm 0.01$ & $0.03 \pm 0.01$ & $0.04 \pm 0.02$ & $0.09 \pm 0.01$ \\
\hline 1,2-Dichloroethane & 12.1 & 1.2 & nd & nd & nd & nd & nd & d \\
\hline $1,1,1$-Trichloroethane & 13.1 & 0.04 & $0.16 \pm 0.16(b)$ & d & $0.13 \pm 0.08(b)$ & nd & nd & $d$ \\
\hline Carbon tetrachioride & 13.5 & 0.01 & nd & $d$ & nd & nd & d & nd \\
\hline Bromodichloromethane & 14.4 & 0.01 & nd & nd & $d$ & nd & d & nd \\
\hline $\left.\begin{array}{l}\text { 1,2-Dichloropropane } \\
\text { Trans-1,3-dichloropropene }\end{array}\right\}$ & 15.8 & 0.4 & nd & $0.90 \pm 0.41$ & $d(e)$ & $d(e)$ & $d(e)$ & $d(e)$ \\
\hline Trichloroethylene & 16.5 & 0.01 & $0.02 \pm 0.01(b)$ & $0.13 \pm 0.12$ & $0.02 \pm 0.01(b)$ & d & nd & $d$ \\
\hline $\begin{array}{l}\text { Dibromochloromethane } \\
\text { Cis-1.3-dichloropropene }\end{array}$ & 17.1 & 0.01 & nd & d & $0.03 \pm 0.03(b)$ & d & $d$ & nd \\
\hline Bromoform & 19.7 & 0.02 & nd & nd & d & nd & $d$ & $0.04(b)$ \\
\hline $\left.\begin{array}{l}\text { Tetrachloroethyl ene } \\
1,1,2,2 \text {-tetrachloroethane }\end{array}\right\}$ & 22.3 & 0.01 & $0.08 \pm 0.03$ & $0.13(a)$ & $0.09 \pm 0.09$ & $0.03 \pm 0.01$ & $0.04 \pm 0.03$ & $0.04 \pm 0.02$ \\
\hline
\end{tabular}
(a) Variance too high to compute standard deviation
(b) Not present in all subsamples
(c) $d=$ component present in trace quantities in some (but not all) subsamples
(d) nd $=$ not detected
(e) Detected at the minimum detectable level $(0.4 \mathrm{ng} / \mathrm{g})$ 


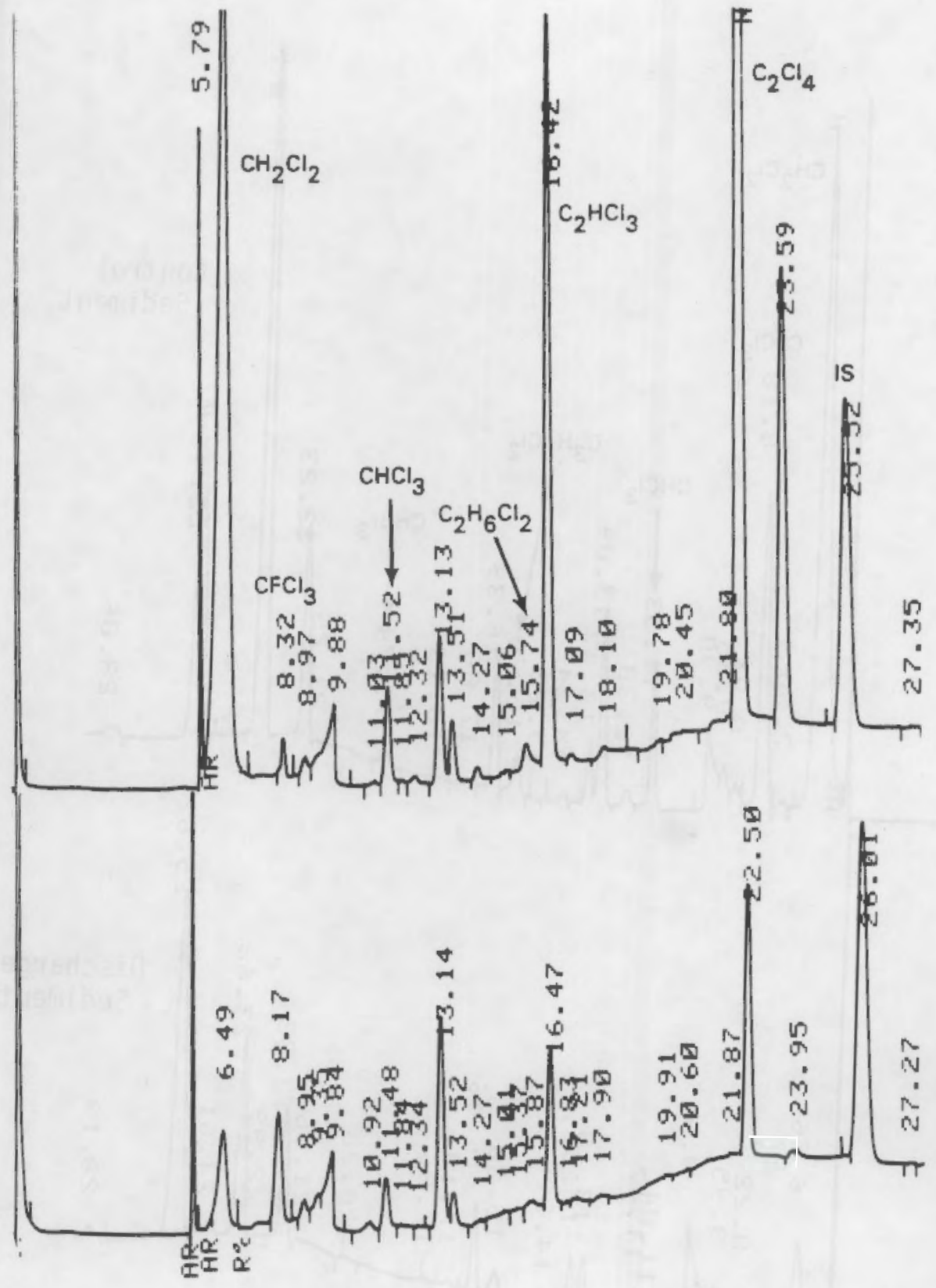

FIGURE 21. Electron Capture Purge-and-Trap Chromatograms of Beaver Valley Sediment Sampies. Top: Control Sediment; Bottom: Discharge Sediment. Peak at 23.59 is associated with sediment sample and is unidentified. 


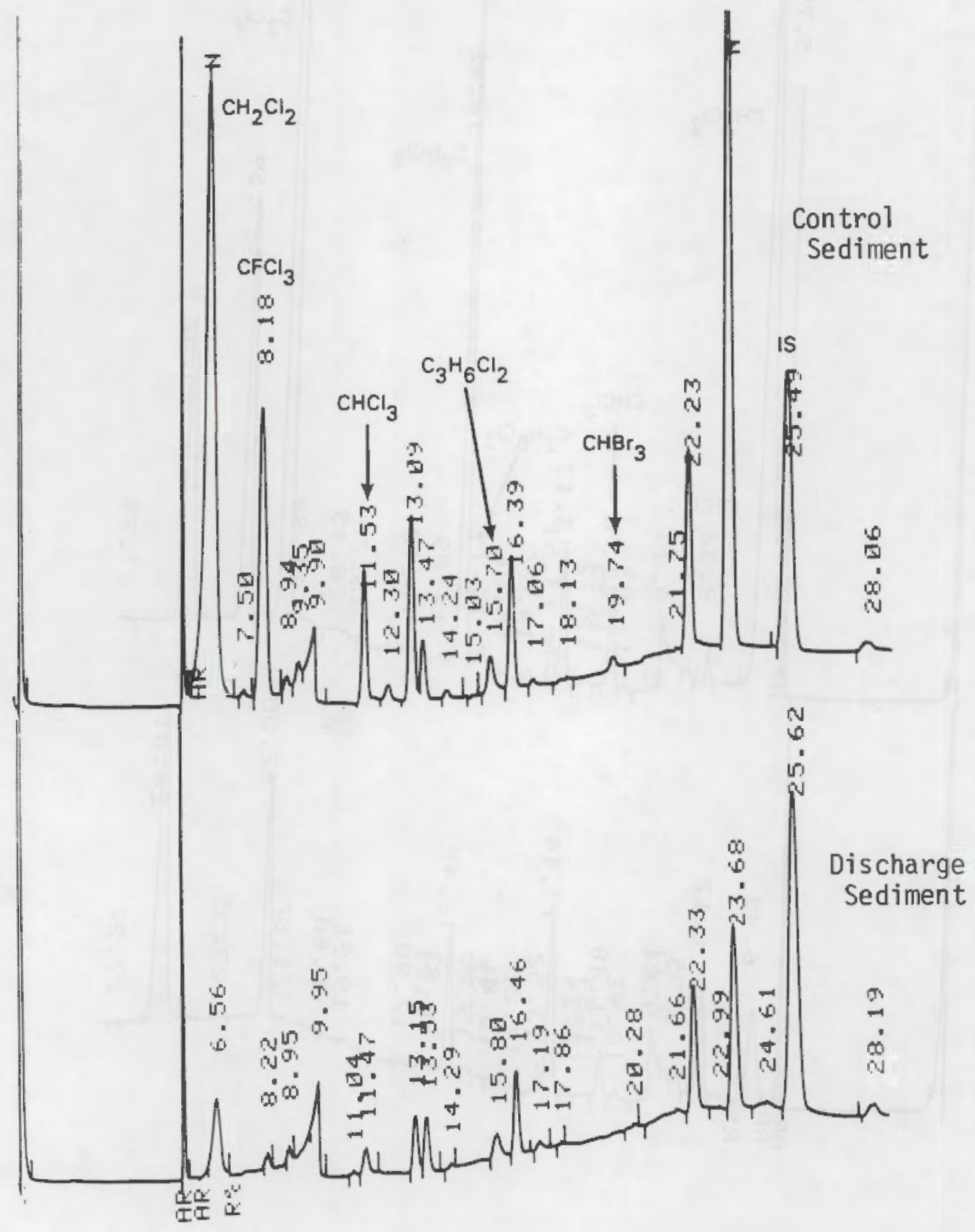

FIGURE 22. Electron Capture Purge-and-Trap Chromatograms of Trojan Sediment Samples. 


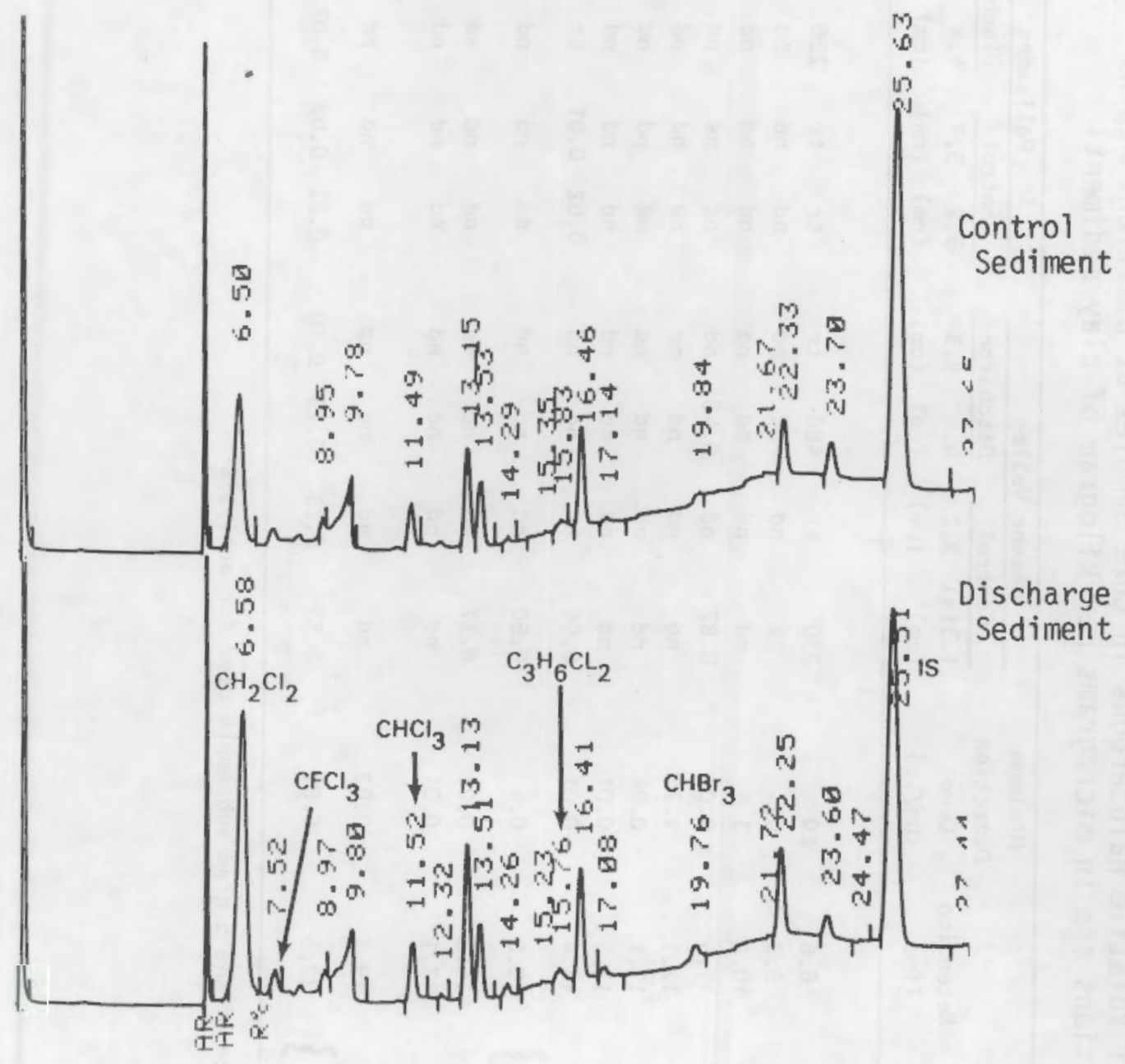

FIGURE 23. Electron Capture Purge-and-Trap Chromatograms of Pal isades Sediment Samples. 
TABLE 24. Analysis of Volatile Halocarbons in Core Samples at Different Depths (Concentrations are in micrograms per kilogram of clay sediment)

\begin{tabular}{|c|c|c|c|c|c|c|c|c|c|c|c|c|c|c|}
\hline \multirow[b]{3}{*}{ Component } & \multirow[b]{3}{*}{$\begin{array}{l}\text { Retention } \\
\text { Time }\end{array}$} & \multirow{3}{*}{$\begin{array}{c}\text { Minimum } \\
\text { Detection } \\
\text { Leve } \\
(\mu \mathrm{g} / \mathrm{kg})\end{array}$} & \multicolumn{4}{|c|}{ Beaver Valley } & \multicolumn{4}{|c|}{ Palisades } & \multicolumn{4}{|c|}{ Trojan } \\
\hline & & & \multicolumn{2}{|c|}{ Control } & \multicolumn{2}{|c|}{ Discharge } & \multicolumn{2}{|c|}{ Control } & \multicolumn{2}{|c|}{ Discharge } & \multicolumn{2}{|c|}{ Control } & \multicolumn{2}{|c|}{ Discharge } \\
\hline & & & $\begin{array}{l}1.3(\mathrm{a}) \\
(\mathrm{cm})\end{array}$ & $\begin{array}{l}3.2 \\
(\mathrm{~cm})\end{array}$ & $\begin{array}{l}4.4 \\
(\mathrm{~cm})\end{array}$ & $\begin{array}{l}8.3 \\
(\mathrm{~cm})\end{array}$ & $\begin{array}{l}3.2 \\
(\mathrm{~cm})\end{array}$ & $\begin{array}{l}5.7 \\
(\mathrm{~cm})\end{array}$ & $\begin{array}{l}4.4 \\
(\mathrm{~cm})\end{array}$ & $\begin{array}{l}7.0 \\
(\mathrm{~cm})\end{array}$ & $\begin{array}{l}7.0 \\
(\mathrm{~cm})\end{array}$ & $\begin{array}{l}10.8 \\
(\mathrm{~cm})\end{array}$ & $\begin{array}{l}7.6 \\
(\mathrm{~cm})\end{array}$ & $\begin{array}{l}11.4 \\
(\mathrm{~cm})\end{array}$ \\
\hline Methylene chloride & 6.6 & 20 & 230 & tr & 480 & tr & tr & tr & 290 & tr & 26 & tr & tr & $\operatorname{tr}$ \\
\hline Trichl or of luoromethane & 8.3 & 0.1 & nd & nd & nd & nd & nd & nd & nd & nd & nd & nd & nd & nd \\
\hline Trans $-1,2-d i$ chloroethylene & 10.8 & 3.4 & nd & nd & nd & nd & nd & nd & nd & nd & nd & nd & nd & nd \\
\hline Chloroform & 11.5 & 0.04 & 0.87 & nd & 0.46 & nd & nd & nd & nd & nd & 0.14 & 0.99 & nd & nd \\
\hline 1,2-Dichloroethane & 12.1 & 1.2 & nd & nd & nd & nd & nd & nd & nd & nd & nd & nd & nd & nd \\
\hline $1,1,1$-Trichloroethane & 13.1 & 0.04 & nd & nd & nd & nd & nd & nd & nd & nd & nd & nd & nd & nd \\
\hline Carbon tetrachloride & 13.5 & 0.01 & nd & nd & nd & nd & nd & nd & nd & nd & nd & nd & nd & nd \\
\hline Bromodichloromethane & 14.4 & 0.01 & 0.06 & $\operatorname{tr}$ & nd & nd & 0.02 & 0.01 & $\mathrm{tr}$ & 0.01 & 0.02 & 0.02 & 0.01 & 0.01 \\
\hline $\left.\begin{array}{l}\text { 1,2-Dichloropropane } \\
\text { Trans-1,3-dichloropropene }\end{array}\right\}$ & 15.8 & 0.4 & 0.50 & nd & nd & nd & nd & nd & nd & nd & nd & nd & nd & nd \\
\hline Trichloroethylene & 16.5 & 0.01 & 0.37 & nd & nd & nd & nd & nd & nd & nd & nd & nd & nd & nd \\
\hline Dibromachloromethane & 17.1 & 0.01 & nd & nd & nd & nd & nd & nd & nd & nd & nd & nd & nd & nd \\
\hline Cis-1,3-dichloropropene & & & & & & & & & & & & & & \\
\hline Bromoform & 19.7 & 0.02 & nd & nd & nd & nd & nd & nd & nd & nd & nd & nd & nd & nd \\
\hline $\begin{array}{l}\text { Tetrachloroethylene } \\
1,1,2,2-\text { Tetrachloroethane }\end{array}$ & 22.3 & 0.01 & 0.53 & 0.23 & 0.23 & 0.10 & 0.22 & 0.02 & 0.03 & 0.08 & 0.07 & nd & 0.01 & 0.01 \\
\hline
\end{tabular}

(a) Mean depth from surface of the 5 gram subsample used for analysis 


\subsection{Analysis of Sediments for Halogenated Phenols}

\subsubsection{Methods}

The procedure for soxhlet extraction of sediment samples has been in use in our laboratory for several years (Riley, et al., 1980). A preliminary wash of the wet sediment sample with methanol, followed by centrifugation, removes the water from the sediment sufficiently to allow good percolation of solvent through the sample. This preliminary step is not shown in the flow chart (Figure 24) for the extraction and separation of sediment organic material into acid and base-neutral fractions. Soxhlet extraction of $170 \mathrm{~g}$ sediment with $250 \mathrm{~mL}$ of an azeotrope of benzene-methanol was continued for $48 \mathrm{hr}$ or until the extracting solvent was colorless. For Beaver Valley samples, this took as long as a week, because the sample was high in organic carbon and very finely divided. The soxhlet extract was combined with the original methanol wash, and sufficient hexane added to form an organic layer and a methanol/water layer. The organic layer was washed with water to

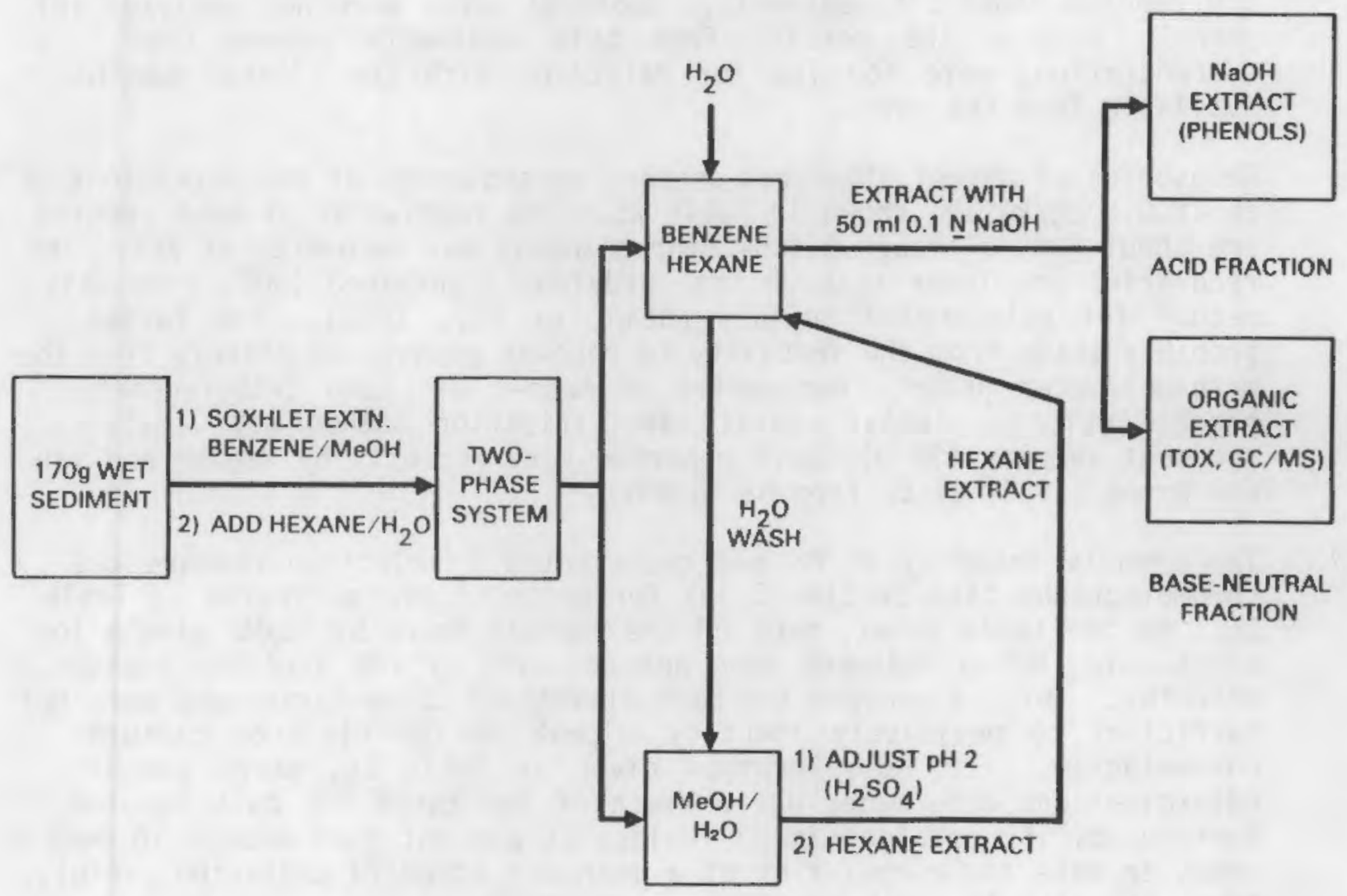

FIGURE 24. Flow Chart for Sediment Extraction and Separation into Acid (Phenol) and Base-Neutral Fractions 
remove methanol and the water wash was added to the methanol/water layer; the methanol/water layer was made acidic, extracted with hexane to remove any acidic material, and the hexane extract added to the organic layer. The organic layer was then extracted with $50 \mathrm{~mL}$ of 0.1 $\mathrm{NaOH}$ to remove the phenols, which were then derivitized with acetic anhydride and analyzed as described in Section 3.3.1. The organic layer was saved for analysis for base-neutrals and organic halogen by microcoulometry (Section 4.3). In order to investigate the sediment phenols by GC/MS, it was necessary to combine the extracts from about $500 \mathrm{~g}$ of sediment and evaporate the derivatized phenol fraction to $<200 \mu \mathrm{L}$ to obtain the concentrations required for mass spectral identification as discussed in Section 3.3.

\subsubsection{Results and Discussion}

Samples of bulk sediments taken from the vicinity of the discharge plumes were analyzed for halogenated phenols as described above and the results compared with sediments taken either upstream from the intake structure (Trojan and Beaver Valley), or in the case of Palisades, at a location 6.7 miles from the point of discharge. These latter samples are denoted "control" sediments. Sediment cores were not analyzed for phenols because the results from bulk sediments showed that concentrations were too low for detection with the limited sample available from the cores.

Recoveries of phenol standards amended to sediments at concentrations of about $0.5 \mu \mathrm{g} / \mathrm{kg}$ are shown in Table 25 . The recoveries of most species are about $40 \%$, al though 2,4,6-tribromophenol was recovered at $75 \%$. The recoveries are lower than we have previously obtained (50\%) from this method for halogenated phenols (Bean, et al., 1982). The losses probably arise from the inability to recover phenols completely from the methanol/water phase. Recoveries of mono-, di-, and trihalogenated phenols using a similar acetate derivitization method with smaller sediment samples $(30 \mathrm{~g})$, were reported very recently by Wegman and van den Broek (1983) to be from 62 to $89 \%$.

The phenols found by GC/MS and quantitated by electron capture gas chromotography (see Section 3.3.1 for methods) are presented in Table 26. As the table shows, many of the phenols found by GC/MS single ion scans using $500 \mathrm{~g}$ sediment were not detected by the electron capture detector. This is because the peak elevations above background were not sufficient to positively identify a peak in the electron capture chromatogram. For each location given in Table 26, three phenol determinations were made; one on each of the three $1 \mathrm{~L}$ bulk samples. Reproducability obtained among replicates was not good enough in most cases to make the computation of a mean and standard deviation useful, thus, the data for each replicate is recorded.

The occurrence in the Beaver Valley and Trojan sediment samples of trichlorophenol isomers other than 2,4,6-trichlorophenol is of interest. 
TABLE 25. Recovery of Phenols From Trojan Control Sediment

\begin{tabular}{lcc}
\hline \multicolumn{1}{c}{ Phenol } & $\begin{array}{c}\mu g \text { Amended to } \\
150 \mathrm{~g} \text { Wet Sediment }\end{array}$ & $\begin{array}{c}\text { Recovery } \pm \text { S.D. } \\
(\mathrm{n}=4)\end{array}$ \\
\hline p-Bromo & 0.860 & $30.8 \pm 9.3$ \\
2,5-Dichloro & 0.350 & $41.0 \pm 11.3$ \\
2,3-Dichloro & 0.535 & $38.6 \pm 9.4$ \\
3,4-Dichloro & 0.435 & $39.4 \pm 10.0$ \\
2-Bromo-4-Chioro & 0.545 & $43.8 \pm 12.5$ \\
2,3,6-Trichloro & 0.475 & $26.8 \pm 6.7$ \\
2,3,5-Trichloro & 0.640 & $46.0 \pm 11.2$ \\
2,6-Dibromo & 0.610 & $40.1 \pm 8.6$ \\
2,4,6-Tribromo & 0.490 & $74.3 \pm 14.9$ \\
\hline
\end{tabular}

TABLE 26. Analysis of Halogenated Phenols in Sediments Exposed to Power Plant Discharge Plume Versus Control Sediments (Concentrations in $\mu \mathrm{g} / \mathrm{kg}$ Dry Sediment)

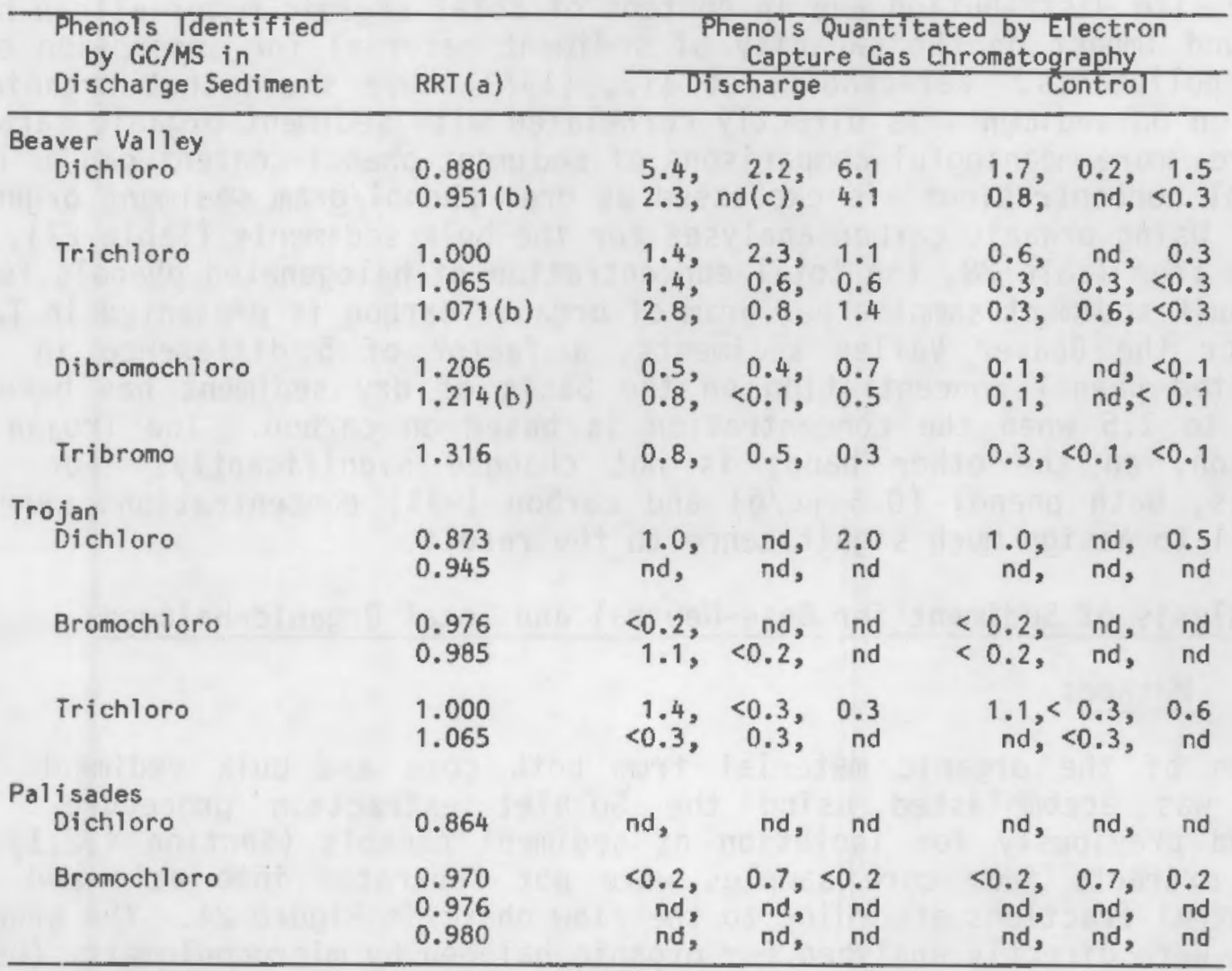

(a) Retention time relative to $2,4,6-t$ richlorophenol

(b) Peaks corresponding to these RRT's were found in the blank, and were subtracted from the analytical chromatograms

(c) $\mathrm{nd}=$ not detected 
We have not found any significant concentrations of trichlorophenol isomers other than 2,4,6-trichlorophenol to be formed during the chlorination of natural waters (Bean et al., 1980), or as a result of chlorination at any of the seven power stations we have examined. It appears likely that at least some of the halophenols we have found do not originate from power plant chlorination, or even other chlorination practices, but rather from industrial processes. Both Trojan and Beaver Valley stations are located near areas of heavy industrial activity. Wegman and van den Broek (1983) reported median concentrations of individual chlorinated phenols in sediments from industrialized areas of Europe that are in a similar concentration range $(0.2-6.3 \mu \mathrm{g} / \mathrm{kg})$ as the concentrations we found at the Trojan $(0.3-2.0 \mu \mathrm{g} / \mathrm{kg})$ and Beaver Valley $(0.2-5.4 \mu \mathrm{g} / \mathrm{kg})$ sites. These authors did not confirm the identities of the phenols they analyzed by mass spectrometry, nor did they analyze for brominated phenols.

Sediment concentrations of halogenated phenols were found to be higher in the discharge sediments than in controls for Beaver Valley and Trojan plants (Table 26). However, differences in sediment mineralogy, particle size distribution and in content of total organic material can have a profound impact on the capacity of sediment material for adsorption of organic pollutants. Karickhoff, et al., (1979) have shown that organic adsorption on sediments is directly correlated with sediment organic carbon. Therefore, more meaningful comparisons of sediment phenol content can be made if phenol concentrations are expressed as gram phenol/gram sediment organic carbon. Using organic carbon analyses for the bulk sediments (Table 27), and the data from Table 28 , the total concentration of halogenated phenols found in the bulk sediment samples per gram of organic carbon is presented in Table 4.6. For the Beaver Valley sediments, a factor of 5 difference in halogenated phenol concentration on the basis of dry sediment has been reduced to 1.5 when the concentration is based on carbon. The Trojan comparison, on the other hand, is not changed significantly. For Palisades, both phenol $(0.3 \mu \mathrm{g} / \mathrm{g})$ and carbon $(<1 \%)$ concentrations were too small to assign much significance to the result.

\subsection{Analysis of Sediment for Base-Neutral and Total Organic Halogen}

\subsubsection{Methods}

Isolation of the organic material from both core and bulk sediment samples was accomplished using the Soxhlet extraction procedure discussed previously for isolation of sediment phenols (Section 4.2.1). Organic extracts from core samples were not separated into acid and base-neutral fractions according to the flow chart in Figure 24. The organic extracts were directly analyzed for organic halogen by microcoulometry (Bean, et al., 1980). The bulk sediments were extracted and separated as described in Section 4.2.1, with the base-neutral fraction isolated for organic halogen analysis. Percent water in all sediment samples was determined using difference in weight between weight of wet sediment sample, and weight determined after Soxhlet extraction and over drying at $110^{\circ} \mathrm{C}$. Percent organic carbon in sediment cores and organic sulfur of extracts were 
TABLE 27. Sediment Characteristics at Beaver Valley, Trojan, Palisades

\begin{tabular}{lcrrrr}
\hline Sample & Sand & Silt & Clay & $\% \mathrm{H}_{2} \mathrm{O}(\mathrm{n}=2)$ & $\begin{array}{c}\text { \% Organic Carbon } \\
\text { (dry basis) }\end{array}$ \\
\hline $\begin{array}{l}\text { Beaver Valley } \\
\text { Discharge }\end{array}$ & 32 & 56 & 12 & $49.3 \pm 0.0$ & 9.9 \\
$\quad$ Control & 93 & 4 & 3 & $18.7 \pm 0.7$ & 3.5 \\
$\begin{array}{l}\text { Trojan } \\
\text { Discharge }\end{array}$ & 77 & 18 & 5 & $15.9 \pm 0.0$ & 1.7 \\
Control & 81 & 14 & 5 & $16.1 \pm 0.0$ & 1.6 \\
$\begin{array}{l}\text { Palisades } \\
\text { Oischarge }\end{array}$ & 99 & 1 & 0 & $32.3 \pm 0.2$ & 0.51 \\
Control & 99 & 0 & 1 & $30.7 \pm 0.9$ & 0.18 \\
\hline
\end{tabular}

TABLE 28. Total Halophenol Concentrations in Sediment Samples From Beaver Valley, Trojan and Palisades

\begin{tabular}{lcc}
\hline Location & $\begin{array}{c}\text { Halogenated Phenols } \\
\text { in Sediments } \\
(\mu \mathrm{g} / \mathrm{kg} \text { dry sed.) }\end{array}$ & $\begin{array}{c}\text { Halogenated Phenols } \\
\text { per Gram Organic C } \\
(\mu \mathrm{g} / \mathrm{g})\end{array}$ \\
\hline $\begin{array}{l}\text { Beaver Valley } \\
\quad \text { Control }\end{array}$ & & \\
$\quad$ Discharge & 2.7 & 0.08 \\
$\quad \begin{array}{l}\text { Trojan } \\
\text { Control }\end{array}$ & 12.3 & 0.12 \\
$\quad$ Discharge & 1.1 & 0.07 \\
Palisades & 2.1 & 0.12 \\
$\quad$ Control & & \\
Discharge & 0.3 & 0.06 \\
\hline
\end{tabular}


determined by Schwarzhopf Analytical Laboratories. Particle size distribution and percent organic carbon of bulk sediments were determined by Camp Dresser and McKee, Inc.

\subsubsection{Resuits and Discussion}

The results obtained from the first three stations visited (Duane Arnold, Millstone and Arkansas) were from the top $2 \mathrm{~cm}$ of replicate core samples (Table 29). On two difference occasions, solvent evaporated from the soxhlet apparatus during the night, and the sample was lost. Thus, the results of the organic halogen analyses reported in Table 29 are based on both duplicate and triplicate samples.

A yellow precipitate, suspected to be elemental sulfur, was found in the final concentrates of all the samples taken from Millstone. The Millstone samples contained very high concentrations of organic halogen (Table 27). Sulfur interferes with the organic halogen analys is if in large excess over halogen, therefore, one portion of the control and discharge concentrates were analyzed for sulfur and the other portion was chromatographed over silica gel using $20 \%$ ether in hexane (see Section 3.4.1). The results showed that the samples did contain high concentrations of sulfur, which, when remved by adsorption on silica gel, resulted in much lower numbers for organic chlorine. Concentrated samples from Arnold and Arkansas did not contain a sulfur precipitate.

The results of the initial studies performed on the core samples from Arnold, Millstone, and Arkansas, indicated that a higher concentration of organic halogen was present in the discharge sediments than in the control sediments. This is also the case when the data are based on organic carbon content. This result is complicated by the high variability obtained among replicates, and by the presence of elementa? sulfur in samples obtained from at least one power plant location. The identity of the halogenated material was not explored by GC/MS because the quantity of organic halogen as measured by microcoulometry was too low.

There was sufficient sample in the bulk sediments taken from Beaver Valley, Trojan, and Palisades to characterize the sediments by sand, silt, and clay content, as well as to determine the percent organic carbon. These data are presented in Table 27. Sediments at control and discharge locations were similar for the Trojan and Palisades samples; however, the Beaver Valley discharge sediments contained significantly more fine mineral, organic carbon, and water than did the control sediment. The Beaver Valley control also contained small pebbles that were not found in the discharge sample. 
TABLE 29A. Organic Halogen Content of Sediments From Duane Arnold and Millstone

\begin{tabular}{|c|c|c|c|c|c|}
\hline Location & i $\mathrm{H}_{2} \mathrm{O}$ & $\begin{array}{l}\text { Organic C } \\
\text { (dry basis) (b) }\end{array}$ & $\begin{array}{l}\text { Organic H } \\
\text { "g CT/g Dry } \\
\text { Sediment }\end{array}$ & $\begin{array}{l}\text { IIgen } \\
\text { org. C(b) }\end{array}$ & $\begin{array}{l}\text { SuTfur Found in Organic } \\
\text { Extract } 11 \mathrm{~g} / \mathrm{g} \\
\text { Dry Sediment(c) }\end{array}$ \\
\hline \multicolumn{6}{|l|}{ Duane Arnold (a) } \\
\hline $\begin{array}{l}\text { Intake } \\
\text { (sand, gravel, mud) }\end{array}$ & $22.4 \pm 1.5$ & 0.43 & $0.06 \pm 0.05$ & 2 & \\
\hline $\begin{array}{l}\text { Discharge } \\
\text { (fine sand, mud) }\end{array}$ & $18.1 \pm 5.9$ & 0.41 & $0.29 \pm 0.1$ & 39 & \\
\hline $\begin{array}{l}\text { River Plume } \\
\text { (black mud) }\end{array}$ & $33.8 \pm 9.0$ & 1.05 & $0.31 \pm 0.10$ & 28 & \\
\hline \multicolumn{6}{|l|}{ Millstone (d) } \\
\hline $\begin{array}{l}\text { Intake } \\
\text { (shells, black mud) }\end{array}$ & $25.1 \pm 1.9$ & 0.28 & $\begin{aligned} 2.21 & \pm 0.65 \\
(0.03 & \pm 0.02)(e)\end{aligned}$ & $\begin{array}{l}560 \\
(18)\end{array}$ & $540 \pm 26$ \\
\hline $\begin{array}{l}\text { Discharge } \\
\text { (gravel, mud, wood clips) }\end{array}$ & $7.0 \pm 0.7$ & 0.41 & $\begin{array}{c}0.52 \pm 0.17 \\
(0.11 \pm 0.01)\end{array}$ & $\begin{array}{c}83 \\
(26)\end{array}$ & $230 \pm 140$ \\
\hline $\begin{array}{l}\text { Plume } \\
\text { (black mud) }\end{array}$ & $23.7 \pm 0.8$ & 0.57 & $1.03 \pm 0.5$ & 120 & $45 \pm 2$ \\
\hline
\end{tabular}
(a) $8 \mathrm{H}_{2} \mathrm{O}$ and $\mu \mathrm{g} \mathrm{Cl} / \mathrm{g}$ dry sediment are averages of 3 cores \pm s.d. for all Duane Arnold samples
(b) Organic $\mathrm{C}$ and $1 \mathrm{~g} \mathrm{Cl} / \mathrm{g} \mathrm{C}$ determined for only 1 core sample at each sampling location
(c) Sulfur determinations obtained for Millstone samples only
(d) $\mathrm{H}_{2} \mathrm{O}$ and $\mu \mathrm{g} \mathrm{Cl} / \mathrm{g}$ dry sediment are averages of 2 cores \pm standard error with exception of intake, where $n=3$ where $n=3$
(e) Data in parentheses were obtained after chromatography of organic extract over silica gel

TABLE 29B. Organic Halogen Content of Sediments from Arkansas

\begin{tabular}{|c|c|c|c|c|c|c|}
\hline \multirow[b]{2}{*}{ Location } & \multirow[b]{2}{*}{$\mathrm{H}_{2} \mathrm{O}$} & \multirow[b]{2}{*}{ Organic C } & \multicolumn{2}{|c|}{ Organic Halogen } & \multicolumn{2}{|c|}{$\begin{array}{l}\text { \% Organic Halogen in } \\
\text { Silica Cel Fractions } \\
\end{array}$} \\
\hline & & & $\begin{array}{l}\mu \mathrm{g} C 1 / \mathrm{g} \text { Dry } \\
\text { Sediment }\end{array}$ & $\underset{\text { organic } \mathrm{Cl}}{\mathrm{hg} / \mathrm{g}}$ & (20\% Ether) & (1008 Ether) \\
\hline Arkansas & & & & & & \\
\hline $\begin{array}{l}\text { Intake (a) } \\
\text { (hard clay) }\end{array}$ & $28.6 \pm 4.5$ & $0.76 \pm 0.12$ & $0.05 \pm 0.04$ & $3 \pm 2$ & $75 \pm 25$ & $25 \pm 25$ \\
\hline $\begin{array}{l}\text { Tower(a) } \\
\text { (fine silt) }\end{array}$ & $51.6 \pm 5.7$ & $2.02 \pm 0.12$ & $2.1 \pm 0.8$ & $99 \pm 36$ & $92 \pm 2$ & $8 \pm 2$ \\
\hline $\begin{array}{l}\text { Discharge } \\
\text { (hard clay) }\end{array}$ & $28.1 \pm 2.6(b)$ & $0.26 \pm 0.09(b)$ & $0.35(0.05-0.86)(\mathrm{c})$ & $124(29-307)(\mathrm{c})$ & $98(94-100)(c)$ & $2(0-6)(c)$ \\
\hline
\end{tabular}

(a) $n=2$ for both intake and tower samples. Values are mean \pm range standard error

(b) $n=3$. Values are mean $\pm s . d$.

(c) $n=3$. Values are means. Range given in parentheses 
Results of the organic halogen analyses from Beaver Valley, Trojan, and Palisades are given in Table 30 . Large differences in organic halogen content between Beaver Valley control and discharge sediments can partly be explained by the large differences in bulk sediment properties. When the results are based on the organic carbon content, differences between discharge and control sediments are reduced from a factor of 5 to a factor of 2. As was found in the case of the earlier core samples, all discharge samples were found to contain more organic halogen than control samples, whether based on dry sediment or organic carbon.

The results of silica gel chromatrography of Arkansas, Beaver Valley, Trojan, and Palisades sediments (Tables 29 and 30 ) indicate that the majority of the organohalogen material is relatively nonpolar. The combined base-neutral fractions from three replicate Soxhlet extractions from Beaver Valley, Trojan, and Palisades were examined by GC/MS using the procedures described for XAD water samples (Section 3.4.1). An examination of the major peaks in the chromatograms obtained did not reveal any halogenated compounds that were not also found in the control sediments. Of 242 chromatographic peaks examined, only 5 produced spectra indicative of possible halogenated compounds (Trojan, 4; Palisades, 1). Electron capture chromatograms of all three discharge samples were obtained. No electron capturing (potentially halogenated) peaks were obtained from Trojan or Palisades samples. However, a pattern of peaks was apparent in the chromatograms from Beaver Valley discharge sediment samples that indicated the presence of polychlorinated biphenyls (PCB's). These components were confirmed to be present

TABLE 30. Total Organic Halogen in Sediments

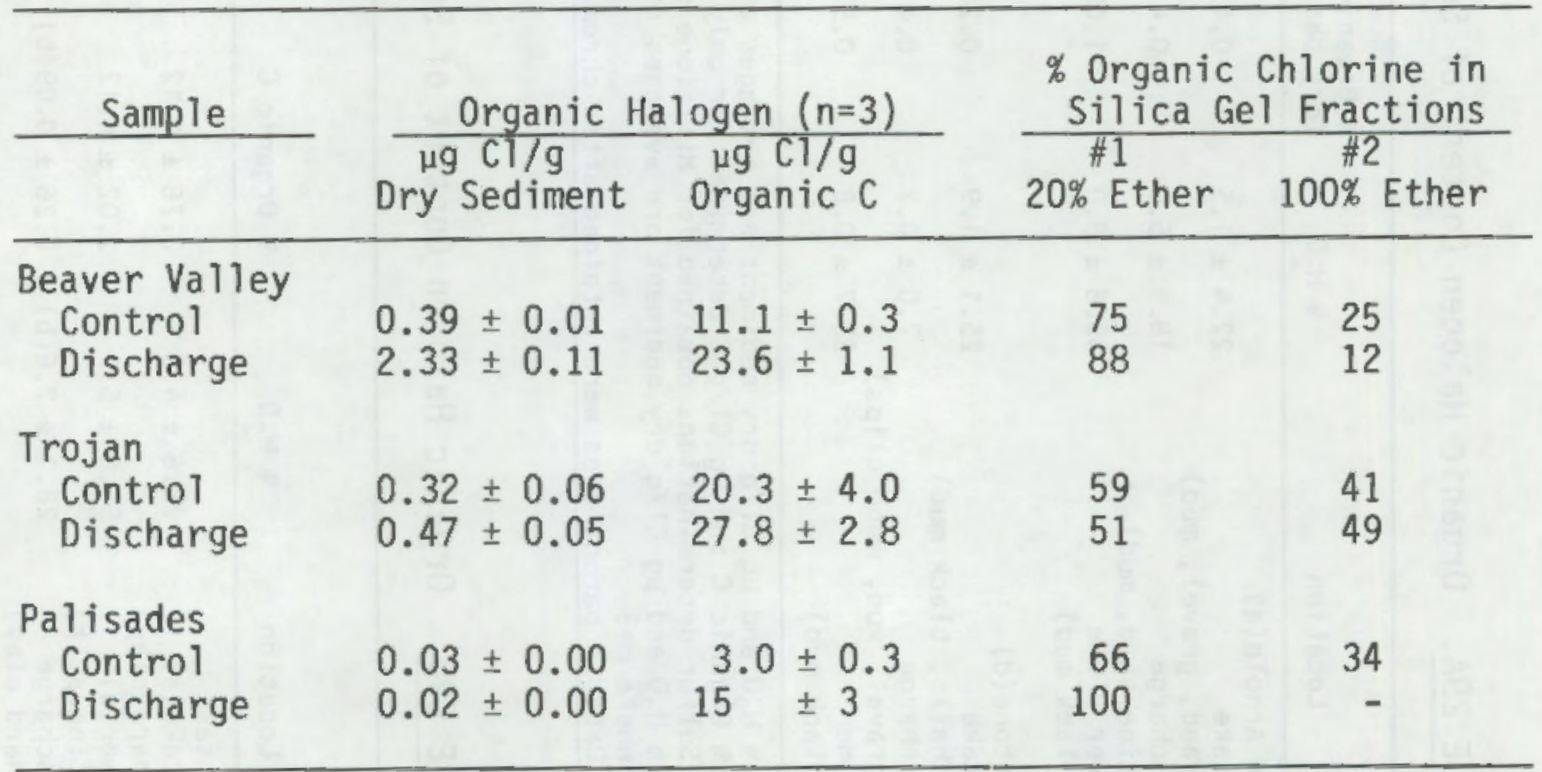


by examining the single ion scans corresponding to the molecular weights for several PCB components. Scans obtained are shown in Figure 25. Because the number of PCB components is large in a commercial PCB blend, it is not surprising that individual $P C B$ peaks did not show up in the total ionization chromatogram. Electron capture analys is found 2.4 , 0.6 , and $3.8 \mathrm{mg} / \mathrm{kg}$ (parts-per-million) of PCB in the three bulk samples examined.

The chromatographic pattern obtained is suggestive of Arocior 1260 . Aroclors are produced by high temperature chlorination procedures and would not be expected as a product of power plant chlorination. Aroclors have been widely used as insulating fluid in electrical transformers, a likely source for the PCB's we have found. The origin of the PCB's found cannot be determined with certainty, because the Beaver Valley plant at present has no inventory of PCB. The deposits could have come during plant construction, or startup, or may have come from another source in this area because the Beaver valley plant is down river from other power plants and heavy industry.

NHTE BEAYER YALLEY DISCHARGE ORGAHICS 2/2/83 SEDIMENT; THOMAS MIISC RD3 THE HV2000 M126-580 SP21BO SOH 3.5UL

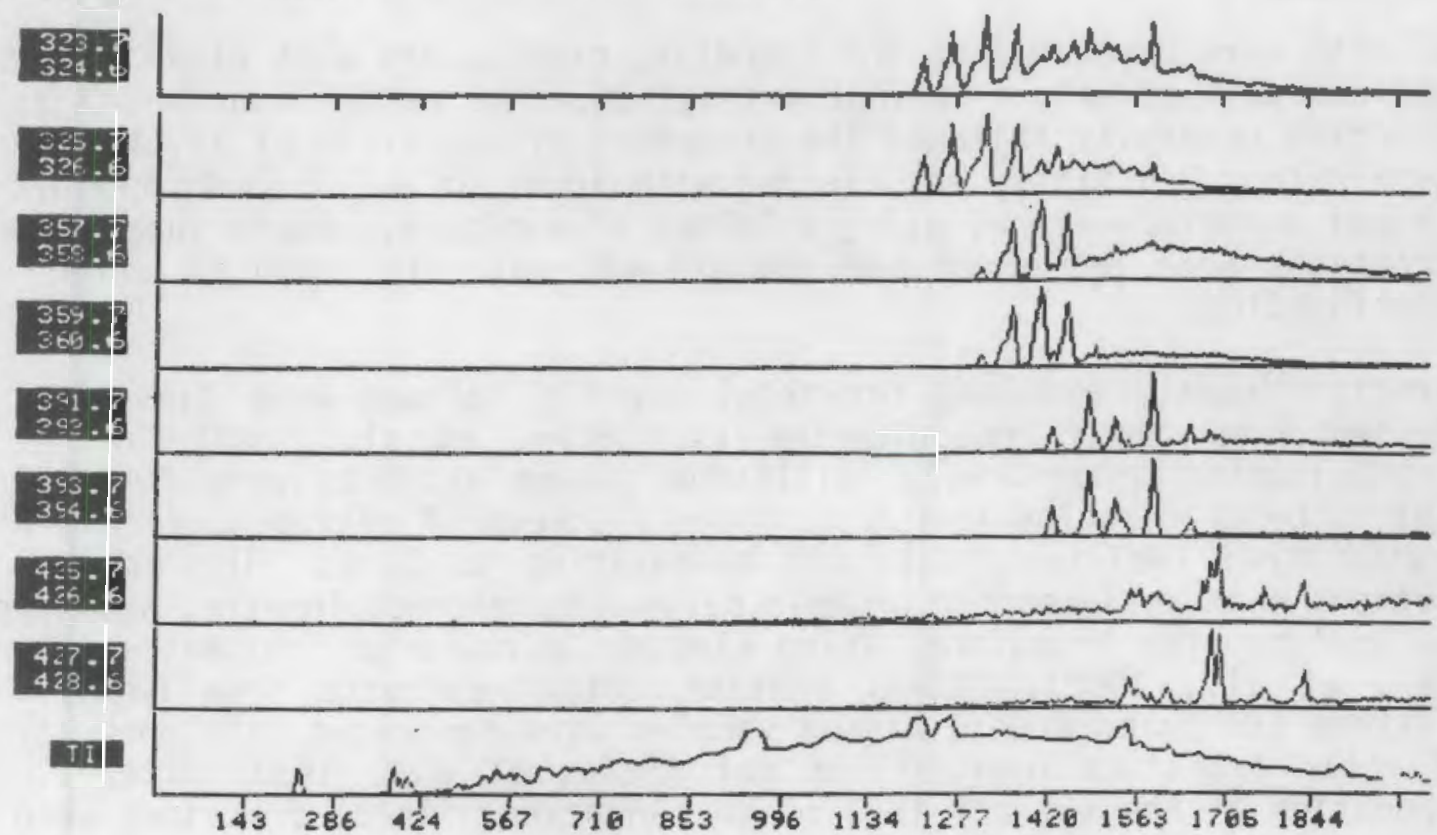

FIGURE 25. Single Ion Chromatograms Obtained From Chlorinated PCB's in Beaver Valley Discharge Sediment. $M=324,392$ and 426 Correspond to Biphenyls Substituted with $5,6,7$ and 8 Chlorines 


\subsection{ANALYSIS OF SHELLFISH FOR HALOFORM AND ORGANIC HALOGEN}

Previous studies of the effects of chloroform on freshwater fish (Anderson and Lusty, 1980) and of bromoform on marine shellfish (Gibson, et a1., 1980b) have demonstrated the potential for bio-uptake of these chlorination products. Although bio-uptake upon exposure was shown by these authors to be fairly rapid, the depuration of these materials from experimental animals upon termination of exposure was also rapid. During the sampling trips to Duane Arnold, Millstone, and Arkansas power stations, a part of the sampling effort was devoted to collection of sedentary organisms from the sediments of the cooling water discharge. These samples were to be used to determine whether the bio-uptake observed in the laboratory could be confirmed for organisms exposed to chlorinated power plant discharges. The results of the collection efforts were disappointing in that of the three sites visited, suitable organisms were found at only the Millstone plant. The samples collected, Mytilus edulis, were analyzed for total organic halogen by microcoulometry, and for bromoform content by electron capture gas chromatography. Samples of fingernail clams, Sphaerium transversum, were found in the sediment of the discharge canal at Duane Arnold, but no animals of the same species could be located in the Cedar River, either in the discharge plume or at selected control sites. Even though no suitable control animals could be located, the freshwater clams were analyzed for organic halogen and chloroform.

\subsection{Methods}

Shellfish were removed from their shells, blotted dry with clean tissue paper and weighed before solvent extraction. The method used for tissue extraction generally followed the procedure of Augenfeld et al. (1982). Approximately $5 \mathrm{~g}$ tissue was blended with $10 \mathrm{~mL}$ of a $2: 1$ ( $\mathrm{V}: \mathrm{V})$ mixture of ethyl acetate/acetone, using a Tekmar Tissumizer@. Three successive extractions were performed and the solvent extracts combined after centrifugation.

Extracts directly examined for total organic halogen were directly injected into the microcoulometer (see Bean, et a1., 1980 for microcoulometer procedures). Millstone tissue extracts were further examined by evaporating to $0.5 \mathrm{~mL}$ under a stream of nitrogen, adding 10 $\mathrm{mL}$ ethylether (Mallinckrodt), and evaporating to $3 \mathrm{~mL}$. The ether solutions were analyzed for organic halogen by microcoulometry, and were also analyzed for bromoform, using electron capture gas chromatography (Bean, et al., 1980). Ethyl acetate/acetone extracts from both Millstone and Duane Arnold tissue samples were separated into nonpolar and polar fractions over silica gel (Bean, et al., 1980) after evaporation of the extract to $1 \mathrm{~mL}$ in $n$-heptane. These fractions were also analyzed for total organic halogen.

Clam tissue from the Arnold plant was analyzed for chloroform by direct extraction of $1 \mathrm{~g}$ tissue with $3 \mathrm{~mL}$ ethel ether, centrifuging, and analyzing the extract for chloroform using electron capture gas chromatography. 


\subsection{Results and Discussion}

Bromoform was not found in any of the Millstone tissue samples analyzed. The sensitivity of the method was determined to be $0.02 \mathrm{ng} / \mathrm{g}(\mathrm{ppb})$ from a $5 \mathrm{~g}$ tissue sample. Recovery of added bromoform from a sample spiked with $3 \mathrm{ng}$ of bromoform was $83 \%$. The Millstone cooling water discharge was found to contain about $4 \mu \mathrm{g} / \mathrm{L}$ bromoform (Section 3.2). Concentrations of bromoform at the tissue sample point were not measured, but were probably between 1 and $4 \mu \mathrm{g} / \mathrm{L}$. Bio-uptake of bromoform by the mussels to the level of the water concentration would have been easily detected by our analytical procedure. On the other hand, our failure to detect chloroform in the fingernail clam tissue was not surprising, because the determined limit of detection were $15 \mathrm{ng} / \mathrm{g}$ and the levels of chloroform in the discharge have been found to be about $0.5 \mu \mathrm{g} / \mathrm{L}$ (Section 3.2). Thus, the bioaccumulation factor would have had to be on the order of 30 in order for us to detect traces of chloroform in these samples.

The results from the total organic halogen measurements are given in Table 31. The initial results with the ethyl acetate/acetone extracts of Millstone samples gave very high values for organic halogen, and if all was organic halogen, indicated bioconcentration factors of 1000 . An experiment was conducted in which sodium chloride was added to the sample during homogenization. The result (Table 31) indicated that organic chloride (present in all tissue) could interfere with the results. Attempts to remove mineral chloride by evaporation and changing solvent did not appear to decrease the apparent organic chlorine concentration significantly. Silica gel chromatography removed about $90 \%$ of the material giving a microcoulometric response, but did indicate that at least part of the material was nonpolar organic material when about $1 \mu \mathrm{g} / \mathrm{g}$ halogen was found in the $20 \%$ ether-80\% hexane eluate. A comparison of exposed tissue samples with controls indicates, however, that the organic chlorine measured has little to do with the halogen compounds found in the chlorinated power plant effluent stream, because control concentrations do not differ from exposed concentrations.

TABLE 31. Organohalogen in Tissue Samples

(Values Given as $\mu \mathrm{g} / \mathrm{g}$ Wet Tissue)

\begin{tabular}{|c|c|c|c|c|c|}
\hline \multirow[b]{2}{*}{ Location } & \multirow{2}{*}{$\begin{array}{l}30 \mathrm{~mL} \text { Ethy } 1 \text { Acetate/ } \\
\text { Acetone Extract }\end{array}$} & \multirow{2}{*}{$\begin{array}{l}\text { Add Ether, } \\
\text { Evap. to } 3 \mathrm{~mL}\end{array}$} & \multicolumn{3}{|c|}{ Silica Gel Fractions } \\
\hline & & & $\# 1-208$ & Ether & \#2-1008 Ether \\
\hline $\begin{array}{l}\text { Mill lstone } \\
\text { Intake } \\
\text { Discharge } \\
\text { Effluent } \mathrm{Plume} \\
\text { Disch. + } \mathrm{NaCl}(\mathrm{a})\end{array}$ & $\begin{array}{r}9.5 \pm 3.1 \\
16.5 \pm 6.3 \\
17.1 \pm 6.4 \\
24.4 \pm 7.4\end{array}$ & $\begin{array}{c}11.2 \pm 5.3 \\
11.5 \pm 5.2 \\
11.9 \pm 3.9 \\
-\end{array}$ & $\begin{array}{l}1.1 \\
1.0 \\
1.0\end{array}$ & $\begin{array}{l} \pm 0.1 \\
\pm 0.3 \\
\pm 0.0 \\
-\end{array}$ & $\begin{array}{ll}0.3 & \pm 0.1 \\
0.06 & \pm 0.06 \\
0.1 & \pm 0.1 \\
& =\end{array}$ \\
\hline $\begin{array}{c}\text { Duane Arnold } \\
\text { Discharge }\end{array}$ & - & - & 0.2 & \pm 0.1 & Not detected \\
\hline
\end{tabular}




\section{CONCLUSIONS}

- For each of the eight nuclear units studied, less than one percent of the chlorine added to cooling water as a biocide is converted to volatile or lipophilic organohalogen material. This finding is in agreement with our previous studies of the chlorination of ten natural water bodies across the U.S. (Bean et al., 1980).

0 The concentrations of total organic halogen discharged were found to be in the range of 2 to $4 \mu \mathrm{g} / \mathrm{L}$ (parts per billion) chlorine. (The Palisades plant sample was analyzed for $5.5 \mu \mathrm{g} / \mathrm{L}$ but the sample was taken before dilution was complete). The concentrations of haloforms discharged were several orders of magnitude lower than LD50's determined for a variety of aquatic animals in a previous study (Bean et al., 1981).

- Cooling tower discharges can contain halogenated phenols in concentrations much greater than once-through discharges, because of the concentrating action of the towers. The highest concentration of total halogenated phenols in tower blowdown was $4.3 \mu \mathrm{g} / \mathrm{L}$ (Trojan), which is in the same concentration range as the principle organohalogen products, the haloforms. Mitigating any adverse consequences of these higher phenol concentrations are the much lower water discharge volumes of cooling towers.

- Haloform production for all freshwater plants was calculated to be less than 200 grams per chlorination day. Halogenated phenol production for those same plants was less than 100 grams per chlorination day.

- Concentrations discharged from the one marine-cooled nuclear plant studied (Millstone) were comparable to those found at a fossil fuel fired plant on the California Coast (Bean et al., 1982). Total discharge per chlorination day of haloforms were calculated to be higher than for the fresh water plants $(5.8 \mathrm{~kg}$ haloforms, $0.7 \mathrm{~kg}$ halogenated phenols) principally because of higher chlorine usage.

- Cooling towers discharge much of the haloforms formed from chlorination directly to the atmosphere through evaporation and drift. The quantities discharged to atmosphere are estimated to be less than one kilogram per tower per chlorination cycle. 
- Analysis of sediments in the vicinity of power plants for total organic halogen and possibly for halogenated phenols, may be useful means for defining the extent of chlorinated organic discharge plumes receiving waters, because concentrations of TOX and halophenols were found to be higher in discharge sediments than in controls. Haloforms from power plant discharges were not found to accumulate in sediments.

- No halogenated material was found to be bioaccumulated in mussels exposed to the chlorinated discharge of a marine power station (Millstone). 


\section{RECOMMENDATIONS}

- These studies indicate that present effluent guidelines (EPA, 1982) promulgated by the Environmental Protection Agency $(0.2 \mathrm{mg} / \mathrm{L}$ total residual chlorine and $2 \mathrm{hr} /$ day/unit maximum chlorination time) will not result in production of volatile or lipophilic halogenated materials substantially above those concentrations found in this study. An exception to this is if a power plant elects to dechlorinate with chemical reducing agents in order to meet the effluent guidelines. If very high chlorine levels are used, and then treated with reducing agents to meet the $0.2 \mathrm{mg} / \mathrm{L}$ guideline, unacceptably high discharges of halogenated organics may result. Thus, plants using dechlorination should monitor their discharges for organohalogen materials, particularly haloforms and halogenated phenols.

- Halogenated phenols, produced in significant quantities in chlorinated power plant cooling towers, should be further investigated for their environmental and toxicological properties. Little is known about the toxicity or potential for bioaccumulation of brominated phenols, or bromochlorophenols. We have found these compounds in concentrations of milligrams per gram organic carbon in sediments, which represents a significant environmental concentration. At present, it is not possible to determine the environmental impact from discharges of halophenols without more data on their physical and toxicological properties.

- One of the problems of measuring the environmental impacts of chlorinated power plant discharges is the difficulty in defining the regional extent of the chlorinated plume. Animal population surveys, and other biological data are difficult to correlate with the point source of chlorinated discharge if the extent of the effective distribution of chloroorganics is not known. Our analyses of sediments for halogenated phenols and for total organic halogen have indicated a positive correlation with exposure to effluent plume. A systematic study of organohalogen concentrations in sediments as a function of distance from a specific power plant discharge is recommended, to determine if such a correlation can be confirmed. If such were the case, appropriate biology studies could be conducted to determine whether chlorinated discharges significantly influence the environment outside the confines of the thermal plume. 
- Additional sampling and analytical studies of power plants should be conducted to include extensive sampling of chlorinated cooling tower atmosphere. The studies reported here relate almost exclusively to aquatic discharges. Although some data is available on release to atmosphere of chloroform, the types and amounts of halogenated materials released through both evaporation and drift is still largely unexplored. Although such a program would require substantial effort and method development, a comprehensive evaluation of the effect of power plant chlorination on the environment is not complete without this additional information. Such a study should also include research on the atmospheric chemistry of those halogenated products found to be present in significant concentrations in the atmosphere discharges. 



\subsection{REFERENCES}

Anderson, D. R., R. M. Bean and R. E. Schirmer. 1980. Chronic effects of chlorination by-products on Rainbow trout, Salmo gairdneri. NUREG/CR-0892. Prepared by Battelle, Pacific Northwest Laboratory, for the U.S. Nuclear Regulatory Commission.

Anderson, D. R., and E. W. Lusty. 1980. Acute toxicity and bioaccumulation of chloroform to four species of fresh water fish. NUREG/CR-0893. Prepared by Battelle, Pacific Northwest Laboratory, for the U.S. Nuclear Regulatory Commission.

Augenfeld, J. M., J. W. Anderson, R. G. Riley and B. L. Thomas. 1982. The fate of polyaromatic hydrocarbons in an intertidal sediment exposure system: Bioavailability to Macoma inquinata and Abarenicola pacifica. Marine Environ. Poll. 7:31-50.

Bean, R. M., D. C. Mann and R. G. Riley. 1980. Analysis of organohalogen products from chlorination of natural waters under simulated biofouling control conditions. NUREG/CR-1301. Prepared by Battelle, Pacific Northwest Laboratory, for the U.S. Nuclear Regulatory Commission.

Bean, R. M., D. C. Mann and D. A. Neitzel. 1983. Organohalogens in chlorinated cooling waters discharged from nuclear power stations. In: Water Chlorination: Environmental Impact and Health Effects. Vol. 4., R. L. Jolley, (ed.) Ann Arbor Science, Ann Arbor, MI, pp. 383-390.

Bean, R. M., R. G. Riley and P. W. Ryan. 1978. Investigation of halogenated components formed from chlorination of marine water. In: Water Chlorination: Environmental Impact and Health Effects. R. L. Jolley, H. Gorchev and D. H. Hamilton, Jr., (ed.). Ann Arbor Science, Ann Arbor, MI. pp. 223-234.

Bean, R. M., D. C. Mann and R. G. Riley. 1980. Analysis of organohalogen products from chlorination of natural waters under simulated biofouling control conditions. NUREG/CR-1301. Prepared by Battelle, Pacific Northwest Laboratory, for the U.S. Nuclear Regulatory Commission.

Bean, R. M., C. I. Gibson and D. R. Anderson. 1981. Biocide by-products in aquatic environments: Final Report, Sept. 10, 1976 - Sept. 30, 1979. NUREG/CR-1300. Prepared by Battelle, Pacific Northwest Laboratory, for the U.S. Nuclear Regulatory Commission.

Bean, R. M., and R. G. Riley. 1980. Investigation of halogenated components formed from chlorination of natural waters: Preliminary studies. NUREG/CR-1299. Prepared by Battelle, Pacific Northwest Laboratory, for the U.S. Nuclear Regulatory Commission. 
Bean, R. M., R. L. Wilson, D. A. Neitzel and M. A. D'Malley. 1982. Analysis of organohalogen and other organic chemicals in cooling waters discharged from Redondo Generating Station. Battelle, Pacific Northwest Laboratory, Richland, WA 99352.

Bellar, T. A., and J. J. Lichtenberg. 1974. Determining volatile organics at microgram-per-liter levels by gas chromatography. J. Am. Water Works Assoc. 66:739-744.

Bouwer, E. J., B. E. Rittmann and P. L. McCarty. 1981. Anaerobic degradation of halogenated 1- and 2-carbon organic compounds. Environ. Science and Technol. 15:596-599.

Carlson, R. M., R. E. Carlson, H. L. Kopperman and R. Caple. 1975. Facile incorporation of chlorine into aromatic systems during aqueous chlorination processes. Env. Sci. and Tech. 9:674-675.

Carpenter, J. H., and C. A. Smith. 1978. Reactions in chlorinated seawater. pp. 195-208. In: Water Chlorination - Environmental Impact and Health Effects, Vol. 2. R. L. Jolley, H. Gorchev, D. H. Hamilton, Jr., (ed.). Ann Arbor Science, Ann Arbor, MI.

Carpenter, J. H., C. A. Smith and R. G. Zika. 1981. Reaction products from the chlorination of seawater. Report \# PB81-172280 to Environmental Research Lab., Gulf Breeze, FL. Available from NTIS, Springfield, VA.

Conine, J. W. 1975. Ketonitrophenols from mestranol and related compounds. J. Pharmaceutical Sciences 64:777-781.

Dilling, W. L., C. J. Bredeweg and N. B. Tefertiller. 1976. Organic photochemistry. Simulated atmospheric photodecomposition rates of methylene chloride, 1,1,1-trichloroethane, trichloroethylene, tetrachloroethylene and other compounds. Environ. Sci. Technol. 10: $351-356$.

Dowty, B. J., D. R. Carlisle and J. L. Laseter. 1975. New Orleans drinking water sources tested by gas chromatography-mass spectrometry. Env. Science and Technol. 9i:762-765.

Dressler, M. 1979. Extraction of trace amounts of organic compounds from water with porous organic polymers. J. Chromatog. 165:167-206.

Eppley, R. W., E. H. Renger and P. M. Williams. 1976. Chlorine reactions with sea water constituents and the inhibition of photosynthesis of natural marine phytoplankton. Est. and Coast. Mar. Sci. 4:147-161.

Flathman, Paul E., and J. R. Dahlgren. 1982. Letter to Editor. Environ. Science and Technol. 16:130. 
Gehrs, C. W., L. 0. Eyman, R. J. Jolley and J. E. Thompson. 1974. Effects of stable chlorine-containing organics on aquatic environments. Nature 249:675-676.

Gibson, C. I., F. C. Tone, P. Wilkinson, J. W. Blaylock and R. E. Shirmer. 1980a. Toxicity, bioaccumulation and depuration of bromoform in five marine species. NUREG/CR-1297. Prepared by Battelle, Pacific Northwest Laboratory for the U.S. Nuclear Regulatory Commission.

Gibson, C. I., R. E. Hillman, P. Wilkinson and D. L. Woodruff. 1980b. Growth and histological effects to Protothaca staminea (Littleneck Clam) of long-term exposure to chlorinated sea water. NUREG/CR-1298. Prepared by Battelle, Pacific Northwest Laboratory, for the U.S. Nuclear Regulatory Commission.

GTaze, W. H., and J. E. Henderson, IV. 1976. Formation of organochlorine compounds from the chlorination of a municipal secondary effluent. J. Water Pollut. Cont. Fed. 47:2511-2515.

Glaze, W. H., G. R. Peyton and R. Rawley. 1977. Total organic halogen as water quality parameter: adsorption/microcoulometric method. Env. Sci. Tech. 11:685-690.

Glaze, W. H., F. Y. Saleh and W. Kinsley, 1980. Characterization of nonvolatile halogenated compounds formed during water chlorination. In: Water Chlorination, Environmental Impact and Health Effects, $\overline{V 01}$ 3, R. L. Jolley, Ed. Ann Arbor Science Publishers, Inc., Ann Arbor, MI. pp. 99-108.

Glaze, W. H., J. L. Burleson, J. E. Henderson IV, P. C. Jones, W. Kinstley, G. R. Peyton, R. Rawley, F. Y. Saleh and G. Smith. 1982. Analysis of chlorinated organic compounds formed during chlorination of wastewater products. Report \# EPA-600/4-82-072 to ERL/ORD/USEPA, Athens, GA 30613. Available from NTIS, Springfield, VA.

Hal1, L. W., Jr., G. R. Helz and D. T. Burton. 1981. Power plant chlorination: A biological and chemical assessment. Ann Arbor Science, Ann Arbor, MI.

Hamilton, D. H. 1978. Chlorine application for the control of condensor fouling. In: Water Chlorination, Environmental Impact and Health Effects. V 2. R. L. Jolley, Ed., Ann Arbor Science, Ann Arbor, MI. pp. 687-693.

Helz, G. R., D. A. Dotson and A. C. Sigleo. 1983. Chlorine demand: studies concerning its chemical basis. In: Water Chlorination: Environmental Impact and Health Effects, Vol. 4, R. L. Jolley, (ed.) Ann Arbor Science, Ann Arbor, MI. pp. 181-190. 
Helz, G. R., A. C. Sigleo and C. A. Hill. 1980. Mechanisms of chlorine degradation in natural waters. In: Water Chlorination: Environmental Impact and Health Effects. Vol. 3. R. L. Jolley, (ed.) Ann Arbor Science, Ann Arbor, MI. pp. 387-394.

Helz, G. R., and R. Y. Hsu. 1978. Volatile chloro- and bromocarbons in coastal waters. Limnol. Oceanog. 23(5):858-869.

Jolley, R. L. 1975. Chlorine-containing organic constituents in chlorinated effluents. J. Water Pollut. Cont. Fed. 47:601-618.

Jolley, R. L., W. W. Pitt, Jr., F. G. Taylor, Jr., S. J. Hartmann, G. Jones, Jr. and J. E. Thompson. 1978. An experimental assessment of halogenated organics in waters from cooling towers and once-through systems. pp. 695-706. In: Water Chlorination: Environmental and Health Effects. Vol. 2. R. L. Jolley, H. Gorchev and D. H. Hamilton, Jr., (ed.). Ann Arbor Science, Ann Arbor, MI.

Junk, G. A., J. J. Richard, M. D. Brieser, D. Witiak, J. L. Witiak, M. D. Arguello, R. Vick, H. J. Svec, J. S. Fritz and G. B. Calder. 1974. Use of macroreticular resins in the analysis of water for trace organic contaminants. J. Chromatog. 99:745-762.

Karickhoff, S. W., D. S. Brown and T. A. Scott. 1979. Sorption of hydrophobic pollutants on natural sediments. Water Res. $13: 241-248$.

Krijgsman, W., and C. G. Van de Camp. 1977. Determination of chlorophenols by capillary gas chromatography. J. Chromatog. $131: 412-416$.

Minear, R. A., and J. C. Bird. 1980. Trihalomethanes: Impact of bromide ion concentration on yield, species distribution, rate of formation and influence of other variables. In: Water Chlorination: Environmental Impact and Health Effects. Vol. 3, R. L. Jolley, (ed.) Ann Arbor Science, Ann Arbor, MI. pp. 151-160.

01iver, B. G. 1980. Effect of temperature, $\mathrm{pH}$ and bromide concentration on the trihalomethane reaction of chlorine with aquatic humic material. In: Water Chlorination: Environmental Impact and Health Effects, $\sqrt{01}$. 3, R. L. Jolley, (ed.) Ann Arbor Science, Ann Arbor, MI. Pp. 141-150.

Osterroht, C. 1974. Development of a method for the extraction and determination of non-polar, dissolved organic substances in sea water. J. Chromatog. 101:289-298.

Picer, N., and M. Picer. 1980. Evaluation of macroreticular resins for the determination of $10 \mathrm{w}$ concentrations of chlorinated hydrocarbons in sea water and tap water. J. Chromatog. 193:357-369. 
Pitts, Jr., J. N., D. M. Lokensgard, W. Harger, T. S. Fischer, V. Mejia, J. J. Schuler, G. M. Scorziell and Y. A. Katzenstein. 1982. Mutagens in diesel exhaust particulate. Mutation Research 103:241-249.

Riley, R. G., E. A. Crecelius, D. C. Mann, K. H. Abel, B. L. Thomas and R. M. Bean. 1980. Quantitation of pollutants in suspended matter and water from Puget Sound. NOAA Technical Memorandum, ERL MESA-49, National Oceanic and Atmospheric Administration, Boulder, CO.

Roesijadi, G., S. R. Petrocelli, J. W. Anderson, C. S. Giam and G. E. Neff. 1976. Toxicity of polychlorinated biphenols (Aroclor 1254) to adult, juvenile, and larval stages of the shrimp, Palaemonetes pugi. Bull. Env. Contam. and Toxicol. 15:297-304.

Rook, J. J. 1974. Formation of haloform during chlorination of natural waters. Water Treat. and Exam. 23:234-243.

Saleh, F. Y., and M. Mokti. 1983. Fulvic acid and chlorinated fulvic acid in water and sediment: HPLC fractionation and spectroscopic characterization. In: Water Chlorination: Environmental Impact and Health Effects. Vol. 4., R. L. Jolley, (ed.) Ann Arbor Science, Ann Arbor, MI. pp. 99-116.

Saunier, B., and R. E. Selleck. 1976. Kinetics of breakpoint chlorination and of disinfection. Sanitary Engineering Research Laboratory Report No. 76-2. University of California, Berkeley, CA.

Seaman, C. V., L. O. Hill, B. W. Vignon, T. B. Stanford and M. D. Hunter. 1983. Halogenated organic study at selected Tennessee Valley Authority fossil-fueled power plants. In: Water Chlorination: Environmental Impact and Health Effects. Vol. 4., R. L. Jolley, (ed.) Ann Arbor Science, Ann Arbor, MI. pp. 373-382.

Smith, J. H., J. C. Harper and B. DaRos. 1983. Atmospheric emissions from electric power plant cooling systems. In: Water Chlorination: Environmental Impact and Health Effects. Vol. 4., R. L. Jolley, (ed.) Ann Arbor Science, Ann Arbor, MI. pp. 391-404.

Suffet, I. H., L. Breener and B. Silver. 1976. Identification of 1,1,1-trichloroacetone in two drinking waters: a known precursor in haloform reaction. Env. Sci. and Tech. 10:1273-1275.

Thomas, R. F., M. J. Weisner and H. J. Brass. 1980. The fifth trihalomethane: dichloroiodomethane, its stability and occurrences in chlorinated drinking water. In: Water Chlorination, Environmental Impact and Health Effects. Vol. 3., R. J. Jolley, Ed., Ann Arbor Science Publishers, Inc., Ann Arbor, MI. Pp. 161-170. 
U.S. Environmental Protection Agency. 1982. Steam electric power generating point source category; effluent 1 imitations guidelines, pretreatment standards, and new source performance standards. Federal Register 47:52290-52309.

U.S. Nuclear Regulatory Commission. 1978. Final addendum to the fuel environmental statement related to the operation of Palisades Nuclear Generating Plant. NUREG-0343. Available from NTIS, Springfield, VA.

Van Rossum, P., and R. G. Webb. 1978. Isolation of organic water pollutants by XAD resins and carbon. J. Chromatog. 150:381-392.

Wegman, R. C. C., and H. H. van den Broek. 1983. Chlorophenols in river sediment in the Netherlands. Water Res. 17:227-230.

Weil, I., and J. C. Morris. 1949. Kinetic studies on the chloramines. I. The rate of formation of monochloramine, N-chlormethylamine and $\mathrm{N}$-chlordimethylamine. J. Am. Chem. Soc. 71:1664.

Zitko, V., and 0. Hutzinger. 1976. Uptake of Chloro- and bromobiphenyls, hexachloro- and hexabromobenzene by fish. Bull. Env. Contr. and Toxic. 16:665-673. 
In addition to the samples which are described in the procedures section, two additional samples were taken that proved to be invaluable later. Bulk water samples, taken directly out of the water source, were taken in one-liter glass bottles with teflon-lined caps. These were taken in triplicate at each water source sampled. In addition, extra XAD-2 columns were taken in case of leaks or other accidents. If these were not used, they could be analyzed as "trip blanks". Water volumes for XAD sampling were cut in half after the first three plants were sampled because analyses indicated that our methods were adequate to handle the smaller sample sizes. In addition, turbidity and dissolved oxygen measurements were not taken at all stations, because the equipment did not stand up to the rigors of the fieid. Tissue samples were collected only at the Millstone Plant, and this task was subsequently dropped from the sampling protocol because of difficulty in finding suitable specimens at other locations. In addition to the sediment core samples, one-liter bulk sediment ( $2 \mathrm{~cm}$ surface layer) samples were taken at discharge and control locations, at Beaver Valley, Trojan and Palisades plants. 
I. SAMPLING SOURCE WATER

A. PRIOR TO SAMPLING

1. prime and start pumping with high capacity pumps

2. calibrate $\mathrm{pH}$ meter

3. monitor TRC in discharge

B. TAKING 200-LITER SAMPLE

1. at signal, begin filling the $200 \mathrm{~L}$ PVF barrels

2. acidify to $\mathrm{pH} 4.5-5.0$

a. add $\mathrm{H}_{2} \mathrm{SO}_{4}$ at intervals as barrels fill

b. monitor with $\mathrm{pH}$ meter

3. add predetermined amount of $\mathrm{Na}_{2} \mathrm{SO}_{3}$ to PVF barrel to deactivate the residual chlorine

4. stop pumping before chlorination cycle is complete

II. XAD-2 RESIN COLUMN EXTRACTIONS

A. INITIAL PROCEDURE

1. pump water with a low capacity, high pressure lab pump

2. resin columns are arranged in the following configuration:

from barrel
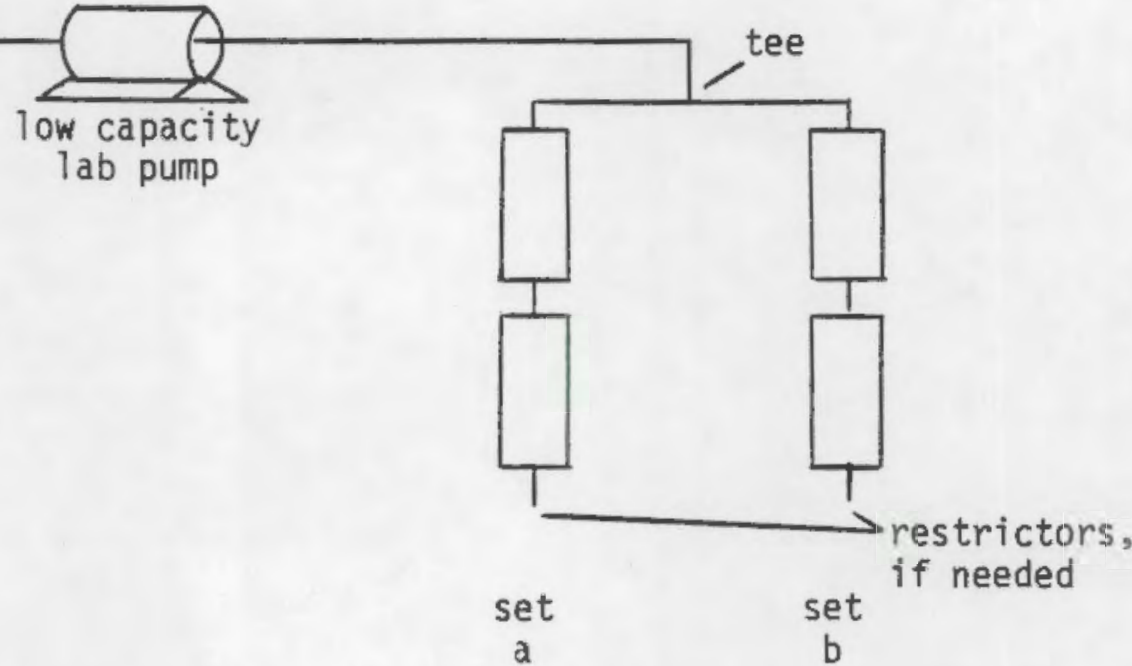

Note: the columns will be numbered in a series, arrange so the top number in set a is the smaller number, 1ikewise for set b. i.e. 117a 119b

$\stackrel{+}{118 \mathrm{a}} \quad \stackrel{+}{120 \mathrm{~b}}$ 
3. the discharge from each set of columns is to be collected in a separate container (garbage can) for accurate volume determinations

4. set column discharge rates at 50 to $80 \mathrm{ml} / \mathrm{min}$

\section{B. FINAL PREPARATIONS}

1. repeat IB as necessary to obtain a $200 \mathrm{~L}$ sample per column set

2. when re-filling PVF barrel, keep lab pump running in normal manner

III. PURGE AND TRAP SAMPLES

A. SAMPLING

1. with spare pump, fill a $120 \mathrm{ml}$ vial to capacity

2. seal with black "HYCAR" septa, ensuring no air bubbles are present

B. SAMPLE INVENTORY

1. stagger samples to allow at least 2 per 200 L PVF barrel

2. take a total of 6 samples.

C. LABELING

1. wrap with green tape, then white labeling tape

2. identification consists of:
a. site
b. type of sample
c. location
d. barrel/replicate designation
e. date

Example Millstone Purge and Trap Chlorinated

B-3

$6 / 25 / 80$

IV. HEXANE EXTRACTIONS

A. SAMPLING

1. Use spare lab pump

2. subsample $2.0 \mathrm{~L}$ from PVF barrel

B. EXTRACTION PROCEDURE

1. add $50 \mathrm{ml}$ hexane

2. Shake vigorously with venting for $60 \mathrm{sec}$.

3. allow layers to separate (hexane on top)

4. drain aqueous layer into second sep. funnel

5. collect hexane in amber bottle

6 . repeat $1-5$ once again

7. seal the $100 \mathrm{ml}$ hexane sample with teflon tape 
C. SAMPLE INVENTORY

1. at least one extraction per PVF barrel to a total of 3 samples

2. identification consists of:
a. site
b. type of sample
c. location
d. barrel/replicate designation
DAEC
hexane
control/intake
e. date
2-A
$6 / 22 / 80$

Examp le

V. METHYLENE CHLORIDE EXTRACTIONS

A. SAMPLE PREPARATION

1. subsample 2.0 liters from PVF barre1 with spare lab pump

2. acidify to $\mathrm{pH} \leq 2$ with $36 \mathrm{~N} \mathrm{H}_{2} \mathrm{SO}_{4}$ (approx. $1 \mathrm{ml}$ )

B. EXTRACTION PROCEDURE

1. add $50 \mathrm{ml} \mathrm{CH}_{2} \mathrm{Cl}_{2}$

2. shake vigorously with venting for $60 \mathrm{sec}$

3. allow layers to separate $\left(\mathrm{CH}_{2} \mathrm{Cl}_{2}\right.$ on bottom)

4. draw off $\mathrm{CH}_{2} \mathrm{Cl}_{2}$ into amber bottle

5. repeat 1-4 once more

6 . seal amber bottle with teflon tape

C. SAMPLE INVENTORY - identical to hexane samples

D. LABELING - identical to hexane samples

VI. FILTERED WATER (through $0.2 \mu$ filters)

1. three $125 \mathrm{ml}$ samples

VII. MISCELLANEOUS WATER QUALITY MEASUREMENTS

A. Temperature
1. intake source
2. discharge source
3. PVF barrels twice daily

with each sampling into

PVF barrel

8. Dissolved $\mathrm{O}_{2}$
1. intake source
2. discharge source

with each PVF barrel sample 
C. TURB IOITY

$\left.\begin{array}{l}\text { 1. } \text { intake source } \\ \text { 2. discharge source }\end{array}\right\}$

with each PVF barrel

sample

\section{ENVIRONMENTAL SAMPLING PROCEDURES}

Sediments were collected using 15-cm long, 5-cm diameter, clear Lexan plastic tubes. The bottom, or cutting edge of tube was beveled to decrease the possibility of disturbing the core. SCUBA divers pushed the tubes into the sediment by hand to a depth of at least $10 \mathrm{~cm}$. The tubes, with core, were dug out by hand and capped before being carried to the surface. Cores were carried to the surface in an upright position. On the surface, the cores were inspected to insure there was no disturbance of the core layers. Cores disturbed during sampling or transport to the surface were discarded and new samples taken. After inspection, the water layer on the top of the core was removed from the tube with a syringe. This prevents the top layer of sediment from being disturbed during freezing. Cores were frozen and stored in dry ice for transportation to the Richland laboratory.

Environmental water samples were collected in the same area as the cores. One liter of water was collected in a polyethylene bottle. This water was processed, stored and transported as described for the hexane samples collected from the $200 \mathrm{~L}$ drums.

Biological samples were collected by hand. Visual inspection of the sample sites was made. Samples were collected from observed aggregations of sessile organisms. Sessile, bivalve mollusks were the preferred organism to sample. These organisms are less likely to have moved in and out of the sample areas, therefore, are organisms that can be identified as being affected by the discharge. Most are filter feeders, pumping ambient water into and through their own biological systems. These characteristics make sessile mollusks an excellent biological sample for identifying bioaccumulated chlorination byproducts.

Three 10 by $20-\mathrm{cm}$ plastic bags were filled with whole organisms. The bagged samples were frozen and stored on dry ice for transportation to the Richiand laboratory.

\section{SEOIMENT CORES}

\section{A. SAMPLE PREPARATION}

1. take so as to leave sed/water interface undisturbed

2. leave in vertical position to freeze 
B. SAMPLE INVENTORY

1. three samples per location per site

2. identification consists of :
a. site
b. location
c. top
d. replicate designation
e. date

Example

Milistone control/intake

top

A

$6 / 18 / 80$

II. BIOTA

\section{A. SAMPLE PREPARATION}

1. collect sessile organisms

2. quantity is to be $\geq 200 \mathrm{~g}$ tissue

B. SAMPLE INVENTORY

1. take from designated locations, where available

2. identification consists of :
a. site
b. location
c. species (if readily identified)
d. date
Millstone
discharge quarry
$6 / 19 / 80$

Example

III. ENVIRONMENTAL WATER SAMPLES (near biota and core sampling sites)

A. EXTRACTION PROCEDURE

1. follow procedure outlined for III-hexane (scaled down by 50 percent)

B. SAMPLE INVENTORY

1. triplicate

2. from designated locations at each site

3. identification consists of:
a. site
b. location
c. sample type
d. replicate designation
e. date

Example

$\overline{D A E C}$

discharge canal

in situ water/hexane

c

$6 / 25 / 80$ 
TABLE A-1. Duane Arnold Energy Center

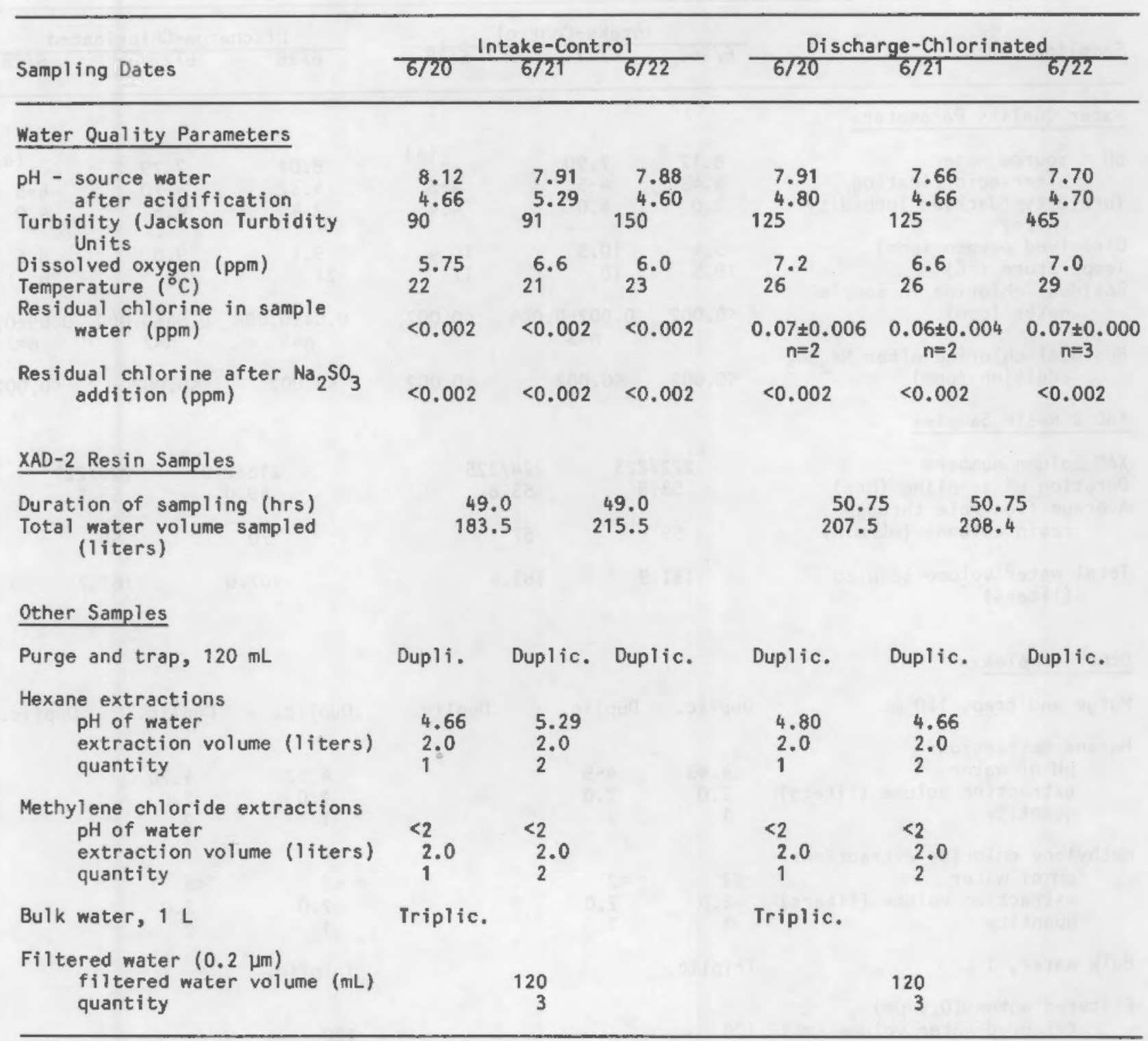


TABLE A-2. Millstone Nuclear Power Plant

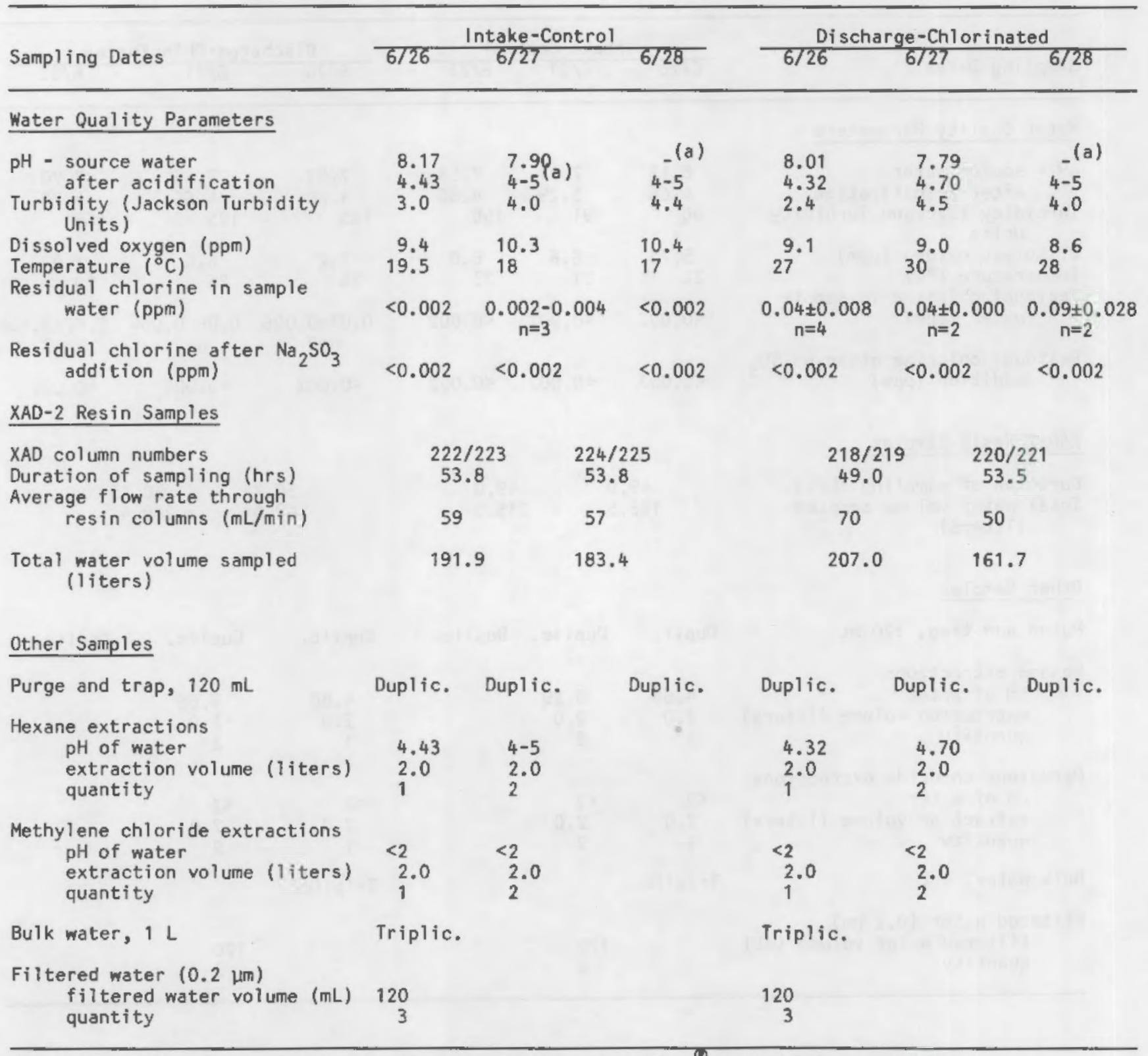

(a) $\mathrm{pH}$ meter non-operational, $\mathrm{pH}$ determined using color $\mathrm{PHast}^{(} \mathrm{pH}$ indicating sticks 
TABLE A-3. Sample Inventory - Arkansas Nuclear One

\begin{tabular}{llllll}
\hline Sampling Dates & Intake & (control) & $\begin{array}{c}\text { Unit 1 (Chlorinated) } \\
\text { (once-through cooling) }\end{array}$ & $\begin{array}{c}\text { Unit } 2 \text { (Chlorinated) } \\
\text { (closed loop cooling) }\end{array}$ & $\begin{array}{l}\text { Mixed Discharge } \\
\text { (Chlorinated) }\end{array}$ \\
\hline
\end{tabular}

\section{Water Qual ity Parameters}

$\mathrm{pH}$ - source water

after acidification

$\begin{array}{llccccc}7.7 & (a) & 8.1 & 8.2 & 8.1 & 8.1 & 8.3 \\ 4.3 & 4.5 & 3.6 & 4.2 & 4.6 & 3.6 & 4.3 \\ 10 & 10 & 10 & 10 & 42 & 54 & 10 \\ 12.8 & 12.8 & 19.5 & 19.2 & 16.0 & 19.0 & 21.0 \\ <0.002 & <0.002 & 0.68 \pm 0.03 & 0.67 \pm 0.004 & 0.29 \pm 0.002 & 0.30 \pm 0.06 & 0.58 \pm 0.03\end{array}$

Turbidity (Jackson Turbidity Units)

Temperature $\left({ }^{\circ} \mathrm{C}\right)$

Residual chlorine in sample water (ppm)

Residual chlorine after $\mathrm{Na}_{2} \mathrm{SO}_{3}$ addition (ppm)

$<0.002$

$<0.002$

$<0.002$

$<0.002$

$<0.002$

$<0.002$

$<0.002$

\section{XAD-2 Resin Samples}

Duration of sampling (hrs)

\section{8}

184

$\begin{array}{cc}\begin{array}{c}\text { Triplicate } \\ 120 \mathrm{~mL}\end{array} & \begin{array}{c}\text { Triplicate } \\ 120 \mathrm{~mL}\end{array} \\ \begin{array}{c}\text { Triplicate } \\ 2.0 \mathrm{~L}\end{array} & \begin{array}{c}\text { Triplicate } \\ 2.0 \mathrm{~L}\end{array} \\ \begin{array}{c}\text { Triplicate } \\ 2.0 \mathrm{~L}\end{array} & \begin{array}{c}\text { Triplicate } \\ 2.0 \mathrm{~L}\end{array} \\ \text { Triplicate } & \text { Triplicate } \\ \text { Triplicate } & \text { Triplicate }\end{array}$
Triplicate
$120 \mathrm{~mL}$

Triplicate

$2.0 \mathrm{~L}$

Triplicate $2.0 \mathrm{~L}$

Triplicate

Triplicate

$\begin{array}{ll}24 & 24 \\ 88 & 82\end{array}$

Triplicate $120 \mathrm{~mL}$

Triplicate $2.0 \mathrm{~L}$

Triplicate $2.0 \mathrm{~L}$

Triplicate

Triplicate 
TABLE A-4. Edwin I. Hatch Nuclear Plant

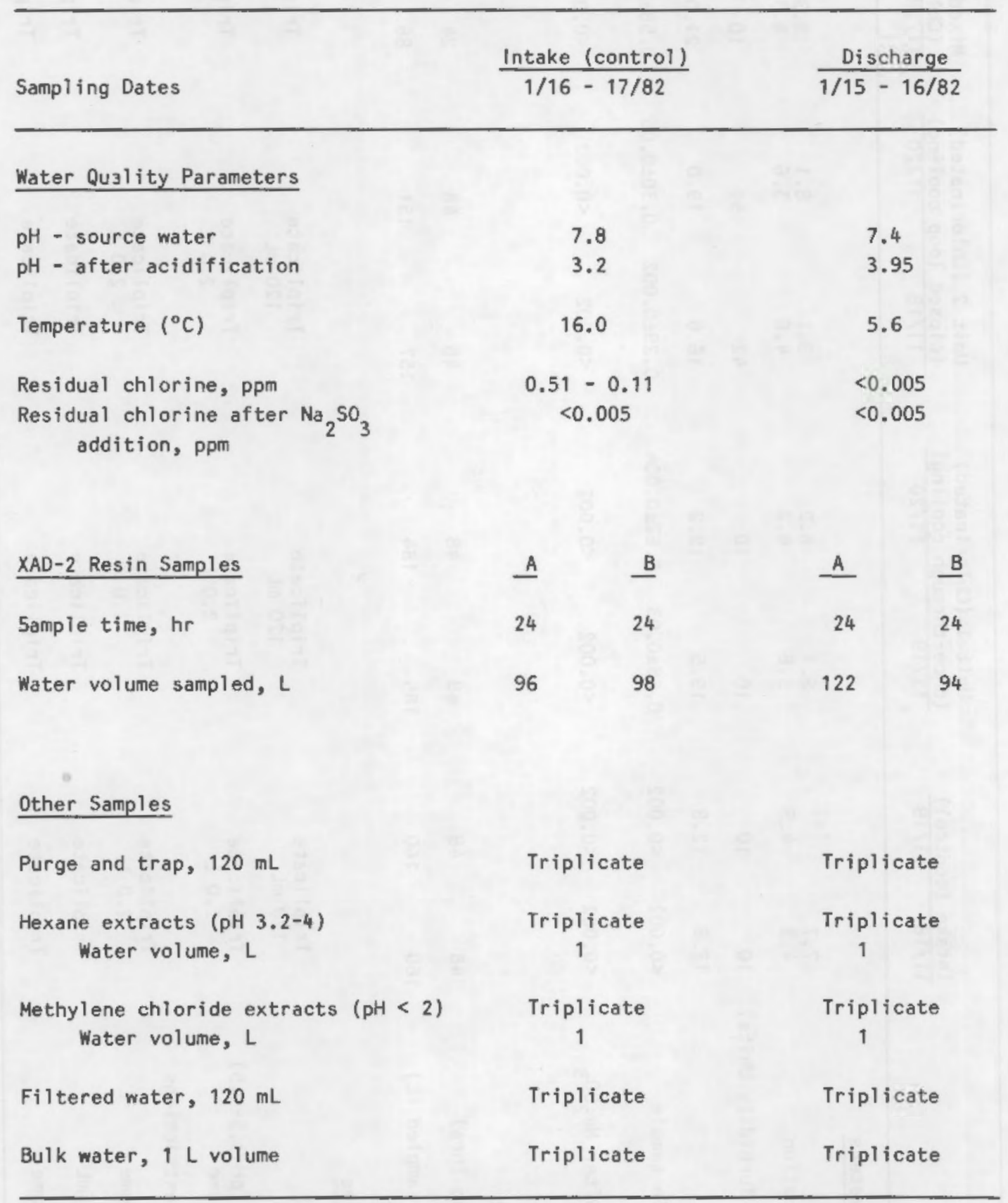


TABLE A-5. Beaver Valley Power Station

Sampiing Dates

$\frac{\text { Intake }}{7 / 20-21 / 82}$

Cooling Tower

Discharge

Water Quality Parameters

$\mathrm{pH}$ - source water

7.2

7.2

7.2

- after acidification

4.5

4.0

4.1

Temperature, ${ }^{\circ} \mathrm{C}$

27.5

27.0

28.5

Residual chlorine, ppm

$<0.005$

$0.04-0.17$

$0.17-0.18$

Residual chlorine after $\mathrm{Na}_{2} \mathrm{SO}_{3}$

$<0.005$

$<0.005$

$<0.005$ addition, ppm

$\underline{X A D-2}$ Resin Samples

Sample time, hr

Water volume sampled, L
$\underline{A}$

24

100
B

24

100
A

24

100
24

100
A $\quad$ B

\section{Other Samples}

Purge and Trap, $120 \mathrm{~mL}$

Hexane extracts $\left(\mathrm{pH}_{4-4.5)}\right.$ Water volume, L

Methylene chloride extract $(\mathrm{pH}<2)$ Water volume, L

Filtered water, $120 \mathrm{~mL}$

Bulk water, $1 \mathrm{~L}$

\begin{tabular}{ccc} 
Triplicate & Triplicate & Triplicate \\
Triplicate & Triplicate & Triplicate \\
Triplicate & 1 & 1 \\
1 & Triplicate & Triplicate \\
Triplicate & 1 & 1 \\
Triplicate & Triplicate & Triplicate \\
\hline
\end{tabular}


TABLE A-6. Trojan Nuclear Plant

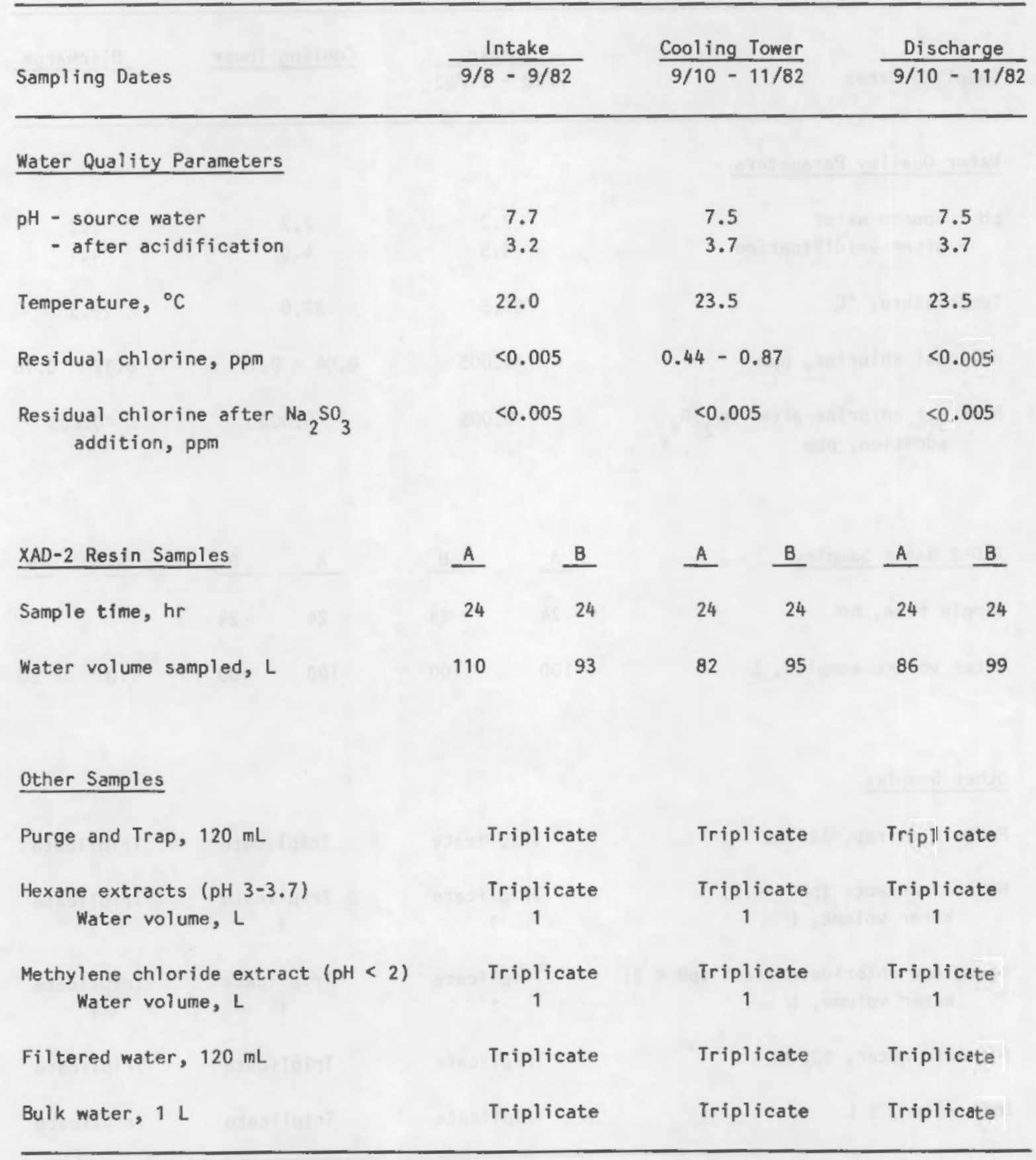


TABLE A-7. Palisades Nuclear Generating Plant

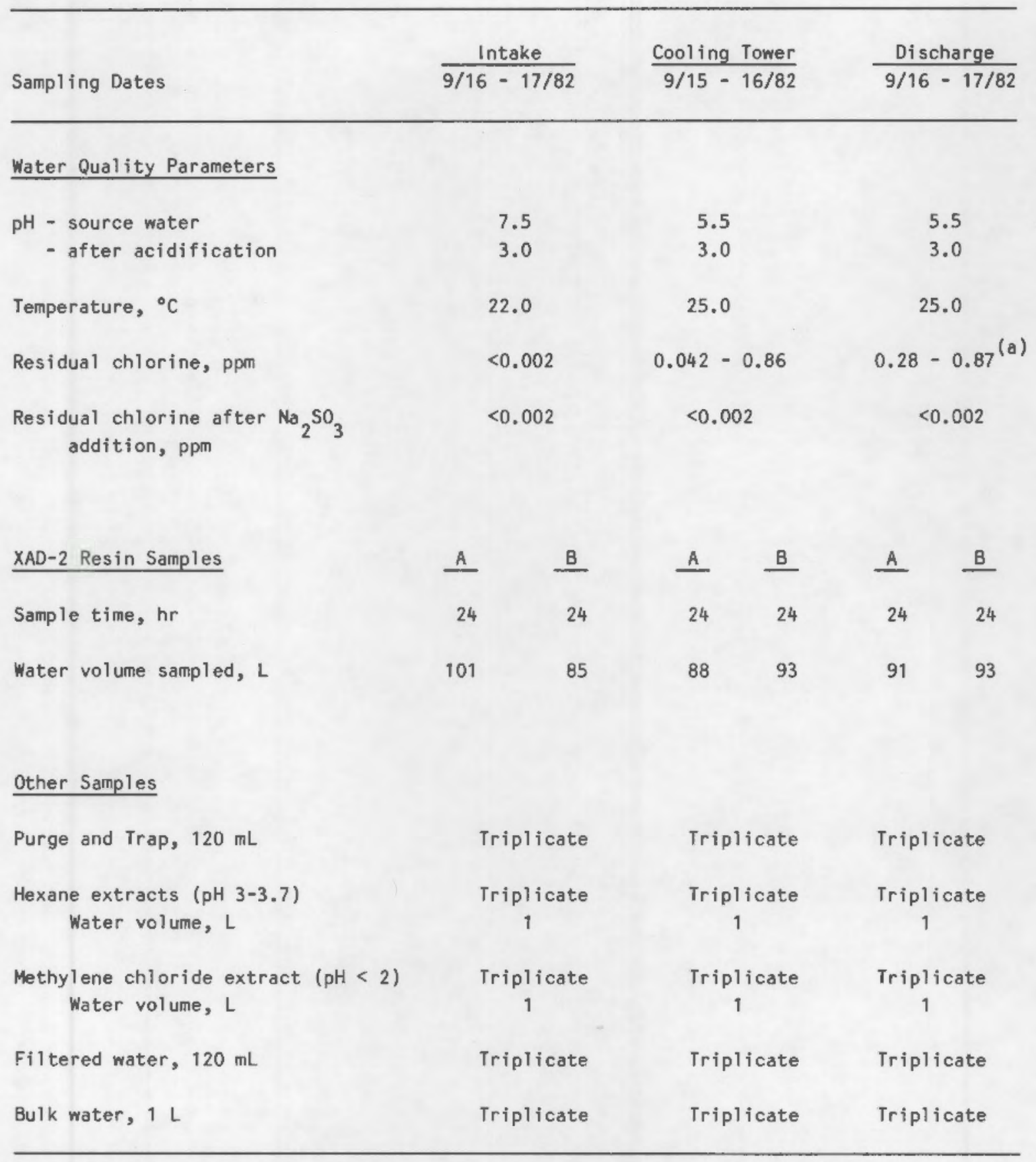

(a) TRC measured was higher than actually discharged because of incomplete mixing at sample point 


\section{APPENDIX B}

SAMPLING AND ANALYSIS OF COOLING TOWER ATMOSPHERE

FOR VOLATILE HALOGENATED ORGANICS

(Edwin I. Hatch Nuclear Plant, January 15-17, 1983) 


\section{APPENDIX B}

\section{SAMPLING AND ANALYSIS OF COOLING TOWER ATMOSPHERE FOR VOLATILE HALOGENATED ORGANICS}

(Edwin I. Hatch Nuclear Plant, January 15-17, 1983)

\section{B.1 INTRODUCTION}

During the first phase (1980) of the power plant sampling program, it became clear that cooling towers could influence the haloform concentrations in the cooling water discharge. Lower concentrations of haloforms were found in the discharge from the Arkansas cooling tower (Unit \#2) than from Arkansas Unit \#1, a once-through unit, even though chlorine concentrations were higher and residence times longer in the tower. This presented the strong possibility that haloforms formed during chlorination of power plant cooling waters could be lost through evaporation to the atmosphere. This observation was in agreement with data presented by Jolley et al. (1978), indicating that haloforms could be stripped from cooling water during evaporative cooling. Later, Smith, et a1. (1980) presented measurements of haloform concentrations in tower riser water which indicated substantial losses of haloforms during cooling. Simultaneous measurements of the tower atmosphere by these workers did not detect sufficient haloform to account for the losses from the riser water. However, poor collection efficiency of the sampler was a probable cause for the very low haloform concentrations found. In order to provide additional evidence of haloform evaporation from cooling towers, a sampling of the exhaust atmosphere at the E. I. Hatch Nuclear Plant was incorporated into our power plant sample program. Sampling was conducted by personnel from the Atmospheric Sciences and Environmental Sciences Departments of the Pacific Northwest Laboratory.

\section{B.2 SAMPLING AND ANALYTICAL PROCEDURES}

The task of identifying and quantitatively measuring the atmospheric release of gaseous material during cooling tower operation represents a significant department from routine source characterization. General operational features of forced draft towers were considered in designing a general protocol. As opposed to more typical source sampling tasks, the following considerations, unique to the cooling tower problem, were recognized and explored in terms of the tower to be sampled: 
- Tower dimensions and the relative upstream distance between vapor release from the cooling water and the top of the tower suggest that vapor concentration may vary across the effluent stream. The cooling tower therefore represents a source in which effluent concentration is non-uniform.

- Organohalogen vapor concentration undoubtedly changes dramatically with time. Peak release is expected to occur during or soon after the chlorination process and decay in an exponential manner to near zero within a period of 1-2 hours.

- Unlike stack effluent characterization, sampling must be conducted at the top of the tower rather than through upstream ports.

- Significant levels of liquid water will be encountered in the test environment. This was recognized in selecting pumps and installing them for the sampling task. The impact of liquid water on the vapor adsorption column was considered in the design of a sampling device and a means to separate liquid water from the vapor stream being sampled devised.

The air flow characteristics of a mechanical (forced) draft cooling tower are complex. A plot of air flow from a typical 10-meter diameter tower is shown in Figure B.1. Because of the variability expected, sampling was conducted at two different distances from the run of the Hatch Tower; 0.9 and 2.7 meters. The sampling device used to measure the air flow, air temperature, and to take the volatile organohalogen sample is shown in Figures B.2 and B.3. One device was positioned at each sample location (Figure B.4). Air flow was measured with Gill propeller anemometers, air temperature with thermisters. As the illustrations show, the samplers were positioned at their location using a system of trolley tracks and wheels. Guy wires for securing the trolley system are not shown in Figure B.4.

The vapor collection device consisted of two tubes in series (Figure B.3) packed with an adsorbent polymer material, Tenax-GC. The packed columns are preceded by an impinger to capture liquid water droplets which would interrupt sample flow by altering the pressure drop across the columns. Effluent samples were pulled through the sampling device using pumps located at the perimeter of the tower in order to minimize contact with moisture laden air (Figure B.4). The pumps were battery operated units for personnel exposure measurements in workplace environments. They offer adequate flow while eliminating electrical hazards associated with the use of AC power lines. Flowmeters were 


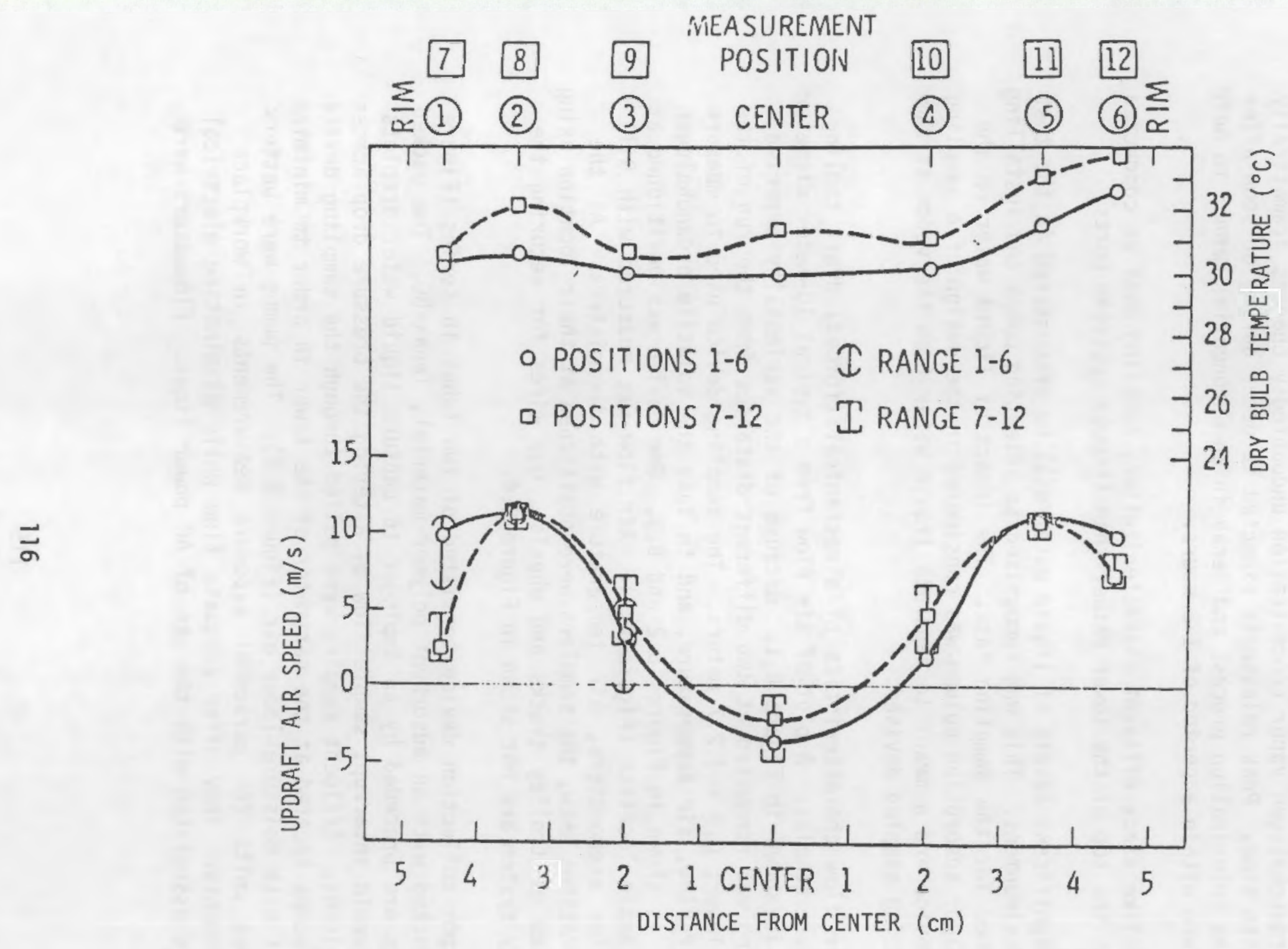

FIGURE B.1. Forced Draft Cooling Tower Characteristics: Data from the Report "Drift Measurements from Mechanical Draft Cooling Towers" Prepared by Cooling Systems Projects Group, Environmental Systems Corporation for Electric Power Research Institute. October 1978 


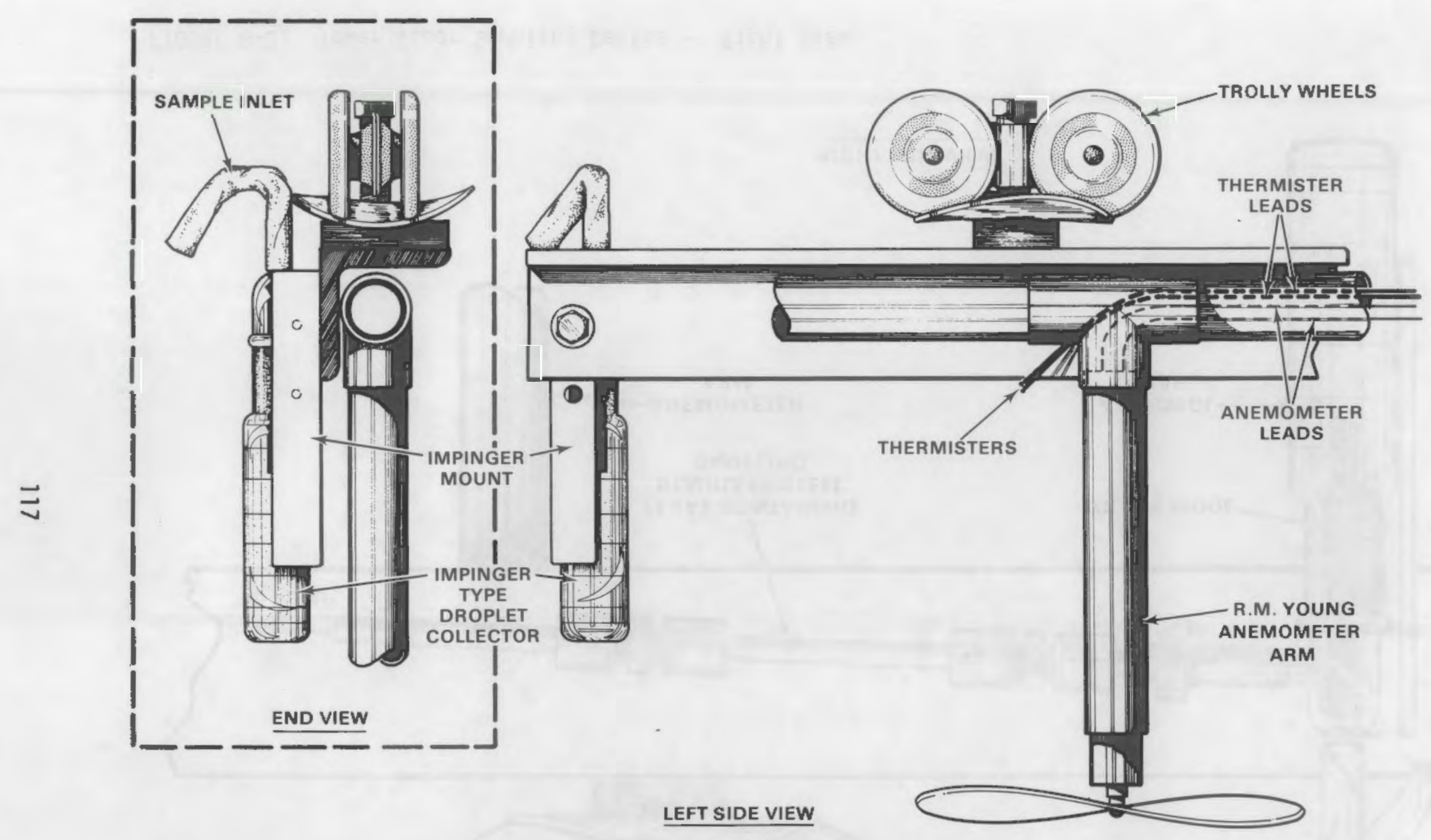

FIGURE B-2. Tower Vapor Sampling Device -- Left View 


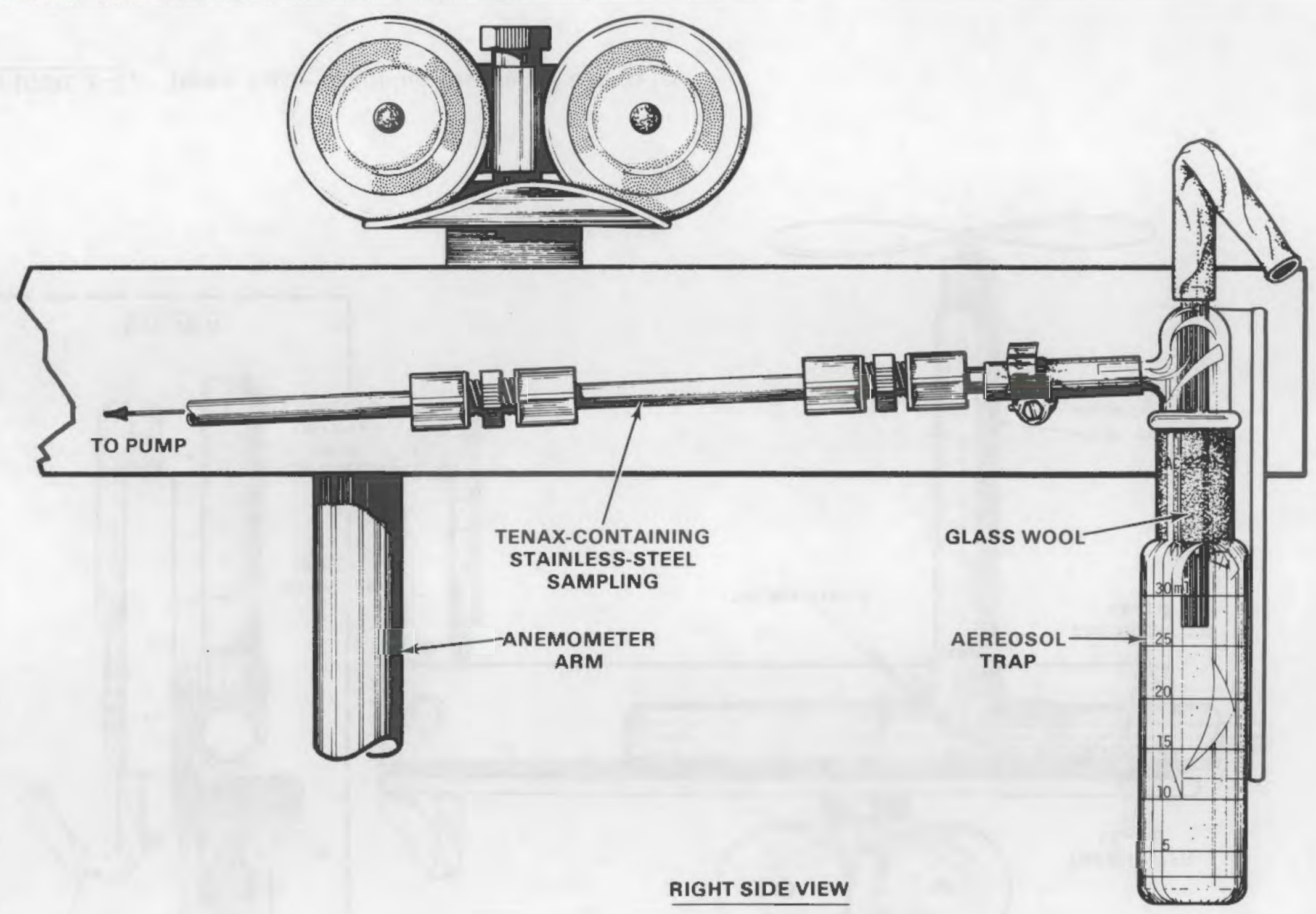

FIGURE B-3. Tower Vapor Sampling Device -- Right View 


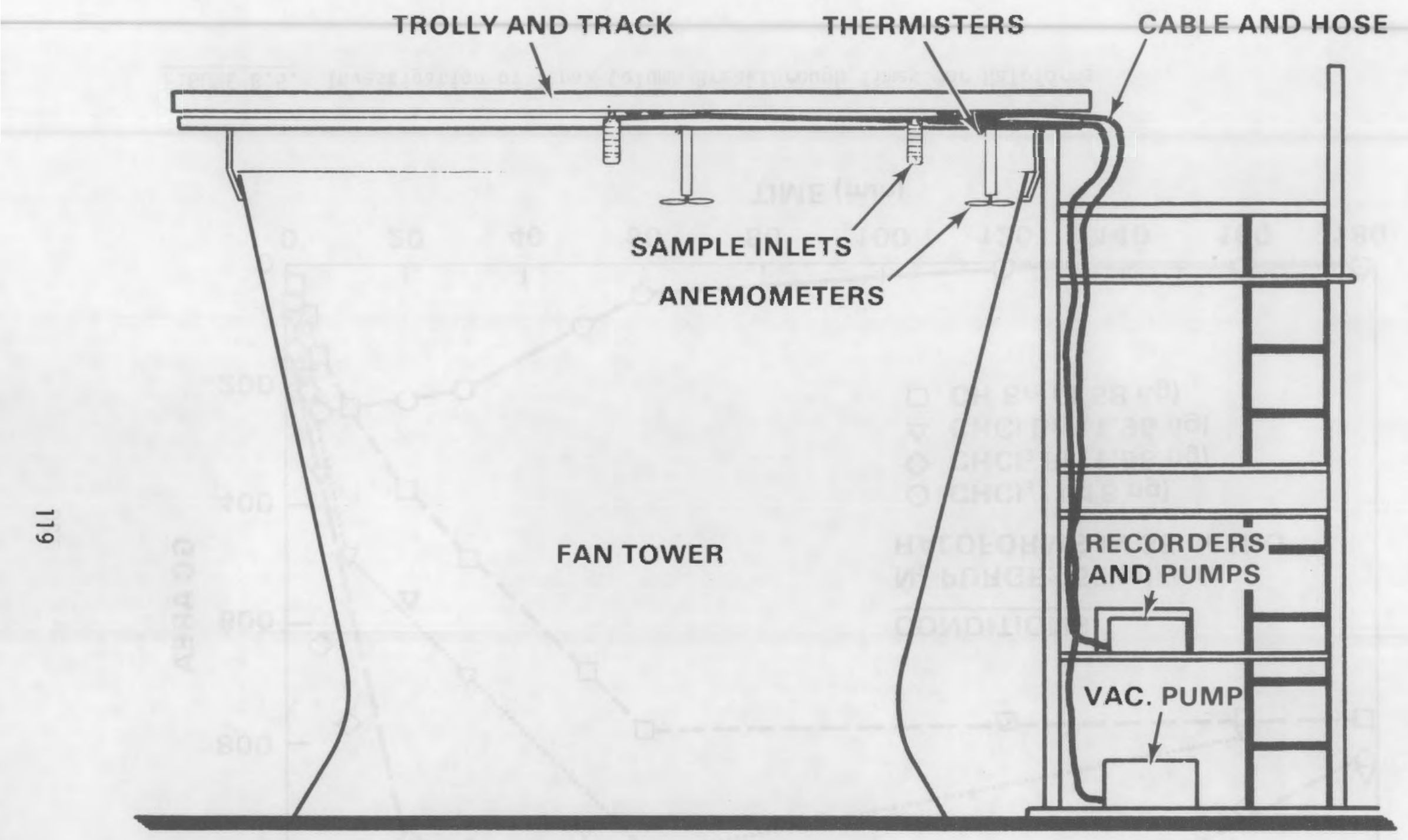

FIGURE B-4. General Placement of Sampling Device and Supporting Equipment 


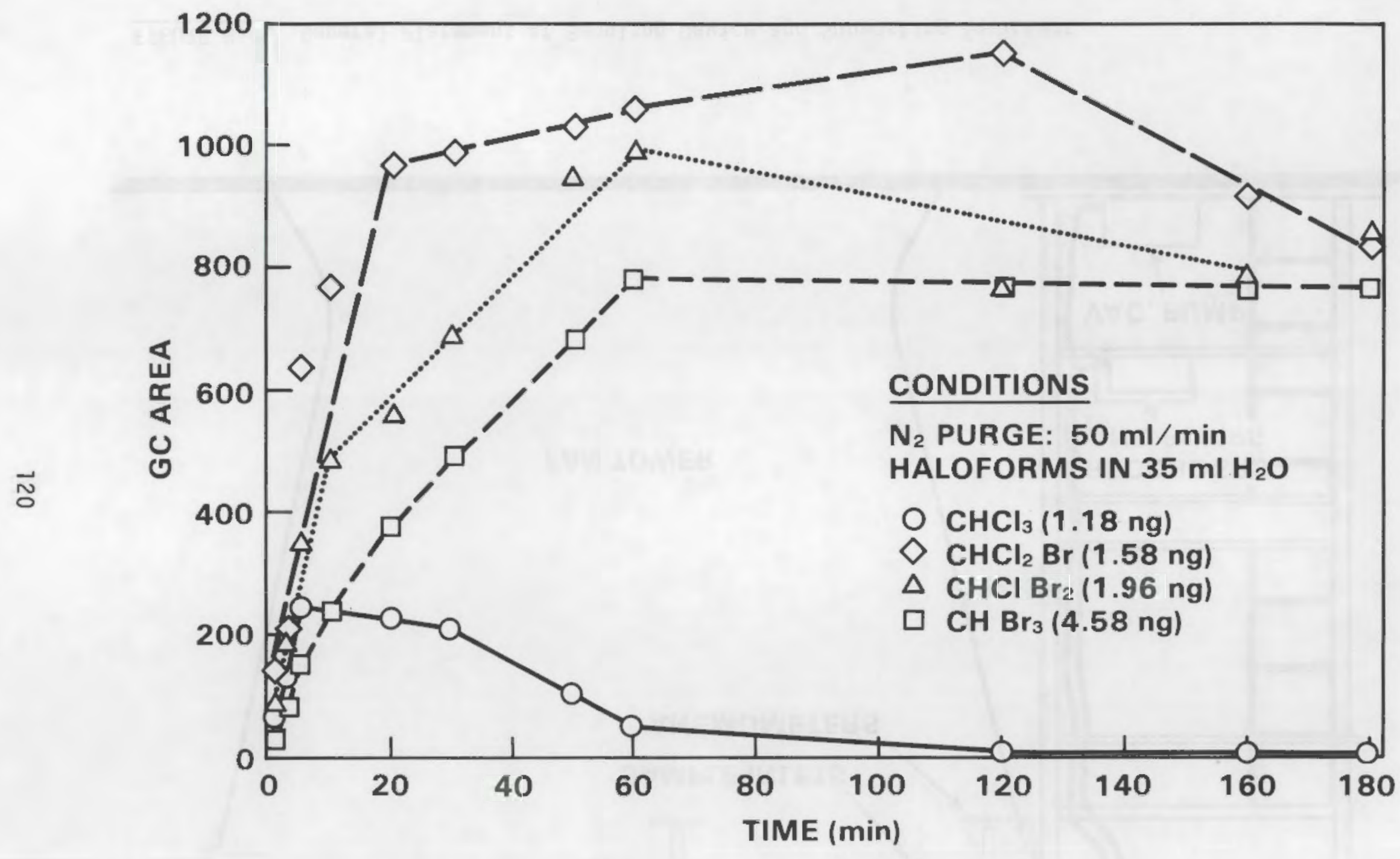

FIGURE B.5. Investigation of Tenax Column Breakthrough Times for Haloforms 
placed in the sampling lines, downstream from the adsorption tubes, to permit monitoring of sample flow rates. In addition to sample collection at the time of chlorination, samples exposed prior to chlorination and well after chlorination were taken as controls.

Adsorption sampling tubes used for sampling were $1 / 4^{\prime \prime}$ stainless steel containing Tenax resin, purchased from Envirotest, Inc. These columns have been used successfully for purge and trap analysis of volatiles in chlorinated waters during the course of the program.* Sampling and analysis of air pollutants using Tenax Resin columns have been extensively documented by Pellizzari for the USEPA.**

Prior to taking the sampling tubes out in the field, each were heated to $200^{\circ} \mathrm{C}$ in a stream of inert gas for 30 minutes and transferred to a sealed teflon-lined vial containing nitrogen. The tubes were kept sealed in the vials until immediately before use, and replaced in the vials irmediately after sample collection.

The samples were analyzed by heating the Tenax column to $200^{\circ} \mathrm{C}$ in a stream of carrier gas which forces the sample onto a $6-\mathrm{ft}$. 1ong, $2 \mathrm{~mm}$ ID glass chromatographic column packed with $0.2 \%$ Carbowax 1500 on Carbopack. Analysis of sample components analyzed were principally the four trihalomethanes (THM). Detection was by mass spectrometer.

Prior to sampling, the Tenax columns were calibrated for capacity at the anticipated gas collection flows by 1) placing 1-5 $\mu \mathrm{g}$ quantities of the four haloforms into a purge-and-trap apparatus and puring for various times to detect the breakthrough times for the various haloform compounds. These results are shown in Figure B.5. The only component which posed a breakthrough problem was chloroform, which diminished significantly in response after about 20 minutes of purging. The breakthough behavior of chloroform directly injected onto the Tenax column was further investigated. The resuits of this test, shown in Figure B.6, confirmed that 20 minutes at $40 \mathrm{ml} / \mathrm{min}$ gas flow was the

* R. M. Bean, D. C. Mann, R. G. Riley. Analys is of Organohalogen Products from Chlorination of Natural Waters Under Simulated Biofouling Control Conditions. NUREG/CR-1301.

** E. D. Pellizzari. 1977. Analys is of Organic Air Pollutants by Gas Chromatography and Mass Spectroscopy, EPA-600/2-77-100. Also, Krost, et al., 1983. Collection and Analysis of Hazardous Organic Emmissions. Anal. Chem. 54:810-817. 


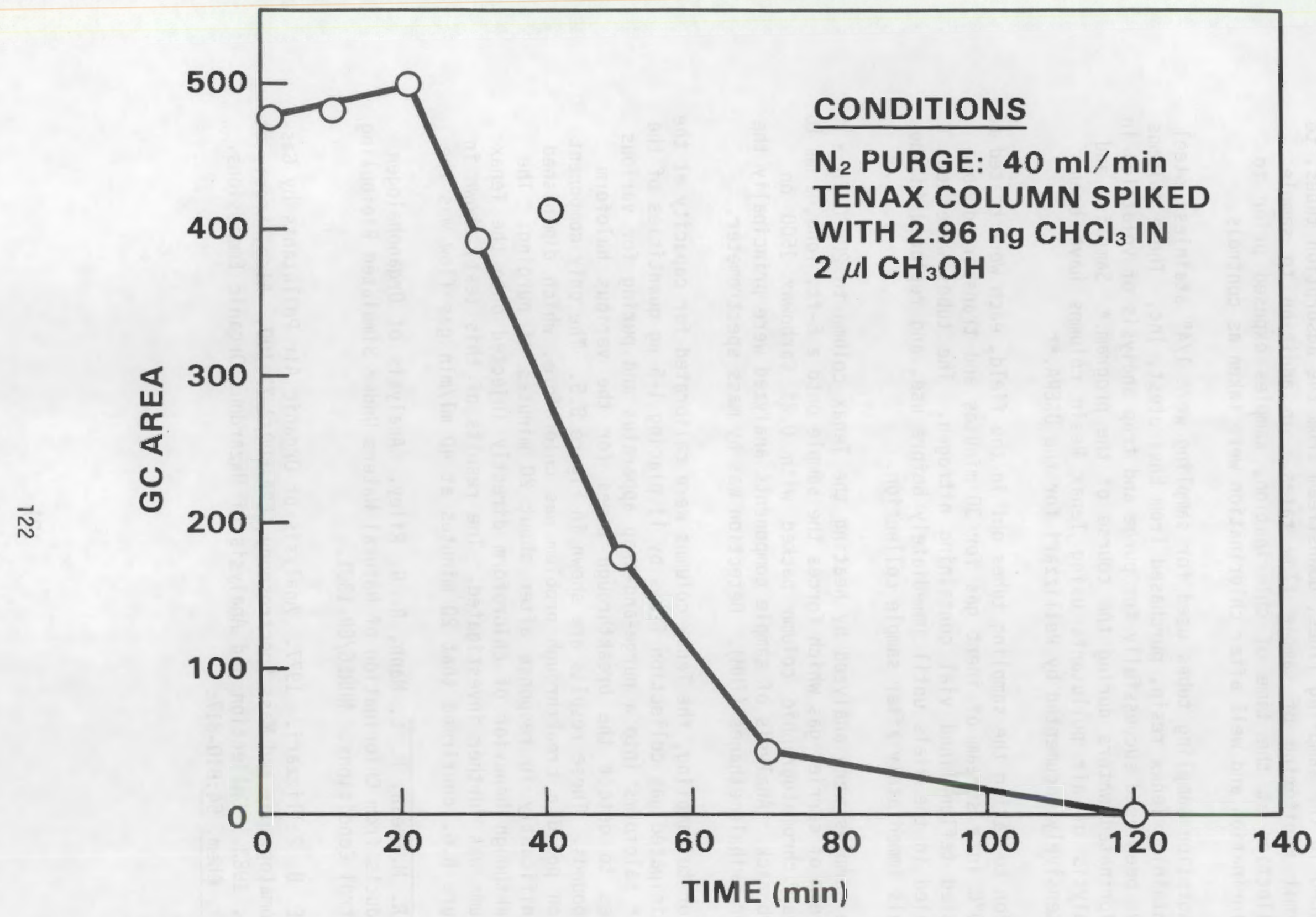

FIGURE B.6. Breakthrough Curve for Chloroform Injected Onto Tenax Sample Column 
maximum permitted when taking an actual tower atmosphere sample. Limits of detection for haloforms using mass spectrometry for component detection was $0.3-0.1 \mu \mathrm{g} / \mathrm{m}^{3}$.

A detailed description of sampling operations at the E. I. Hatch power plant is given in Section 2 of this report. The conditions prevailing during sampling at the plant are given in Table B.1.

\section{B. 3 RESULTS}

Updraft velocity measurements, temperature measurements, total residual chlorine determinations, and vapor samples taken for the tower atmosphere sampling at E. I. Hatch plant, are given in Tables B.2 through B.4. The measured updraft velocity of the cooling tower at the Hatch Plant and the tower profile data from Figure B.1 were used to calculate the volumetric flow from a single cooling tower unit at that plant. Since the Hatch Plant tower dimensions and measured updraft are essentially those cited in Figure B.1, the calculated flow, and the assumptions made in deriving it, are justified. The following is a summary of pertinent data and assumptions used in the flow calculation:

Sampling positions (meters from tower rim): 0.76 and 2.3 .

Maximum updraft velocity (Jan. $16 \& 17$ ): $11 \mathrm{~m} / \mathrm{sec}$.

Assumptions: Tower diameter at rim; $10.7 \mathrm{~m}$ (35 ft.). Updraft area; $82.9 \mathrm{~m}^{2}$ (area with a positive updraft
velocity). Average updraft velocity $=80 \%$ of maximum. $=8.8 \mathrm{~m} / \mathrm{sec}$.

Volumetric Flow: $730 \mathrm{~m}^{3} / \mathrm{sec}$.

The haloform data obtained from the cooling tower sampling are presented in Table B.5. No chloroform was detected in the $2.7 \mathrm{~m}$ sample, but the chloroform found in the $0.9 \mathrm{~m}$ sample agreed with the expected concentration calculated from the observed chloroform loss from the tower water, assuming a linear loss over a period of 1 hour. Chloroform was only found in the chlorination backup column, not the primary column, on January 16; however, chloroform was found in both $0.9 \mathrm{~m}$ and $2.7 \mathrm{~m}$ samples on January 17 . Unfortunately, an instrument malfunction 
permitted only a crude estimate to be made of the chloroform concentration in the chlorination $2.7 \mathrm{~m}$ backup column. Further complicating the analyses was the fact that a chlorofluorocarbon contaminant was found in two of the samples. Figure B.7 and B.8 show the GC/MS spectrum of chloroform found in the Tenax sampler, and the spectrum of chloroform confounded by the contaminant. Fortunately, quantitation of the chloroform could be made using the $M=83$ peak which is not interfered with by the contaminant. The source of contamination has not been identified.

Although the data obtained from the air sampling is not consistent, and is confounded by contamination and instrumental problems, the data generally agree with that expected from the observed drop in chloroform concentration in the riser water. A troublesome observation is that the chloroform concentration in the tower water 13 hours after the last chlorination was $4.6 \mu \mathrm{g} / \mathrm{L}$ (see Table B.5B, prechlorination, January 17). This was more than 5 times higher than that measured in the discharge water collected immediately following chlorination, which was $0.77 \pm$ $0.09 \mu \mathrm{g} / \mathrm{L}$ (Section 3.2, Table 3.4). We could find no explanation for this based upon cooling water system operation. Although both air and water samples were checked for other chlorinated volatile components, none were found other than those reported in Table B.5.

The data obtained from our tower and discharge analyses are summarized in terms of chlorine accounted for in Table B.6. The data obtained are consistent with the observation made in Section 3 of this report that most of the chlorine added does not show up as organic halogen; rather, only about $1 \%$ appears as organic halogen material of sufficiently low molecular weight as to be of immediate environmental concern. 
TABLE B-1. Edwin I. Hatch Nuclear Plant (Unit \#2), Baxley, Georgia

\section{MWe Power Capacity}

Time: $\quad$ January $15-17,1982$

Weather: Rain, Wind, Sub-Zero Temperature

Altamaha River approximately 12 feet over banks at discharge.

Chlorine Added:

$$
\begin{array}{ll}
1.25 \mathrm{ppm} & \text { January } 15,1982 \\
1.67 \mathrm{ppm} & \text { January } 16,1982 \\
0.83 \mathrm{ppm} & \text { January } 17,1982
\end{array}
$$

Discharge Temperature: $44^{\circ} \mathrm{C} \odot \Delta \mathrm{T}=20^{\circ} \mathrm{C}$

\section{Cooling System}

3 Banks of 10 Cooling Towers

Volume of System: $12 \times 10^{6}$ Gallons

Circulating Water: $556,000 \mathrm{GPM}$

Evaporation and Orift Loss: $\quad 10,385 \mathrm{GPI}$

Tower Blowdown:

$$
8,915 \text { GPM }
$$


TABLE B-2. Updraft Velocity Measured at Top of Fan Tower During Vapor Sampling at Edwin Hatch Power Plant

\begin{tabular}{|c|c|c|c|}
\hline $\begin{array}{c}\text { Probe } \\
\text { Position }\end{array}$ & $\begin{array}{l}\text { Chlorination } \\
\text { Status }\end{array}$ & $\begin{array}{l}\text { Updraft } \\
\text { Velocity }(\mathrm{m} / \mathrm{s})\end{array}$ & Time (EST) \\
\hline \multicolumn{4}{|c|}{ January 16,1982} \\
\hline $0.8 \mathrm{~m}$ & Prechlorination & 11.2 & 1538 \\
\hline $2.3 \mathrm{~m}$ & Prechlorination & 10.3 & \\
\hline $0.8 \mathrm{~m}$ & Chlorination & 11.2 & 1620 \\
\hline $2.3 \mathrm{~m}$ & Chiorination & 11.9 & \\
\hline $0.8 \mathrm{~m}$ & Post chlorination & 10.4 & 1932 \\
\hline $2.3 \mathrm{~m}$ & Post chlorination & 9.9 & \\
\hline \multicolumn{4}{|c|}{ January 17,1982} \\
\hline $0.8 \mathrm{~m}$ & Prechlorination & 10.1 & 0842 \\
\hline $2.3 \mathrm{~m}$ & Prechlorination & 10.8 & \\
\hline $0.8 \mathrm{~m}$ & Chlorination & 9.9 & 0942 \\
\hline $2.3 \mathrm{~m}$ & Chlorination & 11.2 & \\
\hline $0.8 \mathrm{~m}$ & Post chlorination & 9.0 & 1240 \\
\hline $2.3 \mathrm{~m}$ & Post chlorination & 10.3 & \\
\hline
\end{tabular}


TABLE B-3. Air Temperatures Measured at Top of Fan Tower During Vapor Sampling at Edwin Hatch Power Plant

\begin{tabular}{ccc}
$\begin{array}{c}\text { Probe } \\
\text { Position }\end{array}$ & $\begin{array}{c}\text { Chlorination } \\
\text { Status }\end{array}$ & Temperature (C) Time (EST) \\
\hline
\end{tabular}

January 16,1982

Prechlorination

$0.8 \mathrm{~m}$

Start sample

End sample

27.5

28.0

1538

1620

$2.3 \mathrm{~m}$

Start sample

27.5

1538

End sample

30.0

1620

Chlorination

$0.8 \mathrm{~m}$

Start sample

26.5

1630

End sample

26.5

1654

$2.3 \mathrm{~m}$

Start sample

29. D

1630

End sample

27.5

1654

Post Chlorination

$0.8 \mathrm{~m}$

Start sample

26.0

26.0

1935

End sample

26.0

2000

January 17,1982

Prechtorination

$\begin{array}{llll}0.8 \mathrm{~m} & \begin{array}{l}\text { Start sample } \\ \text { End sample }\end{array} & 24.0 & 0840 \\ & & 24.0 & 0905 \\ 2.3 \mathrm{~m} & \text { Start sample } & 27.0 & 0840 \\ & \text { End sample } & 20.5 & 0905\end{array}$


TABLE B-3. Continued

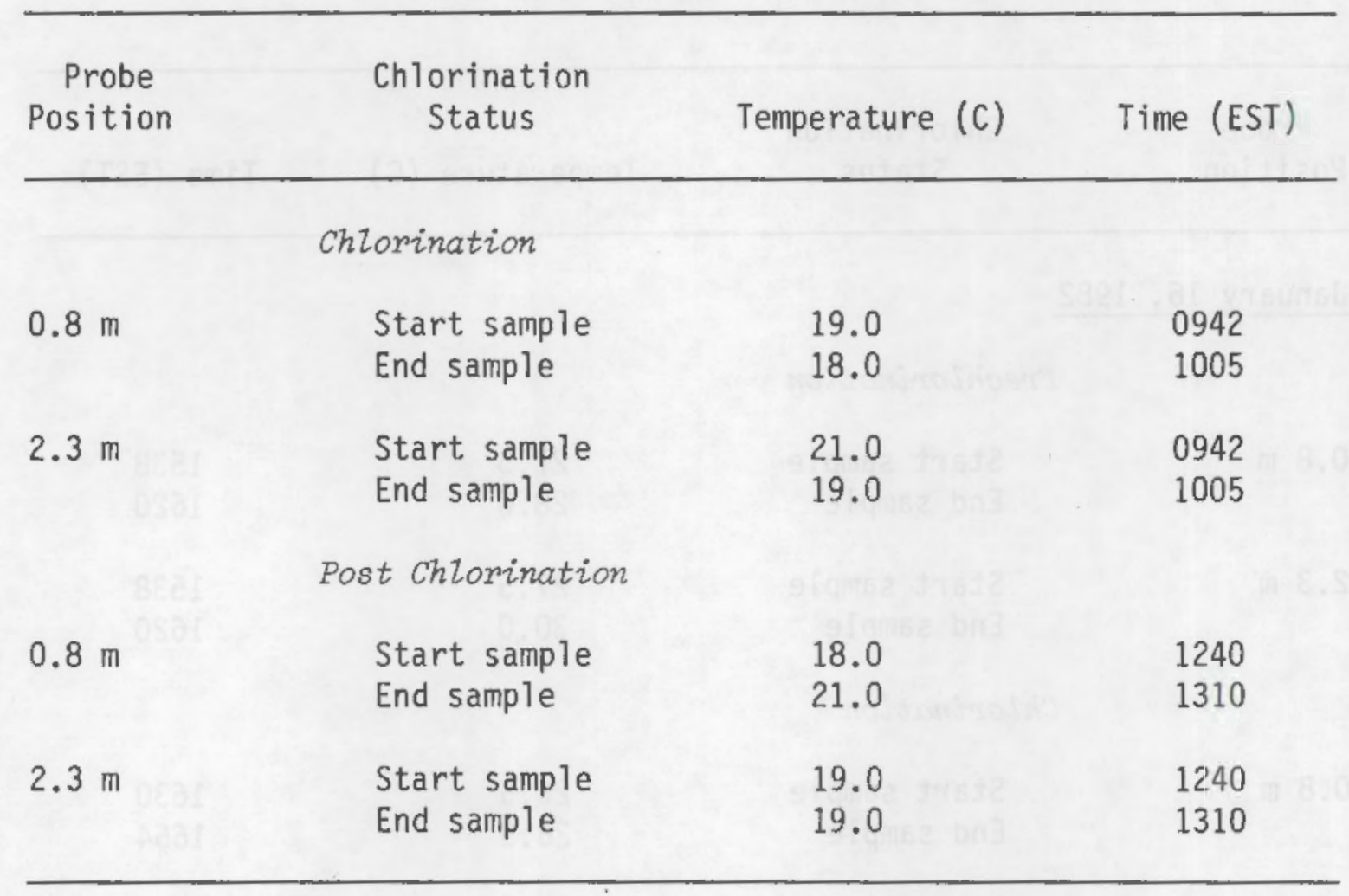


TABLE B-4. Total Residual Chlorine (TRO) Measurements From the Top of the Cooling Tower at Edwin Hatch Power Plant Collected During Vapor Sampling

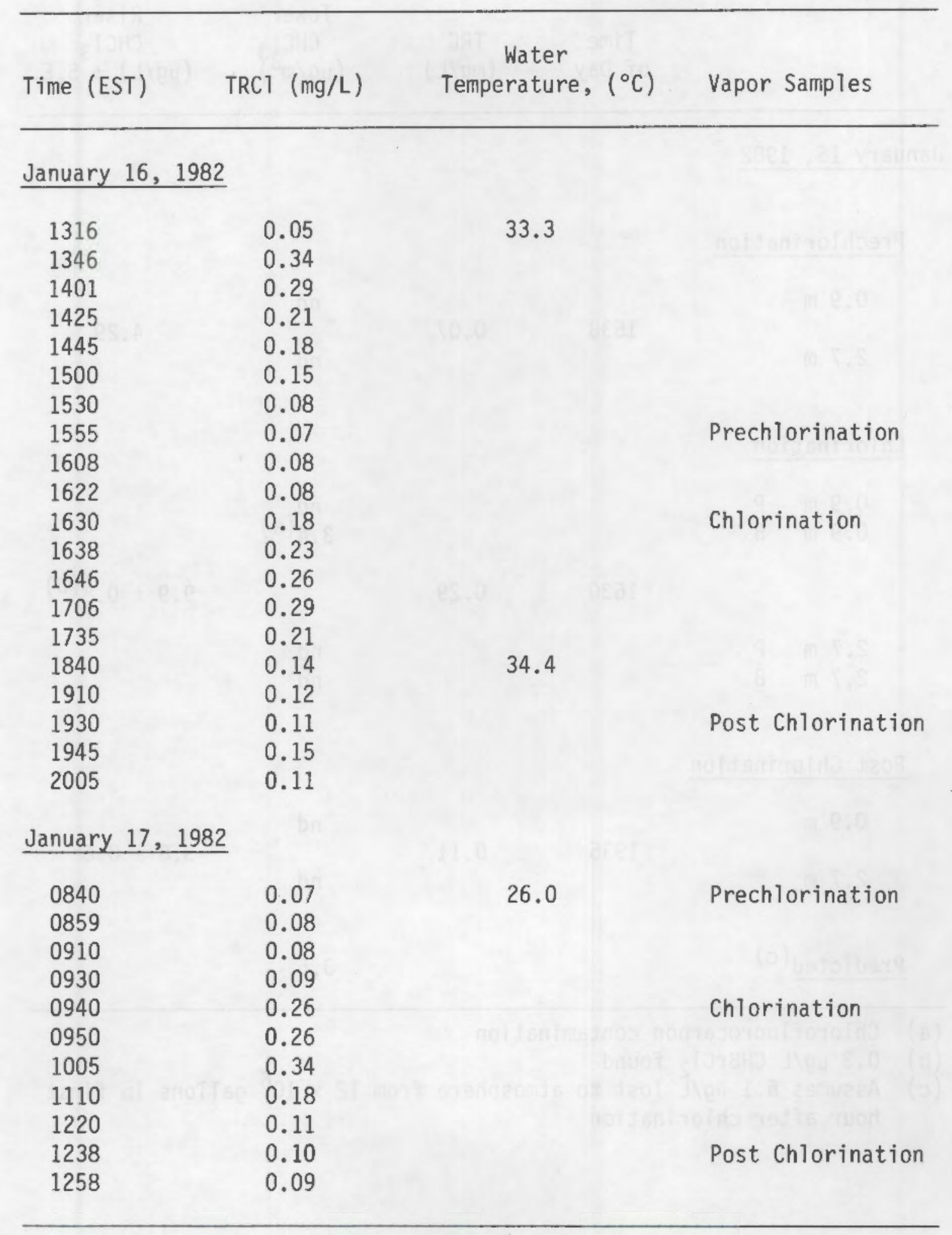


TABLE B-5. Analysis of Cooling Tower Water and Atmospheric Exhaust for Volatile Organohalogens -- Plant Hatch

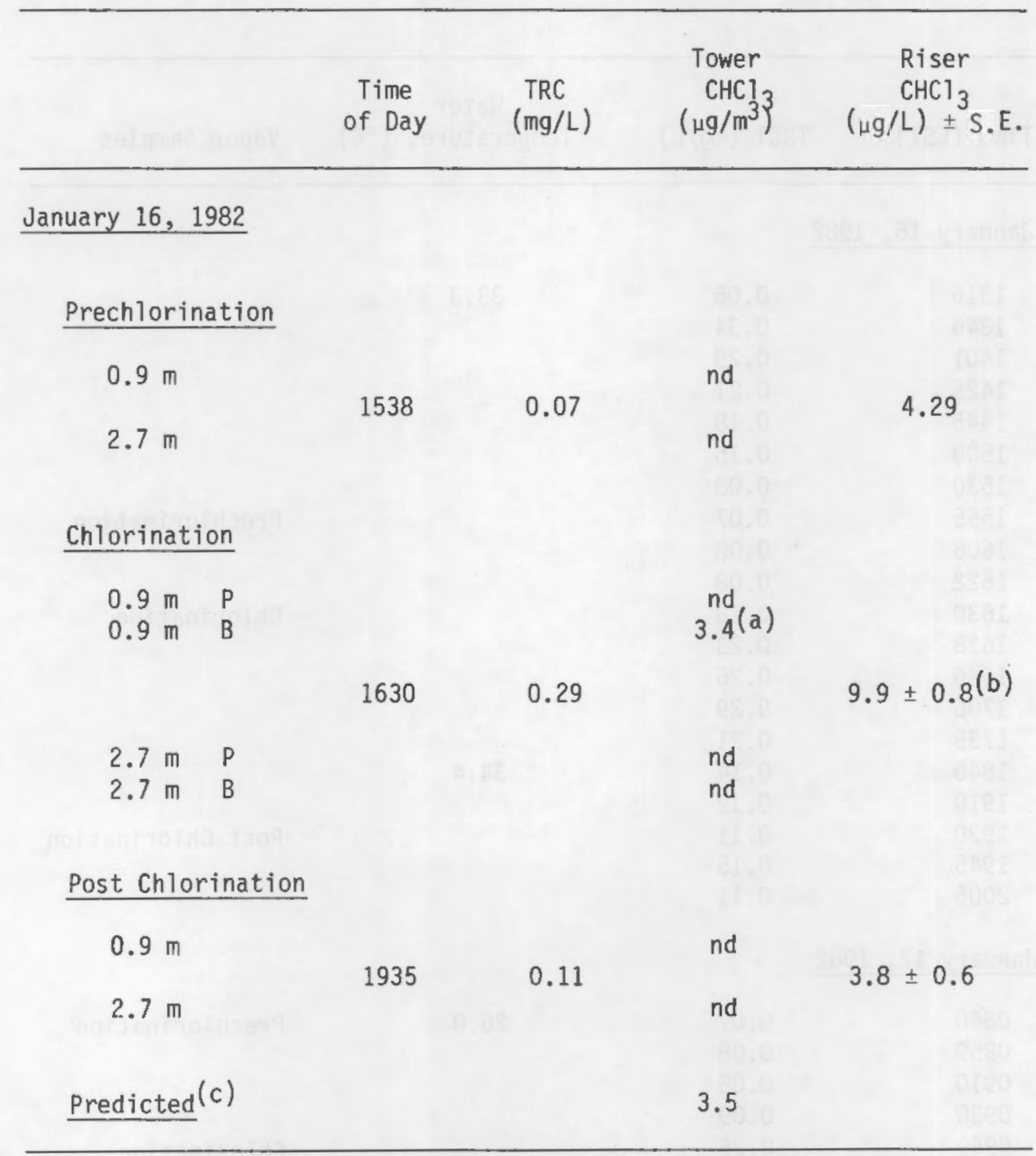

(a) Chlorofluorocarbon contamination

(b) $0.3 \mu \mathrm{g} / \mathrm{L} \mathrm{CHBrCl}_{2}$ found

(c) Assumes $6.1 \mu \mathrm{g} / \mathrm{L}$ lost to atmosphere from $12 \times 10^{6}$ gallons in first hour after chlorination 
TABLE B-5. (Continued)

\begin{tabular}{|c|c|c|c|c|}
\hline & $\begin{array}{l}\text { Time } \\
\text { of Day }\end{array}$ & $\begin{array}{c}\text { TRC } \\
(\mathrm{mg} / \mathrm{L})\end{array}$ & $\begin{array}{c}\text { Tower } \\
\mathrm{CHCl}_{3} \\
\left(\mu \mathrm{g} / \mathrm{m}^{3}\right)^{3}\end{array}$ & $\begin{array}{c}\text { Riser } \\
\mathrm{CHCl}_{3} \\
(\mu \mathrm{g} / \mathrm{L}) \pm \text { S.E. }\end{array}$ \\
\hline \multicolumn{5}{|c|}{ January 17,1982} \\
\hline \multicolumn{5}{|c|}{ Prechlorination } \\
\hline $\begin{array}{l}0.9 \mathrm{~m} \\
2.7 \mathrm{~m}\end{array}$ & 0842 & 0.09 & $\begin{array}{l}\text { nd } \\
\text { nd }\end{array}$ & $4.6 \pm 0.3$ \\
\hline
\end{tabular}

Chlorination
$0.9 \mathrm{~m} \quad \mathrm{P}$
$0.9 \mathrm{~m} \quad B$
2.2
nd
0942
0.34
$13.8 \pm 0.8^{(b)}$

$2.7 \mathrm{~m} \quad \mathrm{P}$

$2.7 \mathrm{~m} \quad \mathrm{~B}$

$0.87(a)$

12.8-32.2

\section{Post Chlorination}
$0.9 \mathrm{~m}$
1246
0.09
nd
$2.7 \mathrm{~m}$
nd
$6.6 \pm 0.1$

Predicted $(c)$

4.1

(a) Chlorofluorocarbon contamination

(b) $0.5 \pm 0.1 \mu \mathrm{g} / \mathrm{L} \mathrm{CHBrCl}_{2}$ found

(c) Assumes $7.2 \mathrm{\mu g} / \mathrm{L}$ lost to atmosphere from $12 \times 10^{6}$ gallons in first hour after chlorination 

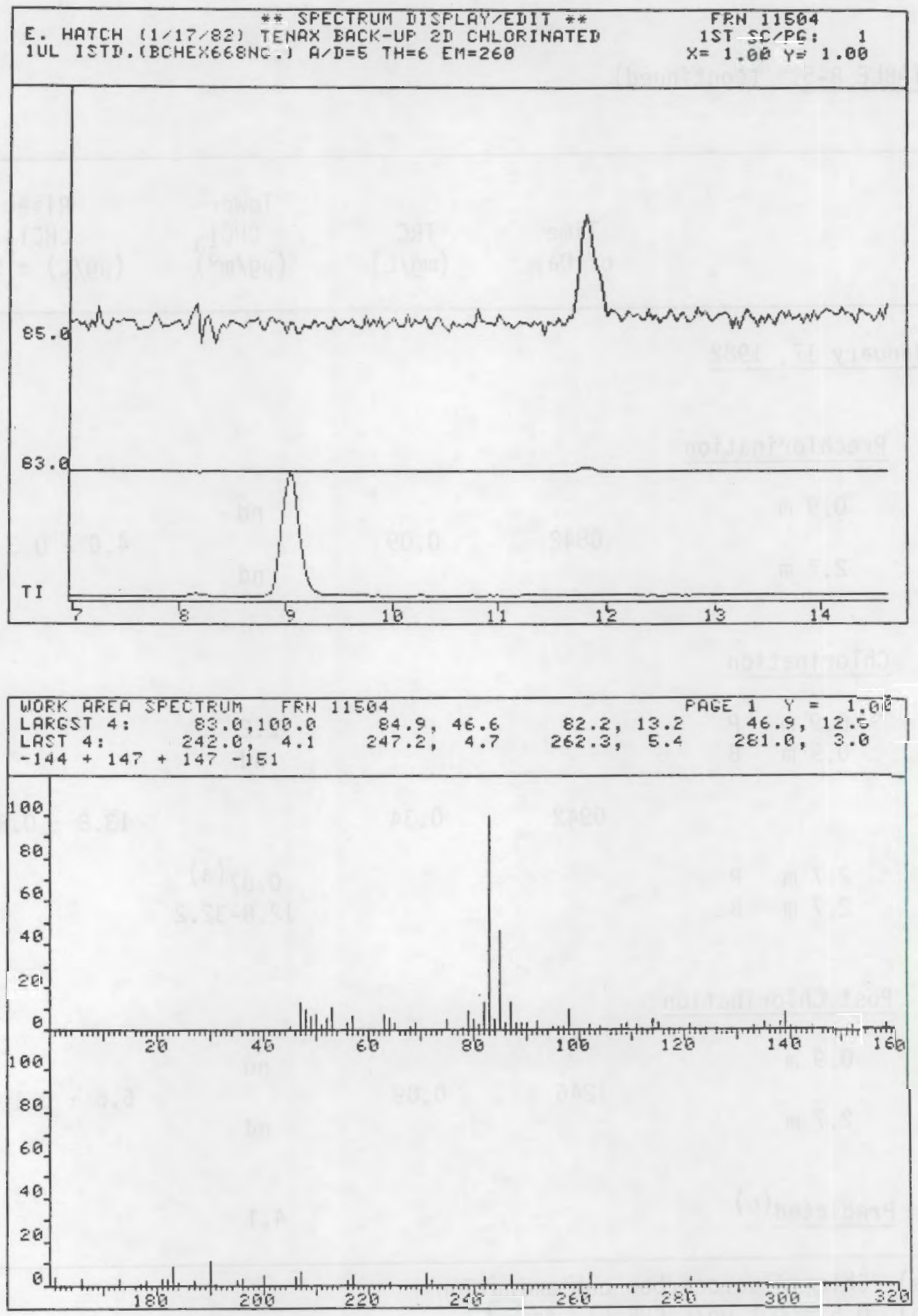

FIGURE B.7. GC/MS Analysis of Chloroform From Cooling Tower Exhaust 

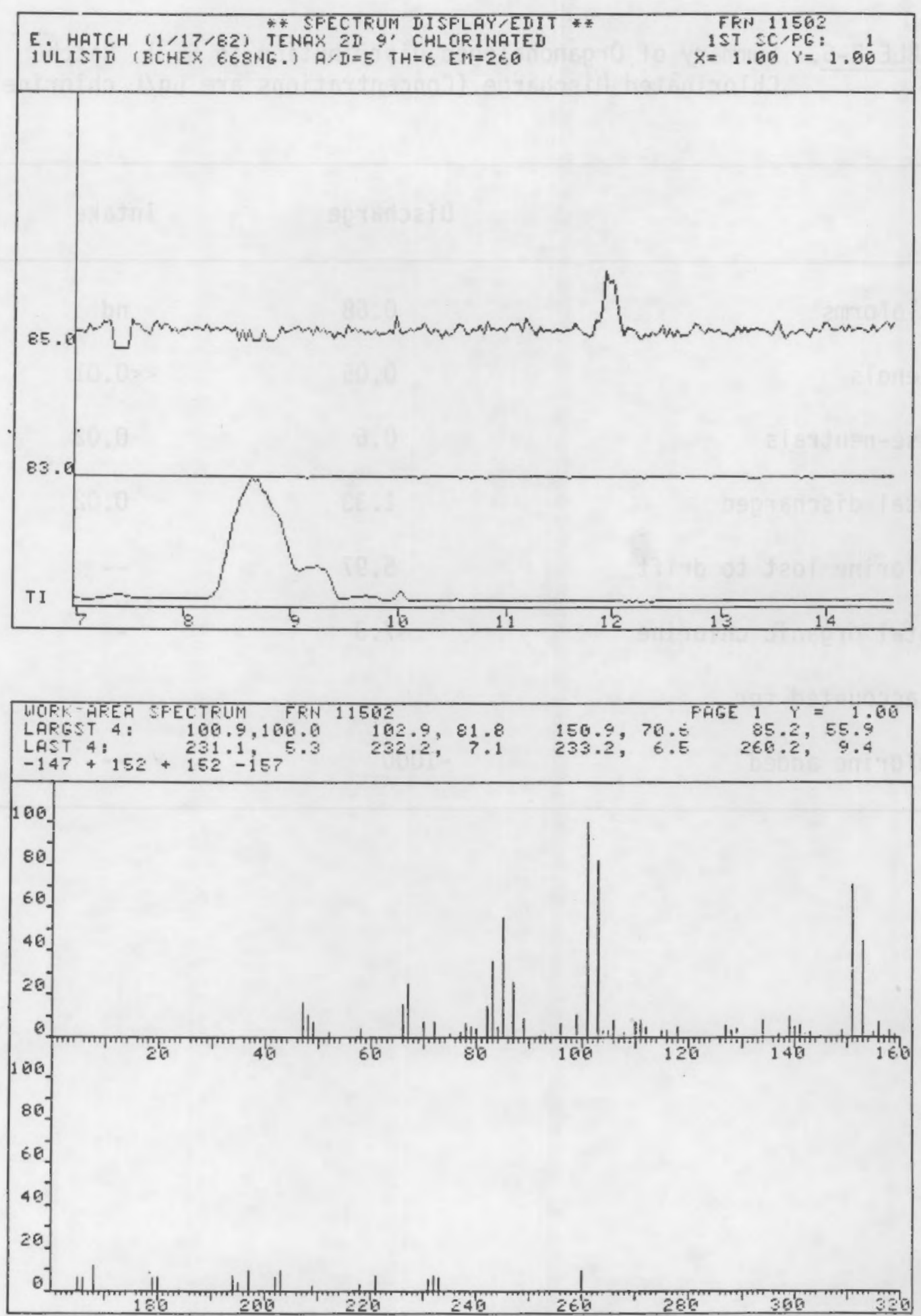

FIGURE B.8. GC/MS Analysis of Chloroform From Cooling Tower Exhaust Showing Contaminating Spectra From Chlorofluorocarbon 
TABLE B-6. Summary of Organohalogen Distribution in E. I. Hatch Chlorinated Discharge (Concentrations are $\mu \mathrm{g} / \mathrm{L}$ chlorine)

\begin{tabular}{lcc}
\hline & Discharge & Intake \\
\hline Haloforms & 0.68 & nd \\
Phenols & 0.05 & $<<0.01$ \\
Base-neutrals & 0.6 & 0.02 \\
Total discharged & 1.33 & 0.02 \\
Chlorine lost to drift & 5.97 & - \\
Total organic chlorine & 7.3 & - \\
accounted for & $\sim 1000$ & \\
\hline
\end{tabular}




\section{APPENDIX C \\ TOTAL ION CHROMATOGRAM AND SPECTRA OF DERIVATIZED HALOGENATED PHENOLS FROM TROJAN COOLING TOWER}

The following pages show the analysis conducted on the gas chromatograph/mass spectrometer for the halogenated phenols in the Trojan cooling tower basin. The phenols are isolated as their acetates; therefore 42 mass units above the prominant peaks equivalent to the molecular weight of the phenol is the molecular ion halogen isotope cluster of the phenol acetate. This repetition of the halogen isotope cluster 42 units higher is a diagnostic test for the present of the derivatized phenol acetate. The pattern of the isotope clusters are diagnostic for determining the number and types of halogen atoms on the phenol aromatic ring. 

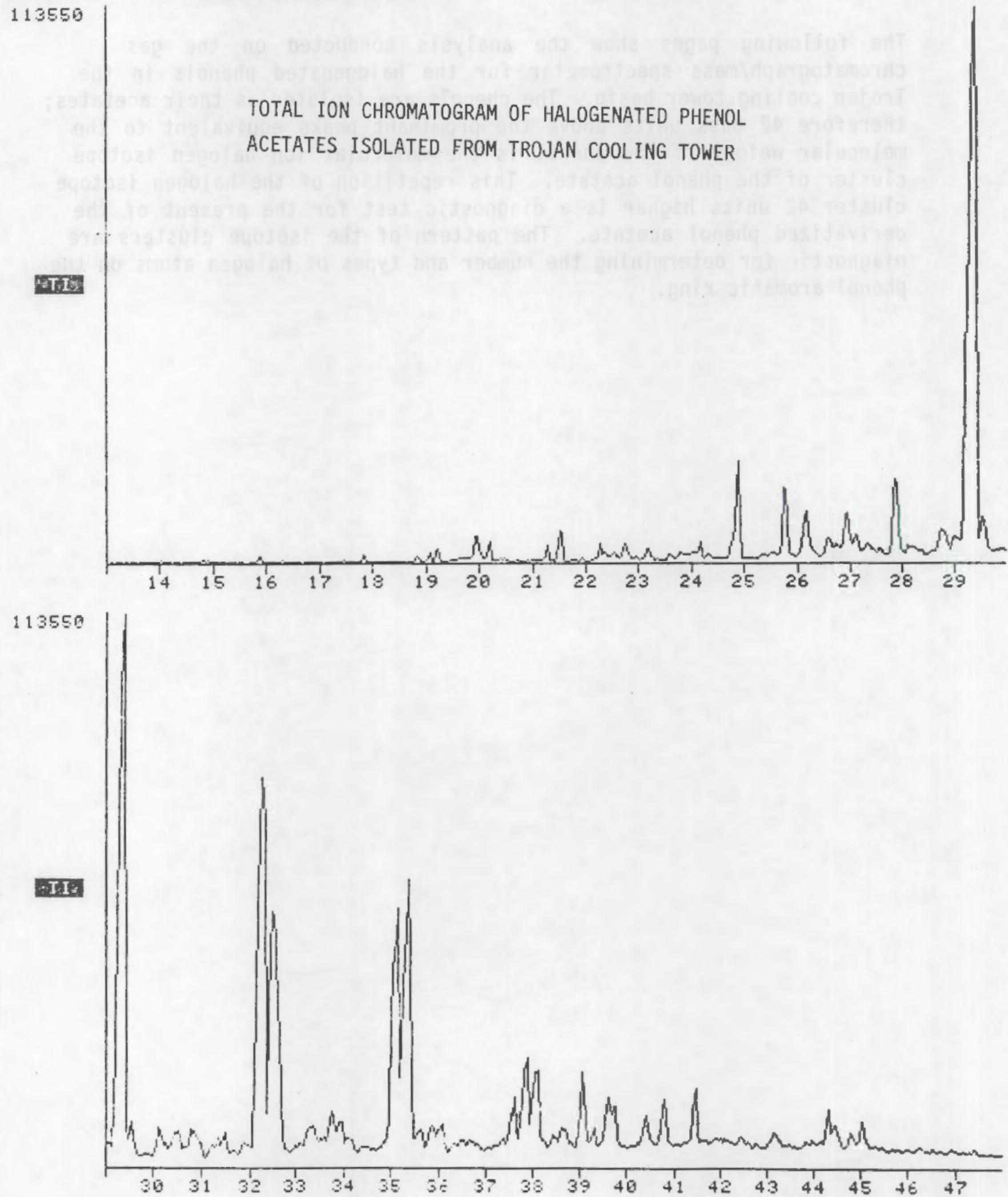
TFOU AI: FHEHOLS XAI 3 A TOHEF

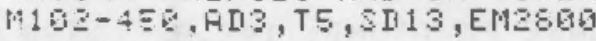

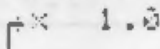

ERH 8002, PRH 8

2492 SCANS $\quad 403$ SLAH, 16.02 MINS MAS: FAHIGE: $161.9,449.3$ TOTAL REUND = 9734246 .

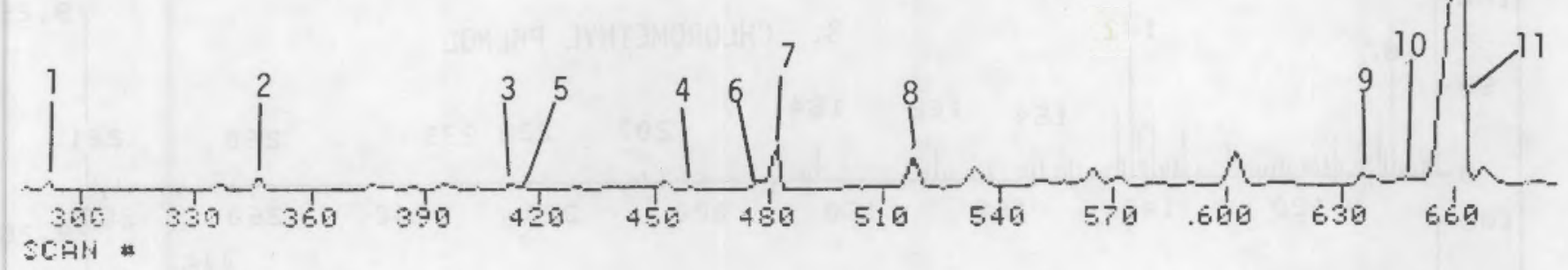
Sctill *

* 282 FET. TIME: 20.18 TOT AEUHD= 4792. EASE FK/AQUNI: 128.1 2557.

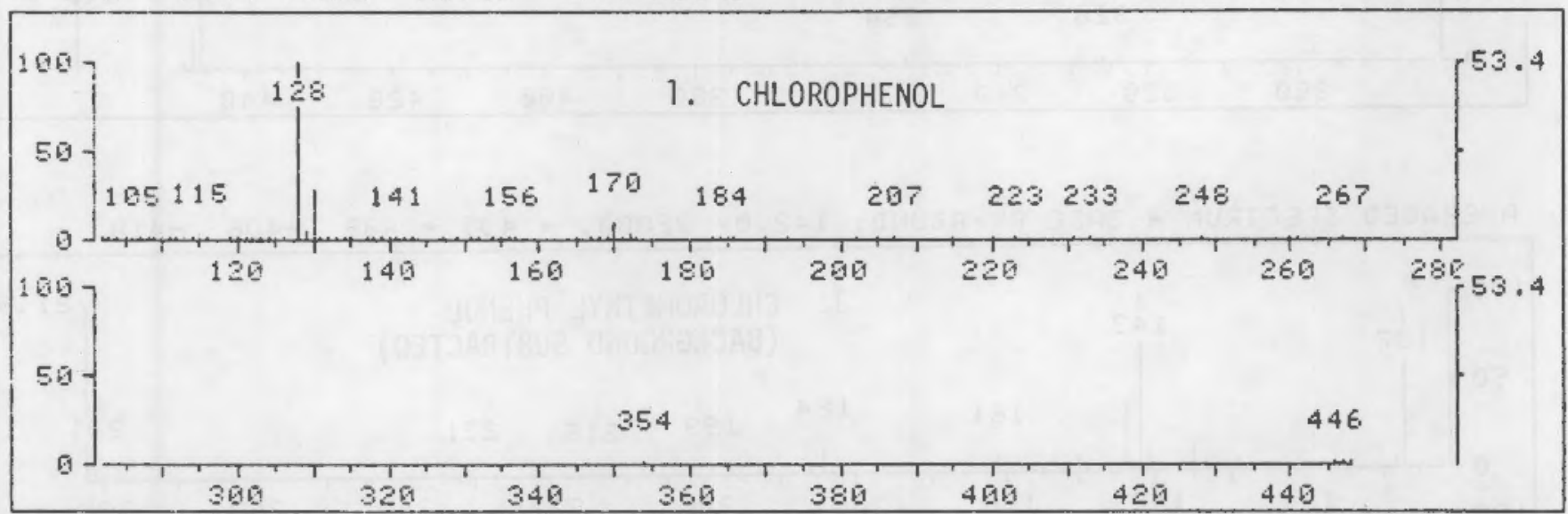

* 346 RET. TIME: 21.52 TOT AEUND= 6778. EASE FK/AEUND: 128.0 . 388 .

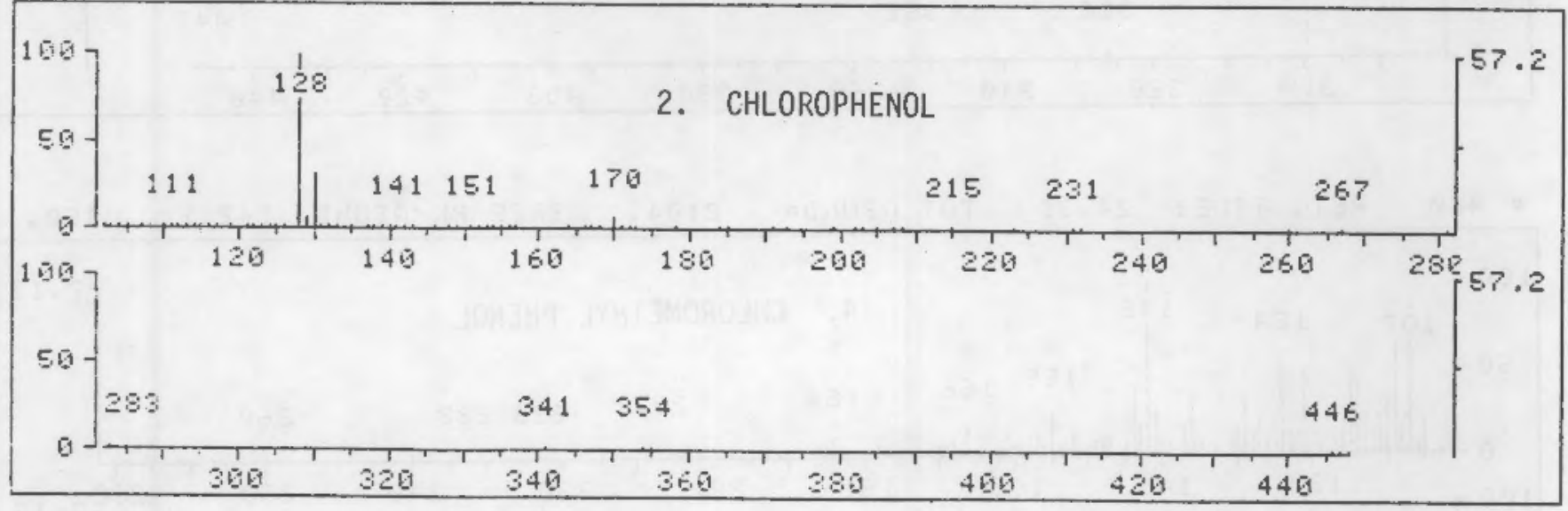



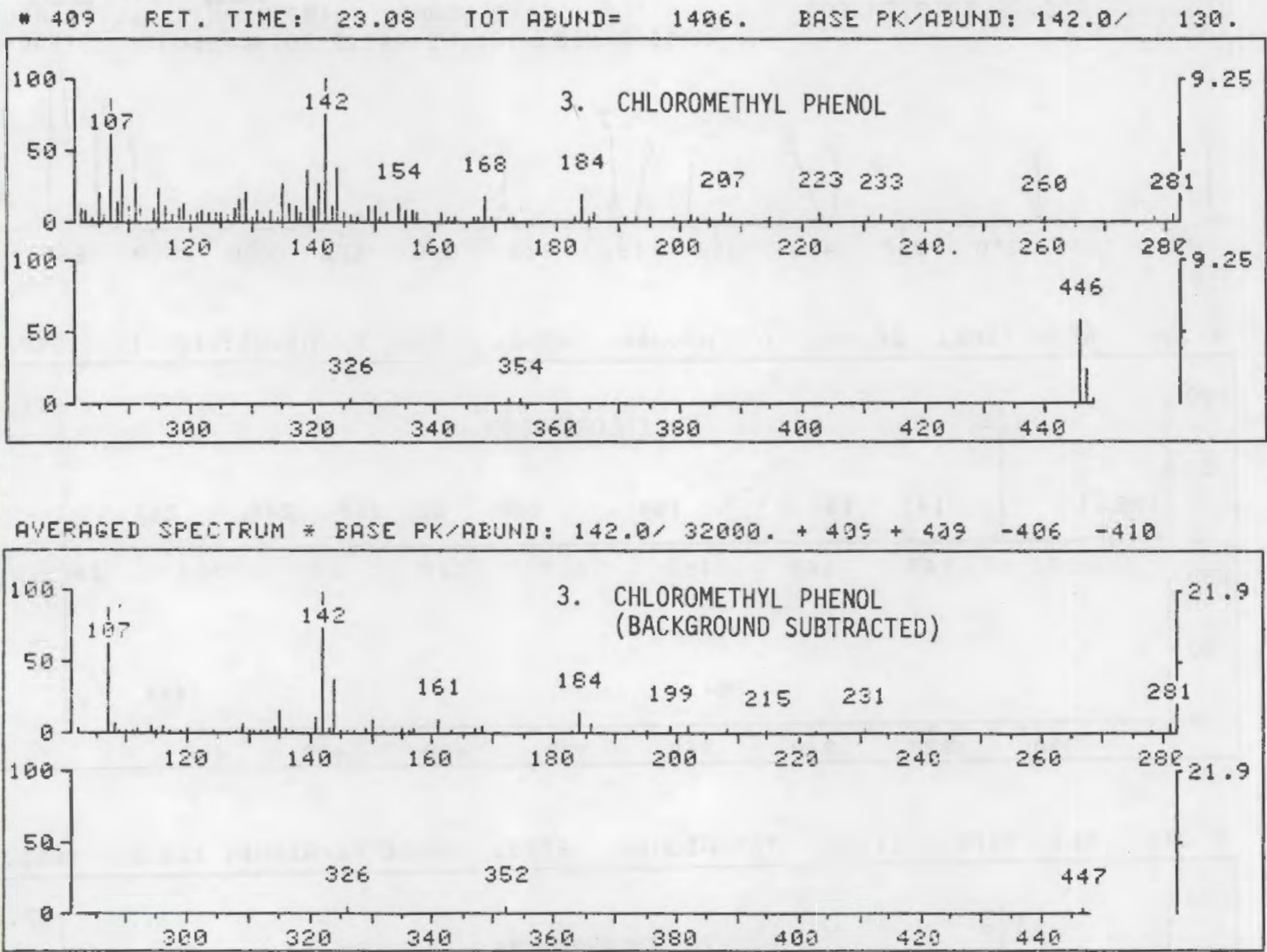

* 4ED RET. TIME: 24.35 TOT FEUND= 2104. EASE FK/AEUHD: 142.1/ 15Q.

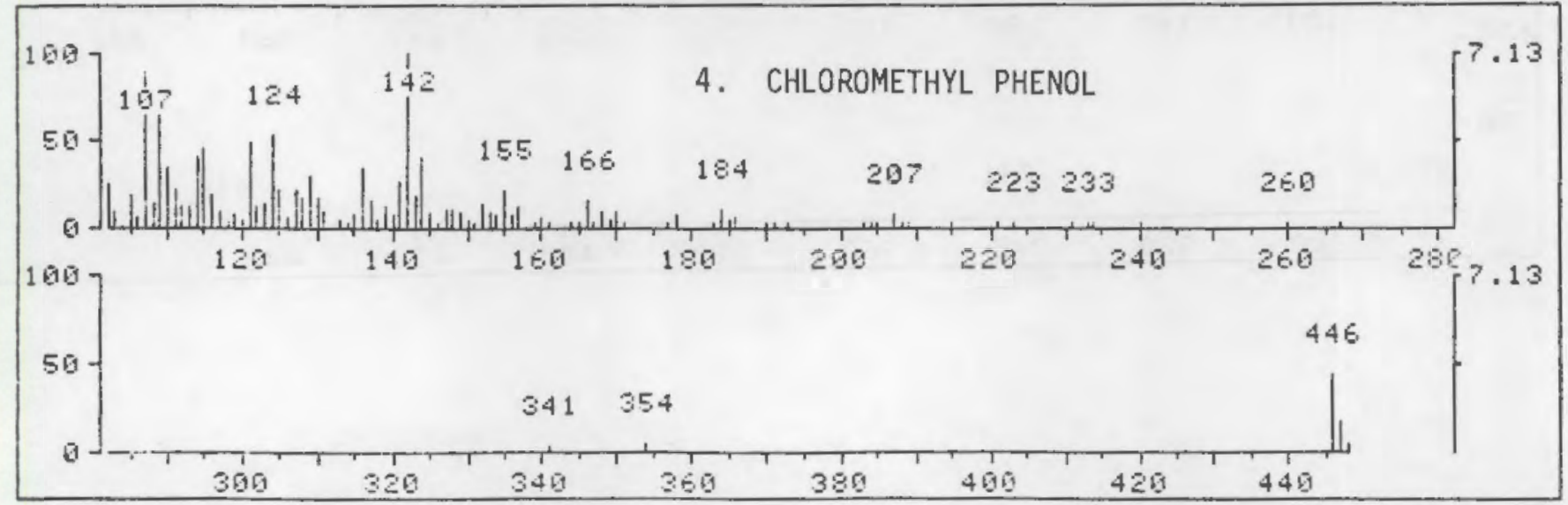


* 413 FET. TIME: 23.18 TOT AEUNII= 3228. RRSE FK/F3UND: 172.6/ 863.

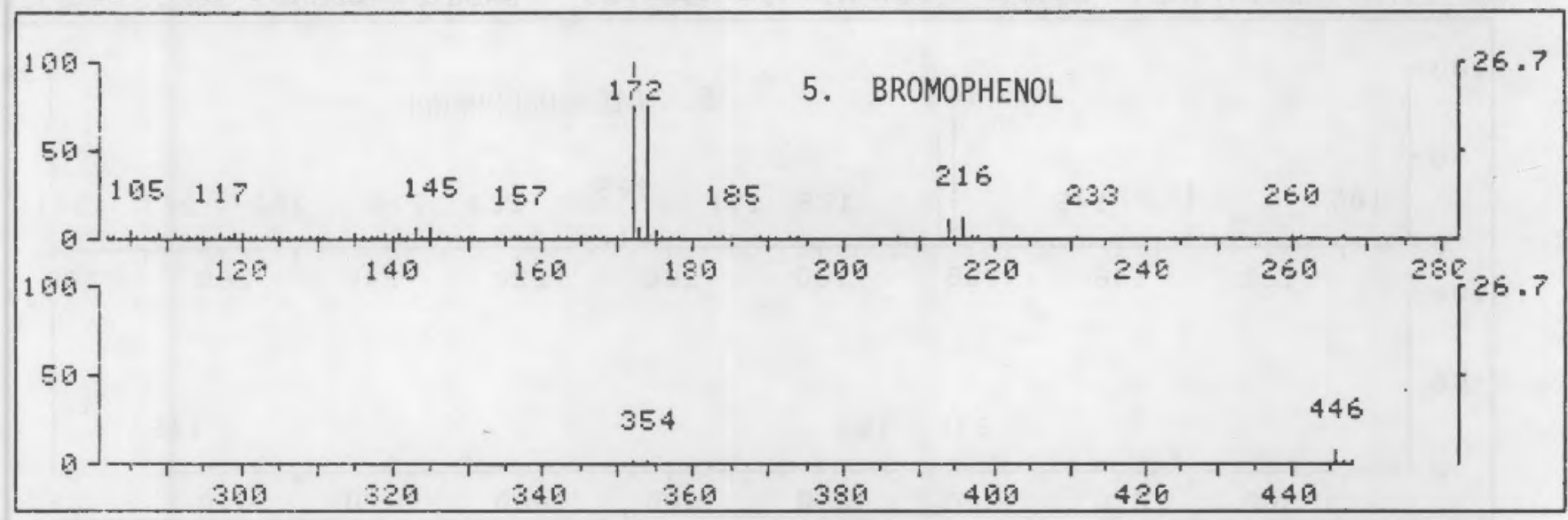

* 476 RET. TIME: 24.75 TOT AEUND= 3066. EASE PK/FEUND: $172 . B /$ 405.

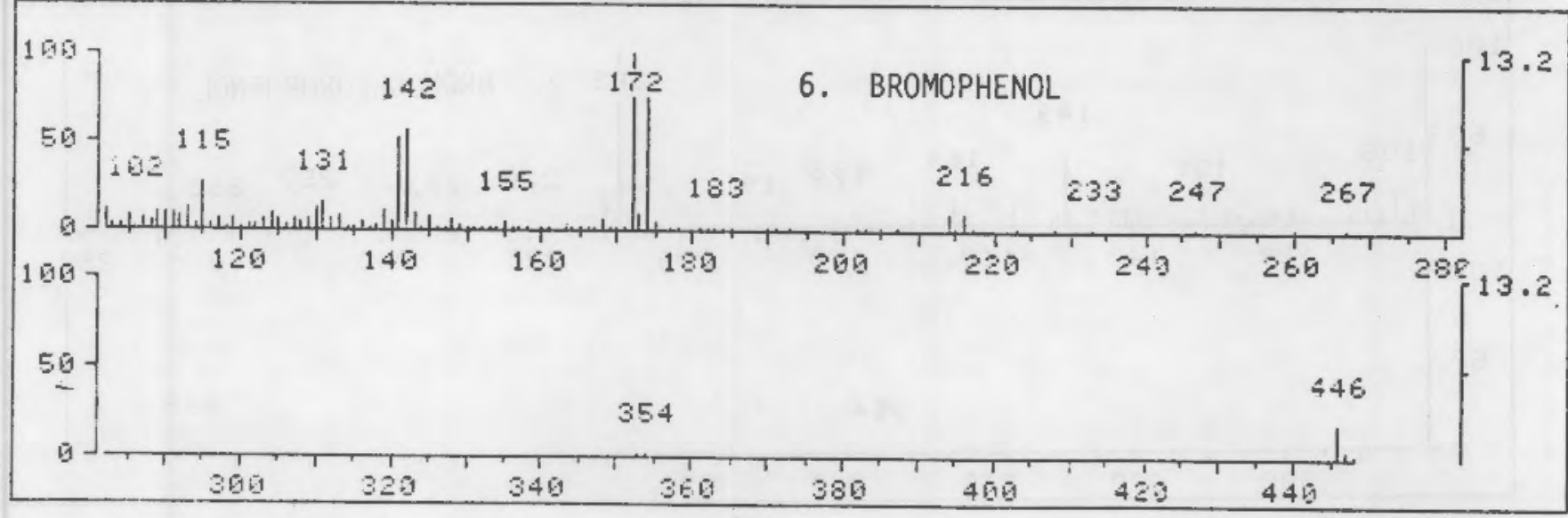

\# 482 RET. TIME: 24.90 TOT AEUHD= 21519. EASE FK/ABUND: 162.0/ 7431.

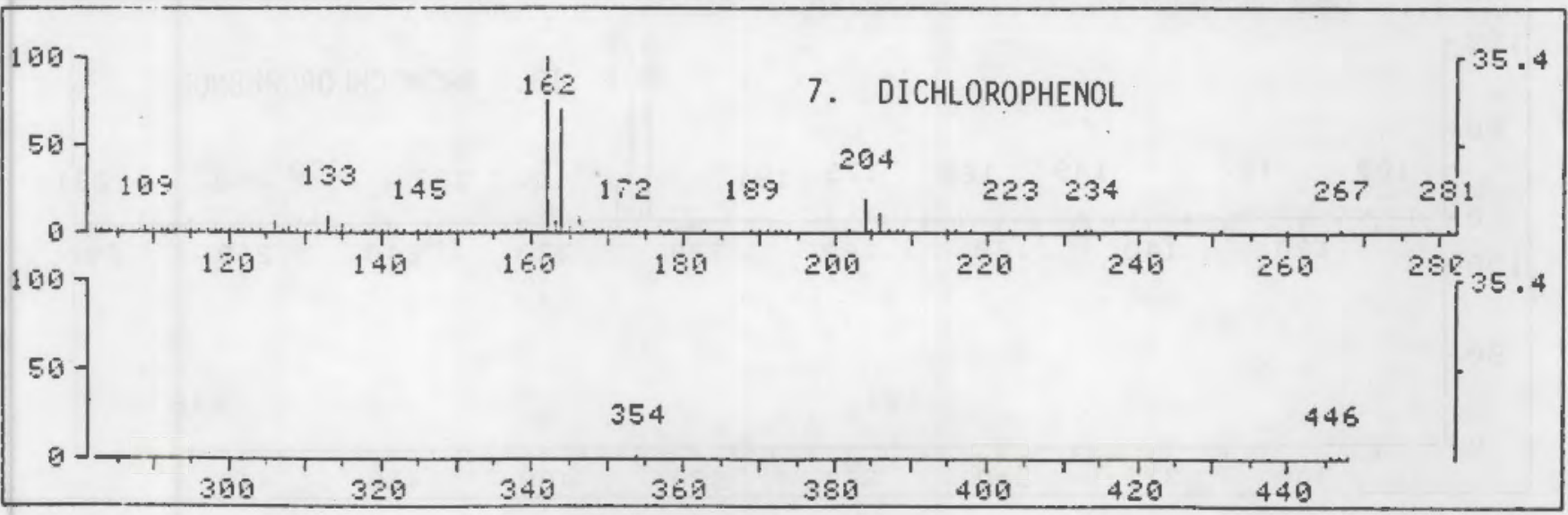


- 517 RET. TIME: 25.77 TOT AEUNI= 15478. BASE FK/ABUNI: 162.0/ 5326.

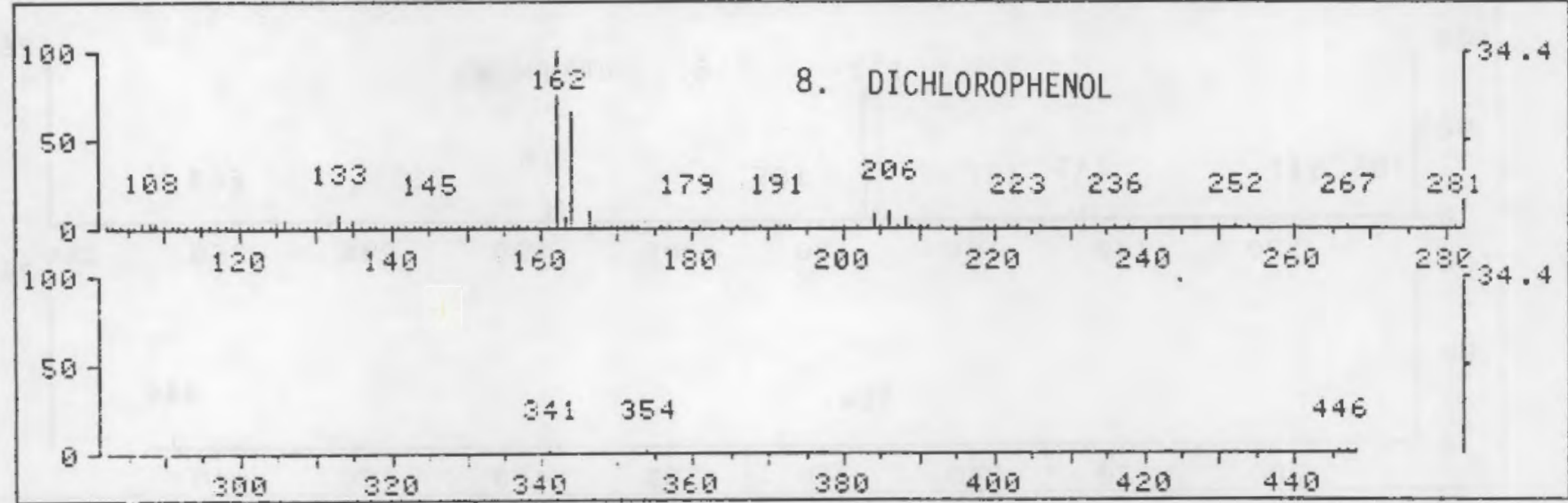

\# 635 RET. TIHE: 28.79 TOT REUND= 6249. BASE PK/ABUNI: 297.9/ 1067.

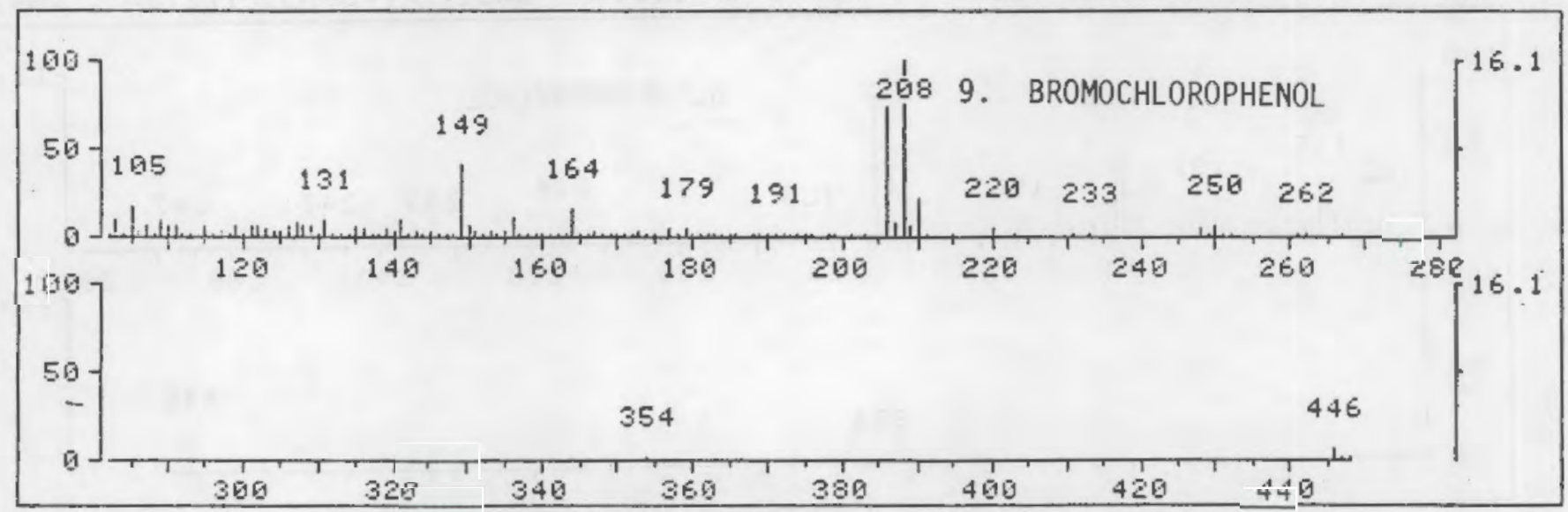

\# 647 RET. TIME: 29.09 TOT ABUND= 5808. BHSE FK/AEUNII: $207.9 / 1342$.

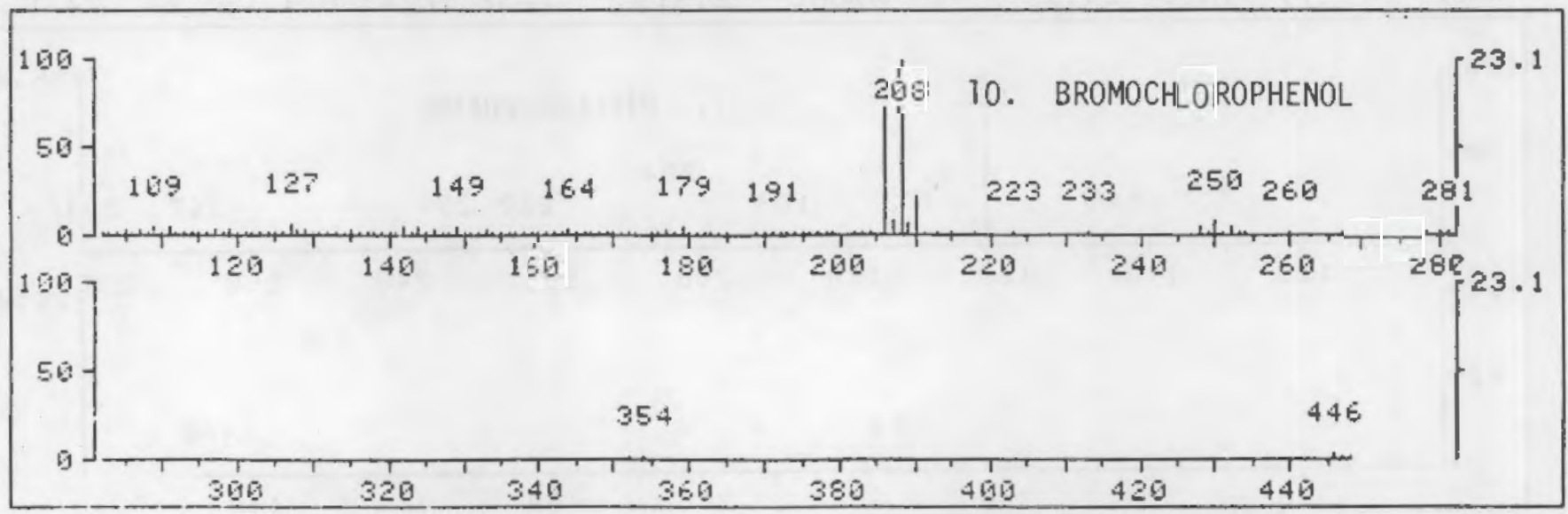


661 FET. TIME: 29.35 TOT AEUNII= 107274. BRSE PK/AEUNI: 196.0 . 26489.

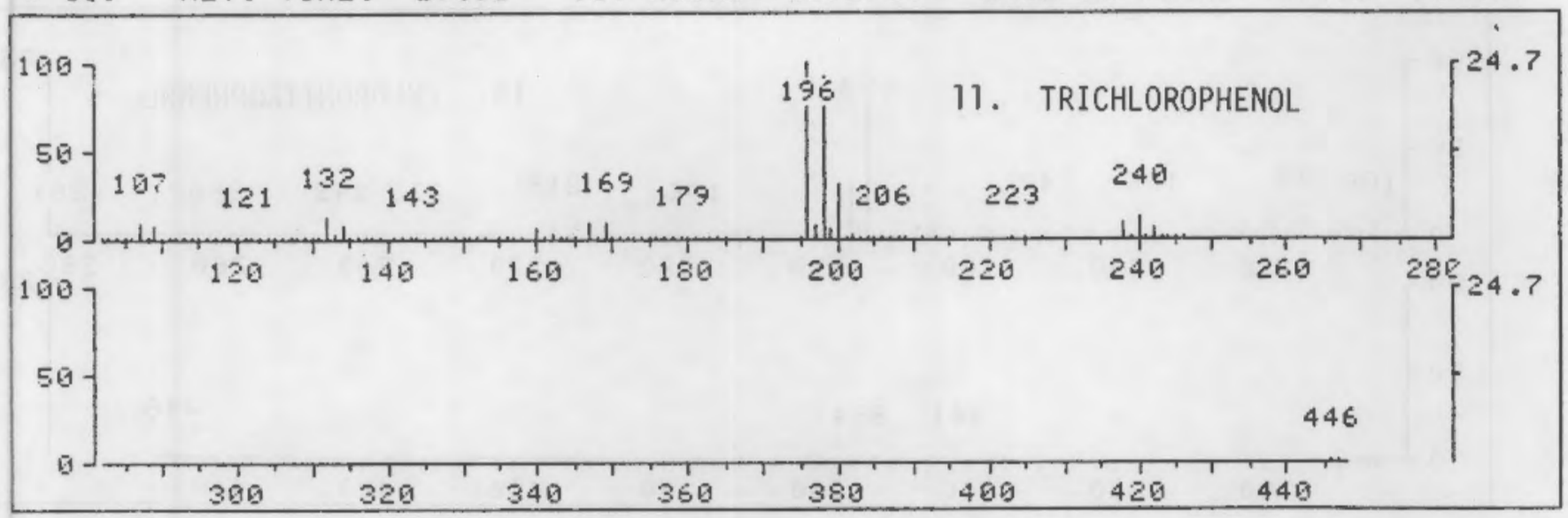

TROJAH FHEHOLS XAD 3 A TOWER 2482 SCAHS ( 351 SERH 8002, CRHA 8
8.80 MINS) $M 102-459$, AD $, T 5, S D 13, E M 2800$ (12) MASS RANEE: $101.6,449.3$ TOTAL ABUND $=9734246$ 16

SCAH

* 705 RET. TIME: 30.45 TOT AEUHD= 7451. EASE FK/ABUND: $173.6 / 1817$.

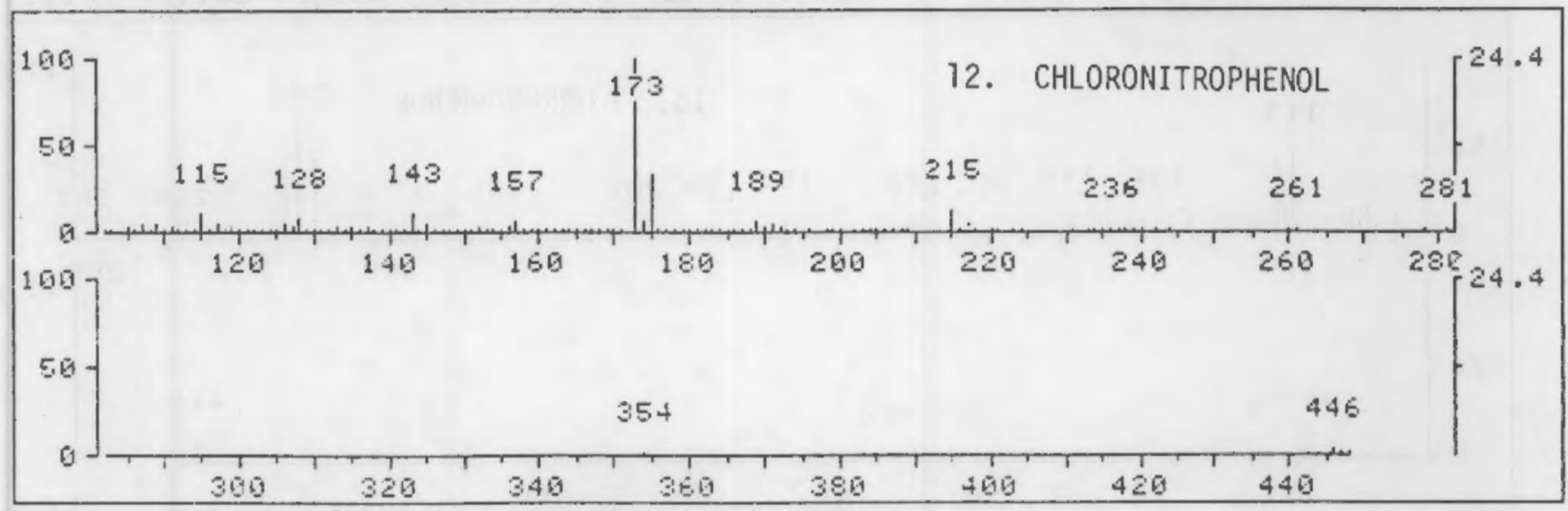




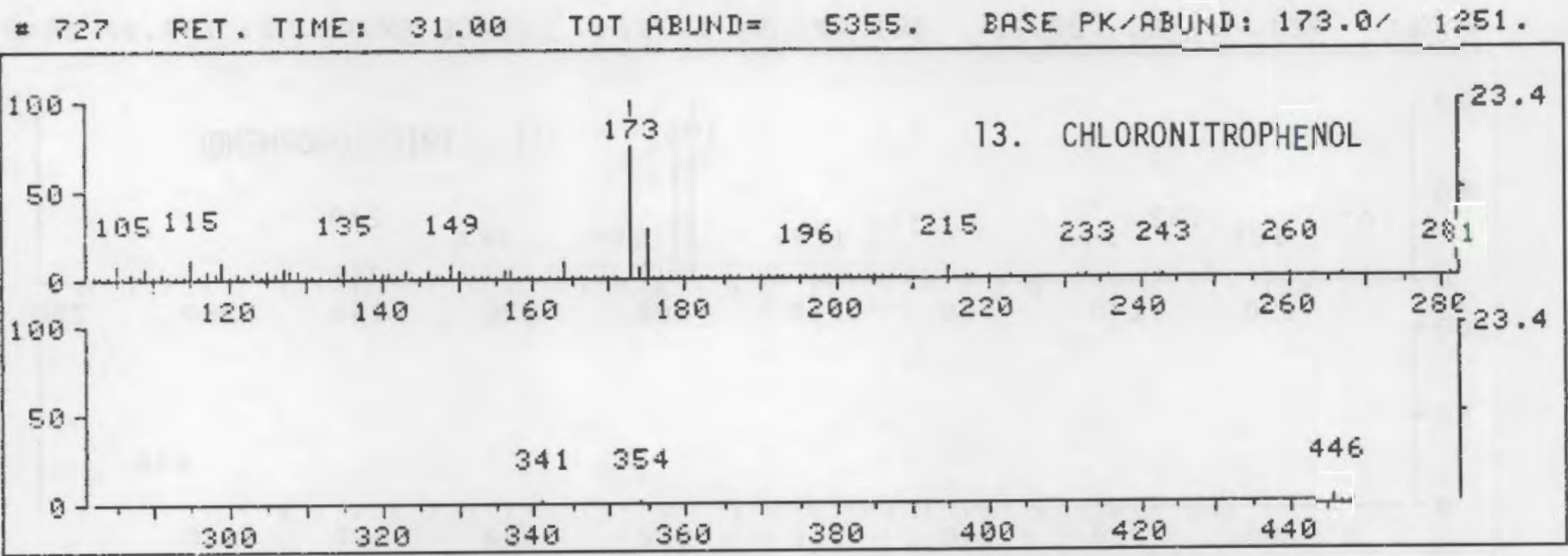

\# 719 RET. TIME: 30.80 TOT ABUND= 823E. BRSE PK/PBUND: $251.9 / 1954$.

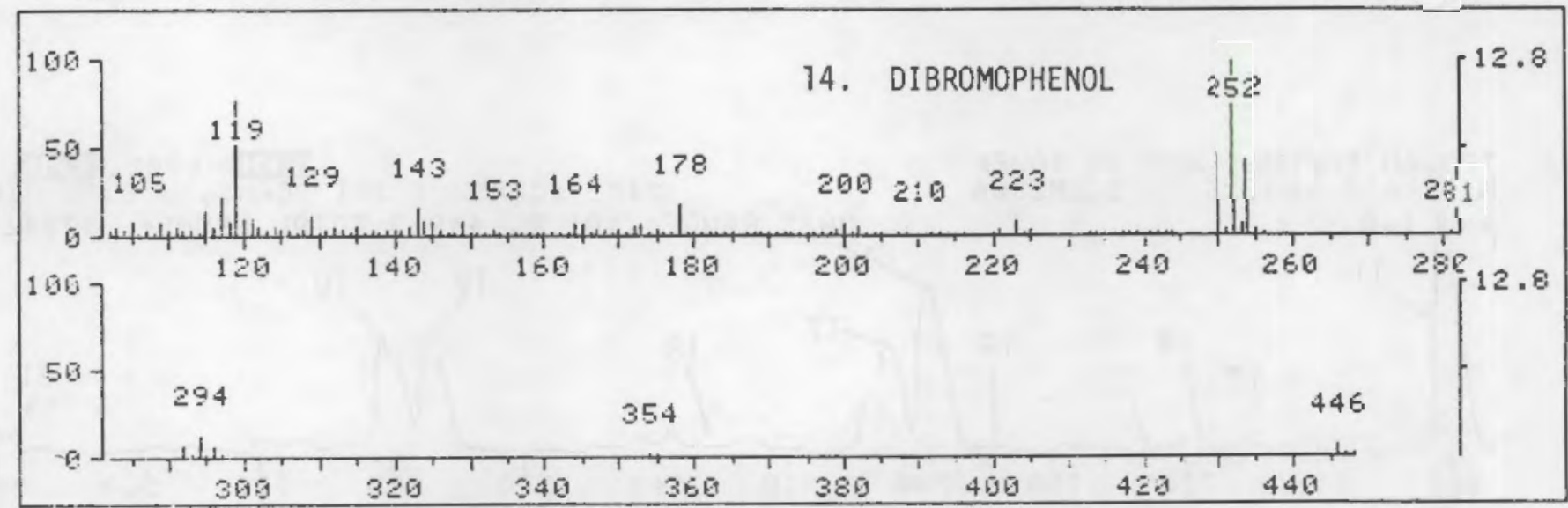

* 7E4 RET. TIME: 31.92 TOT AEUHD= 5577. RASE PK/AEUND: 251.9/ 622.

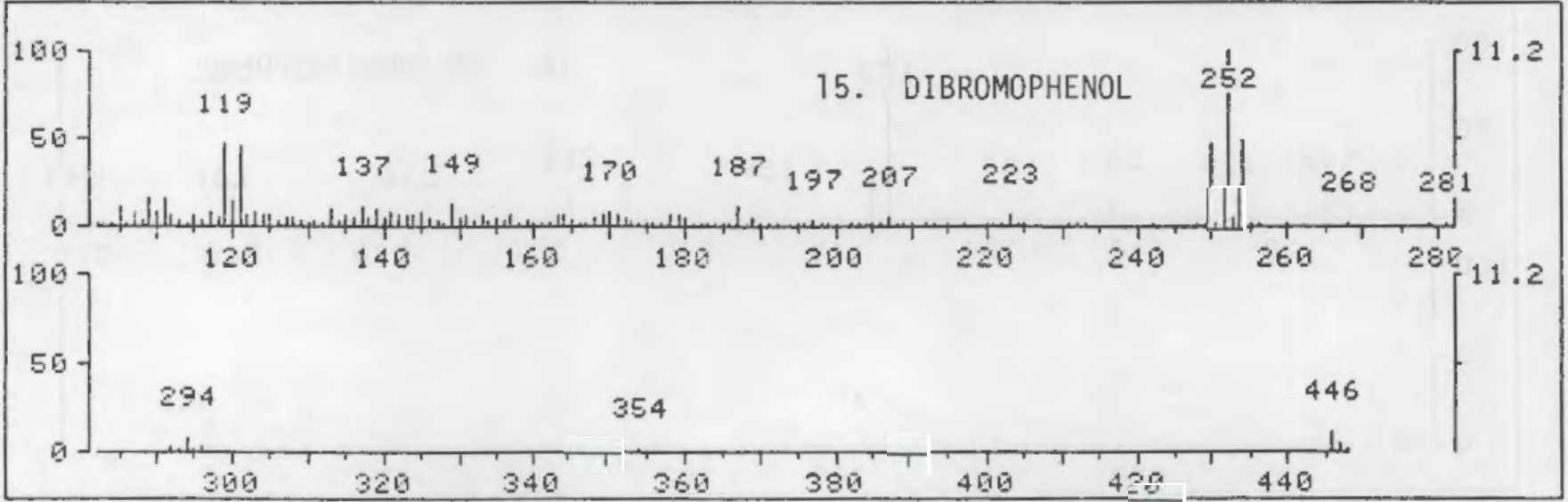


*775 RET. TIME: 32.27 TOT AEUND= 80292. EASE PK/AEUND: 241.9/2B512.

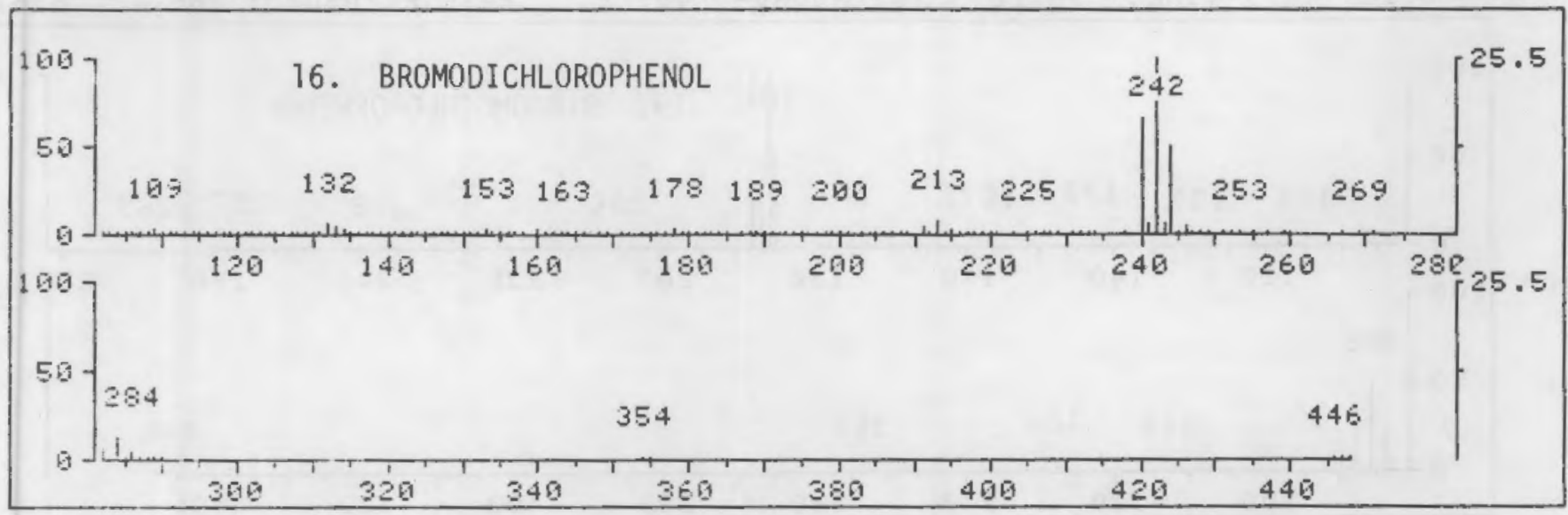

* 7G7 RET. TIME: 32.50 TOT AEUNI= 51922. EASE PK/PBUND: $241.9 / 11871$.

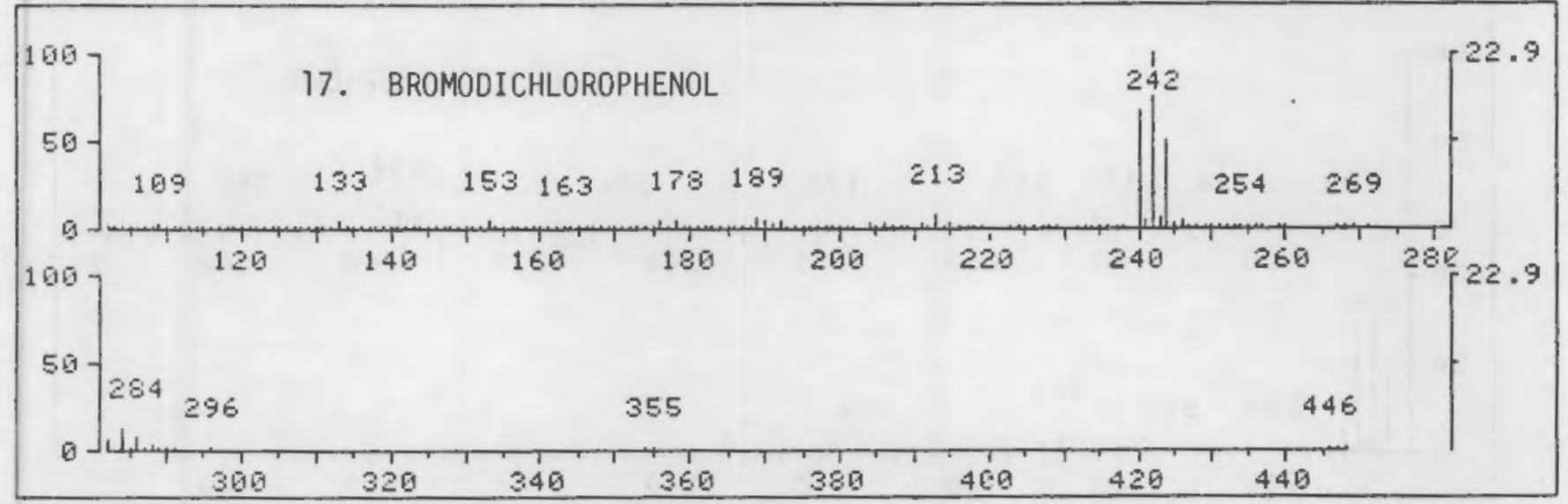

FWERAGED SFECTRUM * BASE PK/AEUND: $188.1 / 32000 .+829+829-832-626$

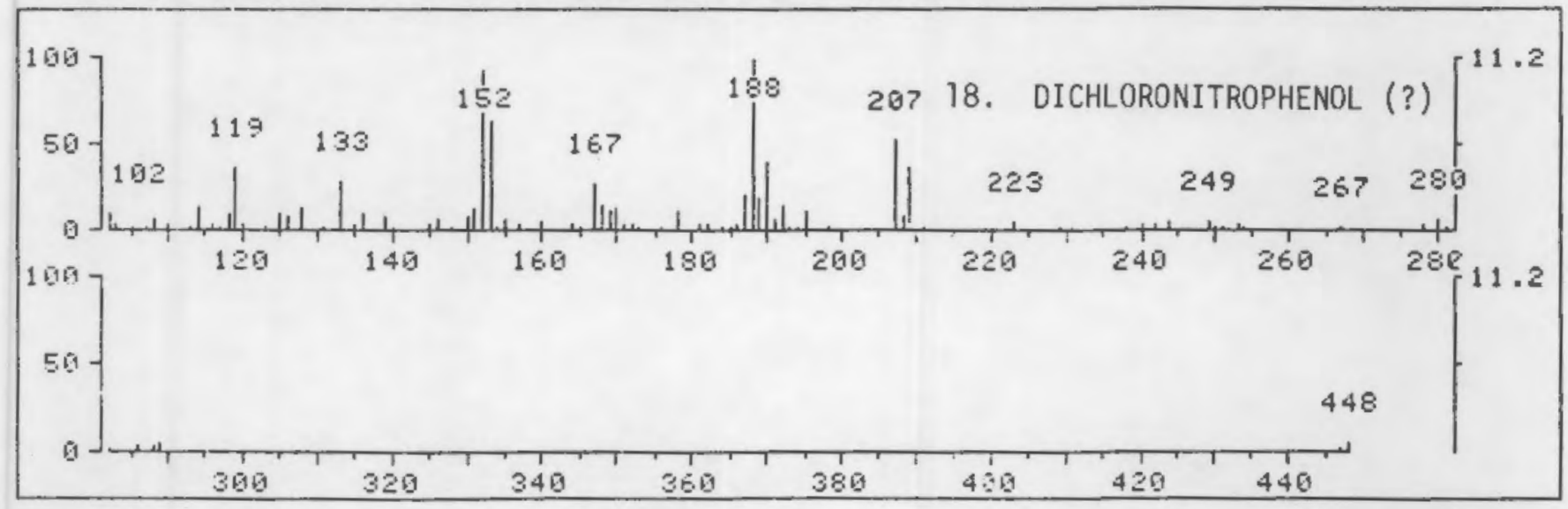


* 891 RET. TIME: 35.10 TOT AEUNI= 45972. EASE PK/ABUND: 186.1/ 8931.

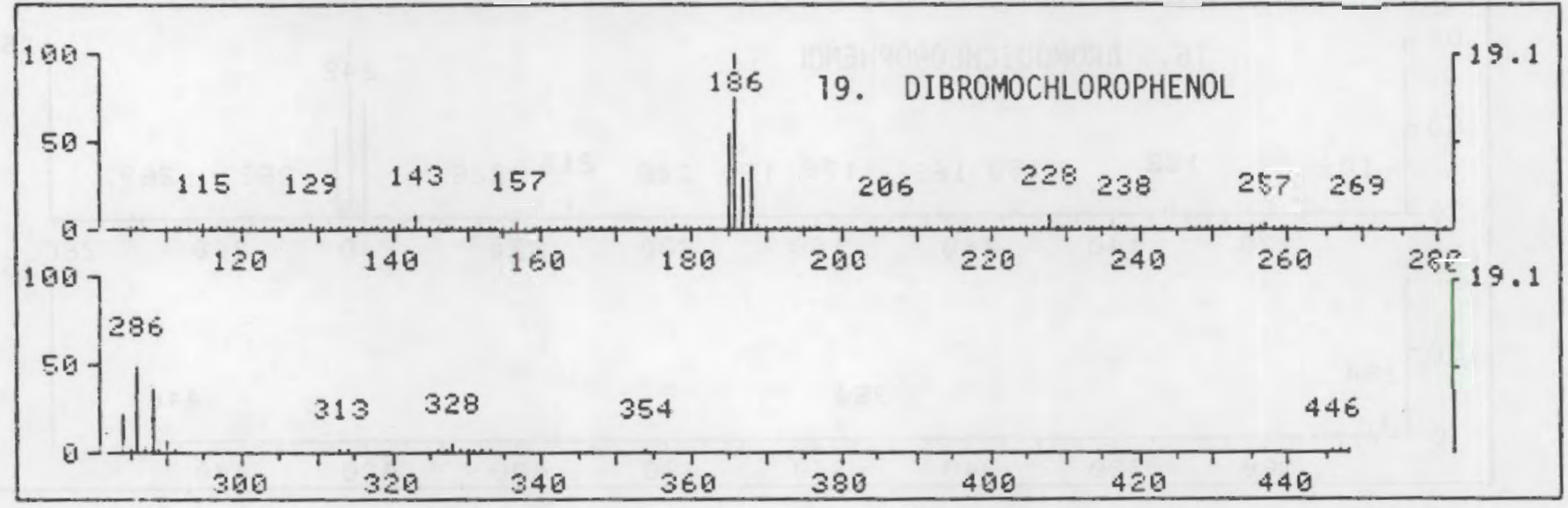

* 981 RET. TIME: 35.35 TOT ABUHD= 48929. BASE PK/ABUND: $285.9 /$ 8885.

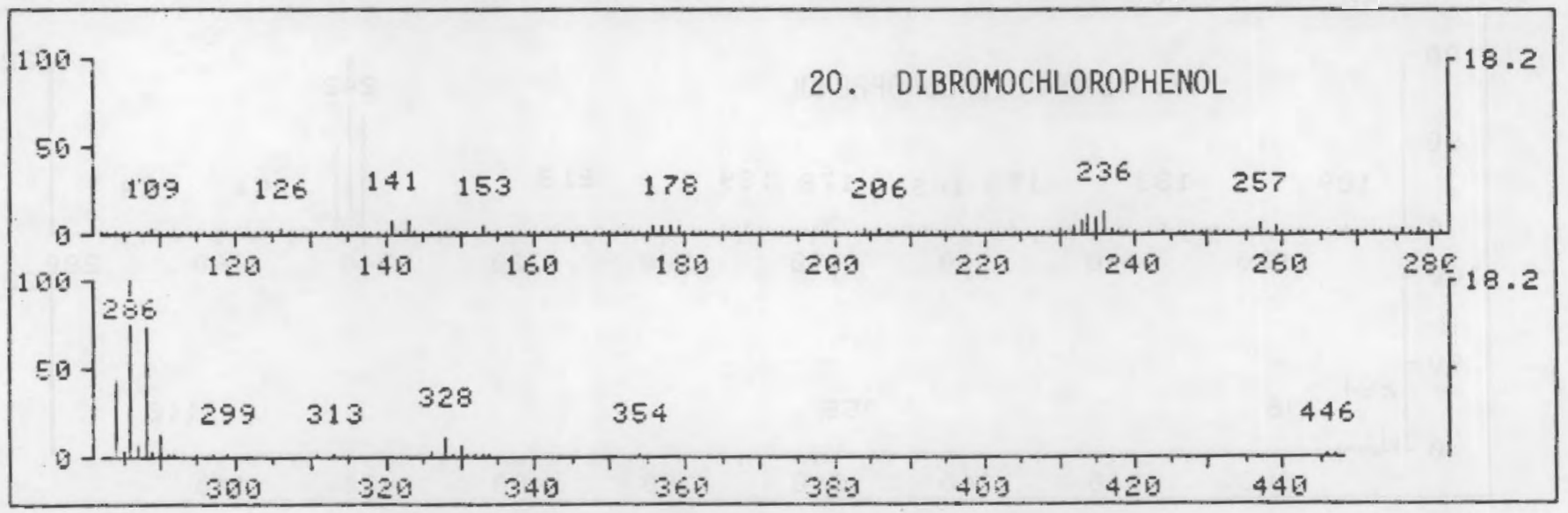


\# 987 RET. TIME: 37.53 TOT AEUHD= 11245. BASE FK/ABUND: $232.0 / 1703$.

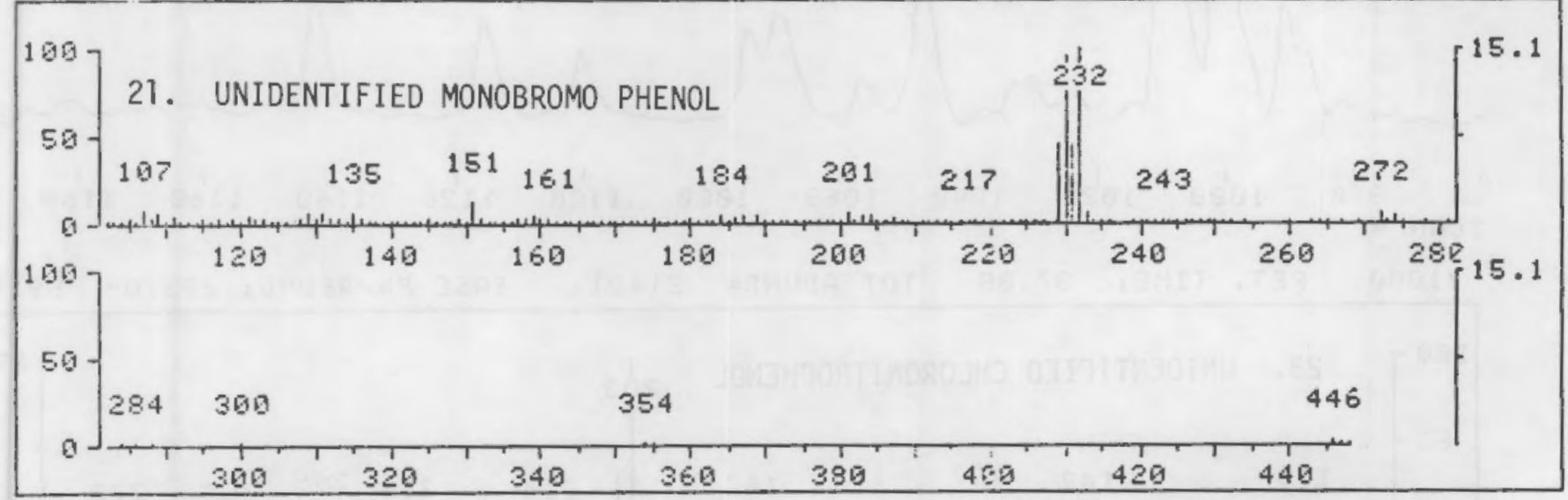

* 990 RET. TIME: 37.68 TOT ABUND= 14702. BASE PK/AEUND: $232.0 / 2435$.

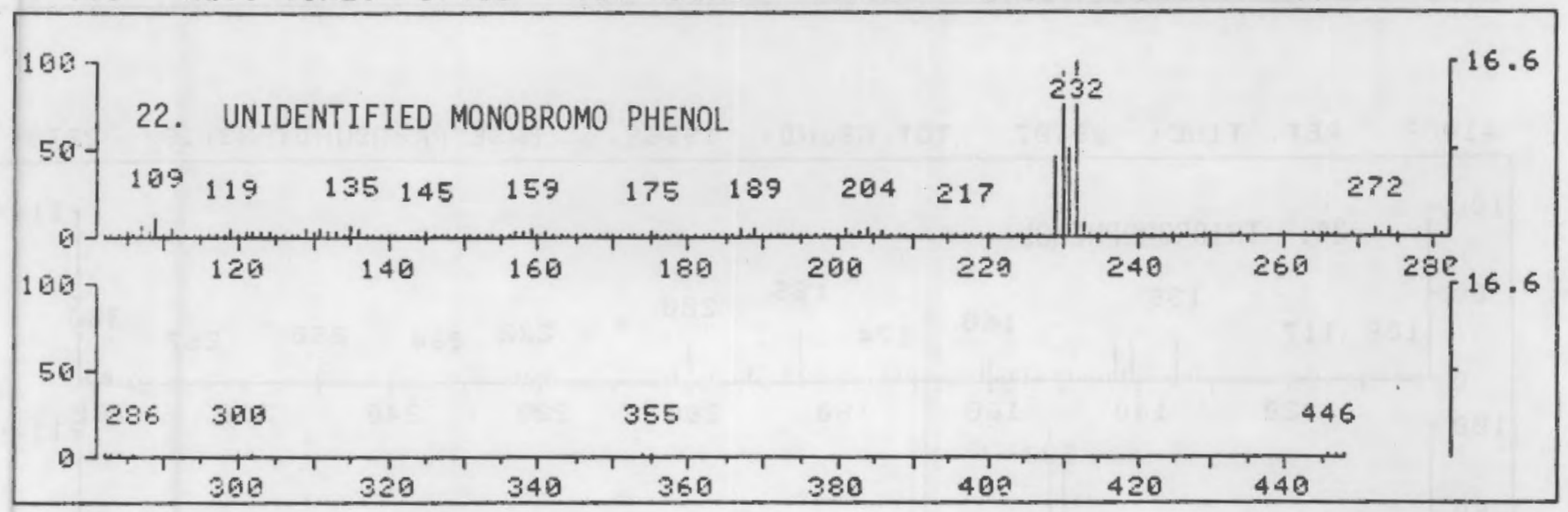


TROJANA FHENOLS XAD 3A TOWER $M 162-450, P D 3, T 5, S D 13, E M 2800$

$\Gamma^{\times} \quad 1.0$
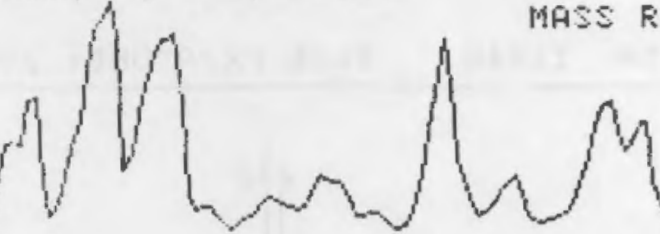

2482 SENAS $(24$ : STANS, 6.08 MINSI

FRH 8092 , CRR MASS RAHGE: $161.0,449.3$ TOTAL ABUHD $=9734246$.

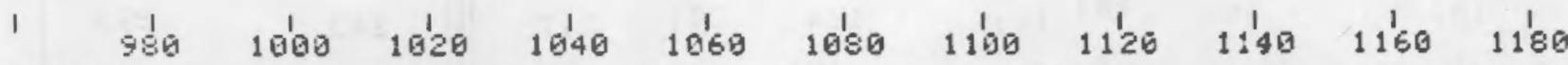
SCAN \#

1000 RET. TIME: 37.85 TOT AEUHL= 21421. EASE FK/ASUHD: 293.0, 5919.

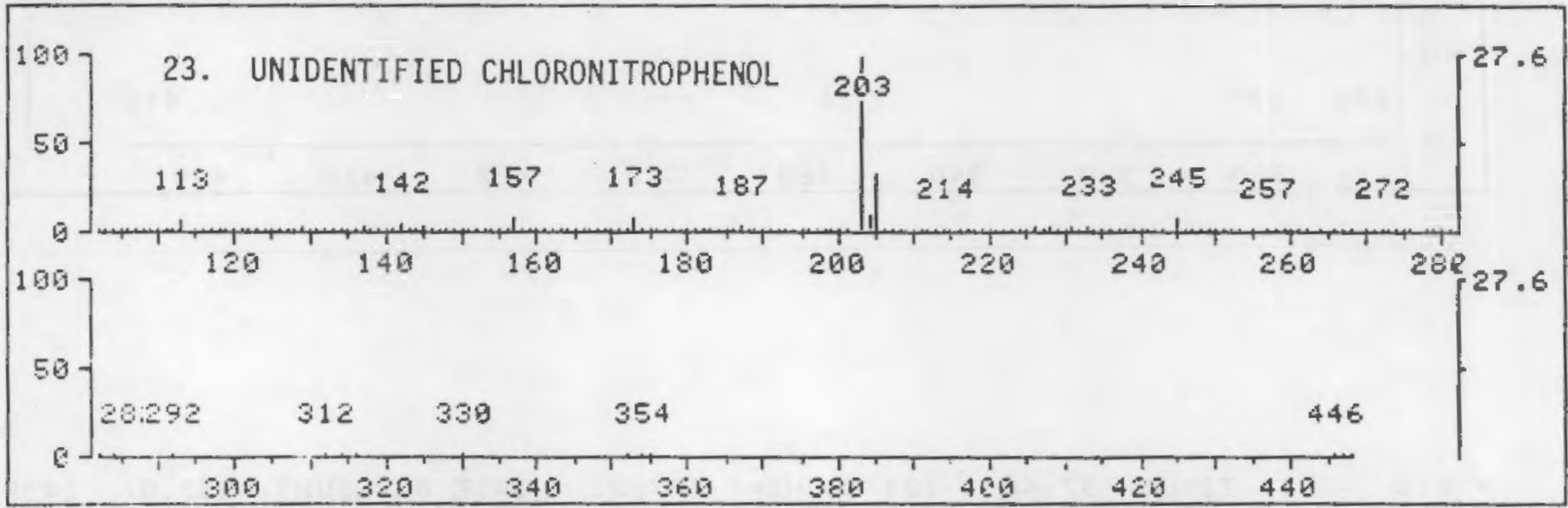

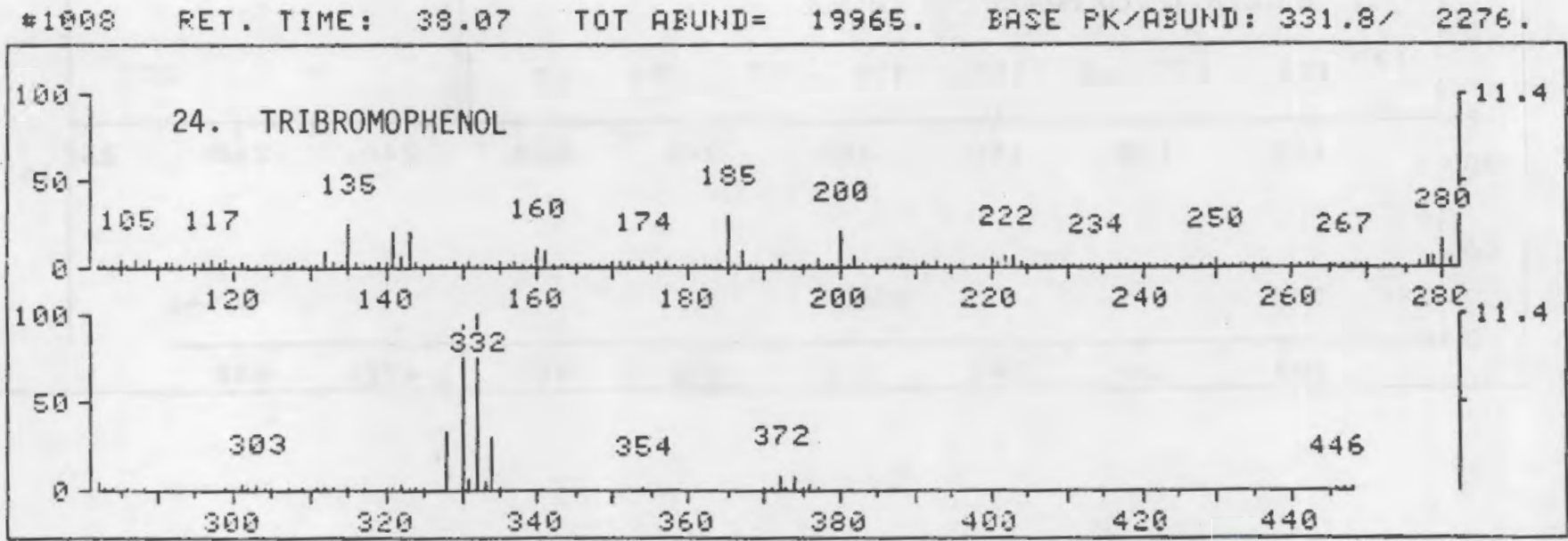


\#1101 FET. TIME: 40.46 TOT ABUND= 11368. EASE PK/FBUND: 249.0/ 1110.

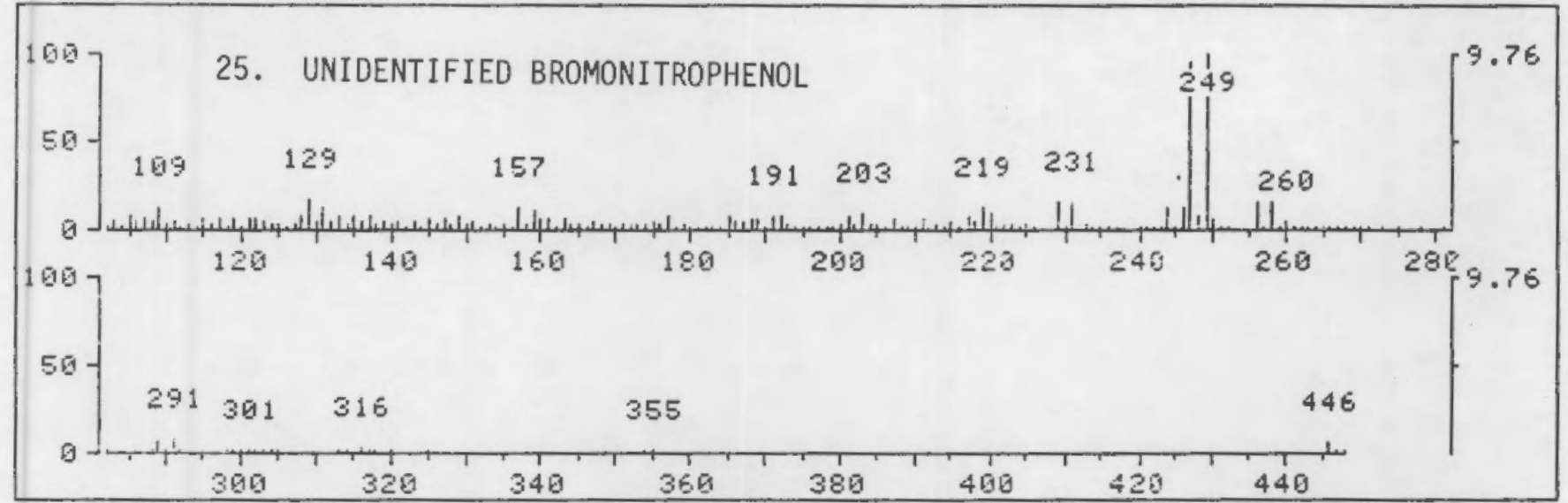

\#1116 RET. TIME: 49.78 TOT AEUHII= 14465. BASE PK/ABUND: 265.9/ 1516.

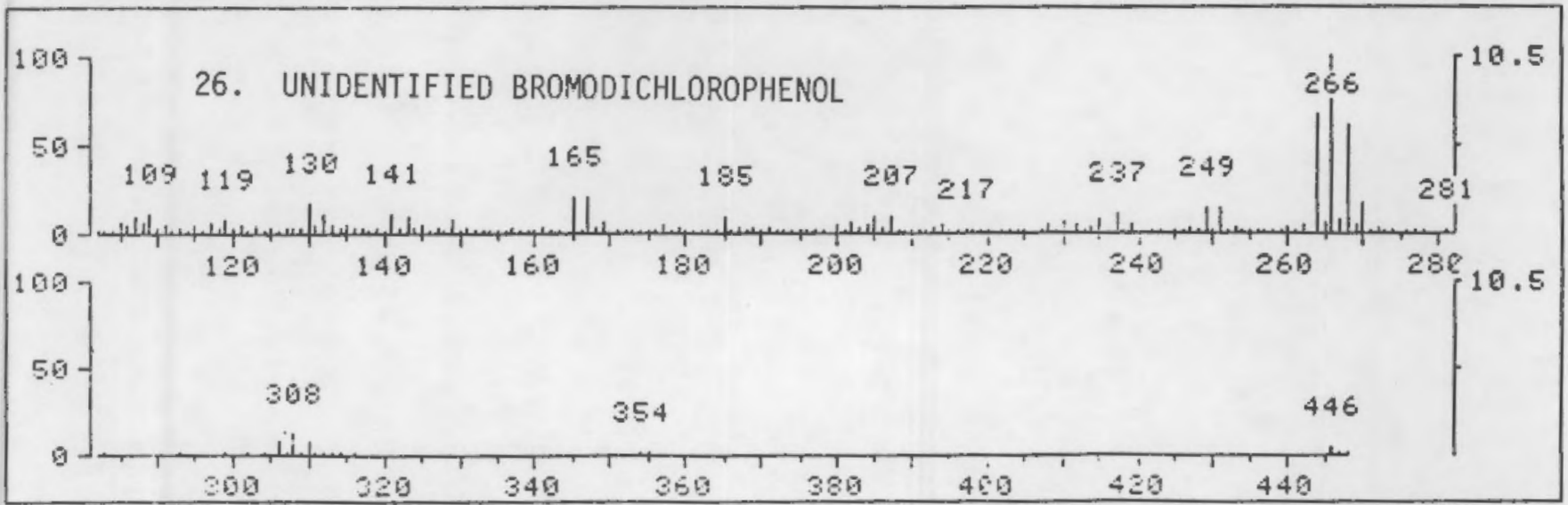




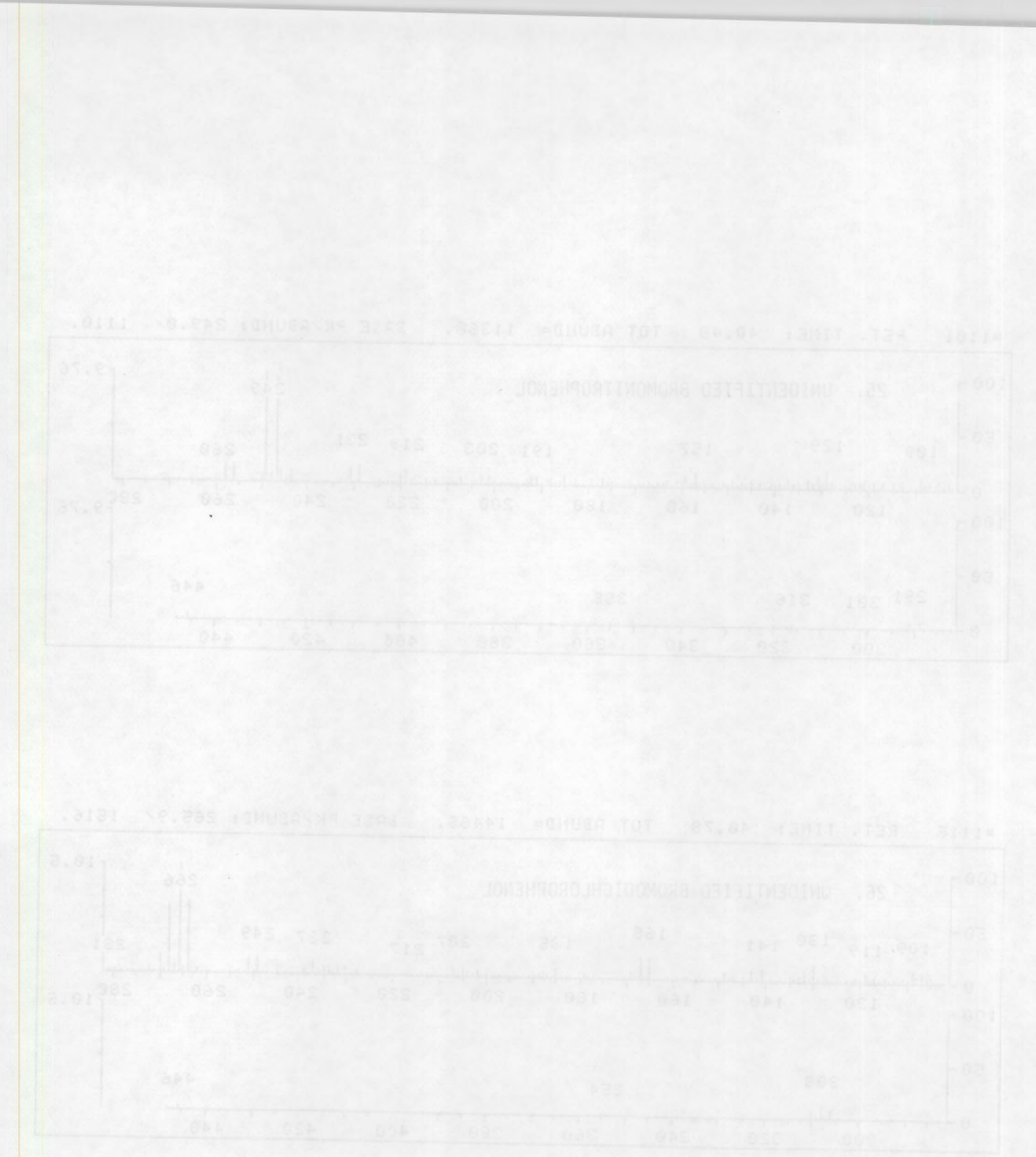




\begin{abstract}
APPENDIX D
SPECTRA OF HALOGENATED BASE-NEUTRAL COMPOUNDS FOUND IN CHLORINATED POWER PLANT WATER AND NOT FOUND IN NONCHLORINATED WATER. ALSO: SPECTRUM OF NITRO PHENOL
\end{abstract}


TWO BASE-NEUTRAL HALOGENATED COMPOUNDS FOUND IN MILLSTONE DISCHARGE: THE COMPOUND FOUND AT RT $=11.02$ IS DIBROMOIODOMETHANE; THE OTHER, RT $=28.98$ IS NOT IDENTIFIED.

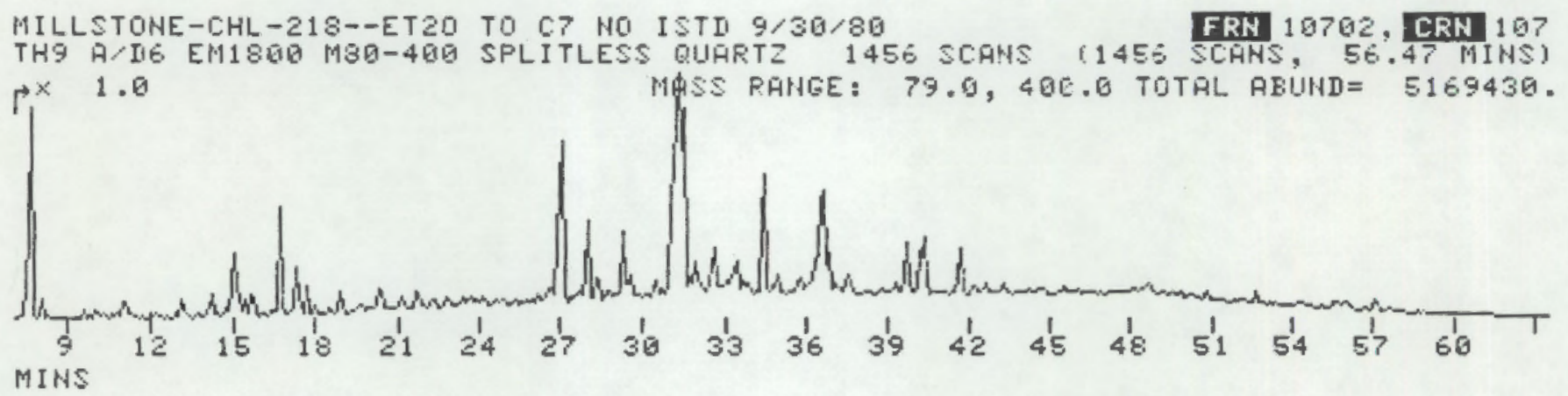

* 105 RET. TIME: 11.02 TOT ABUND= 3033. BASE PK/ABUHD: 173.0 . 642.

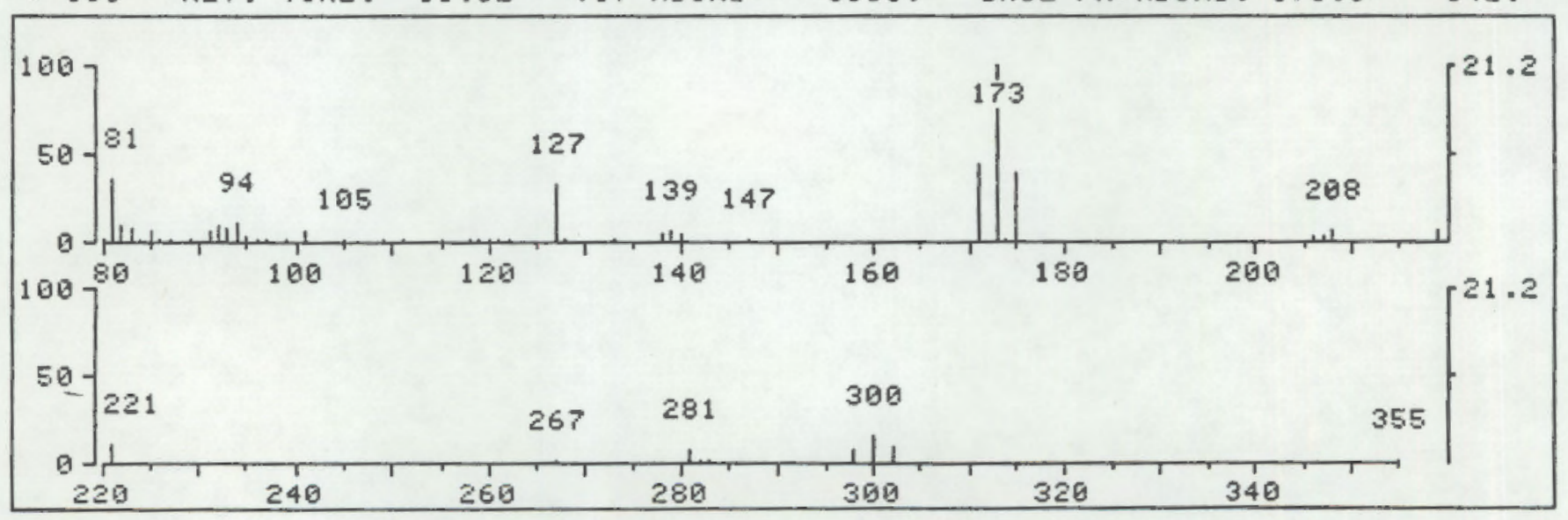

* 569 RET. TIME: 28.98 TOT ABUND= 4277. BASE PK/ABUND: 95.2/ 116.

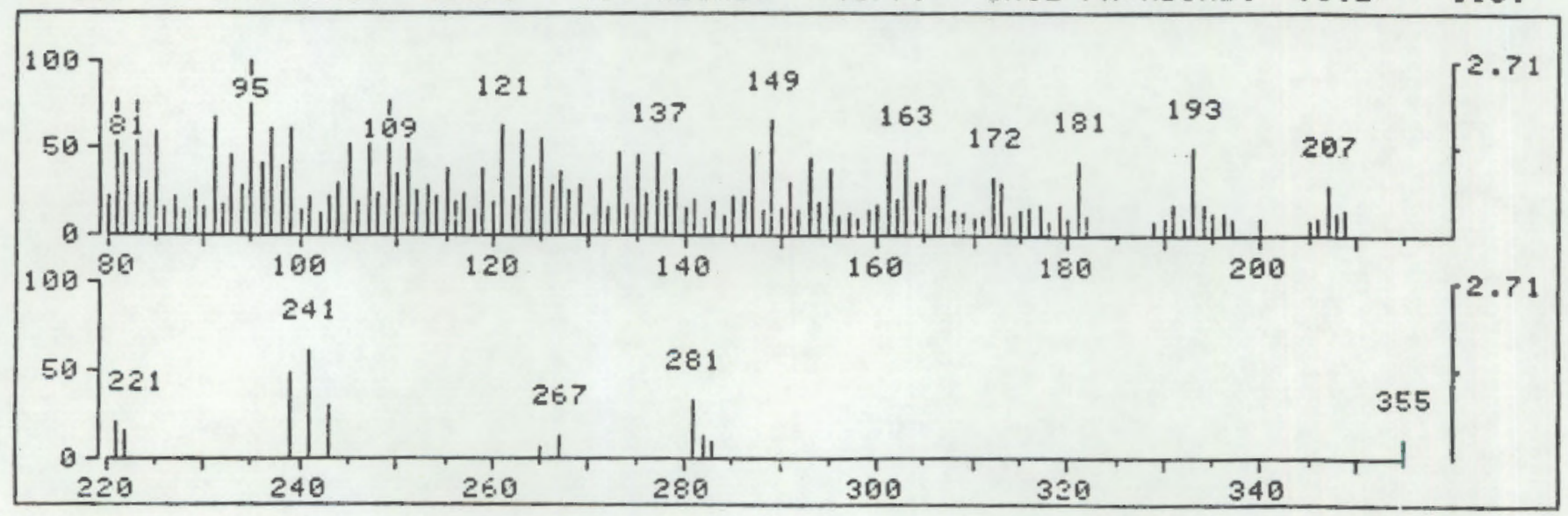


THIS BASE-NEUTRAL COMPOUND FOUND IN THE ARKANSAS COOLING TOWER IS DIBROMOIODOMETHANE. THE OTHER COMPOUNDS SHOWN IN THE FOLLOWING THREE PAGES ARE UNIDENTIFIED BROMINATED COMPOUNDS.

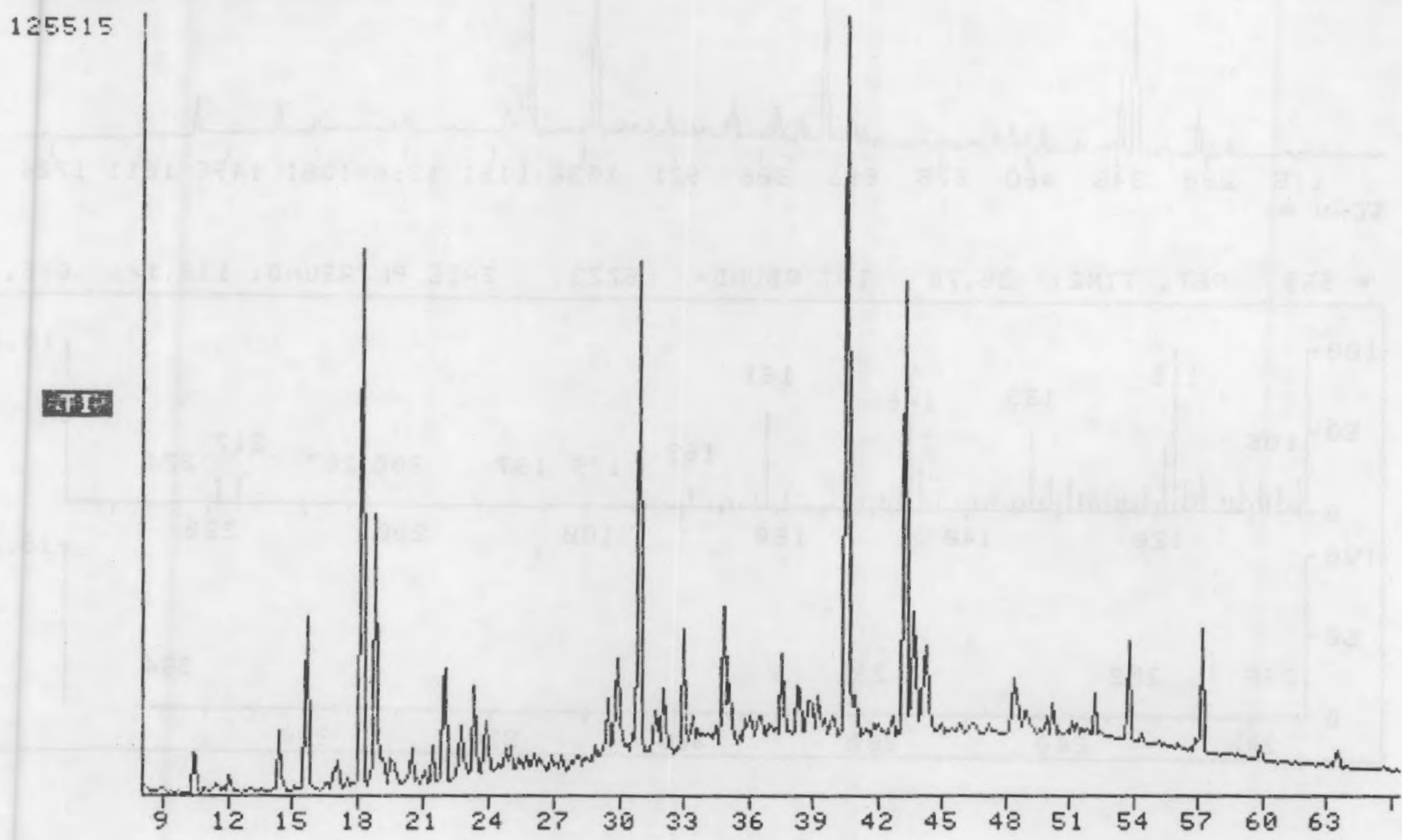

* 128 FET. TIME: 12.07 TOT ABUND= 1848. RASE PK/ABUND: 172.9/ 361.

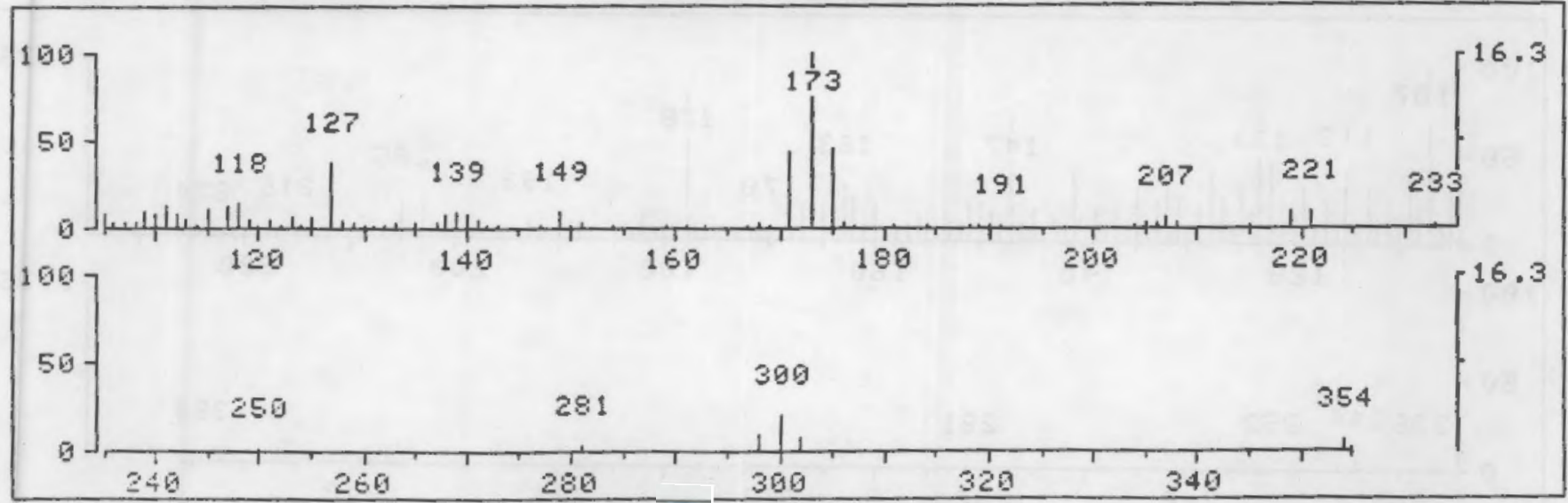


AFKENSATS-IJNITEZ-22E-SIL GEL CUTS $1 \% 2$ COHEIHED

FRH 22321, CRN 293

THT ATDS EM2400 H105-460 3977-76 2-09-81 1825 SEANS (1825 SCANS, 58.48 MINS) p. $: .9$

MASS RFNEE: $104.3,490.8$ TOTAL AEUND $=14251934$.

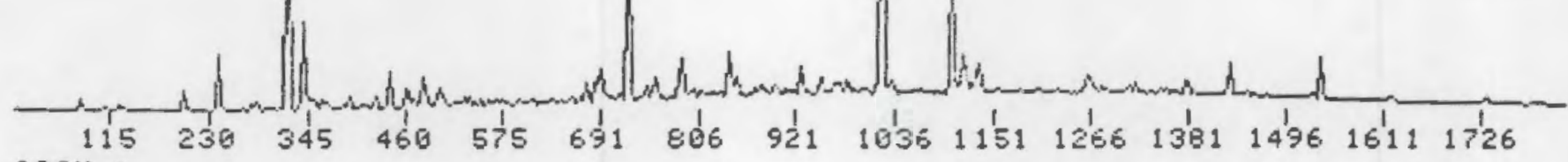
SCRN

* 559 RET. TIME: 25.73 TOT AEUHI = 6723. BASE PK/ABUHD: $116.1 / 685$.

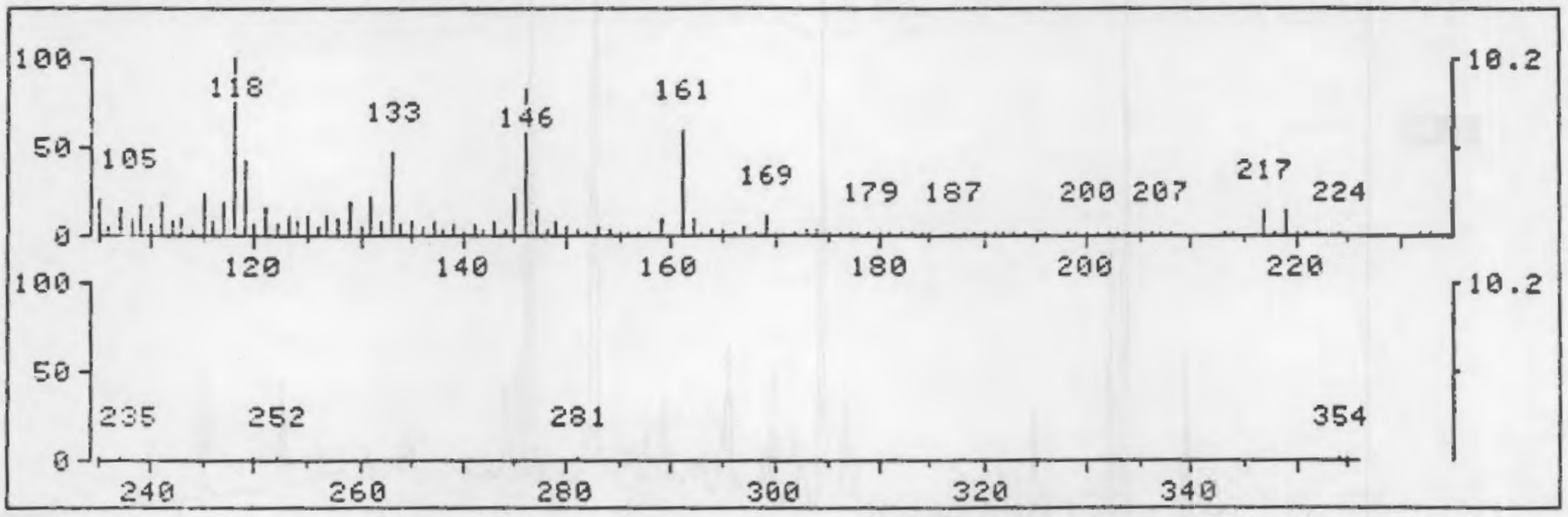

* 595 RET. TIME: 26.92 TOT ABUND= 6389. ERSE PK/ABUND: $107.1 / 369$.

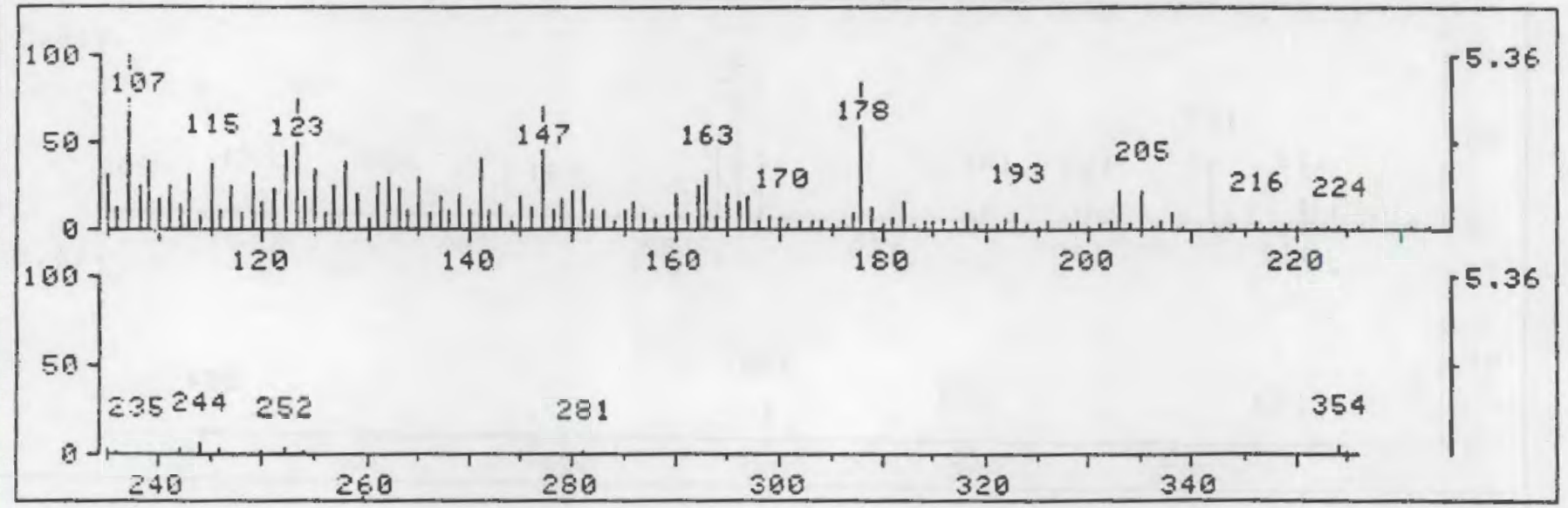


RRY.ANSAS-UNIT\#2-226-SIL GEL CUTS 1 \& 2 COMBINED

FRH. 22321 , CRN 203

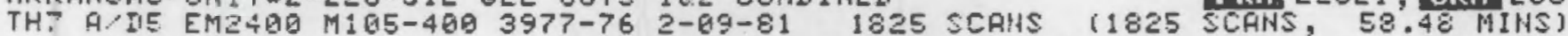

$+1.0$ MASS RANGE: $\mid 164.9,406.9$ TOTAL AEUND $=14251934$.

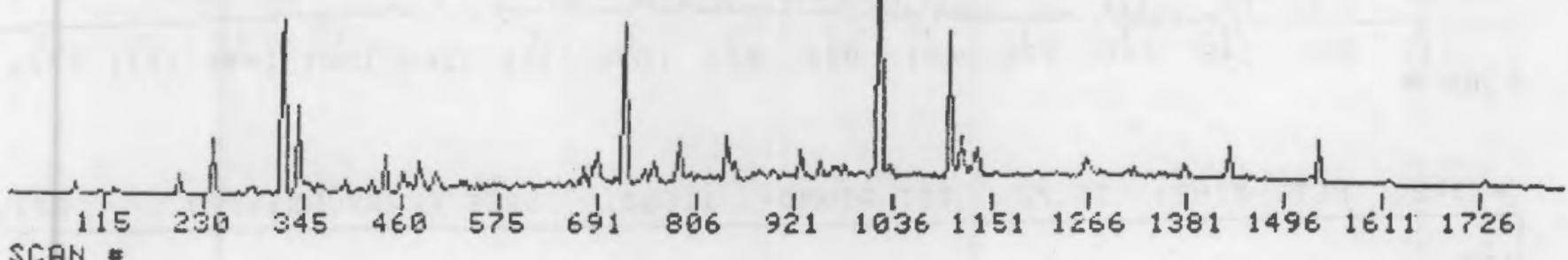
SCAN

* 864 RET. TIME: 35.52 TOT ABUND= 10261.

BRSE FK/ABUND: 109.1 , 282.
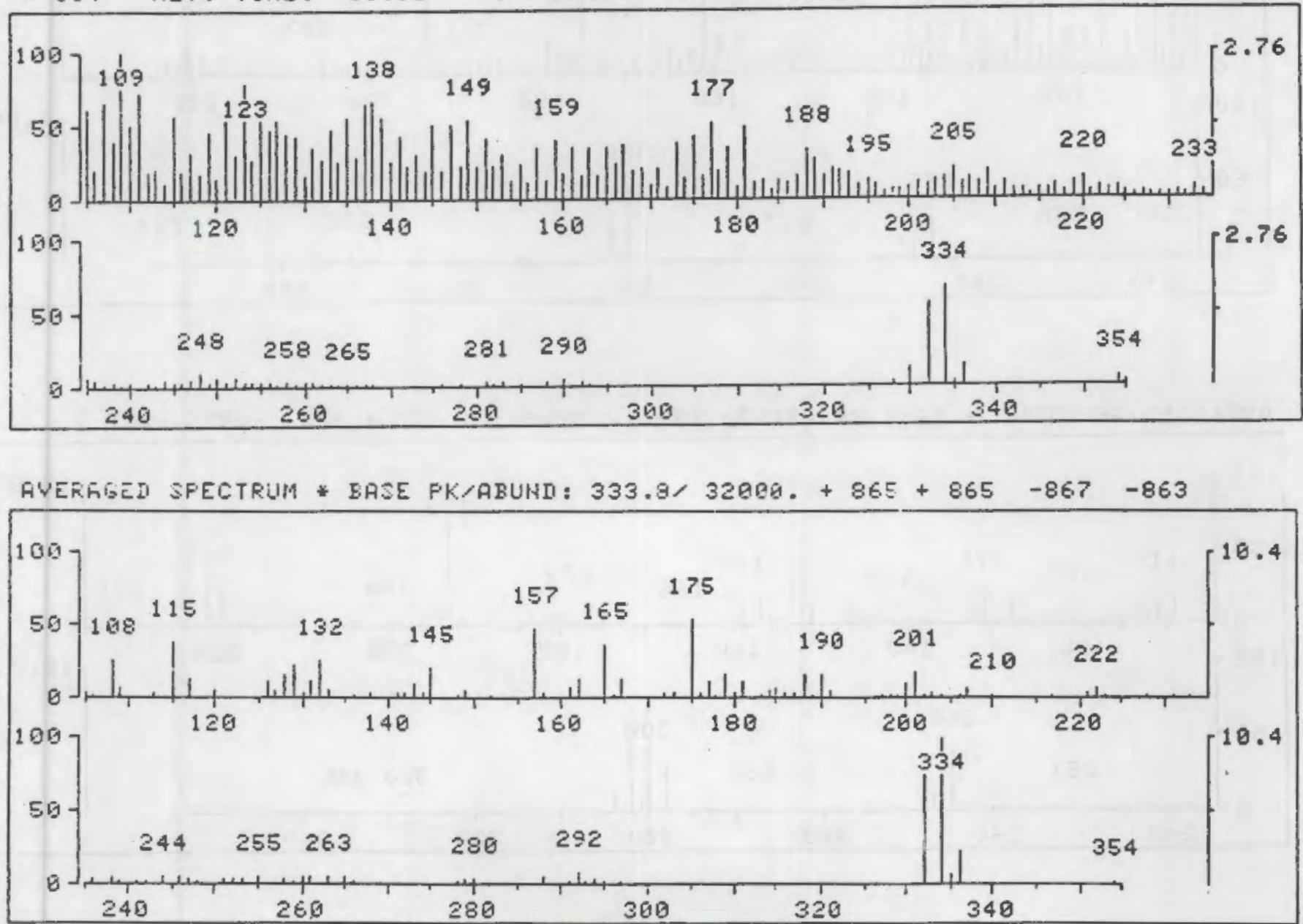
-AFKKANSAS-UNITW2-226-SIL GEL CUTS $1 \% 2$ COMBINED FRH 22321, ICRN 203 TH7 A IDS EM2400 M105-400 3977-76 2-69-81 1825 SCANS (1825 SCAHS, 58.48 MINS) $\Gamma^{\times} 1.0$ MASS RRHGE: $\mid 184.0,40.0$ TOTAL AEUNI $=14251934$.

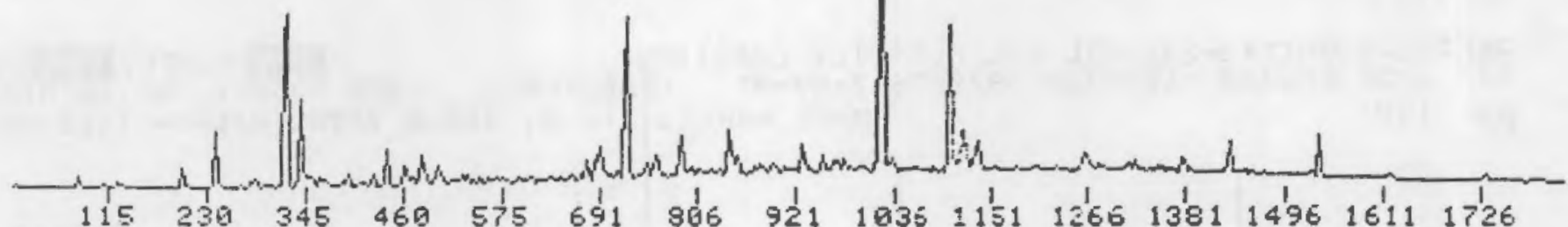
SCAN \#

- 872 RET. TIME: 35.77 TOT ABUND= 12532. EASE FK/RBUND: $193.1 / 501$.
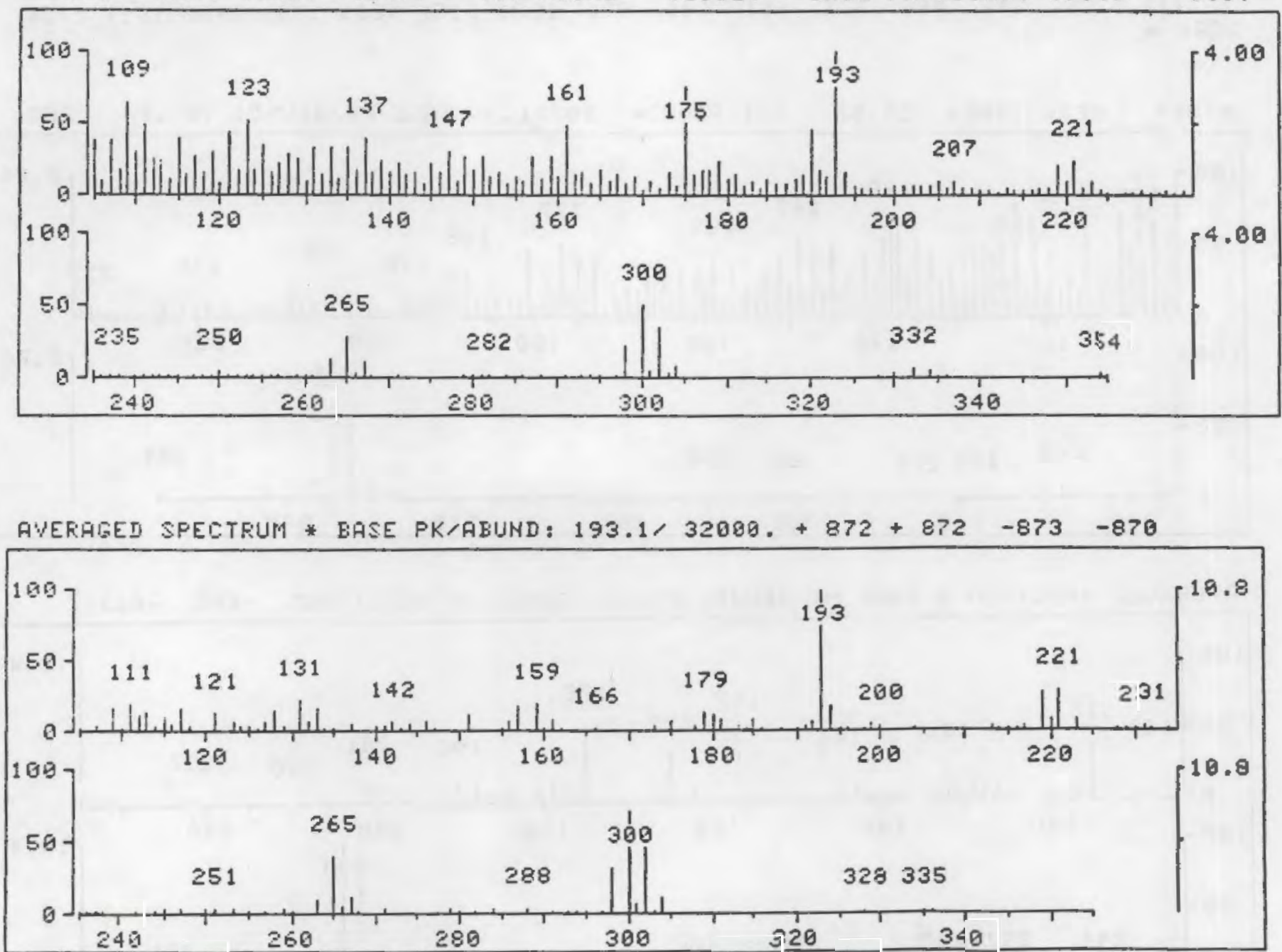


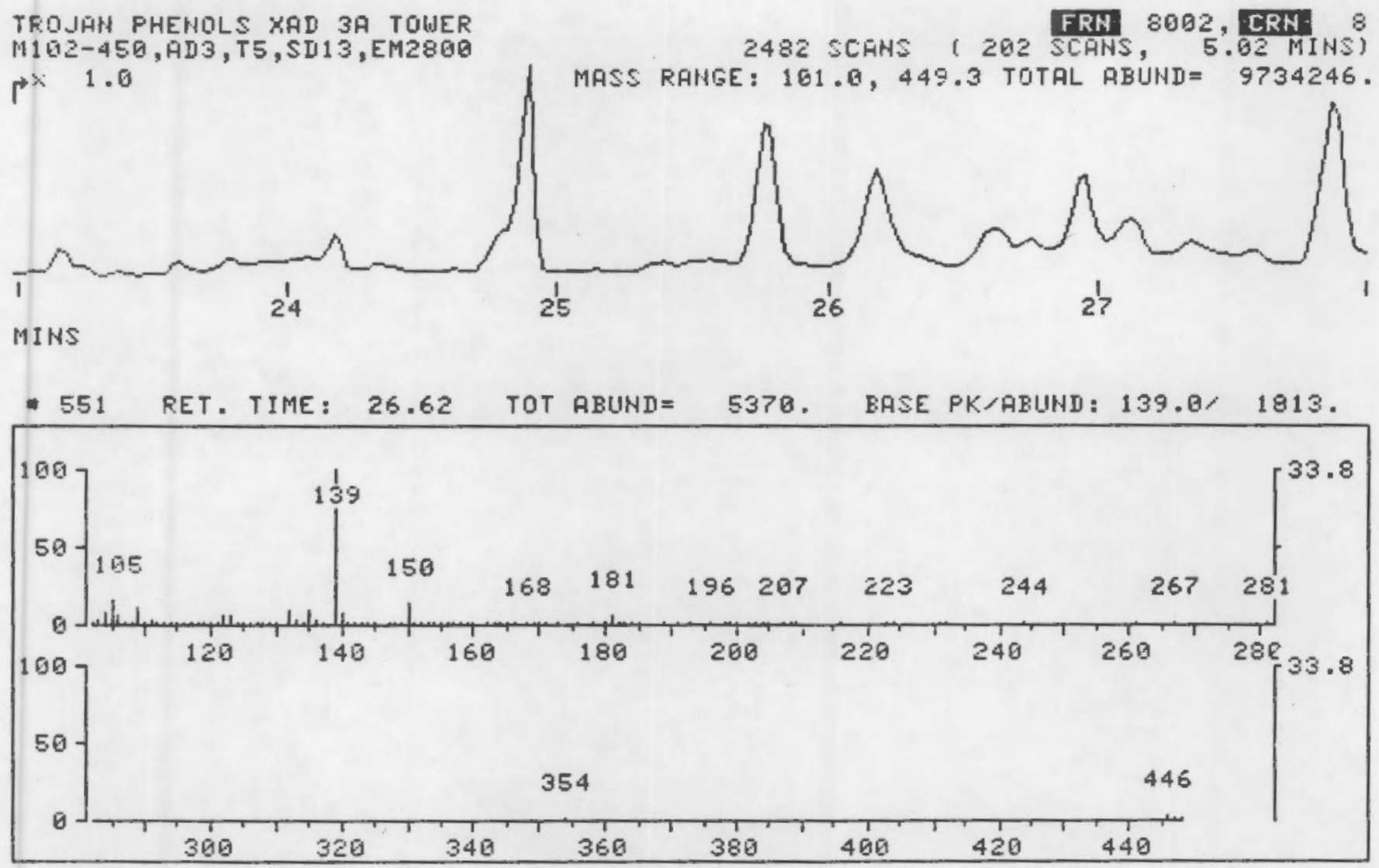

SPECTRUM OF NITROPHENOL, FOUND IN ALL INTAKE AND DISCHARGE WATERS EXAMINED. 


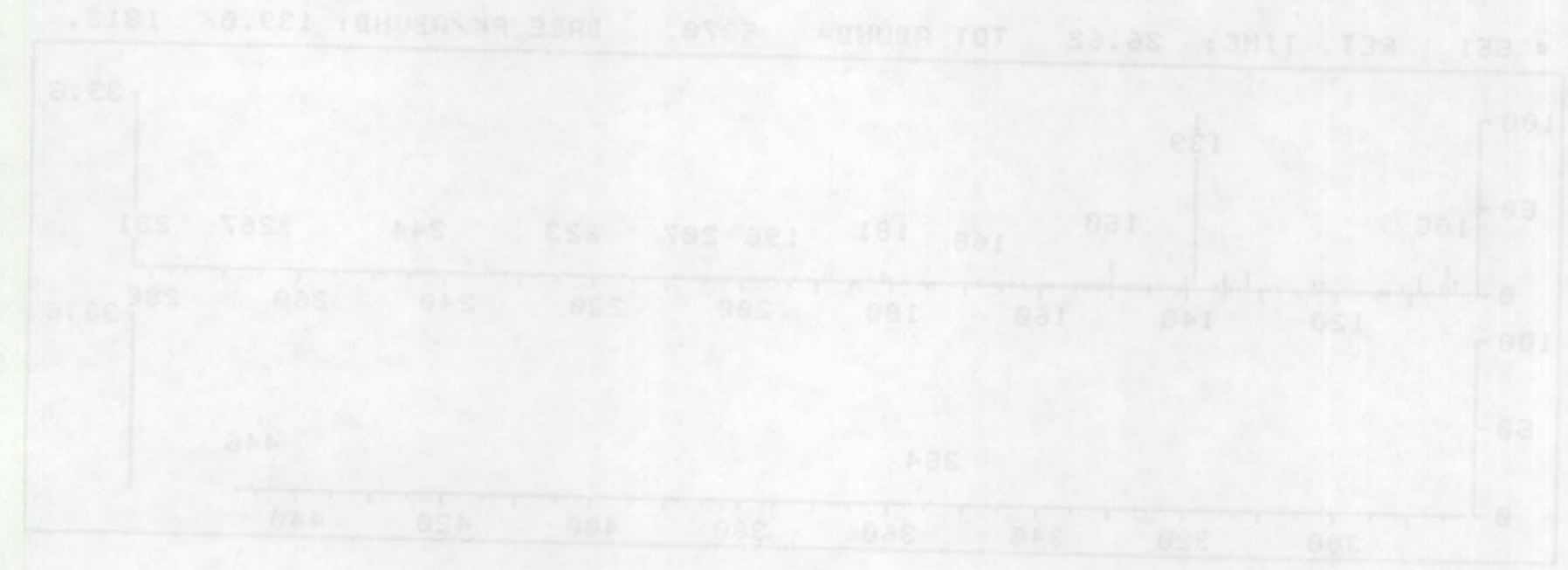




\section{DISTRIBUTION}

No. of

Copies

DFFSITE

NRC Division of Technical Information and Document Control Washington, D.C. 20555

2 DOE Technical Information Center

3 Dr. Phillip R. Reed Bob Samworth John C. Lehr U.S. NRC 7915 Eastern Avenue Silver Springs, MD 20901

Dr. Milton H. Lietzke P.0. Box $X$

Oak Ridge National Laboratory

Oak Ridge, TN 37830

Dr. John Lum

U.S.E.P.A.

401 M Street S.W.

WH552

Washington, D.C. 20460

2 Dr. Roy Nakatani

Dr. Quentin J. Stober

FRI WH-10

University of Washington

Seattle, WA 98195

Mike Buchman

NOAA

NOS/OAD N/OMS

Seattle Project Office

C15700

Seattle, WA 98115

Dr. William Renfro

Northeast Utilities Service

Environmental Program Dev.

P.D. Box 270

Hastford, CT 06101
No. of

Copies

Dr. Dale Swindle, Manager

Technological Analysis

Arkansas Power and Light Co.

Little Rock, AR 72203

Mr. Keith Young

Duane Arnold Energy Center

P. 0. Box 351

Cedar Rapids, Iowa 52406

Mr. Howard Rogers

Health Physics

Edwin Hatch Power Plant

Baxley, GA 31513

Mr. Gordon Rich

Portland General Electric Co.

P.0. Box 439

Rainier, OR 97048

Ms. Gerry Veldman

Palisades Nuclear Power Plant

Blue Star Highway

Covert, MI 49043

Ronald L. Raschke

U.S. EPA

S.E. Water Laboratory

Bailey Road

Athen, GA 30601

Nathaniel Barr

U.S. Department of Energy

OHER/ER E-201

Washington, DC 20545

Sylvia E. Barrett

The Metropolitan Water

District of Southern

California

700 North Moreno Avenue

La Verne, CA 91750 
No. of

Copies

Dorothy L. Bennett

Ill inois Environmental

Protection Agency

2200 Churchill Road

Springfield, IL 62706

Theodore I. Bieber

Department of Chemistry

Florida Atlantic University

Boca Raton, FL 33431

Scott D. Boyce

California Institute of Technology

EQL 314-40 Cal Tech

Pasadena, CA 91125

Herbert J. Brass

U.S. Environmental Protection Agency

Office of Drinking Water

5555 Ridge Avenue

Cincinnati, OH 45268

William A. Brungs

U.S. Environmental Protection Agency

South Ferry Road

Narragansett, RI 02882

Richard Bull

U.S. Environmental Protection Agency

Cincinnati, $\mathrm{OH} \quad 45268$

Dennis T. Burton

Johns Hopkins University

Applied Physics Laboratory

4800 Atwell Road

Shady Side, MD 20764

Joseph A. Cotruvo

U.S. Environmental Protection Agency

Office of Drinking Water

(WH-550)

401 M Street, S.W.

Washington, D.C. 20460
No. of

Copies

William P. Davis

EPA, Gulf Breeze Environmental

Research Laboratory

Route 1, Box 265-B

Wadmalow Island, SC 29487

James Fava

Ecological Analysts, Inc.

15 Loveton Circle

Sparks, MD 21152

Robert S. Grove

Southern California Edison Co.

P.0. Box 800

Rosemead, CA 91770

George R. Helz

Stanford University

Department of Geology

Stanford, CA 94305

Juraj Hostynek

The Clorox Company

7200 Johnson Drive

Pleasanton, CA 94566

Donald Johnson

Department of Env. Sci. and Engineering

School of Public Health

Roseau Hall

University of North Carolina at Chapel Hill

Chapel Hill, NC 27514

Robert L. Jolley

Oak Ridge National Laboratory

P.0. Box X

Oak Ridge, TN 37830

Arnold M. Kuzmack

U.S. Environmental Protection

Agency

Office of Drinking Water

(WH-550)

Washington, D.C. 20460 
No. of

Copies

Jack Mattice

EPRI

3412 Hillview Avenue

P.0. Box 10412

Palo Alto, CA 94303

Craig V. Seaman

Tennessee Valley Authority

1140 Chestnut Street Tower II

Chattanooga, TN 37401

\section{ONSITE}

50 Pacific Northwest Laboratory

RM Bean (35)

KE Byers

DW Glover

RN Lee

KM McFadden

DA Neitzel

TL Page

RG Riley

NM Sherer

Publishing Coordination (2)

Technical Information (5) 



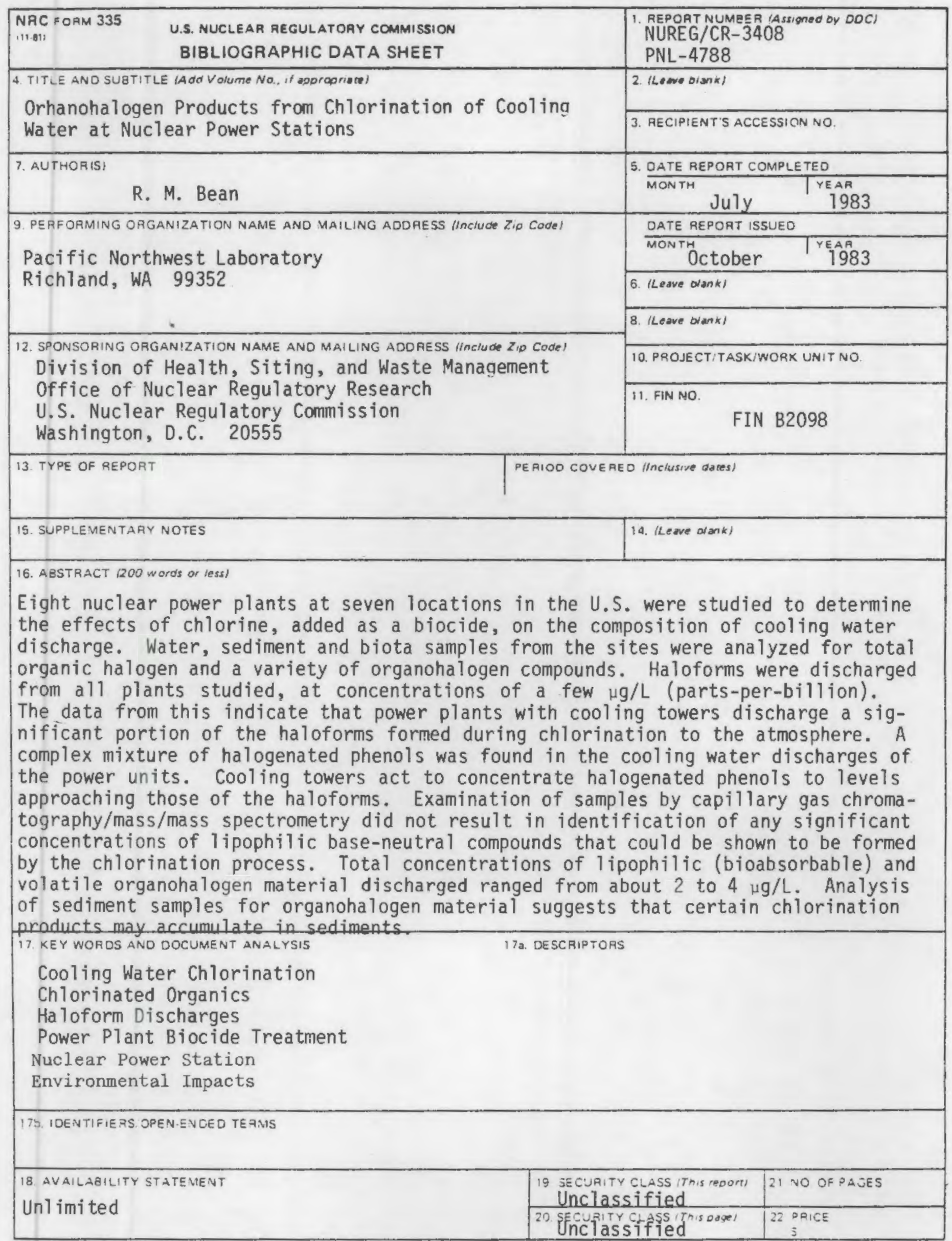

VAC FOAM 335 "11 211 


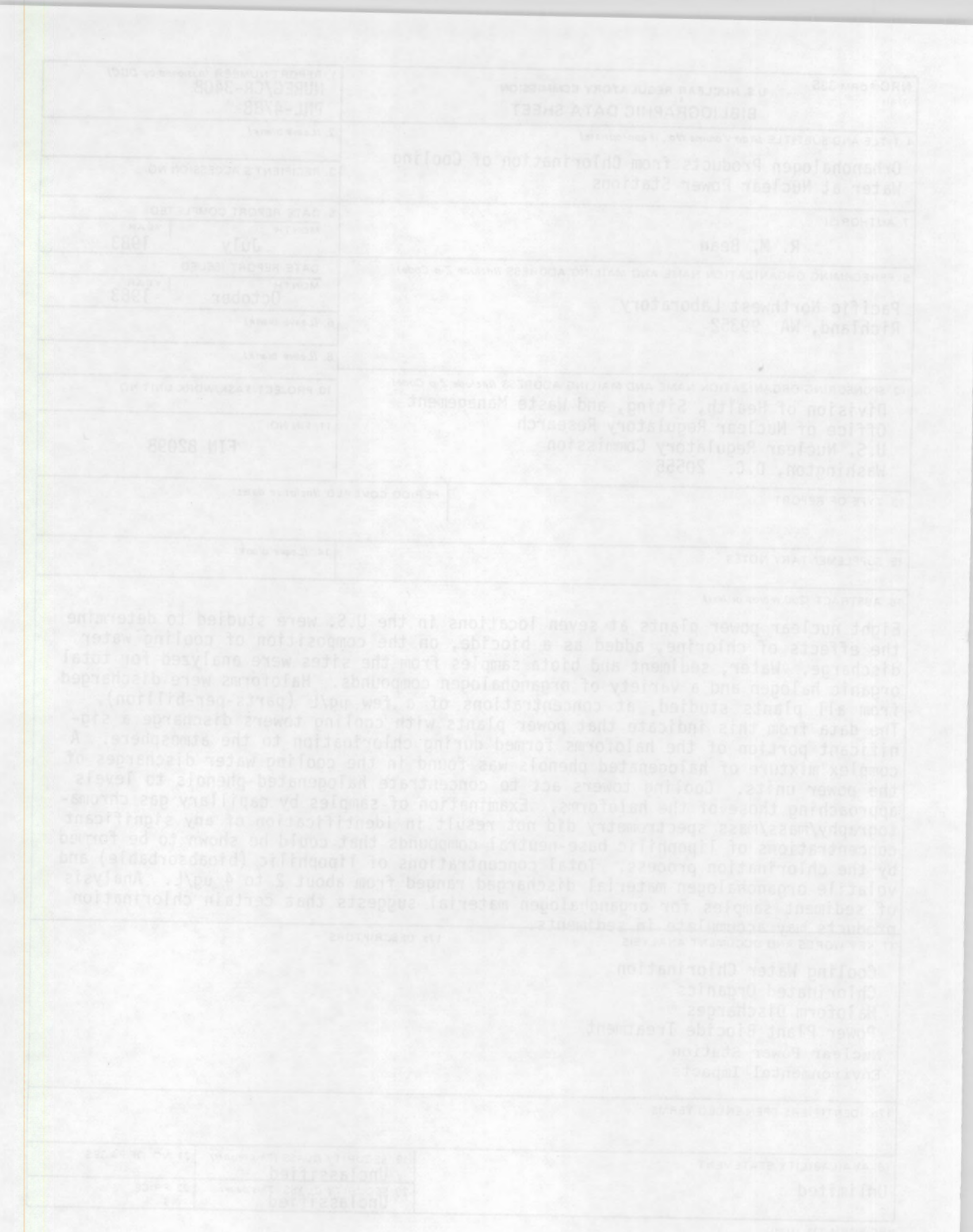

